\title{
Esperança equilibrista: cartografias de sujeitos que vivenciam o sofrimento psíquico em uma comunidade urbana
}

\author{
Bernadete Maria Dalmolin
}

Tese apresentada ao Programa de PósGraduação em Saúde Pública da Faculdade de Saúde Pública da Universidade de São Paulo para obtençăo do título de Doutora em Saúde Pública.

Área de Concentração Materno-infantil. Linha de pesquisa: Sociedade

Contemporânea e Saúde Pública.

Orientadora: Prof ${ }^{a}$. Dr ${ }^{a}$. Maria da Penha Costa Vasconcellos

São Paulo 


\section{Esperança equilibrista: cartografias de sujeitos que vivenciam o sofrimento psíquico em uma comunidade urbana}

Bernadete Maria Dalmolin

Tese apresentada ao Programa de PósGraduação em Saúde Pública da

Faculdade de Saúde Pública da Universidade de São Paulo para obtençăo do título de Doutora em Saúde Pública.

Área de Concentração Materno-infantil. Linha de pesquisa: Sociedade Contemporânea e Saúde Pública.

Orientadora: Prof ${ }^{a}$. Dr ${ }^{a}$. Maria da Penha Costa Vasconcellos

São Paulo 
Dedico este trabalho

Ao Matheus, Felipe, Elizandra e Jorge, fachos de luz em minha vida.

Aे todas as pessoas que vivem a esperança de encontrar novos caminhos na luta pela saúde e pela vida. 


\section{Agradecimentos}

Este, como todo o trabalho, é fruto de uma construção coletiva com o qual muitas pessoas e instituições contribuíram para que se pudesse chegar até aqui. Na impossibilidade de nomear todos que dela participaram, citarei alguns, na certeza de que, neles, por certo, estarão, de uma forma ou de outra, representados todos os demais.

A cada um dos sujeitos do estudo em particular e, suas famílias, que me acolheram, ajudando-me a compreender alguns "territórios", diante de tantos outros incompreensiveis.

À professora Maria da Penha Costa Vasconcellos, que me "contagiou" com seu jeito instigante e afetivo de partilhar seu grandioso saber, desde o mestrado, possibilitando-me percorrer trilhas até então inimagináveis na busca da construção do conhecimento. Sempre comprometida com nosso crescimento pessoal, não mediu esforços para encurtar a distância Passo Fundo-São Paulo e, também, olhar de perto o meu pedaço, mostrando toda a sua sensibilidade.

Ao Paulo Roberto Azeredo de Souza que me ensinou a descobrir diferentes facetas da vida, na esperança de ser uma estrela guia à outras pessoas que, como ele, vivem a experiência do sofrimento psíquico.

À professora Augusta Thereza de Alvarenga, querida amiga que compôs a "familia de São Paulo", acolhendo-me afetivamente e contribuindo na minha formação com sua delicadeza e cuidado.

Ao professor José Guilherme Magnani por ter me oportunizado conhecer um pouco da Antropologia Urbana através de suas obras e das suas aulas. Ao professor Rubens Adorno que também contribuiu desde a qualificação do projeto. À professora Sônia Barros e ao professor Paulo Amarante que estimularam esse trabalho com suas produções especificas e com as sugestões na pré-banca.

À Universidade de Passo Fundo e à Secretaria de Estado da Saúde do Rio Grande do Sul pelo esforço na qualificação dos seus profissionais.

Aos colegas da UPF e da $6^{a}$ Coordenadoria Regional de Saúde por carinhosamente assumirem parte do meu fazer para que eu pudesse cursar o doutorado.

Aos meus alunos, pelo estímulo para seguir nessa caminhada.

À Stella Maris, querida amiga que descobri no doutorado e "coirmã" de orientação que, mesmo distante, puxava-me para perto com seu jeito meigo e suave de encarar a vida.

À Lúcia, à Lili, ao Clademir, à Vanderléia, à Rê, à Miriam, ao Hélio, à tia $l g$, fontes de afeto com quem sempre pude dividir sonhos, angústias, projetos...

À Cleide pela delicadeza e afeto na revisão do texto. 
À Vilma e Marlene, companheiras inseparáveis que, com muita paciência souberam partilhar comigo essa nossa história comum, colaborando inúmeras vezes com suas reflexões, mas, especialmente, por serem guardiãs dos afetos e sinalizadoras de que, na vivência de nossas redes afetivas, a vida se torna mais plena.

À minha mãe, batalhadora, grande mulher, que me ensinou que a dignidade é algo que se constrói em cada minúscula ação e a cada dia da nossa existência.

À minha grande familia que me apoiou de forma incondicional, mostrando sempre que o amor e a ajuda mútua contribuem para o crescimento de todos. Familia que se orgulha por essa conquista, mesmo tendo que abdicar da minha presença em muitas situações. Em especial aos meus filhos Matheus e Felipe que me enchem de vida com suas descobertas e seus carinhos, à Elizandra, filha do coração, que veio enriquecer minha vida, ao Jorge, meu grande companheiro, presença fundamental e permanente fonte de amor, afeto, desafio, incentivo e respeito.

Enfim esse ponto final é coletivo, meu muito obrigada. A TESE acabou, VIVA todos nós. 


\section{RESUMO}

ESPERANCCA EQUILIBRISTA: cartografias de sujeitos que vivenciam o sofrimento psíquico em uma comunidade urbana

Este estudo teve por objetivo analisar as experiências de pessoas que vivenciam o sofrimento psiquico nas dimensões da cidade. A metodologia adotou contribuições da etnografia e tomou como instrumentos: entrevistas e documentos - oficiais, de jornais e do sistema de informações do SUS. Para a compreensão da dinâmica cotidiana desse grupo social, partiu-se de um bairro da cidade de Passo Fundo/RS, buscando apreender quem os moradores deste bairro reconheciam como "doentes mentais". A investigação revelou a existência de lógicas de percepção diferentes sobre a pessoa adoecida mentalmente, possibilitando a leitura de duas cartografias: a cartografia institucional e a cartografia cotidiana do bairro, cartografias essas que se aproximam e se entrelaçam em muitos momentos da vida. Nas experiências desses moradores "doentes" é possivel encontrar um sujeito em interação com o local, desejante, buscando o exercicio da cidadania, mesmo com os tropeços e desencontros sofridos pela sua diferença. Quando as instituições de saúde mental e o aparato que se constitui em torno delas fazem a mediação com esses sujeitos, as relações institucionalizam-se de modo a deixar pouco do que é propriamente seu, dos fluxos existenciais de um sujeito que necessita de constantes suportes terapêuticos para expandir as possibilidades de vida. Ao contrário, nesses espaços institucionais a produção subjetiva sofre uma captura, salientandose no estabelecimento das terapêuticas aquilo que pode ser regido pela norma e pelos padrões definidos a priori, deixando marcas profundas de privação de direitos fundamentais. Nas trajetórias dos protagonistas, destacam-se o investimento de tempo em relações intensas e de grande valor social, cultural e afetivo, refletindo a luta para evitar perdas advindas do adoecimento, a associação aos códigos do lugar, a manutenção e o fortalecimento dos vínculos sociais e a busca de autonomia e liberdade para circular e decidir sobre suas vidas. Essas "invenções" singulares nos espaços da cidade e o contexto de relações que elas abarcam, sinalizam a urgência de outros modos de cuidar dessas pessoas que mantém a esperança equilibrista de viver e construir novos processos de subjetivação.

Descritores: saúde mental, cultura local, políticas públicas. 


\section{ABSTRACT}

\section{ACROBAT HOPE: mapping of subjects who face psycho suffering in an urban community.}

This study has been performed to analyze people's experience with psycho suffering in urban dimensions. The method has used ethnographic contributions and interviews, official documents, newspapers and health system records. In order to understand the everyday dynamic of this social group, we have taken a suburban area in Passo Fundo-RS as a starting point, in an attempt to determine who would be considered mentally disabled by locals. The research pointed to different perceptions of who the mentally disabled people were, making it possible to determine two distinct mappings: the institutional mapping and the everyday mapping of the area, both of them having a close relation in many moments of life. Taking into account the sick local's experiences, it is possible to find a subject who interacts with the place, a person who expresses his or her wishes in an attempt to practice his citizenship, in spite of the differences imposed by his condition. When the mental institutions and all the process which involves them, make the mediation with these subjects, the relationship is institutionalized in a way it maintains very little of its own, of a subject's existence which needs a permanent therapeutic support to widen his life possibilities. On the other hand, in these institutionalized environments the subjective production is reduced, emphasizing what can be determined by the rule and by the previously determined patterns, deeply marking the lack of fundamental rights. In the subject's track, it is notoriously observed the time effort to maintain strong relationships which have a great cultural, social and emotional value, reflecting the subject's effort to prevent losses caused by the disease. It also reveals integration with local codes, the need to maintain and strengthen social links and the search for independency and the right to take decisions about their own life. These particular attempts within the urban boundaries and the context they refer to, point to an urgent need to take care of these people who keep hoping they can lead a better life and build themselves new subjective processes.

Descriptors: mental health, local culture, public policies. 


\section{SUMÁRIO}

INTRODUÇÃO INICIANDO O DESENROLAR DA TRAMA 1

Os primeiros enlaces entre pesquisados e pesquisador 4

CAPÍTULO I ATENÇÃO A SAÚDE MENTAL EM PASSO FUNDO: 17

historiando a organização dos serviços de saúde mental

CAPITULO II A CONSTRUÇÃO DE UM CAMINHO METODOLÓGICO 41

2.1 A escolha do caminho metodológico 41

2.2 A contribuição da antropologia na compreensão teórica do objeto $\quad 44$

2.3 Ponto de partida da pesquisa: o bairro Vera Cruz 49

2.4 A trilha seguida na construção da pesquisa 62

CAPITULO III O SOFRIMENTO PSIQUICO e suas múltiplas facetas $\quad 70$

3.1 A Saúde mental enquanto processo 71

3.20 sofrimento psíquico pelo campo psi 75

3.3 Através da psiquiatria basagliana o encontro de outros lugares para a 98 pessoa em sofrimento psíquico

3.4 A dimensão antropológica da saúde/doença 103

3.5 A complexidade do 'problema mental': uma trama que liga e religa 109

CAPÍTULO IV CARTOGRAFIAS DO COTIDIANO 115

4.1 Da cartografia oficial à cartografia do bairro: o ponto de vista dos 115 seus moradores

4.2 As trajetórias dos protagonistas $\quad 125$

4.2.1 Uma travessia de resistência a um jeito dominante $\quad 130$

$\begin{array}{ll}\text { 4.2.2 No drible entre a liberdade e a captura } & 137\end{array}$

4.2.3 Entre a casa e seus interlocutores imaginários $\quad 148$

4.2.4 A crise e as referências do território $\quad 151$

4.2.5 Um link com os de fora $\quad 155$ 
5.1 A primeira internação: um batizado de longa peregrinação pelos serviços de saúde

5.2 A "caixa de Pandora" dos serviços de atenção à saúde mental

5.2.1 Entre a familia e a instituição de saúde: o 'endereçamento' dado aos sujeitos que vivenciam o sofrimento psiquico

5.2.2 A 'acolhida' ao sujeito ou o recrudescimento da falta de liberdade?

5.2.3 Resistindo e protagonizando espaços: a busca de singularização

5.2.4 O retorno ao Hospital como álibi à falta de outros recursos

170

170

180

183

189

CAPÍTULO VI A METAMORFOSE DO SINGULAR AO PLURAL 198

6.1 A promotoria e a defensoria pública como estratégias de acesso à rede oficial de saúde e de ampliação de direitos humanos

$6.2 \mathrm{Na}$ mídia, outros pactos..., a lembrança de que uma determinada prática precisa "sobreviver"

ALGUMAS CONSIDERAÇOES: entrelaçando novamente a trama

REFERÊNCIAS

ANEXOS

Anexo 1 - Termo de consentimento esclarecido 


\section{LISTA DE FIGURAS}

Mapeamento dos serviços de saúde do municipio de Passo Fundo/RS I

Mapa do Rio Grande do Sul II

Mapa do município de Passo Fundo/RS II

Vista parcial da rua São Sebastião - Bairro Vera Cruz, Passo III

Fundo/RS

Vista parcial da rua Santana - Bairro Vera Cruz, Passo Fundo/RS III

Construções típicas do bairro Vera Cruz, Passo Fundo/RS IV

Crianças jogando bola no final da tarde. Rua Uruguaiana - Bairro Vera IV

Cruz, Passo Fundo/RS

"Beira-trilho" - Grande Vera Cruz, Passo Fundo, RS IV

Mapeamento das trajetórias de João-de-Barro V

Mapeamento das trajetórias de Beija-Flor $\quad$ VI

Mapeamento das trajetórias de Pomba-Rola VII

Mapeamento das trajetórias de Sabiá VIII

Mapeamento das trajetórias de Bem-Te-Vi IX

Judiciário diz que gerencia a saúde e MP entra com ação contra o $\quad X$ governo. Jornal Diário da Manhã

Área da saúde lidera demandas da Defensoria. Jornal Diário da Manhã X

Hospital Bezerra de Menezes realiza campanha para enfrentar XI

dificuldades. Jornal Diário da Manhã.

Hospital Bezerra de Menezes vai receber recursos da Secretaria da XII

Saúde do Estado. Jornal Diário da Manhã.

Comunidade faz campanha e ajuda o hospital. Jornal Zero Hora. XII

Doações mudam a situação do Hospital Psiquiátrico Bezerra de XIII Menezes. Jornal O Nacional.

Faltam leitos no Hospital Psiquiátrico. Jornal O Nacional. XIV

Cerca de 100 pessoas por mês aguardam internação no Hospital XIV

Psiquiátrico Bezerra de Menezes. Jornal Diário da Manhã. 


\section{INTRODUÇÃO - INICIANDO O DESENROLAR DA TRAMA}

As inquietações e aflições cotidianas vividas como profissional de saúde e como professora da Universidade de Passo Fundo foram as fontes inspiradoras deste trabalho, pois despertaram em mim sentimentos diversos. Entre eles, o sentimento de impotência em lidar com determinadas situações de pessoas que convivem com o sofrimento psíquico e que procuram os serviços de saúde mental, e o desejo de desenvolver práticas terapêuticas mais adequadas às necessidades desses sujeitos.

Ouvir expressões como: não dê muita conversa, ele é manipulador, assim você mobiliza o paciente, não fique muito tempo com ele, esse é freguês antigo, recorrentes na convivência com colegas e ou, na observação e contato com outros serviços causavam-me desconforto.

De outro lado, as manifestações de súplica dos "usuários", seus gritos e internações indesejadas, suas fugas e retornos, suas intermináveis caminhadas de um lado a outro do corredor do hospital, suas expectativas de alta e suas expressões na saída desses locais denunciavam que algo não ia bem. Além disso, a tradição de escolha por fortes mecanismos de contenção (através de normas impostas pela instituição numa relação de dominação, medicalização ou contenção fisica) e uma intervenção centrada quase que exclusivamente nos sintomas, onde o sujeito e sua subjetividade são, via de regra, desconsiderados reforçaram meus sentimentos, motivando-me a olhar mais apuradamente, as contradições de um modelo de atenção ${ }^{1}$ à saúde mental que não me satisfazia mais como profissional de enfermagem na área de saúde mental. Essas constatações iniciais, relativas a uma forma de compreensão e organização do sistema de atenção, também são minhas na medida em que esse processo não se

\footnotetext{
1 O termo "modelo de atenção" é utilizado aqui, para designar um conjunto de serviços e práticas que foram se constituindo com o objetivo de equacionar a problemática da saúde mental, problemática esta que se constrói sobre determinadas concepções do processo saúde-doença mental.
} 
encontra fora do meu campo de formação e ação profissional. De fato, a enfermagem, historicamente, tem se pautado pelo estabelecimento de um fluxo de serviços balizado, predominantemente pelo controle e pela disciplina ${ }^{2}$.

Foram muitas as tentativas de mudança no campo da saúde mental nos últimos anos, mas, apesar de toda a orientação e legislação vigentes, a realidade psiquiátrica do municipio em questão parece ter se alterado pouco no mesmo periodo. Os elementos, por vezes contraditórios, de conceber e organizar a saúde mental no município, denotam a complexidade de mudança desse processo social, apontando uma direcionalidade na prática cotidiana, que me chamou a atenção, de modo especial, enquanto profissional que desenvolve atividades acadêmicas nos serviços de saúde.

Se, por um lado, podemos reconhecer que as alterações dos serviços especializados não deram conta de aprofundar e explicitar mudanças mais radicais, por outro, os individuos, suas familias e a própria comunidade buscam, em seu cotidiano social, responder a necessidades de cidadãos portadores de uma saúde mental que necessita de permanentes "retoques", afetos diferenciados e escuta ${ }^{3}$ sensivel.

Assim, essa tese tem por objetivo central compreender como o sujeito que vivencia a situação de sofrimento psíquico constrói suas experiências nas dimensões da cidade, partindo do interior de uma comunidade urbana, de onde são oriundos muitos "usuários" de serviços de saúde mental do municipio.

\footnotetext{
${ }^{2}$ Destaco alguns estudos desenvolvidos no Brasil que aprofundam a temática da enfermagem no campo da saúde mental: ROCHA, R. M. Enfermagem Psiquiátrica: que papel é este?; AGUIAR. M. G. G. A reinvenção do ser enfermeira no cotidiano da casa de saúde Anchieta e núcleos de atenção psicossocial; BARROS, S. O louco, a loucura e a alienação institucional: o ensino de enfermagem sob judice e KANTORSKI, L. P. O ensino de enfermagem psiquiátrica e saúde mental e a reforma psiquiátrica no Rio Grande do Sul.

${ }^{3}$ A escuta a que me refiro aqui é a escuta terapêutica feita pelos profissionais do campo da saúde. No entanto, também quero sinalizar que existem outras formas de "escuta" (por exemplo, as conversas informais, as diferentes formas de linguagens) que ocorrem nas interaçōes sociais dos sujeitos da pesquisa com as pessoas do local, e que, embora "não terapêticas" do ponto de vista do seu objetivo, são fundamentais em termos de autoafirmação, auto-estima e afeto.
} 
Essas reflexões me fazem defender a tese de que o modelo de atenção que predomina no campo da "saúde mental" em nosso municipio ainda é refratário às possibilidades de vida dessas pessoas, pois homogeneíza, padroniza e tolhe suas produções subjetivas, condicionando e determinando muitos de seus comportamentos dentro e fora das instituições, desconsiderando a autonomia e a liberdade como elementos necessários às expressividades do sofrimento e à centralidade dessas pessoas.

Neste trabalho, buscamos entender um pouco mais sobre o modo de vida dessas pessoas circulando em espaços abertos, mostrando que, se existe uma lógica típica dos serviços de saúde, também existe uma outra na prática cotidiana que traz uma produção singular, constituida de redes de sustentação, de referências construidas a partir de relações interpessoais pelos próprios sujeitos em sofrimento psíquico que possibilita apostar no investimento de outras propostas terapêuticas para além das que se limitam ao percurso da institucionalização.

O caminho escolhido nessa pesquisa foi, pois, o de trabalhar com espaços institucionais, gestalticamente ${ }^{4}$ falando, como figuras de fundo, trazendo para o contorno visual de destaque o próprio sujeito em sofrimento psiquico e seus familiares como protagonistas e participantes da construção metodológica da pesquisa. O exercício de "sair" das instituições não significa que estejamos negando a necessidade de serviços de saúde mental. $\mathrm{Na}$ verdade, o que pretendemos é refletir sobre a realidade concreta de Passo Fundo e descobrir outras possibilidades, questionando e propondo rupturas necessárias e, quem sabe, novos itinerários terapêuticos para as pessoas que adoecem mentalmente.

A fim de compreender o sofrimento psíquico da perspectiva de quem sente e sofre e de quem interage com o sofredor, além dos profissionais de saúde, fomos a campo em busca dos protagonistas que participariam desse estudo.

\footnotetext{
${ }^{4} \mathrm{Na}$ Gestalt o comportamento humano se expressa num contínuo no qual "necessidades" surgem como "figuras" a partir de um "fundo" que é a pessoa como um todo, com sua história e experiência, situado no seu espaço e tempo - no "seu mundo" (TELLEGEN, 1984).
} 


\section{Os primeiros enlaces entre pesquisados e pesquisador}

Considerando que todo o trabalho cientifico apóia-se nas construções do pesquisador, esse estudo tem seus alicerces na minha trajetória profissional no município de Passo Fundo iniciada na década de noventa, quando também me tornei uma moradora da cidade. $O$ ingresso na Universidade e na Secretaria Estadual de Saúde permitiu que eu desenvolvesse atividades de cunho acadêmico na disciplina de saúde mental do curso de enfermagem e de cunho administrativo no serviço público de saúde ${ }^{5}$.

Nesses espaços distintos conheci uma parcela da população que, recorrentemente, buscava alivio para o sofrimento psíquico o que me possibilitou conviver com situações existenciais concretas. Os contatos próximos e constantes foram trazendo elementos que compuseram um substrato de informações, conhecimentos, lembranças e inquietações em meu campo profissional e pessoal, permitindo a configuração de uma primeira cartografia desses "personagens-tipo"

O fato de estudar um tema a partir do meu universo de trabalho e de ter decidido desenvolver a pesquisa na minha própria cidade - que pelas suas caracteristicas permite conhecer pessoas, encontrá-las com freqüência, formar uma rede de relações bastante abrangente - foram elementos facilitadores no momento em que iniciei o percurso no bairro Vera Cruz, região delimitada como universo empírico, no sentido de que acabei me deparando com narrativas e moradores mais ou menos "conhecidos",

\footnotetext{
${ }^{5}$ Solicitei afastamento das duas instituições de trabalho durante a realização da pesquisa de campo, porque precisava de tempo para desenvolver o doutorado, mas também para garantir um distanciamento "mental" necessário à reflexão que o mergulho nas instituições, muitas vezes, nos impede de obter.

${ }^{6}$ Categoria escolhida por Scali Júnior (2002) para descrever um personagem em Retratos de subjetivação, que caracteriza a vida e o mundo subjetivo de pessoas que passam pelo processo de migração do campo-cidade pequena para uma metrópole. Através de alguns casos "tipo", o autor apresenta a possibilidade de analisar pessoas que vivenciam situações semelhantes ou equivalentes, ou seja: é um personagem que guarda em si caracteristicas comuns a vários outros personagens em um determinado contexto.
} 
incluindo os que me foram trazidos pela memória de outros moradores como os 'doentes mentais' do local. Foi assim que me aproximei de Bem-Te-Vi, João-de-Barro e Beija-Flor. Pomba-Rola e Sabiá7, outros "personagens-tipo", foram indicações decorrentes das minhas buscas pelo bairro.

Em conseqüência das relações profissionais envolvidas na pesquisa, faz-se necessário esclarecer alguns procedimentos metodológicos e algumas questões éticas.

No exercício das atividades acadêmicas, eu e meus alunos desenvolvemos atividades voltadas à escuta psíquica, como preparatórias da formação profissional. Isto nos coloca em contato com as histórias que os "usuários" nos contam e com os relatos confiados aos demais profissionais e registrados em prontuários individuais e especificos sobre os quais temos acesso irrestrito. Por isso, quando encontrei sujeitos já conhecidos em situação profissional, no tempo/espaço da pesquisa de campo, e porque optei por não privilegiar o institucional no estudo das relações cotidianas e seus significados, procurei cuidar para não trazer para o campo de pesquisa informações sigilosas e a mim confiadas no plano profissional, entendendo assim a necessária ética e distinção entre esses papéis. Na apresentação de cada um dos protagonistas trago dessas relações apenas informações relacionadas ao tempo cronológico e local em que nos conhecemos. As demais informações referem-se aos registros realizados em campo na fase de elaboração da pesquisa do doutorado.

Vale dizer que durante o desenvolvimento da pesquisa foram múltiplos os encontros dos protagonistas com esses espaços institucionais (serviços de saúde mental) e, portanto, repletos de significados, fazendo-os trazer freqüentemente, para a relação conosco, no processo da pesquisa, lembranças e sentimentos vividos nesses locais. Dessa maneira, o diálogo

${ }^{7}$ Os nomes foram substituidos por codinomes de pássaros regionais para manter o anonimato dos sujeitos. Tal escolha se deveu ao sentido metafórico da liberdade, inúmeras vezes citadas pelos sujeitos do estudo.

Os depoimentos colhidos durante o desenvolvimento da pesquisa serão destacados em itálico. 
sobre as instituições vem das experiências e interpretações dos próprios protagonistas e da minha capacidade de apreensão como pesquisadora.

Outro aspecto ético que vale a pena esclarecer é o da "permissão" para desenvolver uma pesquisa com um grupo que apresenta características emocionais tão peculiares - depressivas, eufóricas, paranóides, errantes ou, ainda, de isolamento social.

Algumas questões foram emergindo logo no inicio do trabalho. Como mergulhar num universo tão singular para compreender as relações cotidianas? Como ultrapassar barreiras criadas e papéis, por vezes hostis, construidos por algumas pessoas (os profissionais da saúde, por exemplo) que mantém uma "mediação" com a situação de saúde desses sujeitos? Em outras palavras, como desenvolver uma pesquisa que pretende trabalhar as relações interpessoais quando, na maioria das vezes, essas relações são marcadas mais pela violência do que pela argumentação, mais pelo silêncio do que pela comunicação, mais pela postura arredia do que pela possibilidade de exercer trocas?

Foi preciso, então, tomar algumas precauções para não invadir suas vidas, nem criar constrangimentos que pudessem piorar suas condições de saúde, já tão fragilizadas. Optei por um caminho que possibilitasse, inicialmente, construir o consentimento na relação, ao invés de utilizar mecanismos formais, pois entendia que o "aceito" formal do sujeito ou de seu responsável, não seria o passaporte para que um estudo dessa natureza pudesse se desenvolver. Neste caso, pensamos como Adorno e Castro (1994, p.183) que o mais importante é "o exercício de uma sensibilidade que tem como referência a experiência de mundos opostos $[\ldots]^{\prime \prime}$.

Assim trabalhei. Ao procurá-los, apresentava-me como pesquisadora, falando do meu interesse intelectual em conhecer suas vidas cotidianas, suas experiências, e os convidava a participar da pesquisa. Para construir esse tipo de relação precisei de investimento afetivo, tempo, dedicação, respeito e escuta. 
Foi desse modo que se deu a "entrada" de cada um na pesquisa e que "nasceu" um encontro entre pesquisados e pesquisadora, fundamental em estudos dessa natureza, envolvendo pessoas com características tão peculiares. Falo da relação de confiança estabelecida entre nós, sem a qual teria dificuldade em participar de seus circuitos pela cidade e de partilhar momentos extremamente significativos de suas vidas. Considero que essa tenha sido a condição essencial sem a qual a pesquisa não poderia ter se realizado.

Cada protagonista exigiu o estabelecimento de relações singulares e peculiares com a pesquisadora, inclusive para "dar um tempo" quando o momento vivido não estava "para conversa". De fato, era algo do campo do sensivel que me fazia voltar com freqüências diferentes em cada situação e também me desafiava a participar da produção do mundo de cada sujeito.

Foi assim que me aproximei de Pomba-Rola, João-de-Barro, BeijaFlor, Bem-Te-Vi, Sabiá e de seus familiares, tendo a grata surpresa de perceber o entusiasmo deles em minhas chegadas, as suas manifestações de alegria com os nossos 'encontros' que, quando demoravam a acontecer, eu era acionada através de uma rede de relações comuns que acabou se estabelecendo no local. Um dos protagonistas, inicialmente desconfiado quanto ao que eu faria com as conversas, passou a se manifestar de forma positiva, dizendo com orgulho: então a senhora quer saber sobre mim, não é pra me mandar pro hospital nem pro Caps?

Construir essa relação com os protagonistas fez-me perceber não apenas sua positividade no processo de pesquisa, mas a importância de interações propícias à escuta psicológica.

Cheguei até João-de-Barro através do auxilio de um mapeamento ${ }^{8}$, quando o localizei em sua casa e, coincidentemente nos

\footnotetext{
${ }^{8}$ Descrevo no capitulo metodológico como acessei esse documento que me possibilitou um mapeamento de "usuários" de serviços de saúde mental, moradores da região da Grande Vera Cruz.
} 
descobrimos conhecidos devido as suas primeiras internações psiquiátricas ocorridas dois anos antes. Tinha, naquela época, 32 anos de idade e trazia na lembrança as transformações ocorridas com a chegada das crises: a separação da mulher $e$, conseqüentemente, do filho que estava com dois anos, seu afastamento do trabalho de auxiliar de pedreiro, a perda de seus proventos e os episódios relacionados às convulsões e perda de controle de si.

Em seu relato, João-de-Barro fala da perda do controle como algo que vinha de dentro e que o fazia "explodir", tornando-se uma marca dos momentos mais graves da sua vida e, por vezes, uma barreira nas instituições que costumava freqüentar.

Registro no período inicial desse trabalho os sucessivos momentos em que João-de-Barro foi "dispensado" do Caps por apresentar comportamento "agressivo", indício de que se tratava de alguém cujo estereótipo deveria ser uma lente colocada diante do olhar dos profissionais e de todos os que dele se aproximavam. Barreira que marcou também as minhas primeiras aproximações com ele, pois ficava receosa ao encontrá-lo distante de sua familia ou de alguém que pudesse socorrer-me, caso necessitasse. Com o estreitamento das relações percebi que ele tinha um relativo controle de si e das suas diferentes situações de vida e que os episódios de "agressividade", além de ocorrerem em situações de maior fragilidade de sua saúde, não aconteciam em qualquer circunstância. Aconteciam muito mais, pela falta de um lugar de abertura para a subjetivação.

Beija-Flor, amante da rua, sabe bem o lugar aonde deve me receber, o que o faz convidar-me (quase) sempre empolgado: quando vai lá em casa?, ou, vai lá em casa hoje?. Também conhecido de longa data dos serviços de saúde e das suas 
andanças pelas ruas da cidade. Descobri nos primeiros meses da pesquisa que ele era um morador do bairro e referendado por seus habitantes como um típico caso para o meu estudo: aqui tem o Beija-Flor que não bate bem das idéias.

Quando identifiquei que ele era reconhecido pelos moradores como 'doente mental', estava internado. Tive várias conversas com sua mãe de quem ouvi um pouco de sua história. Disse-me que ele tem convulsões desde os seis meses de idade, e que sempre tomou muita medicação em decorrência da intensidade das convulsões, chegando a ficar muito mal aos nove anos. Eu sempre recorri à medicina, só à medicina, já faz 40 anos. Há quatorze anos internase com regularidade no hospital psiquiátrico da cidade, não sabendo precisar por quantas internações já passou (só no último ano foram três). Conta ainda que ele passa uns dias em casa e depois tem que internar de novo. Sabe como é o Beija-Flor: ele não é nada fácil, porque não é humilde. Ele arruma encrenca na rua, as pessoas ficam mexendo com ele, então se 'envareta' fácil. Ele não mexe com ninguém, mas se falarem qualquer coisa prá ele, ele já encrenca. Eu não sei porque as pessoas não são capazes de entender uma pessoa que é doente. Até as crianças mexem com ele.

Diz que o filho não consegue ficar muito tempo em casa, ele quer ir prá rua, vai por tudo, conhece todas as ruas e só anda a pé, não quer saber de ir de ônibus nem de carro. Ele gosta é de andar, mas só faz algum servicinho se pagarem, ai ele limpa um jardim, um terreno, mas afora isso, não. Quando o pai era vivo (morreu há dois anos) ele até ajudava um pouco a levantar o pai, pegar um sol, fazia companhia. Eu o conheci por essa época, lembro-me de que ele chegava no Caps dizendo que tinha que voltar logo para ajudar seu pai que sofria de uma doença degenerativa.

Passados alguns dias, voltei a casa e encontrei dona Maria (a mãe), fazendo faxina no porão - local onde Beija-Flor dorme: Tô limpando 
o quarto do Beija-Flor que tá numa sujeira! É aqui junto com a garagem e ele não é muito de limpar, o banheiro tá muito sujo. Embora não me desse muita atenção naquele momento, pareceume estar preparando o quarto para o retorno do filho que deveria receber alta em breve, dado o tempo que permanecia no hospital $e$ a informação de que estava melhor.

Ao saber do seu retorno fui procurá-lo, mas a mãe me disse: o Beija-Flor tá andando, graças a Deus tá bem, mas ele não pára, fica o dia inteiro à toa, por aí. No primeiro encontro sugerido pela mãe, Beija-Flor estava me esperando na rua em frente a sua casa e diz: a senhora veio me ver!

A partir dai nossos contatos aconteceram principalmente na rua, o que me fazia sentir como "malabarista", equilibrando o meu lugar, inclusive para não perder a confiança que, a todo o momento era colocada à prova com perguntas ou comentários, que ele fazia, as vezes irritado, sobre as minhas intenções para com ele, por exemplo, tentava descobrir se eu estava ali para interná-lo no hospital psiquiátrico. Andava muito rapidamente pelas ruas da cidade, como também eram muito rápidas as suas paradas. Seus contatos, suas histórias eram muito privativas, e, por vezes fantasiosas, o que exigia muito zelo nas nossas conversas e na observação para respeitar um "limite" que precisava ser captado em cada situação.

Demorei a entender, por exemplo, em que momentos eu poderia chegar em sua casa, pois, ao mesmo tempo que me cobrava: quando vai lá em casa?, também colocava condições: oh vá lá em casa num horário que eu esteja, ou, com a mãe e minhas irmãs em casa, não tem condições de conversa. Quando nos encontrávamos em sua casa na presença de seus familiares, ele sempre sinalizava que eu estava lá para conversar com ele, não tolerando que fizessem comentários a seu respeito, ou que interferissem em nossa 
conversa. Essa era uma situação muito valorizada por ele, pois afinal ali ele era o protagonista, sem a ingerência de um porta-voz como acontecia em quase todos os momentos de sua vida.

Pomba-Rola está em outra extremidade em relação à mobilização no espaço da cidade. Nunca consegui vê-la fora da área circunscrita do terreno onde mora com seus pais. Foram os vizinhos de Sabiá que me indicaram que no outro lado dos trilhos morava "alguém" que também poderia fazer parte de meu universo de pesquisa. $A$ partir dessas informações cheguei até sua casa, aonde, a partir de então, passamos a nos encontrar, juntamente com seus familiares.

Nascida no interior de um município vizinho mudou-se para essa casa com a família, ainda bebê. Estudou até concluir o segundo grau e, aos 18 anos, passou a trabalhar como operadora de caixa no maior supermercado do bairro, aí permanecendo até aos 22 anos, quando passou a apresentar problemas psíquicos. Atualmente, com 37 anos, sua conversa gira entre as lembranças do trabalho, do ex-namorado (o namoro acabou por ocasião da primeira crise), de não ter se casado, de ser ou não mulher (uma cartomante teria lhe dito, há mais de 10 anos, que o ex-namorado não era homem).

Em nosso primeiro encontro, o pai foi mediador da conversa. Espiando através da divisória entre a cozinha e a sala, como uma criança desconfiada, ela dizia que não tinha nada a falar comigo. Como o pai insistira, ela começou a responder perguntas que primeiro ele mesmo fazia: o nome completo, onde trabalhou, o nome do rapaz (ex-namorado de quem sempre fala), a idade. Fui, aos poucos, entrando na conversa e "quebrando o gelo" inicial.

Sua situação é de isolamento do convivio social mais amplo, circunscrevendo-se ao espaço da casa. As relações familiares fazem transparecer muito afeto, mas são marcadas por excessiva 
dependência. A familia queixa-se da dificuldade de tirá-la da cama e de convencê-la a desenvolver qualquer tipo de atividade, seja interna ou externa à casa, conforme explicita a mãe: de uns anos pra cá, começou a ficar em casa e agora não tem mais vontade de sair, não tem jeito, nem prá dar uma caminhadinha comigo.

Sabiá, um rapaz de semblante tranqüilo e pouca conversa é o mais novo dos protagonistas. Tem apenas 23 anos e, tal como ocorreu com Beija-Flor, demorei algum tempo para encontrá-lo, devido às internações sucessivas a partir do momento em que a "coisa ruim" começou a the "atentar", há três anos. Só no ano anterior à pesquisa foram três internações, totalizando cinco meses internado em hospitais psiquiátricos.

As primeiras informações sobre ele foram dadas pelos vizinhos que falavam de um rapaz, "na baixada", que estava "fora-de-si" e por isso fora internado. Por ocasião do seu retorno, voltei a sua residência e estabeleci o primeiro contato que o integrou a pesquisa.

Sabiá mora com um irmão, deficiente mental em decorrência de um acidente, a mãe e mais dois irmãos mais velhos, que moram no mesmo terreno em casas diferentes.

Bem-Te-Vi conheci há dez anos quando ingressei na universidade. $\mathrm{Na}$ ocasião ele já freqüentava o serviço ambulatorial de saúde mental (Grupo Nosso Espaço ${ }^{9}$ que posteriormente deu origem ao Caps), prática que exerce diariamente desde então. Nas primeiras caminhadas para reconhecimento do bairro passei a encontrá-lo com freqüência no percurso do ônibus que o conduzia ao centro da cidade, e o descobri também morador desse local. Observei que ele

${ }^{9}$ Grupo Nosso Espaço (GNE) foi o nome escolhido pelos "usuários" que freqüentavam e ajudaram a construir o serviço desenvolvido no Centro de Saúde de Passo Fundo, iniciado em 1990. 
era conhecido da maioria dos informantes que diziam que Bem-TeVi tinha uma "doença da cabeça" que requeria tratamento constante, mas, nas palavras de um morador, aparentava ser bem normal.

Meus encontros com ele foram mais restritos daqueles que estabeleci com os demais sujeitos, principalmente porque para encontrá-lo precisava recorrer normalmente ao Caps ou a pensão onde morava. Sua vida no Caps era marcada por rotinas que pouco se alteravam no dia-a-dia como: fazer as refeições, fumar, tomar chimarrão, participar de jogos e, eventualmente, de uma oficina de expressão, ou sair para a rua, entregando ou apanhando materiais solicitados pelo serviço. A minha chegada alterava a dinâmica, pois com o afastamento das atividades acadêmicas durante o período da pesquisa, eu me tornava uma visita, principalmente para o Bem-Te$\mathrm{Vi}$, mas também para os demais conhecidos do serviço, tendo de ouvir suas histórias e lamentações sobre as constantes mudanças de profissionais por que passava o serviço, com remanejamentos e novos quadros decorrentes de concurso público.

Ele é o único dos protagonistas que tem um outro suporte social em relação à moradia. Mora em uma "pensão", um quarto ao lado da casa da locatária, que também é a provedora de sua infra-estrutura, mediante o devido pagamento: alimentação, roupas de cama e banho e demais cuidados como, por exemplo, o cuidado da saúde. O espaço doméstico é disciplinado pela locatária e, respeitosamente, seguido por Bem-Te-Vi. Na metade do percurso da pesquisa ele mudou-se com essa "família" para outro bairro da cidade, dificultando assim a continuidade dos contatos no local de moradia.

Em sua história, fica distante o homem anterior ao adoecimento. Com 56 anos, viveu mais da metade de sua vida nessa situação, mas resgata nas minúcias do seu comportamento e das atividades 
que busca desenvolver, o encontro com a liberdade das remotas andanças com caminhões pela estrada a fora.

Foi do encontro especial com esses sujeitos que se dispuseram a compartilhar suas vidas, assim como, de tantos outros que fazem parte do campo de pesquisa, que resultou o presente trabalho. A construção do texto procura expressar o caminho seguido nesse processo.

No primeiro capítulo contextualizo brevemente a realidade da saúde mental do municipio de Passo Fundo, também constituída de espaços de convivência intensa dos nossos protagonistas. Para tanto, recorro aos informantes locais e aos documentos oficiais, no sentido de recuperar as circunstâncias que contribuíram para o desenvolvimento dos serviços e sua articulação com as políticas nacionais, sinalizando alguns aspectos de sua operacionalização.

No segundo capítulo apresento o caminho metodológico, enfocando a importância de buscarmos subsidios em outras áreas para a leitura das temáticas da saúde, como fizemos recorrendo à antropologia, especialmente para estudarmos as pessoas em sofrimento psiquico nas dimensões da cidade. Ao penetrar em terreno teórico-metodológico pouco conhecido, fui tateando e experimentando uma boa dose de ambigüidade, visto que buscava realizar uma autoria em meio a incertezas, indefinições e inseguranças. Todavia, quanto mais conseguia mergulhar nesse universo, mais me dava conta dos limites que se impõem, quando nos posicionamos tão longe e tão fora dessa realidade. Nesse capitulo, com a colaboração de diferentes moradores, apresento ainda o bairro Vera Cruz, local de moradia dos sujeitos do estudo.

No terceiro capitulo tentei estabelecer um diálogo com determinadas concepções teóricas sobre o processo saúde-doença mental, sobretudo a que predomina na atualidade. Também discuti a repercussão dessas teorias no cotidiano, entendendo que os conceitos se estabelecem através de diferentes processos de troca no contexto social e cultural. 
Apoiamo-nos, principalmente, no pensamento de Basaglia, percebendo a importância de sua teoria no questionamento e ruptura de um saber psiquiátrico que tolhe a liberdade e inibe a construção de identidades. Ao reconhecermos que essa é uma condição humana que envolve o sujeito em seus múltiplos aspectos, assumimos que estamos diante de um "problema complexo", que comporta principios de incompletude, incerteza e sensibilidade.

O quarto capitulo está centrado na cartografia cotidiana das pessoas que adoeceram mentalmente. Nesse momento da pesquisa foi possivel perceber que existiam, pelo menos, duas cartografias a respeito da temática. Uma, que chamei de oficial, com características institucionais bem delimitadas, e outra, a dos moradores do bairro que, mesmo reconhecendo a existência de pessoas com "problemas" (os "doentes mentais mesmo") restringia-se a um grupo específico, caracterizado por um conjunto de adjetivos sinalizadores de que a pessoa estava ou havia saído fora-de-si. Mesmo diante desse reconhecimento no cotidiano do bairro/cidade, esses cidadãos desfrutavam de relações bastante intensas com familiares, vizinhança, e com diferentes espaços construidos na busca da preservação de suas identidades, abaladas por todo processo que ocorre no adoecimento psiquico.

O quinto capitulo é uma reflexão sobre as diferentes trajetórias dos protagonistas no circuito de saúde. Discuto as relações e tensões que ocorrem "por dentro" do circuito, principalmente entre os sujeitos do estudo, seus familiares e profissionais de saúde. No sexto capítulo, destaco ainda outros espaços presentes nessas trajetórias e que expressam a busca de caminhos plurais percorridos pelos protagonistas, com a importante participação da promotoria e defensoria públicas da cidade nas estratégias de acesso à rede oficial de saúde e de ampliação dos direitos fundamentais.

Ao final, apresento algumas considerações sobre "as realidades" que pude captar, percorrendo com os sujeitos os espaços da cidade. De um lado, as relações com as instituições de saúde, lugares de intensas e 
contraditórias ações, que ainda deixam marcas profundas de privação de direitos fundamentais, além de um tradicional e restrito repertório terapêutico; de outro, as "invenções" singulares nos espaços da cidade, a trama das relações aí presentes, indicando a possibilidade e urgência de se pensar outros modos de compreender e de cuidar essas pessoas que mantém a esperança equilibrista de viver, de buscar escapes legítimos contra padrões estabelecidos a priori, de fazer valer seus desejos e construir novos processos de subjetivação. 


\section{CAPITULO I - ATENÇÃO A SAÚdE MENTAL EM PASSO FUNDO: historiando a organização dos serviços de saúde mental}

O primeiro movimento desse trabalho foi na direção de buscar documentos que facilitassem caracterizar a atenção à saúde mental em Passo Fundo ${ }^{10}$, pontuando, apenas, alguns momentos que marcaram os últimos anos e explicitando questões motivadoras deste estudo.

No município, a organização da atenção à saúde mental ocorreu de forma semelhante àquela das demais cidades brasileiras. A demanda por uma reorganização dos serviços de atenção à saúde da população de Passo Fundo surgiu com o crescimento da cidade, principalmente a partir da década de 1970, resultante de um intenso processo migratório rural (o município é considerado o maior da região norte do Estado do Rio Grande do Sul). Nesse período, Passo Fundo já dispunha de serviços hospitalares que serviam de referência para várias "especialidades", tanto no próprio município como na região como um todo.

No âmbito da saúde mental os serviços deixavam a desejar, restringindo-se a determinados e reduzidos procedimentos de assistência especializada, fato que levava as pessoas em sofrimento psíquico a ser encaminhadas para hospitais psiquiátricos em cidades distantes, como Porto Alegre e Pelotas.

Essas razões motivaram a comunidade espirita que, com a ajuda da sociedade local, viabilizou o projeto e a construção de um hospital psiquiátrico no municipio - o Hospital Espírita Bezerra de Menezes (HEBM) -, nos anos 1970 (18/06/1973 início da edificação, conforme Estatuto Social sob o registro de $n^{\circ} 588$ de 10/09/73 - HEBM, 1989).

Paralelamente a esse processo de construção do "Hospital Espírita", como ficou conhecido esse hospital, alguns profissionais também buscavam

\footnotetext{
${ }^{10}$ Cabe registrar a dificuldade de encontrar documentos que historiem a trajetória da saúde mental no município.
} 
desenvolver ações comunitárias de saúde mental na região. Foi então que, através do curso de psicologia da Universidade de Passo Fundo, constituiuse o Centro Comunitário de Saúde Mental, propondo a integração do ensino, serviços e pesquisa. De acordo com Carmen Oliveira (1983), uma das professoras que idealizou a proposta:

O centro comunitário de saúde mental tem na sua história a preocupação do profissional de saúde mental na sua relação com a vida do homem do campo e da cidade de Passo Fundo. Desde sua implantação em 1974, o CCSM vem se preocupando com algumas situações de vida do municipio: com o doente mental pobre (duplamente marginalizado pela loucura e pela pobreza, desassistido, condenado ao "pastilhismo" ${ }^{11}$, filas de espera, hospitalização), com o migrante rural (expulso de sua terra, exposto a fatores patógenos, tais como o subemprego e perda de seus referenciais), com a periferia urbana (condenada à baixa qualidade de vida, opressão e exploração).

Partindo do reconhecimento de que o trabalho assistencial e curativo desenvolvido até então não conduziu à alteração do quadro de oferta de serviços à demanda cada vez mais crescente e, considerando também a certeza de que a morbidade mental e a melhoria do nivel de saúde da população dependeria, fundamentalmente, da melhoria das condições de vida, em outubro de 1981 o CC parte de uma redefinição do seu trabalho.

A proposta de um atendimento comunitário e preventivo não surgiu apenas de uma crítica ao sistema tradicional (ineficaz, cronificador e elitista) de atendimento do doente mental, ou com base no modelo de seus homônimos americanos (extensão de cobertura, simplificação e descentralização de atendimento). Entende-se que estas duas formas de prestação de serviços contém, em sua essência, uma mesma proposta de adaptação do indivíduo e de regulação da vida social.

O Centro Comunitário se apresenta, como intenção e práxis, negando o papel que o sistema de saúde tem atribuído ao profissional de saúde mental. Nosso compromisso vai em oposição a esse papel adaptativo-repressivo, utilizado para a manutenção de uma sociedade doente e injusta. Buscamos uma psicologia comunitária, descolonizada, interessada na problemática de nossa cidade, região e país; uma psicologia comunitária interessada não apenas na degradação mental das pessoas, mas em todas as formas de degradação a que estão submetidos os marginalizados, os despossuidos e explorados da nossa terra; uma psicologia comunitária que situe as personalidades alienadas como produto de um sistema econômico predatório de nossa saúde e de nossa cultura; uma psicologia comunitária que questione nossa formação acadêmica e ofereça possibilidades de recriar posturas e conhecimentos.

\footnotetext{
${ }^{11}$ Termo regional usado para caracterizar o percurso vivido por determinados grupos sociais em analogia ao processo utilizado na produção de pastilhas, quando um material pulverulento (pó), toma o formato (de pastilha - peça para revestimento de parede) por compressão.
} 
Pelo relato da professora é possivel perceber a sua preocupação com o delicado momento vivido pela população, decorrente das constantes mudanças sociais e econômicas por que passava o município, e da correlação dessas com os processos de agravamento do psiquismo. Além disso, a assistência às pessoas que necessitavam dos serviços de saúde, ao invés de aliviá-los, agravava ainda mais as suas já tão fragilizadas situações de vida, uma vez que o eixo central dessa assistência pautava-se no isolamento e na adaptação social dos sujeitos, carecendo de um modelo preventivo e de um novo espaço social para a sua ação.

Assim, Oliveira, ao mesmo tempo em que sinaliza para a necessidade de um serviço preventivo e comunitário no município tece uma crítica ao que ocorria no modelo preventivista da época adotado pela política de Kennedy nos Estados Unidos da América, e que se tornaria referência para os demais países: "extensão de cobertura, simplificação e descentralização de atendimento". Essa política desencadeou-se na década de 1960, quando os EUA encontravam-se em meio a graves problemas, como a guerra do Vietnã, o aumento do uso de drogas entre os jovens, o aparecimento de gangues, o crescimento progressivo dos distúrbios mentais, enfim, conforme Amarante (1995, p.38), "uma série de indícios de profundas conturbações no nivel da adaptação da sociedade e da cultura, da política e da economia", ressaltando-se os gastos e prejuízos econômicos com a assistência psiquiátrica. Em vista disso, estabeleceu-se uma nova política pública psiquiátrica norte-americana, a Psiquiatria Preventiva ${ }^{12}$, que representava a demarcação de um novo território para a psiquiatria, já que a terapêutica das doenças mentais deveria dar lugar a um novo objeto: a saúde mental.

\footnotetext{
${ }^{12}$ Gerald Caplan (1980) é o principal difusor da Psiquiatria Preventiva ou Comunitária da época através da obra: Princípios da psiquiatria preventiva. O projeto preventivo em termos teóricos, entre outros, incorpora da saúde pública o conceito da história natural das doenças de Leavell e Clark, que discrimina três tempos na formação e desenvolvimento da enfermidade, até a sua resolução, e estabelece três formas distintas de intervenção, de acordo com o momento de sua constituição: prevenção primária, secundária e terciária. Acrescido a esse conceito traz da psicologia a noção de "crises vitais" (evolutivas e acidentais) sendo essas, um grande indicador do desequilibrio ou de sua possibilidade (BIRMAN e COSTA, 1994).
} 
A prevenção primária era a maior novidade desse projeto e, onde os esforços técnicos e financeiros deveriam se concentrar. No entanto, Birman e Costa (1994, p.56), ao avaliarem suas bases teóricas e práticas, fazem um paralelo entre a reforma asilar e essa nova proposta. Na primeira, a promoção da saúde mental era constituída pela busca de uma adaptação aos ideais estabelecidos para os grupos do hospital; no novo contexto, buscou-se ativamente promover a adaptação aos ideais dos grupos instituidos no espaço social, já que a desadaptação passou a ser signo de doença ou de sua possibilidade, sendo registrada no mundo patológico. Com isso, em nome da psiquiatria preventiva, não apenas mantém-se o sistema cronificador das pessoas que vivem o adoecimento mental, como se amplia - quadro, com "novos psiquiatrizados", desviantes, não adaptados às respostas esperadas socialmente, aumentando-se a população de dependente dos serviços psiquiátricos.

No final da década de setenta e início dos anos oitenta, sob forte influência da psiquiatria preventiva, aconteciam outras experiências de serviços "extra-hospitalares" no Estado do Rio Grande do Sul, ligadas principalmente, às universidades e ao próprio Hospital Psiquiátrico Estadual $^{13}$. As péssimas condições e superlotação desse último foram os principais motivos que levaram o Estado a propor metas de desospitalização, setorização do atendimento, interiorização de recursos, prevenção em saúde mental e o aproveitamento de recursos locais e não especializados (médicos clínicos gerais e auxiliares de saúde nas Unidades Sanitárias ou Centros de Saúde) para desenvolver ações de saúde mental nos municipios (RIO GRANDE DO SUL, 1981) ${ }^{14}$.

Algumas cidades maiores, sedes das regiões sanitárias do Estado, como Passo Fundo, também passaram a contar com profissionais de saúde

\footnotetext{
${ }^{13}$ Hospital Psiquiátrico São Pedro, o primeiro a ser construído no Estado do RS, em Porto Alegre, no ano de 1884. Mantém-se, até hoje, com uma população de internos divididos em dois grandes módulos assistenciais: o módulo de residentes (serviço de crônicos) e o módulo de agudos (serviço de internação de pacientes agudos: curta estadia).

${ }^{14}$ Manual de Treinamento em cuidados primários de Saúde Mental da Secretaria de Saúde e Meio Ambiente do Rio Grande do Sul, 1981.
} 
mental (psiquiatra e psicólogo) ${ }^{15}$ que se constituiam em ponto de referência para os demais municípios da região, como também passaram a receber pacientes egressos de hospitais psiquiátricos e tratá-los em ambulatórios. Esse periodo foi marcado especialmente pelo grande número de internos do hospital São Pedro que foram levados de volta aos seus locais de origem.

Percebe-se que existiam pelo menos duas grandes linhas de pensamento sobre a organização do "modelo de atenção", correndo paralelas no Estado e municipio. De um lado, a que propunha a manutenção do tratamento psiquiátrico em grandes hospitais destinados a esse fim e, de outro, a proposta de abertura de serviços comunitários próximos ao local de moradia dos possiveis "usuários".

Ao final da década de oitenta e início dos anos noventa do século passado, o modelo de atenção vigente foi intensamente questionado ${ }^{16}$, tanto no município, quanto no Estado e Federação. Apesar das modificações propostas nos anos anteriores que resultou na abertura de novos serviços ambulatoriais, na diminuição do número de moradores na instituição psiquiátrica e na diminuição da permanência dos internados, a qualidade da assistência à saúde mental continuou se agravando. Se, por um lado, a população do hospital São Pedro foi reduzida, diminuindo assim a superpopulação e os custos do hospital, por outro, não ocorreu o devido suporte às famílias $e$ às comunidades que acabaram reproduzindo a

\footnotetext{
${ }^{15}$ Informação obtida junto ao psicólogo Hélio Possamai, funcionário da Secretaria de Saúde e Meio Ambiente/RS, atuando na região de Passo Fundo no periodo referido.

${ }^{16} \mathrm{Em}$ 1987, como desdobramento da $8^{\mathrm{a}}$ Conferência Nacional da Saúde, aconteceu a primeira Conferência Nacional de Saúde Mental. Ai, foram apontadas diretrizes gerais para a descentralização, a gestão única em cada esfera de governo, o controle social, a integralidade e o conceito de saúde enquanto direito à cidadania.
}

Em 1988, a Constituição Brasileira aprova o SUS - Sistema Único de Saúde.

Ao final dos anos 1980 e inicio de 1990, muitos profissionais integrantes do governo estadual, também sintonizados no movimento nacional de transformação no campo da saúde mental, e apoiados na proposta nomeada de pensamento estratégico de Mário Testa desafiaram-se a produzir algo novo, investindo fundamentalmente no campo da capacitação de pessoas. Esse investimento resultou na implantação de serviços de saúde mental em vários municípios do Estado. Passo Fundo foi sede de um dos cursos de aperfeiçoamento em saúde mental, momento marcado por embates na cidade pelo fato de alunos e professores tornarem público que o hospital psiquiátrico não deveria ser aberto. 
cronificação e exclusão dos doentes nas próprias casas ou em instituições locais, com o conseqüente agravamento de seus problemas.

As reflexões e diretrizes presentes no conjunto das Conferências e documentos produzidos por trabalhadores, "usuários", familiares e tantos outros integrantes da sociedade civil que propunham abandonar a centralidade do hospital psiquiátrico rumo a um trabalho prioritariamente "extra-hospitalar" de base comunitária, enfocando a cidadania como questão central, também repercutiram no cenário local, apesar da morosidade de sua incorporação enquanto política pública.

Estabeleceu-se assim uma discussão entre diferentes grupos na busca de outras estratégias. Enquanto membros das coordenações estadual e regional da saúde mental negociavam a não abertura do hospital psiquiátrico e apresentavam estratégias para a situação "de pessoas em crise aguda", outros setores da comunidade (instituições hospitalares, religiosas, profissionais da saúde, universidade, políticos locais e outros setores do executivo estadual) buscavam sua implantação definitiva. Durante, aproximadamente, dois anos antes da abertura do "Hospital Espírita" chegou a funcionar uma unidade psiquiátrica com quarenta leitos no hospital municipal (Hospital Beneficente Dr.César Santos) ${ }^{17}$.

Nesse mesmo periodo, maio de 1989, acontecia a experiência de Santos, em São Paulo, quando a gestão municipal de saúde, após receber inúmeras denúncias de maus-tratos e mortes violentas, propôs a intervenção no hospital psiquiátrico local - Casa de Saúde Anchieta -, iniciando um processo de profundas transformações do sistema psiquiátrico (que culminou no fechamento do hospital) e na re-orientação da política de saúde mental da cidade. Tal fato, ocorrido imediatamente após a aprovação do Sistema Único de Saúde pela Constituição Brasileira, tornou-se um marco na história nacional, pois provocou uma ruptura com o modelo manicomial e preventivista vigente, criando condições para a implantação de serviços de

\footnotetext{
${ }^{17}$ Informações obtidas junto ao Coordenador da política regional de saúde mental da época, o psicólogo Hélio Possamai (1987-1990).
} 
saúde mental, especialmente os Núcleos de Atenção Psicossocial (NAPS), de caráter completamente substitutivo ao manicômio, de base territorial, abrindo ainda um debate público sobre a segregação e a exclusão social (CAMPOS e HENRIQUE, 1996).

Mesmo diante desse cenário, em março de 1990, quase vinte anos depois do início das obras, a Secretaria do Estado do Rio Grande do Sul autoriza a abertura do Hospital Espírita Bezerra de Menezes de Passo Fundo ${ }^{18}$ que estava pronto para receber "pacientes em crise aguda", sendo o único do gênero em toda a região. Permanece em funcionamento até hoje, mantendo caracteristicas físicas e estruturais tradicionais, e semelhantes às demais instituições psiquiátricas. Localizado em uma região periférica, na extremidade de um bairro e ao lado dos trilhos ferroviários, o que expressa o caráter simbólico da necessidade do isolamento social a que são submetidos os seus habitantes.

Naquele momento, a proposta original do Centro Comunitário de Saúde Mental já estava enfraquecida, perdendo sua força inicial de um serviço que alavancasse as mudanças no modelo de atenção à saúde mental na cidade. Ainda no ano de 1990 e, como desdobramento desses acontecimentos tanto no plano local, como estadual e nacional, constituiu-se um novo serviço ambulatorial, no Centro de Saúde (Estado) para pessoas com transtornos psiquicos graves que se propunha a criar um espaço de cuidado, aberto e comunitário, sendo o projeto-embrião do atual Centro de Atenção Psicossocial ${ }^{19}$ do município.

\footnotetext{
18 Já em 1989 a Sociedade Espírita Bezerra de Menezes realizou convênio com o Hospital da Cidade de Passo Fundo $(\mathrm{HC})$ para viabilizar o funcionamento do referido hospital. Em 24/03/1990 iniciou suas atividades (Ata de inauguração $n^{\circ} 10$ de 24/03/1990). Desde os primeiros anos apresentou dificuldades financeiras para atender suas necessidades, pois não conseguia credenciamento oficial do Estado. O convênio com o Hospital da Cidade foi sendo renovado, ampliando também as suas responsabilidades, até que em 1993 o Hospital Espírita foi definitivamente incorporado ao Hospital da Cidade de Passo Fundo, passando a se chamar: Hospital Psiquiátrico Bezerra de Menezes. A partir de então, foi credenciado no Sistema Único de Saúde. (Ata de $n^{\circ} 13$ de 10/12/1993, Ata de $n^{\circ} 122$ de 20/12/1999 e Ata de $n^{\circ} 14$ de 30/12/1993).

${ }^{19}$ Centros de Atenção Psicossocial - Modalidade de serviço instituida e regulamentada pelas portarias 189 de 19 de novembro de 1991 e 224 de 29 de janeiro de 1992. Os Caps foram atualizados pela portaria n. ${ }^{\circ} 336 \mathrm{em} 19$ de fevereiro de 2002. Por esse documento, os
} 
As manifestações de um movimento social que desejava colocar em pauta um projeto de reforma psiquiátrica no Estado repercutiram também no âmbito jurídico-político quando a Assembléia Legislativa do Rio Grande do Sul aprovou em 1992 a Lei da reforma psiquiátrica, primeira do país, determinando a substituição progressiva dos leitos nos hospitais psiquiátricos por uma rede de atenção integral em saúde mental junto ao Sistema Único de Saúde. A mesma lei estipula regras de proteção aos que padecem de sofrimento psíquico. Nesse aspecto, a lei determina que pessoas com transtomos em saúde mental não sofram limitações em suas condições de cidadãos e sujeitos de direitos, livres de internações de qualquer natureza ou outras formas de privação da liberdade (RIO GRANDE DO SUL, 1992) ${ }^{20}$.

A reforma psiquiátrica explicita um "processo social complexo" que necessita interferir nos saberes e práticas, estabelecendo novas relações e experiências de vida, não podendo ser entendida ou simplificada como reorganização dos serviços. Amarante (2003) busca uma nova conceituação de Reforma psiquiátrica que nos parece bastante consistente para a compreensão desse processo, pois envolve, simultaneamente, diferentes dimensões inter-relacionadas. Uma primeira dimensão é a teórico-conceitual "que tem como maior mérito a proposição de opor-se à naturalização/objetualização da noção de doença. Esta deixa de ser um objeto naturalizado, reduzido a uma alteração biológica ou de outra ordem

serviços deverão estar capacitados para realizar, prioritariamente, o atendimento de pacientes com transtornos mentais severos e persistentes em sua área territorial, em regime de tratamento intensivo, semi-intensivo e não-intensivo, conforme classificação: I, II, III, i (infância) II e ad (álcool e drogas) II, tendo especificação em termos de abrangência populacional, turnos de funcionamento e equipe. Cabe salientar que é essa a única modalidade específica da saúde mental não hospitalar com financiamento do Ministério da Saúde até o momento.

${ }^{20}$ No final do mesmo ano, e com a mobilização de milhares de pessoas, entre eles, os "usuários" dos serviços de saúde mental realizou-se em Brasilia a II Conferência Nacional de Saúde Mental que reafirmou como marcos conceituais a atenção integral e a cidadania. A atenção integral indica a necessidade de uma rede de dispositivos sanitários e socioculturais que partam de uma visão integrada das várias dimensões da vida do sujeito, em diferentes e múltiplos âmbitos de intervenção. A cidadania "é uma construção histórica resultante das problematizações concretas que cada sociedade produz" devendo estar vinculada a um conjunto de esforços coletivos, de modo que cada pessoa possa, cada vez mais, influir nas questões que the digam respeito (CONFERENCIA NACIONAL DE SAÚDE MENTAL, II, 1992). 
simples, para tornar-se um processo saúde/enfermidade [...] uma experiência nas vidas de sujeitos distintos" (53). Para estabelecer uma relação técnico-instituição-sujeito são necessárias inovações no âmbito técnico-assistencial, a segunda dimensão elencada pelo autor que implica na construção de um novo modelo de atenção à saúde, ou seja, de um amplo repertório de recursos/serviços articulados, diversificados, porosos, democráticos, responsáveis, com base territorial e, com ofertas, que ajudem as pessoas a conquistarem, gradativamente, novos patamares de existência subjetiva, de autonomia. Soma-se a essas, a dimensão juridico-politica que se refere à rediscussão e redefinição das "relações sociais e civis em termos de cidadania, de direitos humanos e sociais" (53), dado ao conjunto de noções que ainda se relacionam com essa condição de vida, entre eles, a periculosidade, a incapacidade e a irresponsabilidade civil. Por fim, a dimensão sociocultural, que expressa a necessidade de transformação do lugar social da loucura.

Rebatendo as criticas que alguns autores têm apresentado em relação a uma suposta "carência clínica" nas experiências da reforma psiquiátrica, justificadas na tese de que essa última privilegia a relação e/ou as transformações sociais e políticas em detrimento da clínica, Amarante (2003) argumenta que é na e pela articulação dessas várias dimensões que se torna possível uma nova relação com a loucura e que essa, necessariamente, precisa subsídios de diferentes campos do conhecimento. Em outras palavras, entendo que é necessário tomar a trajetória desse sujeito como guia de percurso, ajudando-o a construir respostas e sentidos, inclusive para recompor sua história, muitas vezes "deformada" pela relação com a "doença".

Nesses anos de exercício da profissão, acompanhando a atenção à saúde mental no município, posso afirmar que a reforma psiquiátrica na concepção acima exposta é algo distante da realidade de Passo Fundo. Mesmo com o surgimento de iniciativas ambulatoriais, como o Centro Comunitário e o serviço ambulatorial do Centro de Saúde (posteriormente Caps), o hospital psiquiátrico é o serviço de saúde de maior referência para 
tratamento de pessoas com problemas psíquicos da cidade e região norte do Estado. Ao longo desse percurso, as mudanças da política institucional, do governo estadual e municipal e da própria universidade, acabaram por provocar nos anos que se sucederam uma retração nos investimentos, resultando no afastamento de profissionais ligados aos serviços ambulatoriais e na fragilização de um projeto institucional capaz de romper com o tradicional circuito psiquiátrico.

Com pouco mais de uma década, algumas características do funcionamento do hospital possibilitam perceber semelhanças com as tradicionais instituições psiquiátricas como, por exemplo, o isolamento, o caráter impessoal e disciplinador do seu atendimento. Há uma dinâmica na estrutura da instituição que privilegia uma única oferta terapêtica ${ }^{21}$, medicando todos os internados, na maioria das vezes, com altas doses de psicofármacos, delineando um "retrato" típico dessa lógica institucional: pessoas sedadas, dormindo durante longas horas do dia ou, com fala e marcha arrastadas, pelos corredores em busca dos profissionais, querendo falar-lhes, pedindo alta, pedindo visitas e notícias da familia, cigarros e roupas, ou, queixando-se de outros internos.

Antes de esclarecer em que circunstâncias é possível justificar uma internação psiquiátrica, vale lembrar que a legislação que propõe mudanças na atenção é recente no Brasil, e que não se modifica um modo de pensar e nem um comportamento na mesma velocidade que se aprovam leis, portarias ou decretos. Ainda que a mudança na legislação no campo da saúde mental tenha ocorrido em conseqüência de um "movimento social" que clama por ações e serviços mais dignos e qualificados para o cuidado dos sujeitos que vivem a experiência do sofrimento psíquico, observa-se que a formação e capacitação dos profissionais de saúde mantêm-se pouco sintonizada com as necessidades que favorecem o desenvolvimento e as potencialidades desse ser humano.

21 Outras "modalidades de atenção" desenvolvidas: atividades em grupos terapêuticos, oficinas terapêuticas e atendimentos individuais. Além disso, há permissão para visitas durante duas horas diárias e acesso ao pátio interno, "salvo em casos de limitações combinados pela equipe" (HC-HEBM, 2003). 
Segundo a portaria que regulamenta o controle das internações psiquiátricas (BRASIL, 2002), essa "somente deverá ocorrer após todas as tentativas de utilização das demais possibilidades terapêuticas, e esgotados todos os recursos extra-hospitalares disponíveis na rede assistencial, com o menor tempo possivel". Nessas condições, tal procedimento tem como meta a oferta temporária de um ambiente protegido, tecnicamente instrumentalizado, que forneça suporte à situação de crise entendida como um

[...] momento de ruptura, de descontinuidade tanto para o sujeito como para o meio social, os quais demandam cuidados intensivos e situações emergenciais. Intervenções essas, que visam reconstruir a história da crise, como também, pontuar situações do cotidiano que possibilitem, ao sujeito, tomar posse dos acontecimentos de sua vida como algo próprio (ZAGO et al., 2001, p.83).

Embora o projeto terapêutico do hospital preconize uma internação "dentro de um período curto, visando a reabilitação psicossocial" (HC-HPBM, 2003), pude perceber durante o periodo em que desenvolvi a pesquisa, que as experiências dos "usuários" acompanhados nesse espaço institucional não refletem a proposta oficial do serviço ou, a preconizada para serviços da mesma natureza. Casos como o de Beija-Flor esclarecem a questão.

Ele passa grande parte de sua vida nessa instituição. Em nove meses, registrei uma permanência de quatro meses e meio de internação. Ao encerrar um período legalmente permitido para a permanência hospitalar, ele recebia alta e voltava para casa. Passado o tempo de "carência" do plano de saúde, podia retornar para nova internação. Em outros casos, constatei que os internos permaneciam até três meses no hospital, ininterruptamente. Ao analisar as informações no Sistema de Internação Hospitalar do Sistema Único de Saúde (SIH-SUS), pude observar que uma nova internação podia ocorrer poucos dias depois do hospital ter gerado um documento de alta hospitalar.

Os mecanismos e encaminhamentos legais, a exemplo do sistema de regulação das internações, "sofrem" alterações que parecem expressar 
diferentes conflitos (de idéias, de interesses, econômicos, afetivos, sociais, etc.) com as situações vívidas pelos envolvidos no processo de internação psiquiátrica, apontando a complexidade dessa tomada de decisão.

Essa complexidade tem reflexos imediatos sobre o sujeito, como por exemplo, o seu consentimento para admissão no hospital. O projeto terapêutico prevê que "sempre que é possivel o usuário é informado sobre sua internação com o objetivo de assegurar (ao mesmo) o direito de manifestar vontade, formar opinião e compreender a natureza de sua decisão", podendo a internação ser voluntária ou involuntária. A involuntária, somente "a fim de evitar dano imediato ou eminente ao usuário ou a terceiros" (HC-HPBM, 2003). Ao contrário disso, há, regularmente, uma falta absoluta de negociação e consentimento da pessoa a ser internada em relação a esse procedimento que se apresenta a ela, via de regra, como obrigatoriedade de engajar-se em um tratamento. Este tipo de orientação está presente tanto nos depoimentos dos "usuários" como nas observações que realizei na condição de pesquisadora. É, por exemplo, o que afirma um familiar: disse que ia levá-lo pra consulta, mas já era pra internar. Ele ficou bem brabo, disse que enganam ele pra deixar naquela prisão, mas fazer o que, né? Ou, o que aparece no relato de Sabiá:

Se eu soubesse que não era só pra fazer uns exames como me
disseram, eu não tinha ido lá nem amarrado, porque quem não é
louco lá se torna [...] sei que quando me dei conta que estava
trancado e disseram que só saía depois de um, dois, três meses
$[\ldots .$.$] , eu comecei a ficar nervoso e me agitar [...] depois os$
companheiros me ensinaram que esse tipo de comportamento só
denunciava contra mim.

Concordo com Lobosque (2001) que, mesmo em crise aguda e franca, há sempre um ângulo, uma ponta, um fio, onde podemos fazer o portador de sofrimento psiquico ouvir. Mas a questão que parece central é a da violação de direitos fundamentais de um cidadão que, fragilizado por uma situação de vida, é excluído da discussão de seu próprio projeto terapêutico, passando ao dominio da instituição. Nesse domínio o sujeito é despojado do seu eu, de todo o signo de sua identidade. Estabelece-se, nessas circunstâncias, uma dinâmica perversa, ou seja, para não ficar mais tempo 
internado e não se rebelar (o que comprovaria seu estereótipo de louco, violento, perigoso), o sujeito é forçado a negar sua individualidade, sua necessidade de sociabilidade, tendo de interiorizar o comportamento aceito na instituição, o único que the possibilita um trânsito institucional mais rápido, porque responde adequadamente às suas normas.

As relações estabelecidas entre as pessoas que fizeram parte desse estudo e algumas das instituições de saúde, nos remetem a Erving Goffman (2001), pois contemplam, em grande medida, caracteristicas muito semelhantes às "instituições totais" estudadas por ele na década de sessenta do século passado. Tais instituições criadas para cuidar, dentre outros, de pessoas incapazes de cuidar de si mesmas e que representam "riscos" não intencionais para a sociedade (como por exemplo, pessoas com doenças infecto-contagiosas e mentais,...) apresentam um caráter envolvente e totalizante caracterizadas por barreiras (concretas ou simbólicas) ao intercâmbio social com o mundo exterior.

O seu público passa por um "desculturamento" por meio de uma carreira moral que se inicia antes de mais nada pelo rebaixamento pessoal, pelo sofrimento de humilhações e pelas mais diversas maneiras de profanação do eu. Mesmo diante das rígidas regras institucionais das "instituições totais", os internos procuram enfrentar, ou melhor, adaptar-se a degradante situação de vida a que são continuamente submetidos. Dentre as maneiras descritas por Goffman (2001) para enfrentar a tensão entre o seu mundo e o mundo institucional, destacaremos duas pela semelhança com o que relataram nossos protagonistas. A primeira refere-se à tática da intransigência, quando o interno desafia a instituição, negando-se a cooperar com as atividades ou terapêuticas direcionadas a ele. Nesses casos, se a instituição entende que o internado deve ser vencido, mostra-lhe "uma devoção tão especial quanto ao que o rebelde manifestou em relação a ela" (GOFFMAN, 2001, p.60), fato que pôde ser observado por um de nossos depoentes ao chegar no hospital psiquiátrico. Avisado e dando-se conta de que essa reação não possibilitaria a ele imprimir algo seu nessa interação, uma segunda maneira de reagir aparece: a conversão. Nessa última, o 
internado parece aceitar as regras da instituição e procura representar o papel do "internado perfeito", inclusive ajudando a controlar outros pacientes, impondo-lhes também as regras institucionais, podendo assim interromper, em parte, um tipo de comportamento.

As atividades cotidianas do hospital são também lembradas por Beija-Flor, permitindo que visualizemos sua rotina de interno: levantar, tomar o remédio, tomar café, ir para o pátio - se não tiver chovendo -, tomar remédio, ir para o pátio, jantar, tomar remédio, ver televisão e dormir. Novamente, a semelhança com os aspectos comuns das "instituições totais" descritos por Goffman (2001): todas as esferas de vida (trabalho, lazer, repouso,...) acontecem em um mesmo local e sob uma única autoridade, sendo as atividades diárias executadas dentro de linhas estreitas, numa rotina imposta verticalmente, através de regras formais explícitas, sob o controle de funcionários da organização. $O$ internado é obrigado a pedir permissão para executar determinadas ações que antes eram triviais em suas vidas.

A submissão a métodos coercitivos, as relações de poder entre equipe dirigente e internados, a exemplo do que acima referimos, dentre tantas outras características, faz com que a pessoa internada seja despojada de sua identidade pessoal, levando a uma desfiguração padronizada e ao progressivo abandono do eu. Nos termos do autor, provocando a sua "mortificação".

Para um andante, amante da rua como Beija-Flor a reclusão no espaço fechado e a impossibilidade de exercer a sua singularidade são seus maiores castigos, fazendo com que a expressão: não me fale de hospital seja uma marca constante nos nossos encontros. Trava-se nele uma luta contra a "mortificação do eu". É um retrato que traz à tona uma reflexão sobre as "terapêuticas" predominantes - o princípio pineliano do isolamento terapêutico, através da instituição psiquiátrica e do tratamento moral, por vezes bastante sutil e consentido, através das atitudes impositivas, dos excessos medicamentosos, do trabalho "terapêutico", entre tantos outros 
empregados na história da psiquiatria - e as contradições delas decorrentes. Contradições essas que podem ser evidenciadas ao retomarmos a idéia de Zago et al. (2001) sobre a importância de um espaço no qual o sujeito possa restabelecer a sua história conectada a uma trajetória cotidiana que lhe possibilite ser sujeito nesse processo. Que tipo de representação sobre o hospital Beija-Flor construiu que o faz ter horror a essa instituição, a tal ponto de pedir de forma reiterada para que não mais nos refiramos a ela? Como é possivel a reconstituição da sua história, estando ele recluso no hospital, numa rotina/disciplina rigida que não dá vazão a sua produção subjetiva, aos seus desejos e singularidade. Ele não participa do seu projeto terapêutico, não é ouvido; ao contrário, sua fala é, com freqüência desqualificada, desacreditada, não existindo (ou se existe é insuficientemente incorporada como parte do projeto terapêutico) conexão com a sua história fora do hospital - na família, na rua. Enfim, não há um projeto que crie expectativa de trabalhar sua estrutura psiquica, esfacelada diante desse processo de sofrimento, nem de melhorar suas redes após a alta hospitalar de tal modo a fortalecer seus vínculos e continuar buscando espaços que ajudem na reorganização e ressignificação de sua vida. Resta perguntar, pois, de que reabilitação ou atenção psicossocial estamos falando?

A reabilitação psicossocial ${ }^{22}$, mencionada no plano terapêutico do hospital, merece uma breve reflexão, apesar desse documento apresentar limitações para análise por não explicitar melhor a compreensão de tal conceito. Tomemos então um dos autores que tem discutido e publicado sobre essa temática no Brasil, o italiano Benedetto Saraceno (1999). Ele reafirma a esquematização da Organização Mundial da Saúde (OMS) da

\footnotetext{
${ }^{22}$ Alguns autores que refletem sobre o tema que tomou uma maior dimensão a partir da World Association for Psychosocial Rehabilitation (WAPR) criada em 1986 na França e apoiada pela Organização Mundial da Saúde: PITTA, A.M.F. (org.) Reabilitação Psicossocial no Brasil. São Paulo: Hucitec, 1996; SARACENO, B. Libertando Identidades: da reabilitação psicossocial à cidadania possível. Rio de Janeiro: Instituto Franco Basaglia/ Te corá, 1999; HIRDES, A. Reabilitação Psicossocial: dimensões teórico-práticas do processo. Erechim: FAPES, 2001; COSTA-ROSA, A. LUIZIO, C. A, e YASUI, S. Atenção Psicossocial: rumo a um novo paradigma na saúde coletiva. Achivos de saúde mental e atenção psicossocial. Coleção Archivos, Rio de Janeiro, v. 1, p. 13-44, jul. 2003.
} 
década de oitenta do século passado, realçando a desabilitação (redução das performances cognitivas e sociais) e a deficiência (desintegração social, perda de autonomia) que se seguem a um processo de sofrimento grave e persistente.

A reabilitação psicossocial seria, então, uma "estratégia global" que busca aumentar o poder contratual, aumentar a capacidade de realizar trocas, descobrindo e potencializando recursos nos diferentes cenários da vida, definidos pelo autor a partir de três eixos: do morar, das redes sociais (trocar as identidades) e do trabalho (produzir e trocar mercadorias de valor).

Se, conceitualmente assim foi colocada a reabilitação psicossocial, no plano da operacionalização dos serviços questiona-se sobre qual o sentido da reabilitação psicossocial diante de um lugar onde as trocas são minimas? Onde o espaço de negociação é quase inexistente considerando que a cultura corrente reifica a doença como matriz de todas as condutas institucionais. Nesse sentido, tem fundamento o questionamento e a constatação de Costa-Rosa et al. (2003), sobre o conceito de reabilitação: seria um velho significante, oriundo da prevenção terciária, para um conceito novo?

O crescente número de documentos relacionados à defesa dos direitos dos "usuários" de saúde mental nos últimos anos (alguns já citados aqui), parece sinalizar a privação a que são submetidas essas pessoas dentro e fora das instituições psiquiátricas. No plano federal foi aprovada a Lei de número 10.216 de 06/04/2001 (BRASIL, 2001) que dispõe sobre a proteção e os direitos das pessoas com transtornos mentais e redireciona o modelo de assistência em saúde mental, priorizando ações "extrahospitalares", preferencialmente, em serviços comunitários de saúde mental.

As atuais diretrizes municipais aprovadas na Conferência Municipal de Saúde trazem a implantação da Reforma psiquiátrica como eixo central. Para isso, propõe que o trabalho de saúde mental seja articulado em rede rede de atenção integral a saúde mental - e descentralizado junto às demais equipes e serviços de saúde das Unidades Básicas de Saúde distribuidas 
nos bairros. Tal documento deliberou também pela ampliação e criação de serviços especializados (Caps ou similares) em quatro regiões da cidade, que ofereçam retaguarda para toda a população, além do atendimento de urgência psiquiátrica nos hospitais gerais (CONFERÊNCIA MUNICIPAL DE SAÚDE, 4, 2003).

Os serviços que compõem o sistema municipal de saúde estão distribuídos conforme o mapa apresentado a seguir (mapa 1). As unidades de saúde, chamados na realidade local de "ambulatórios", ainda contam com poucos recursos humanos, materiais e de infra-estrutura. O Caps é o único do município, tendo dificuldades históricas para se constituir em lugar de referência e acolhimento às pessoas com sofrimento psíquico. Entre essas dificuldades está a questão do financiamento que, apesar do conjunto de normas e portarias estimulando os novos equipamentos para o redirecionamento do modelo de atenção, não foi ainda priorizado pela União, nem pelos Estados, ficando a cargo dos municípios a sua viabilização. $O$ município por sua vez, também lidou de forma precária com os seus recursos humanos, mantendo até o presente ano contratações terceirizadas, gerando dificuldades de permanência e vínculo dos profissionais no local, como bem retratou um dos seus "usuários": este é um lugar só de passagem para os profissionais.

O Caps é um serviço de atenção diária, com capacidade para atender em torno de 45 pessoas por dia e foi oficialmente credenciado no Ministério da Saúde na modalidade Caps II no final de 2002, funcionando como um centro de referência para a atenção básica de saúde que, segundo seu projeto de credenciamento, objetiva "oferecer aos portadores de sofrimento psiquico de Passo Fundo um espaço terapêutico, substituindo o modelo hospitalocêntrico [...]" (PASSO FUNDO, 2000). 


\section{Mapa 1 - Mapeamento dos serviços de saúde do município de Passo Fundo/RS}

\section{LEGENDA:}

Unidades de Saúde da Família e Ambulatơrios

- Centro de Atenção Psicossocial - CAPS

- Centro de Atenção Integral à Saúde CAIS

- Ambulatório Especializado em DST/Aids

- Posto de Atendimento Médico/Especialidades e Ambulatório de Dependência Química

- Centro de Saúde

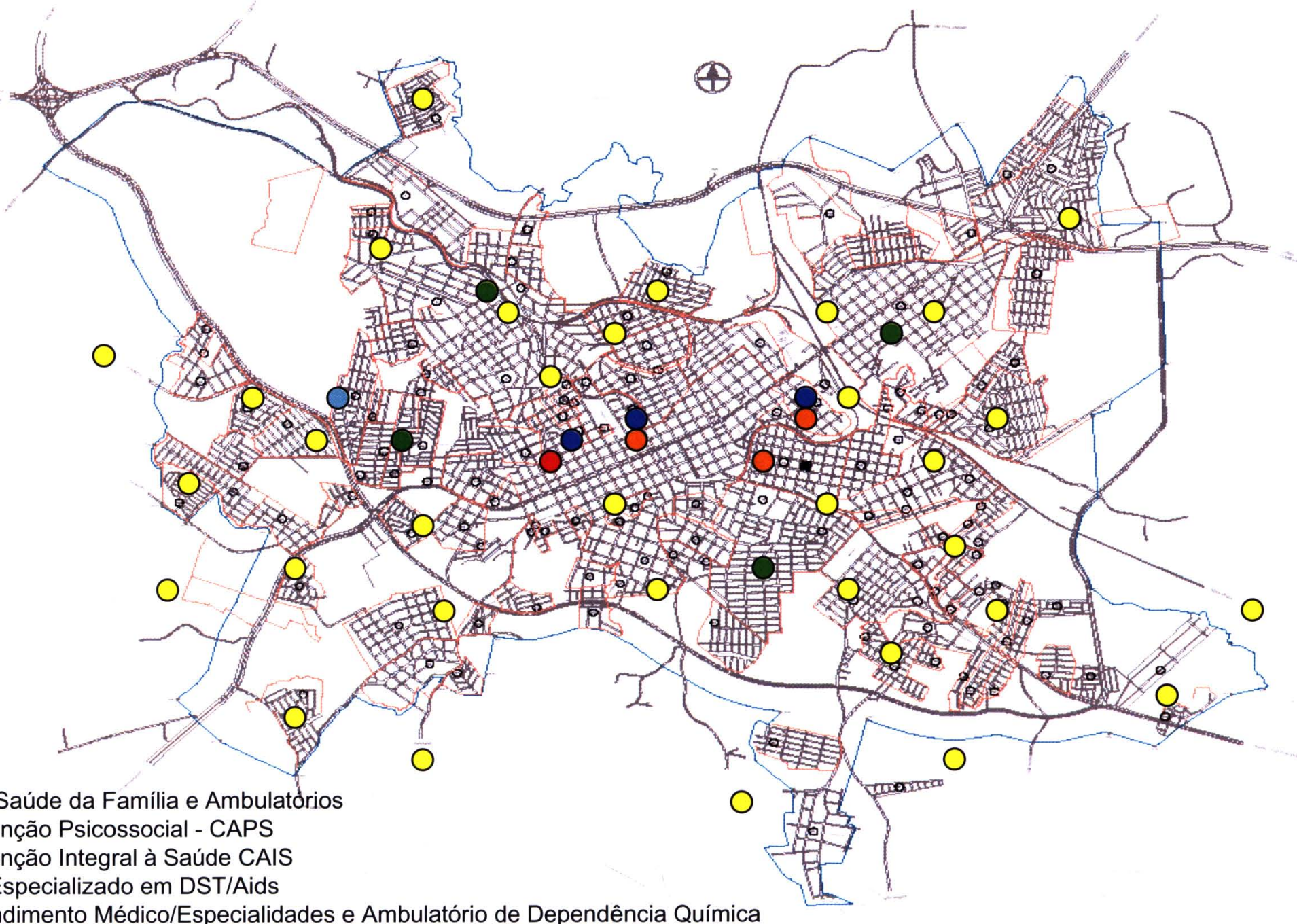


Realmente, os serviços pioneiros que deram origem a essa modalidade de assistência, a exemplo do Núcleo de Atenção Psicossocial de Santos $^{23}$ - São Paulo criado a partir de 1989 tinham o propósito de se constituir em espaços substitutivos ao tratamento psiquiátrico convencional, inspirados na crítica prático-teórica desse último e na necessidade de superação de toda uma cultura manicomial disseminada nos diferentes espaços sociais. Segundo essa proposta, o projeto institucional deveria privilegiar o olhar sobre o sujeito, compreendendo a doença como um elemento limitador da expressão da subjetividade e das potencialidades humanas, buscando ações que permitissem uma maior porosidade com o cotidiano, operando dessa forma também, "[...] rupturas conceituais, ao mesmo tempo que técnicas, políticas, jurídicas e sociais. Ao escutar, acolher, cuidar, interagir e inserir (ao invés de seqüestrar, disciplinar, medicalizar, normalizar) estão sendo construídas novas relações entre a sociedade e a loucura" (AMARANTE, 2003b).

Nessa mesma direção, Lobosque (2003, p.156) afirma que os serviços substitutivos serão novos "se, e apenas se, buscarem para o sofrimento psíquico grave um lugar de cidadania [...]. Serviços substitutivos são aqueles que se constituem enquanto rede: conjunto articulado de dispositivos e equipamentos, ações e iniciativas que possibilita a extinção do hospital psiquiátrico".

No entanto, apesar de todo o esforço para a construção de novas experiências centradas nos "usuários", na família e na comunidade, o que se pode captar é que na realidade local essas ações institucionais ainda são vagas, frágeis e distantes das complexas necessidades "psicossocias".

Embora a coordenação municipal de saúde mental oriente para que os "pacientes psicóticos" busquem atendimento nas Unidades de Saúde e

\footnotetext{
${ }^{23}$ Parte do projeto original do NAPS de Santos e do CAPS professor Luis da Rocha Cerqueira são analisados por Amarante e Torre (2001). Os autores destacam que as portarias ministeriais que instituíram e regulamentaram os NAPS/CAPS (especificamente as 189/1991 e 224/1992), ainda que tenham viabilizado a construção de novos serviços, produziram uma homogeneização das experiências originais. Uma das definições centrais que não incorporou tais documentos foi o caráter "substitutivo" desses serviços; em seu lugar foram definidos como espaços intermediários entre o nivel ambulatorial e hospitalar.
} 
no Caps, tendo como referência para situações de emergência o pronto atendimento dos hospitais gerais; também diz que não tem condições de atender pessoas em crise nesses locais, sendo necessário o encaminhamento hospitalar: temos orientado os usuários a buscarem o hospital da cidade que tem na sua estrutura o hospital psiquiátrico e assim facilita o fluxo a esse quando necessário ${ }^{24} .0$ município, responsável pela gestão da saúde, não construiu as condições técnicas, políticas, físicas, etc. para acolher a pessoa em situação de crise, nem nas Unidades de Saúde, nem no Caps, tampouco nos hospitais gerais, e, portanto, enxergando como a saída, a internação psiquiátrica.

Observamos que, se necessário, familiares e "usuários" iniciam um longo percurso pela cidade, passando de serviço em serviço, sendo por fim conduzidos à internação psiquiátrica. Se a legislação preconiza que devam ser esgotados todos os serviços extra-hospitalares, não é o que ocorre no município de Passo Fundo. A orientação para acesso a esses serviços não é clara na política local, está distante de uma articulação em rede que se responsabilize pelo trânsito do seu usuário, corroborando a idéia de um caminho já conhecido e central: lugar de louco é no Bezerra!

As informações sobre internações psiquiátricas foram coletadas em estudo realizado na região da $6^{\mathbf{a}}$ Coordenadoria Regional de Saúde de Passo Fundo no ano de 1999, quando constatamos que $99 \%$ das internações ocorreram em hospitais, ou clínicas psiquiátricas, e apenas $1 \%$ em hospitais gerais, o que torna clara a centralidade do atendimento em hospitais específicos em psiquiatria e o baixo investimento no leito do hospital geral (DALMOLIN et al., 1999).

É oportuno destacar que o leito ou unidade psiquiátrica no hospital geral teve início no Brasil na década de 1950, e entre as principais razões de seu surgimento estavam as possibilidades de melhorar a terapêutica dos pacientes, oferecendo-lhes outras abordagens e reduzindo a segregação e

${ }^{24}$ Informações obtidas junto a Coordenação da Política de Saúde Mental do município em $29 / 10 / 2003$ 
estigmatização por que passavam os sujeitos internados nos hospitais psiquiátricos.

Além disso, ao compararmos o número de internações hospitalares no município nos anos de 1999 e 2001, verificamos que não houve alteração expressiva no período, sendo que ocorreram 469 internações em 1999 e 441 no ano de 2001 (SIH-SUS, 2002), o que fortalece a interpretação de que esse processo não tem se modificado no município no decorrer do tempo.

Essas mesmas questões também repercutem no cotidiano da Promotoria Pública da cidade. Ao referir-se às mudanças da legislação sobre a pessoa com "patologias mentais", o promotor ${ }^{25}$ que lida mais diretamente com as questões de saúde destaca que a nova filosofia procura romper $o$ modelo manicomial [...] exatamente com o objetivo de manter o vínculo familiar que é muito importante para o tratamento dessas pessoas. Recupera do Alienista de Machado de Assis os mansos da casa verde que andavam pelo pátio e eram pessoas do mesmo jeito que podiam viver na sociedade. São pessoas que estão no seio da sociedade e que tem que viver aqui. Então, na verdade, nós temos de assumir isso.

Por outro lado, o mesmo promotor, não deixa de apontar os limites da implementação desse modelo de atenção: essa é uma questão de saúde publica e não de segurança pública! Ressalta as dificuldades da política pública local em cumprir as determinações da lei.

Se, por um lado, os hospitais gerais que deveriam abrir um percentual [...] de leitos para internação de pacientes na área da saúde mental não fizeram isso, e é muito dificil você conseguir internar.

Por outro lado, encontro imensa dificuldade quando não há necessidade de internação, só de um acompanhamento, por exemplo. As pessoas poderiam ser identificadas perfeitamente pela saúde pública do município,... tem fulano, sicrano e beltrano e o município tem que saber mapear, localizar e acompanhar essas pessoas, isso não seria difícil até porque o municipio tem ambulatórios espalhados pelos bairros (grifo nosso).

\footnotetext{
${ }^{25}$ Ator institucional que entrevistei em decorrência da pesquisa.
} 
O Promotor capta e explicita de maneira precisa o sentido da "rede de atenção à saúde mental" que, juntamente com outras - reforma psiquiátrica/atenção psicossocial -, passa a ser citada nos planos das instituições, quase que como uma transcrição da lei, como se acontecesse de forma automática, sem negociação e sem investimento, principalmente de pessoal.

O que observo é que a atenção à saúde mental do município continua circunscrita principalmente às quatro paredes do hospital psiquiátrico e do Caps sem um aprofundamento da/na realidade local, do processo saúde-doença mental, sobre a repercussão das tradicionais formas de atenção em relação à vida dos sujeitos e, principalmente, sobre possibilidades que poderiam expandir suas vidas.

A importância de um trabalho em rede é indiscutivel, tanto em relação às redes de serviços de saúde, quanto às demais redes sociais que construímos nas mais diversas situações de vida, particularmente se entendermos que o homem não é uma doença, uma crise existencial, mas um ser "complexo" que exige mais do que ações solitárias e setoriais, aspectos essenciais para um trabalho de atenção psicossocial e para a compreensão da vida. É dessa perspectiva que se colocam os serviços de saúde de base territorial. No sentido dado pelo geógrafo Milton Santos (2002, p.70), o "território" é produzido no decorrer da existência por um conjunto articulado de referências culturais, sociais, econômicas, políticas, afetivas,... sendo a "base material sobre a qual a sociedade produz sua própria história. Como tal, torna-se o melhor "observatório" do que ocorre na cidade ou no pais.

Essas idéias estão intimamente ligadas à noção de pertencimento da cultura local, onde as pessoas vivem e negociam seus espaços de subordinação e liberdade, um campo concreto de tensões e possibilidades "[...] com todos os que nele habitam e transitam, seus signos e significados, a melhor nomeação para um terreno sobre o qual uma rede de iniciativas 
múltiplas agenciam cuidados de saúde e inclusão social" (PITTA, 2002, p.23).

Mas, como afirma Milton Santos (2002), o território vai sendo "moldado por quem manda" e, nesse sentido, é preciso refletir sobre a presença de um saber centralizador que não se inscreve apenas nas instituições de saúde mental, mas que deu origem a elas e se dissemina nas mais diversas práticas de saúde, recriando circuitos e atravessando outros espaços da esfera social, em formas mais sutis e complexas de dominação e exclusão. Essa constatação aparece no relato de João-de-Barro e parece representativa de um modelo que determina um trajeto linear e um lugar "congelado" para a loucura, negando-lhe possibilidades de expansão. Vamos ouvi-lo:

\footnotetext{
Eu queria continuar meus estudos pra tentar fazer alguma coisa depois, pois sou novo ainda e tenho um filho pra criar. Fui até a escola para ver o que eu precisava para me inscrever no supletivo do primeiro grau. Conversei com a diretora, peguei todas as informações. Quando voltei para fazer a matricula ela veio com a seguinte conversa: "Tu não é aposentado por invalidez?" Falei que sim e expliquei o meu problema, ai ela me aconselhou a não estudar, porque eu poderia perder a aposentadoria...
}

A política de saúde mental colocada em pauta (através do "movimento" pela reforma psiquiátrica, expresso nas Conferências de Saúde Mental e incorporada, em parte, pelo Ministério e Secretarias de Saúde) transcende as questões mais restritas ou tradicionais da assistência à saúde (remédio, internação ou outras técnicas terapêuticas mais modernas) ou de uma reorganização dos serviços (abertos, comunitários, intensivos, fechados), uma vez que o sujeito que adoece psiquicamente tem afetado quase todos os aspectos de sua vida - o profissional, o pessoal, o familiar, o intelectual, o afetivo, enfim, o conjunto de suas relações. A melhora dos sintomas, a saida da crise, não lhe garante uma melhora nesses aspectos, mesmo que a "incapacidade ou limitações" seja mínima, porque existe uma construção social do/sobre o "doente mental" (compactuada por boa parte dos próprios profissionais de saúde) que o coloca no lugar de excluído do 
mundo da cidadania, à margem da sociedade, como no exemplo da professora que usou de um subterfúgio - a aposentadoria - para dificultar ou impedir o depoente de retornar à escola. Assim, esse "sujeito" pode tornarse um "improdutivo social", alguém em quem a sociedade não tem mais interesse em investir. Além disso, é tido como "perigoso", "desprovido de razão" e, portanto, visto como alguém que precisa ter sua liberdade cerceada, pelo menos em determinados momentos.

Pensar em um modelo pautado na reforma psiquiátrica requer colocar questões como as do lugar social do sujeito em sofrimento psíquico, suas potencialidades e possibilidades, sua autonomia diante da vida e sua diferença, no centro de nossas discussões, enquanto trabalhadores de saúde mental. Esse modelo requer ainda a proposição de práticas em diferentes niveis, numa negociação permanente com os diferentes atores sociais, capaz de produzir outras possibilidades de vida mais inclusivas, e mais dignas da condição humana.

Percebe-se que essas questões têm sido insuficientemente discutidas pelos trabalhadores das instituições de saúde mental do município de Passo Fundo, até porque discutir essa questão colocaria necessariamente o modelo vigente em crise. Essa postura, explicitada nas "recomendações" de alguns colegas de trabalho - não tinha alguém melhor pra você estudar? O que você vai conseguir do fulano com essa estrutura psicótica? - reforça o lugar do sujeito que vive a experiência do sofrimento psíquico como alguém que, pouco ou nada pode nos dizer, nos ensinar; alguém cujo investimento, afeto e oportunidade, parecem ter ficado para trás.

Depois de idas e voltas de supervisão, de reflexões, de sofrer com o sofrimento do outro e com os meus próprios, é que me decidi a enfrentar o desafio de aprofundar a singularidade desse sujeito na inserção social e cultural, explorando os aspectos que o faz ainda resistir e dizer: eu não quero mais ficar aqui! Não quero voltar pro Bezerra, nunca mais! 
Em meio a esta trama surgem outros questionamentos a balizar este estudo: que outros modos de vida cotidiana podem fazer frente a recursos tão uniformizadores quanto os ainda presentes nas "práticas" psiquiátricas? Que estratégias as pessoas que experienciam o sofrimento psíquico e seus familiares vão construindo para lidar com as suas necessidades? Em que momento/circunstâncias a situação de sofrimento psíquico passa a não mais ser tolerada pelos familiares, pelo próprio sujeito e/ou pela comunidade e se transforma em "demanda" de assistência na rede formal de saúde? 


\title{
CAPITULO II - A CONSTRUÇÃO DE UM CAMINHO METODOLÓGICO
}

\begin{abstract}
Certa vez, num de meus passeios, ao entrar na praia encontrei várias pegadas na areia, as quais formavam várias trilhas.

Escolhida uma, passei a seguil-la, colocando meus pés exatamente sobre as marcas que ali se encontravam. Em tal empreendimento, entretanto, defrontei-me com algumas dificuldades: 1) na medida em que seguia a trilha, sentia um certo desconforto, desequilibrando-me em certos momentos, pois o "balanço" daquele que ali deixou sua marca era diferente do meu, e aí percebi que eu não conseguia andar como ele; 2) outra dificuldade se referia à escolha da trilha a ser seguida, pois não havia um encontro perfeito entre o meu pé com a marca escolhida, o que caracterizava, ainda mais, a nossa diferença. Após caminhar alguns metros - pé ante pé sobre as marcas - olhei para trás e vi que as pegadas iniciais - aquelas que escolhera para seguir - já não existiam mais, elas desapareceram; e o que ficou inscrito na areia não eram nem as minhas pegadas, nem as pegadas do indivíduo que ali passou anteriormente, mas o produto de nossa relação.
\end{abstract}

(MARTINS, 2000)

\subsection{A escolha do caminho metodológico}

A escolha de um caminho metodológico depende, como se sabe, do objeto de pesquisa e do enfoque ou lugar de que desejamos abordá-lo. Nesta pesquisa, desde o início, manifestei o desejo de entender a dinâmica que se processa no cotidiano de pessoas que vivem e convivem com o sofrimento psíquico e, portanto, senti-me desafiada a tentar reconstruir uma situação que não é visível, em um campo ainda pouco conhecido por nós.

Os trabalhos que envolvem essa temática parecem se inscrever, predominantemente, em vertentes biomédicas, excluindo outras óticas, o que limita o desvendamento de aspectos relevantes na constituição do sujeito. Alia-se a esse olhar, a preponderância desta vertente no discurso dos profissionais que, através do poder que detêm, seja ele técnico, politico ou administrativo, muitas vezes, restringem 0 acesso e fecham a possibilidade de percebermos o sujeito como o outro, nas suas dimensões históricas, culturais e psicológicas. 
No que se refere a esse olhar, vale registrar o trabalho que desenvolvi na gestão pública ${ }^{26}$, antes do doutorado. Tratava-se de um trabalho de apoio aos municípios, a fim de que desenvolvessem políticas de saúde mental voltadas ao cumprimento da lei de reforma psiquiátrica do Estado. Foi um lugar de fortes embates por envolver decisões sobre a manutenção de instituições já existentes, a necessidade de adequar estas instituições a normas e protocolos, de ampliar e qualificar o acesso dos usuários e de viabilizar novos serviços para compor redes regionalizadas $e$ municipais de saüde mental. Neste trabalho, tive de administrar conflitos entre o conjunto de segmentos que compõem o campo da saúde mental; muitas vezes vistoriando serviços, solicitando ajustes, propondo ou vetando credenciamento de determinados estabelecimentos. Enfim, tive de tomar decisões nem sempre agradáveis a todos, mas necessárias ao exercício de determinadas funções do Estado.

Esta experiência contribuiu, e muito, para o meu trabalho de pesquisa. Percebi ali que, no contexto da vida "real", as pessoas buscam protagonizar trajetórias, criam estratégias, produzem um saber que, via de regra, sequer é percebido ou valorizado pelos profissionais e serviços que lidam com elas. Quando chegam ao serviço, estas pessoas parecem saber o que pode ou não, o que vai ser valorizado ou não, naquele local. Por isso, agem também segundo o que pensam que se espera delas, deixando de explicitar os recursos próprios e de seu contexto, mascarando assim, a sua própria singularidade.

É nesse sentido que as pesquisas realizadas no interior das instituições, parece-me, apresentam mais dificuldades em apreender os imponderáveis do cotidiano. Aqui, vale lembrar Vasconcellos que enfatiza a riqueza do periodo em que os sanitaristas usavam as ruas, as praças buscando compreender os hábitos, a cultura, os valores da população e, portanto, respondendo em parte, a este processo de apreensão do cotidiano:

26 Fui integrante da equipe de gestão da $6^{a}$ Coordenadoria Regional de Saúde da Secretaria Estadual de Saúde do RS, nos anos de 1999 e 2000. A coordenação de minha responsabilidade era a Atenção Integral à Saúde - CAIS. A regional é composta de 58 municipios na região norte, com sede em Passo Fundo. 
[...] mas, fundamentalmente, é fora delas (das escolas de Saúde Pública) que se dará a lição de compreender sob as condições históricas e a partir das diversas ideologias presentes como agir sobre as condições sócio-sanitárias que poderão ameaçar a saúde da população. Por isso, os sanitaristas devem estar onde o povo está e recolocar no centro de suas preocupações as pessoas e seus modos de vida, suas produções materiais e simbólicas, suas formas predatórias de agir (2000, p.141).

Por isso, meu esforço foi o de "distanciar-me" do institucional, o mais possivel, tentando escapar das "armadilhas" institucionais e aproximar-me do ponto de vista dos sujeitos que vivem o sofrimento, com vistas a ampliar minha compreensão do problema relativo ao sofrimento psiquico.

Sendo assim, o desenvolvimento deste estudo fora das instituições que oferecem serviços de saúde mental no município é, também, um exercício para sair do nosso percurso cotidiano que muitas vezes nos impede de compreender melhor a experiência do outro que vive/convive com o sofrimento psíquico. Nossa intenção não é a de negar a importância e a necessidade de estudos ${ }^{27}$ sobre os contextos institucionais. Apenas preferimos nos situar fora deles, pois entendemos que aqui, no contexto das condições concretas vividas e construídas no "território", apreenderemos de um outro lugar, a singularidade e as condições de saúde dos que sofrem psiquicamente.

A construção do objeto de pesquisa trouxe a opção pela pesquisa qualitativa uma vez que nos parece a mais apropriada para a compreensão do campo das relações que perpassam o cotidiano da vida dos sujeitos portadores de sofrimento psíquico. Conforme González Rey (2002, p.51), a pesquisa qualitativa no campo da psicologia apresenta elementos que "são implicados simultaneamente em diferentes processos constitutivos do todo, os quais, mudam em face do contexto em que se expressa o sujeito concreto".

\footnotetext{
${ }^{27}$ Madel Luz (2000) faz uma análise da produção científica nas três últimas décadas do século passado, destacando a área da saúde. Neste trabalho a autora refere-se às práticas cotidianas institucionais e às micro relações sociais como motivadoras, até então, secundariamente, do campo.
} 
Nesse processo recorri, inicialmente, à abordagem etnográfica. Embora "estrangeira" nesse campo, entendi que esta opção metodológica ser-me-ia útil pela sua tradição em estudos que privilegiam a compreensão dos padrões culturais do outro.

Além das observações sistemáticas, conversas e relatos, também trabalhamos com documentos oficiais das instituições: Projetos Terapêuticos do Hospital, Projeto do Caps - Centro de Atenção Psicossocial, Processos judiciais, SIH/SUS, recortes de jornais locais e entrevistas com alguns atores institucionais, como foi o caso da entrevista com o promotor de justiça e com a defensora pública ${ }^{28}$.

\subsection{A contribuição da antropologia na compreensão teórica do objeto}

Para compreender o objeto de pesquisa, entendi que seria necessário aprofundar o estudo dos aspectos culturais dos pesquisados e, por isso, recorri à antropologia cujas "contribuições", pensei, poderiam me aproximar da dinâmica cotidiana desse grupo social, apreendendo códigos ainda pouco conhecidos, modos de vida, arranjos e rearranjos propiciados por uma situação especial, como também poderia romper com visões desatentas e por que não, preconceituosas, que orientam e conduzem o nosso olhar técnico. Conforme Magnani (2000, p. 21), "é esse jogo de espelhos, é essa imagem de si refletida no outro que orienta e conduz o olhar [...]", auxiliando-nos num mergulho necessário para buscar significados onde, muitas vezes, só se via a anormalidade, a doença, a periculosidade.

Como foco de interesse, a antropologia busca compreender o outro através das estruturas e das relações sociais, ou seja, em análises microssociais, colocando como especificidade do estudo a diversidade e a alteridade. Para o que nos interessa, procura "entender o significado específico que esses fenômenos (psíquicos) assumem numa dada

\footnotetext{
${ }^{28}$ Os documentos das instituições de saúde que não eram de domínio público foram autorizados por meio de "Termo de Autorização" assinado pelo responsável da instituição (anexo 1). Os atores institucionais e protagonistas também assinaram "Termo de Consentimento" para a cessão e uso das entrevistas (anexo 2).
} 
sociedade, visto que os registros de normalidade e anormalidade são, antes de tudo, determinados a partir de valores" (VICTORA et al., 2000, p.11).

Enquanto categoria fundamental nesse campo, a cultura "deve ser entendida como o conjunto de regras que orienta e dá sentido às práticas $e$ à visão de mundo de um determinado grupo social" (VICTORA et al., 2000, p.13). Em sua obra Interpretação das culturas, Geertz (1989) afirma que a cultura é produzida pelas pessoas nas relações que estabelecem, em determinadas circunstâncias, dentro de seu universo de interpretações e de acordo com o qual realiza ações. A importância de enfocar os referenciais adquiridos em experiência por uma determinada cultura está justificada no fato de que é no ordenamento e no acúmulo desses "padrões culturais" que as pessoas encontram sentido para os acontecimentos da vida.

Assim, podemos dizer que a antropologia, particularmente a que se dedica ao estudo das sociedades complexas, possibilita diferentes leituras sobre o outro que, embora vivendo, muitas vezes, no mesmo espaço geográfico em que vive o pesquisador, detém especificidades sócio-culturais passiveis de serem investigadas.

Construir relações entre cultura e saúde mental tem sido desafio constante para os pesquisadores e profissionais da saúde. Entre outras questões esse desafio deve-se ao fato de que os conhecimentos sobre determinada cultura exigem do pesquisador, aproximação e aprofundamento na compreensão dos códigos que perpassam as relações estabelecidas no meio cultural, além da aceitação das experiências vividas e expressas nessas relações de tal modo a evitar que sejam enquadradas a partir de uma só perspectiva.

Assim, o local de moradia, a história do sujeito, suas redes sociais, as instituições enfim, compõem o cenário do estudo, pois este processo, constituinte da experiência de vida das pessoas, repercute na sua condição de saúde/doença mental. Conhecer essas pessoas acaba sendo uma experiência intersubjetiva "que conduz à revisão do sentido dado às coisas, podendo corresponder à necessidade de se situar, de achar um espaço 
específico na multiplicidade de espaços presente na contemporaneidade fragmentada" (ADORNO; CASTRO, 1994, p.182).

Magnani (2002) em seus estudos sobre a vida urbana propõe que se compreenda a cidade a partir de uma perspectiva antropológica que apreenda o significado da rede de relações sociais que ele chamou de olhar de perto e de dentro em oposição a outros tipos de abordagem da questão urbana, abordagens essas, homogeneizadoras da vida social e impeditivo do processo de apreensão das especificidades de atuação dos atores sociais em seus múltiplos espaços, ou, o que Magnani (2002) denominou de olhar de longe e de fora.

Enquanto particularidade da antropologia, o método etnográfico:

[...] não se confunde nem se reduz a uma técnica, pode usar ou servir-se de várias, conforme as circunstâncias de cada pesquisa: ele é antes um modo de acercamento e apreensão [...] a natureza da explicação pela via etnográfica tem como base um insight que permite utilizar dados percebidos como fragmentários, informações ainda dispersas, indícios soltos, num novo arranjo, que não é mais o arranjo nativo, mas que parte dele, leva-o em conta, foi suscitado por ele, nem aquele com o qual o pesquisador iniciou a pesquisa (MAGNANI, 2002, p.17).

Para Malinowski (1980, p.47), toda (essa) estrutura "encontra-se incorporada no meio mais evasivo de todos os materiais: o ser humano". No entanto, nem para os nativos de uma dada comunidade esses aspectos são, na maioria das vezes, compreensíveis, pois são "um resultado automático da interação das forças mentais da tradição e das condições materiais do meio".

Sob a óptica da etnografia, um novo arranjo é possibilitado pelo confronto entre as construções do pesquisador e dos pesquisados, participantes de um mesmo plano, o que exige a transformação de ambos, através de um processo de trocas, como bem simboliza o diário de Martins, na epígrafe deste capítulo. Ou, como diz Magnani (2002, p.17): "Ambos são dotados dos mesmos processos cognitivos que lhes permitem, numa instância mais profunda, uma comunhão para além das diferenças culturais". 
Nesse sentido, o pesquisador precisa construir um lugar de participação no grupo, de tal modo que sua presença seja aceita e consentida, mas, ao mesmo tempo, cuidar para não se deixar absorver por ele, de modo a naturalizar as relações e práticas. Este lugar, parece-me, é um lugar pouco preciso em que o pesquisador está sempre implicado na tensão de seu próprio pensamento, de sua própria subjetividade construindo relações intersubjetivas com os protagonistas.

O desafio foi olhar os sofredores psíquicos "de outro lugar", a fim de vermos outros arranjos, para além de visões homogeneizadoras e, recorrendo para tanto, ao poder e à categoria dos "nativos".

Essas reflexões metodológicas foram de fundamental relevância para nossa pesquisa. Por meio delas pudemos avançar na compreensão dos arranjos que os sujeitos vão criando no convivio com a situação de vida do sofrimento psíquico que uma outra direção metodológica pode considerar como uma trajetória sem lógica, com poucas conexões, balizada pelos "ruídos" produzidos pela doença.

Brandão (1995, p.138-139) refere-se ao cuidado na elaboração do trabalho de cunho etnográfico para não congelarmos a vida interpessoal na estrutura social, pois o que se perde é mais do que a experiência da vida cotidiana:

[...] perde-se também a compreensão que as lógicas das estruturas das relações entre familiares, entre parentes [...], entre vizinhos, entre tipos de sujeitos produtivos e/ou proprietários, entre patrões e empregados, entre homens e mulheres, entre nós e entre nós e os outros, existem não somente dentro e entre as tramas de teias de instituições sociais [...] através das quais se trabalha, possui, produz, gera filhos, herda, etc., mas igualmente através de outras teias que tecem as vidas e, dentro, fora, a margem ou contra as organizaçōes oficiais da sociedade, geram os sistemas de vida, os símbolos e os significados de outra face da própria vida.

Pode-se afirmar que a cidade/bairro deste estudo, embora de características "interioranas", guardadas as proporções, também sofre os reflexos do processo urbano e global das grandes cidades. Assim, a lógica de suas relações sociais a partir de códigos particulares e percursos 
específicos só pode ser entendida no desenrolar do cotidiano, mergulhandose no universo cultural que the dá sentido. Dessa forma, retomando Magnani (2002), a complexidade desses espaços "já não constitui uma totalidade operacional", sendo "preciso estabelecer mediações entre o nível das experiências dos atores e de processos mais abrangentes", de modo a se obter algum ordenamento entre as práticas especificas $e$ os comportamentos que se evidenciam. Para isso o autor propõe, a partir de pesquisas na metrópole paulista, uma estratégia - a familia de categorias ${ }^{29}$ composta pelo pedaço, mancha, trajeto, circuito e pórtico que permitem fazer articulações e possibilitam análises do espaço urbano. Estas categorias são - "resultado do próprio trabalho etnográfico, que reconhece os 'arranjos' nativos, mas que os descreve e trabalha num plano mais geral, identificando seus termos e articulando-os em sistemas de relações" (MAGNANI, 2002, p.20).

Dessa família de categorias e, para o que nos interessa, destacamos as idéias de circuito e trajeto. Os circuitos descrevem "o exercício de uma determinada prática ou oferta de determinado serviço por meio de estabelecimentos, equipamentos e espaços que não mantêm entre si uma relação de contigüidade espacial, sendo reconhecido em seu conjunto pelos usuários habituais". Os trajetos são escolhas específicas dos sujeitos, "fluxos recorrentes no espaço mais abrangente da cidade", seguindo algum curso de preferências (primeiro, depois, em seguida,...) ou de uma determinada especialidade (MAGNANI, 2002, p.23).

Foi com base nessas contribuições da etnografia e da compreensão do fenômeno urbano, ressignificadas diante de nosso contexto e objeto de pesquisa que procuramos construir o campo de investigação. Descrevo, mais adiante, como desenvolvi as sucessivas etapas, buscando estabelecer mediações entre as relações cotidianas das pessoas em sofrimento psíquico e o espaço da cidade, de modo a cartografar os percursos e as práticas recorrentes que se estabeleciam no dia-a-dia de nossos protagonistas.

${ }^{29}$ Sobre a familia das categorias ver MAGNANI e TORRES (2000); MAGNANI (1999) e MAGNANI (2002). 
Mesmo reconhecendo o risco das limitações de quem é de fora, assumimos o desafio de nos servirmos da etnografia, buscando nela subsídios que nos possibilitassem exercitar um olhar especifico sobre nossa temática, questionando nossas práticas e envolvendo-nos, de um modo diferente dos que, usualmente, adotamos nas pesquisas relacionadas à área de saúde.

\subsection{Ponto de partida da pesquisa: o bairro Vera Cruz}

Passo Fundo é um município do interior do Estado do Rio Grande do Sul, localizado no planalto médio, a uma distância em linha reta de $225 \mathrm{~km}$ da capital (Porto Alegre), com uma extensão geográfica de $780.355 \mathrm{~km}^{2}$ e com uma população total de 168.458 habitantes. Desses, 163.764 residem na zona urbana e 4.694 na zona rural, sendo 80.766 habitantes do sexo masculino e 87.692 habitantes do sexo feminino. É considerado pólo regional em prestação de serviços nas áreas da saúde, educação e comércio (IBGE, Censo 2000). 
Mapa 2 - Estado do Rio Grande do Sul

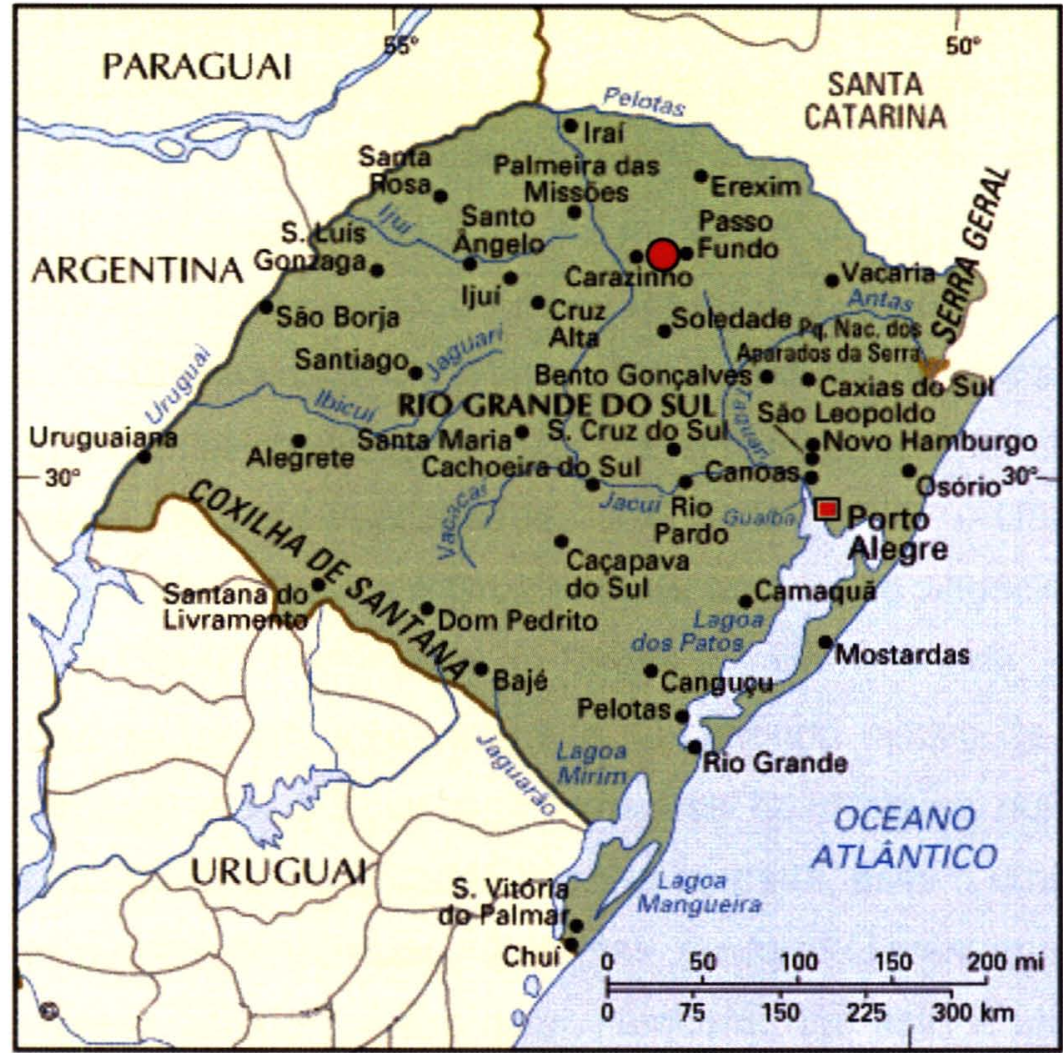

Fonte: http://www.guianet.com.br/rs/mapars.htm, 2004.

Mapa 3 - Município de Passo Fundo/RS.

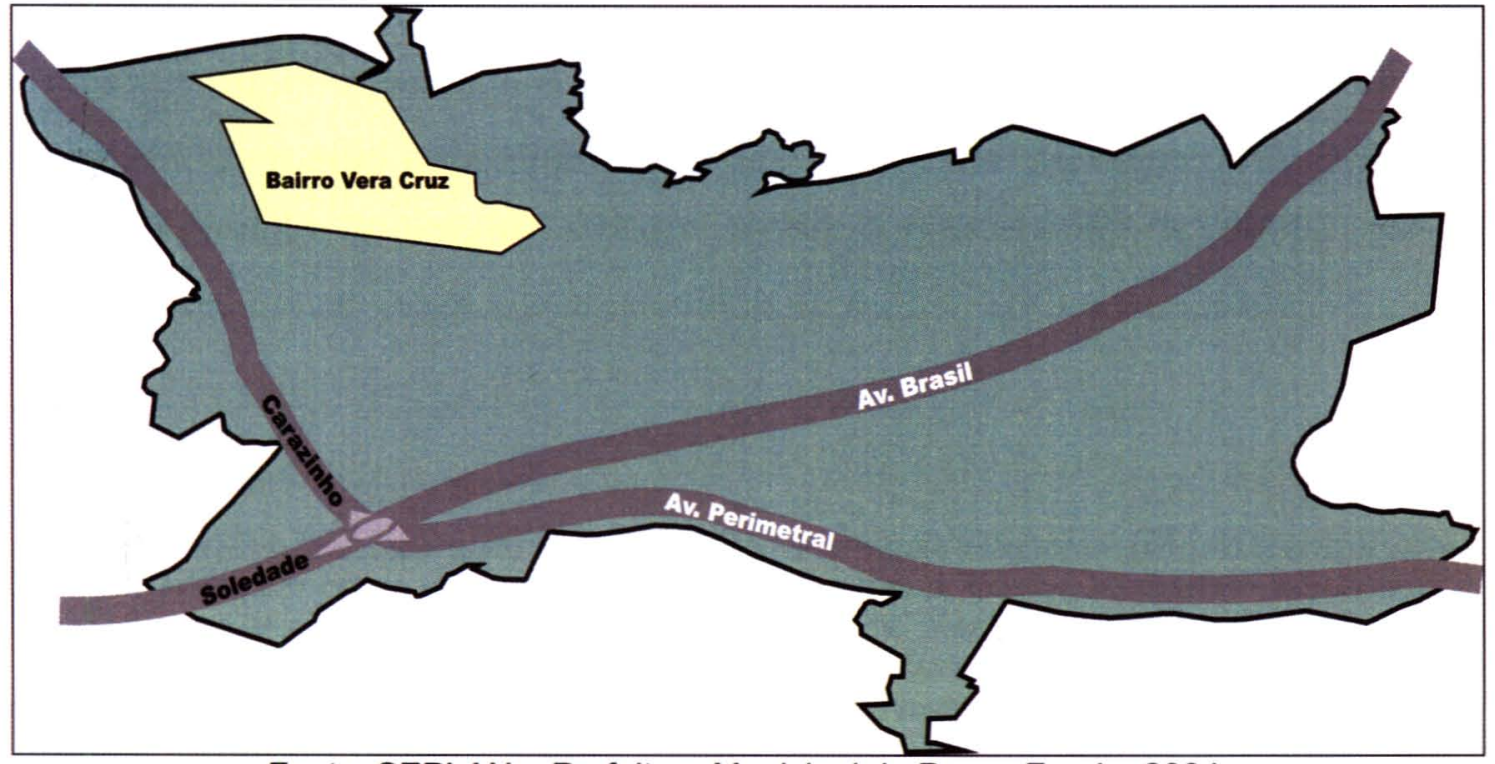

Fonte: SEPLAN - Prefeitura Municipal de Passo Fundo, 2004. 
O espaço de onde partimos e desenvolvemos grande parte do nosso trabalho, o bairro Vera Cruz, foi escolhido por dois motivos. O primeiro refere-se ao fato de que algumas disciplinas do curso de enfermagem se servem do bairro para a realização de trabalhos acadêmicos comunitários. Isto se deve a uma discussão, ou muito mais que isso, ao desejo de alguns docentes da Universidade de Passo Fundo (UPF) de extrapolarmos os "muros" do hospital-universitário para nos aproximarmos da situação vivida pelas pessoas nas suas comunidades. A entrada da UPF - Universidade de Passo Fundo - no bairro Vera Cruz ocorreu através de negociações entre a Secretaria, o Conselho Municipal de Saúde e a Universidade, embora ainda se trate de uma participação incipiente. O segundo motivo da escolha está relacionado aos altos índices de internações hospitalares por "transtornos psíquicos" nessa área de abrangência. Na verdade, essa é uma das regiões com maior número de pessoas internadas, conforme levantamento realizado para fins desse estudo ${ }^{30}$. Cabe dizer, também, que este é um dos bairros mais antigos e populosos da cidade.

Para conhecer um pouco mais do bairro, recorri às conversas com moradores mais antigos, aos mapas da Prefeitura Municipal e as minhas observações e relatos de campo. Assim, ainda que parcialmente, pude saber: quem eram esses moradores, de onde vinham, o que buscavam nesse local. Não encontrei outras referências que pudessem me auxiliar no mapeamento do bairro, embora tenha conhecimento de outros estudos urbanos relacionados à vida cotidiana de outros bairros da cidade ${ }^{31}$.

\footnotetext{
${ }^{30}$ Em análise realizada junto ao Sistema de Informação Hospitalar (SIH-SUS), nos anos de 2000-2001, por bairro no município, identificamos que a "grande Vera Cruz" apresentava os maiores números de internação por "Transtornos Mentais". Essas informações foram elaboradas a partir de estimativas populacionais (dados fornecidos pelo IBGE, 2000), pois até o momento não existe lei municipal que cria e delimita os bairros e, portanto, o próprio IBGE não conseguiu disponibilizar essas informações.

${ }^{31}$ Maciel (2001) escreveu: Gênero, trabalho e familia: a construção de espaços femininos na periferia urbana. Desenvolvido no bairro São José/PF, a autora descreve as origens rurais do grupo estudado e "as andanças" em busca de emprego. Benicá (1991) organizou a coletânea: Religiosidade \& saúde popular, estudo relacionado a alguns bairros do município de Passo Fundo.
} 
Para uma melhor compreensão do que seja bairro, valemo-nos de Certeau et al. (2000, p.42) que diz:

O bairro constitui um termo médio de uma dialética entre o dentro e o fora. E é na tensão entre esses dois termos, um dentro e um fora, que vai aos poucos se tomando um prolongamento de um dentro, que se efetua a apropriação do espaço. Um bairro, poderse-ia dizer, é assim uma ampliação do habitáculo; para o usuário, ele se resume à soma das trajetórias inauguradas a partir do seu local de habitação. Não é propriamente uma superfície urbana transparente para todos ou estatisticamente mensurável, mas antes a possibilidade oferecida a cada um de inscrever na cidade um sem-número de trajetórias cujo núcleo irredutivel continua sendo a esfera do privado.

Em minha primeira incursão ao Vera Cruz obtive informações mais gerais sobre demografia e estrutura local. Trata-se de um bairro de "classe média baixa"32, com cerca de 6.500 familias tendo, em média, cinco pessoas por familia e perfazendo um total de aproximadamente 30 mil habitantes ${ }^{33}$. É considerado pelos seus moradores como um bairro praticamente autônomo do centro da cidade por abrigar comércio diversificado, indústria, escolas (de primeiro e segundo graus e escola técnica), unidades de saúde, casas bancárias. A maioria dos moradores trabalha no próprio bairro que abriga uma unidade das mais importantes indústrias da cidade - a Semeato produtora de maquinários agrícolas. Na entrada, (sentido centro-bairro) está localizado o maior cemitério da cidade e nos extremos mais afastados do centro encontram-se diversas vilas menores que, no conjunto, compõem a "Grande Vera Cruz".

Foi um espaço que abrigou muitos migrantes de cidades circunvizinhas oriundos da área rural. Na verdade, o fluxo migratório no Vera Cruz mantém-se até hoje, embora sua "ocupação"/povoamento tenha-se se iniciado há mais de meio século, conforme relato de uma das moradoras, aliás, uma das primeiras pessoas a habitar o local:

\footnotetext{
${ }^{32}$ Classe média baixa é uma classificação vinda dos meus informantes para caracterizar, em especial, as condições econômicas dos moradores do bairro.

${ }^{33}$ Dados obtidos junto a Secretaria da Administração do municipio de Passo Fundo/RS em setembro de 2001.
} 
Dona Bernardina mora há sessenta e três anos no bairro, desde quando ainda chamava-se Capão do Bugio, um espaço que possibilitava a extensão de suas atividades rurais como a criação de animais para subsistência, até que o emprego chegasse, além de práticas de lazer, como caçar no mato nos domingos. A busca por esse local foi a necessidade de empregos, pois na colônia... não tinha terra pra todos. Tu podes ver que o bairro é formado de gente de tudo quanto é lado, mas mais gente que saiu do interior, do meio rural: Ronda Alta, Soledade, Carazinho, Lagoa Vermelha... O povo vai aonde tem emprego e na época tinha bastante emprego por aqui.

A década de 70 do século passado parece ter sido um periodo de intensa migração de pequenos proprietários rurais e de outros trabalhadores campesinos, resultado do processo de êxodo rural mais exacerbado neste periodo. Percebemos que essa população migrante traz consigo uma identidade cultural semelhante, do ponto de vista da ocupação do novo espaço: eram pequenos agricultores de minifúndios, agregados que por questões sócio econômicas tiveram dificuldades em permanecer na terra. Ainda que vivendo um novo processo, o do trabalho operário, mantiveram no lugar de chegada muito dos costumes rurais (casas, hortas, vizinhos, trocas, associações paroquiais). Foram, portanto, buscar na cidade, algumas oportunidades, entre elas a de trabalho e de infra-estrutura mais adequada a fim de oferecer uma perspectiva de vida melhor para a família; sem, no entanto, abandonar costumes ligados à vida do campo. Alguns depoimentos dos moradores ilustram o que acabamos de descrever:

Nós viemos pra cá em 1973 e aqui era campo. Pra lá onde é o Valinhos, nós iamos caçar nos domingos, era tudo mato. Moramos aqui há 28 anos e viemos pra esse lugar porque a mulher pôde trabalhar na escola aqui perto e eu na COPASSO (Cooperativa de grãos), então conseguimos um terreno aqui perto e construimos. O bairro foi crescendo daqui para a Hipica, Valinhos...

Eu trabalhava no interior de Carazinho, na lavoura, depois casei (1962) e dois anos depois vim morar em Passo Fundo porque aqui tinha mais emprego.

Moravam em Lagoa Vermelha e ali trabalhavam na lavoura. Como a escola era distante da moradia dificultando o acesso das crianças à educação formal, rerolveram adquirir uma casa (a que moram até hoje) em Passo Fundo. Com a vinda para a cidade, a vida ficou melhor, pois os pais conseguiram emprego no Estado. A mãe na Brigada Militar (de cozinheira) e o pai na EMATER. Nesse local havia dois colégios bons onde todos os filhos puderam estudar. A Sandra fez as primeiras séries em colégio 
regular e depois começou a freqüentar a APAE até uns quatro cinco anos atrás.

Outro fator que fazia da região um atraente pólo migratório era a proximidade com a estação de trem. Na época, o acesso ao município faziase, exclusivamente, de trem: viagem, transporte de produção, etc.

Aqui tinha os trilhos que movimentavam muito. Quando nós precisávamos viajar era de trem, tudo vinha de trem. Agora é que o trem só transporta petróleo, antes era de tudo.

Mas, se antes o trem era sinônimo de prosperidade, agora as imediações da via férrea denotam miséria, sub habitação, violência. Nas proximidades da linha do trem, que atravessa o bairro, localiza-se a região (pertencente a RFFSA) conhecida como "beira-trilho". É uma área "invadida", ou seja, não regularizada pela prefeitura por ser local proibido para residência, conseqüentemente, sem infra-estrutura que permita condições minimas de habitação:

Tem até a população beira-trilho. Aqui pra nós só pertence duas quadras, mas têm umas dez quadras de casas construídas na beira dos trilhos... que foi invadida pelos moradores que foram chegando aqui e não tinham onde morar.

Como vem ocorrendo em proporções cada vez maiores no Brasil das últimas décadas, reflexo do processo de urbanização acelerada, essa situação está sendo avaliada pela justiça e é manchete constante nos meios de comunicação local.

Essa população parece ficar à "beira" também no imaginário dos moradores mais antigos que, talvez, preferissem não contar com esse cenário no "seu" bairro.

Se tu ouvir falar que aconteceu alguma coisa ruim no bairro, pode saber que é da Grande Vera Cruz, mas não da nossa Vera Cruz. Tudo o que tem de ruim: roubo, briga, gostam de dizer que é daqui, mas não é daqui, é dos arredores.

Os moradores mais antigos trazem consigo um sentimento de pertença muito forte e, também, de preservação de um "lugar saudável": o 
melhor lugar pra se viver; pelo menos no que se refere ao espaço mais central do Vera Cruz, primeiro povoado da região. Procuram se diferenciar dos que foram chegando nos últimos tempos, formando os vilarejos nos arredores. Embora haja uma delimitação dos bairros pela Prefeitura Municipal, indicando a região que forma a Grande Vera Cruz, é difícil segmentá-los dessa maneira, tendo em vista que essa redefinição é relativamente recente e parece ser mais usada para marcar uma espécie de cronologia em relação à chegada ao local, ou seja, os do Vera Cruz chegaram primeiro, só mais tarde, chegaram os dos vilarejos em seu entorno.

Os novos tempos vão exigindo a criação de outras formas de lidar com o cotidiano. Os cenários de violência aparecem, normalmente, relacionados ao crescimento das áreas mais pobres da cidade, mas, além disso e, por isso mesmo, associados a uma questão de época:

Antes a gente não precisava se preocupar em deixar uma roupa no varal, em trancar a casa. Agora, até andar na rua tá um perigo!

Na principal avenida está concentrada a maior parte do comércio local. O cenário do bairro é dominado por residências, distribuídas ao longo de ruas pavimentadas e razoavelmente largas. Predominam as construções mais antigas de madeira, ou mistas (madeira e alvenaria) que guardam traços de tempos passados, reproduzindo de certa forma, as casas rurais com seus porões e quintais e, representando a possibilidade de reproduzir ou de trazer junto um "pedaço do campo".

Hoje, no espaço dos quintais, casas menores foram construídas e ocupadas pelos filhos da primeira geração de migrantes. Essa característica denota, por um lado, o fato de muitos moradores não estarem conseguindo fazer novos investimentos em habitação, permanecendo no espaço que inicialmente era ocupado por apenas uma família; por outro, a localização das casas nos dá uma pista importante para compreendermos a manutenção da constelação familiar na constituição do local. Parece haver uma necessidade de manutenção da proximidade da família, uma vez que 
os pais migraram deixando para trás os seus antepassados. Tal proximidade está calcada em um universo cultural que tem a familia como alicerce fundamental.

Maciel (2001) ao estudar a construção dos espaços femininos no bairro São José na mesma cidade, reforça que esta necessidade de manutenção da constelação familiar revela a manutenção de um ethos camponês - ainda que reatualizadas pelo meio urbano -, que privilegia a moradia próxima, na mesma propriedade, quando o tamanho da mesma o permite. Ao mesmo tempo, ao fazerem essa agregação é possivel aos seus membros certa melhora no orçamento do grupo, objetivando também a melhoria das condições de vida da família, já que essa pode ser pensada "como uma unidade da força de trabalho e de consumo centrada no casal e nos filhos, aos quais se podem agregar outros membros; porém, a sua unidade é essencial para a sobrevivência e a manutenção grupo" (MACIEL, 2001, 21). Além disso, essa característica na constituição familiar, agrega outros valores fundamentais como a relação de troca e a solidariedade.

$\mathrm{Na}$ realidade estudada, também percebemos que os familiares mais velhos colaboram, sobremaneira, com o cuidado dos filhos, com a realização das atividades domésticas e com o cuidado da propriedade (manutenção de horta, vigilância da casa). Já os mais novos, colaboram mais com o trabalho realizado fora de casa, cuidando de trazer o provento para a sobrevivência da família. Além disso, cuidam da saúde dos mais velhos. Quando é um dos filhos que apresenta um problema de saúde - a exemplo de nossos protagonistas - há uma certa "proteção" por parte da familia ampliada ${ }^{34}$, uma espécie de acompanhamento diário das atitudes e comportamentos do familiar, mas também, percebe-se a expectativa frustrada dos pais em relação ao filho(a) que tornou-se um "filho-outro" nos termos de Scali Jr. (2003), quando deveria ter conquistado maior autonomia diante da vida.

\footnotetext{
${ }^{34}$ Aqui família ampliada está significando os membros da familia que moram no mesmo terreno e que acabam por formar uma sólida rede familiar (pai, mãe, filhos, genro, nora, netos, avó, avô).
} 
A memória da vida rural faz-se presente, mesmo nos reduzidos terrenos. Pequenos espaços dos quintais são preservados para uma pequena horta ou "canteirinhos" de verduras e árvores frutíferas. Os instrumentos de capina fazem parte das ferramentas indispensáveis à lida da casa e são instrumentos que, além de manter os moradores ligados à terra, oferecem, como eles mesmos dizem, uma terapia.

Os espaços públicos e a vida social também guardam particularidades que, aos poucos, vão sendo reveladas. Pequenas e raras praças em estado de conservação precário servem mais de espaço de passagem do que de sociabilidade. É nos clubes, Centro de Tradições Gaúchas, salões de festas (religiosos), salão comunitário que os relacionamentos grupais e o sentimento local são reforçados para manter e preservar as identidades dos que ali se reúnem.

Nós sempre participamos da vida aqui do bairro. Tem o salão da
igreja, o CTG (Centro de Tradições Gaúchas) e agora tem a
associação dos aposentados que eu gosto de jogar bocha. Tem
outros jogos também. A mulher joga dominó, mas tem mais. A
gente se envolve bastante... Venha comer um galeto com massa conosco (no salão da paróquia), a gente é pobre, mas se diverte!

Escolhas por diferentes lugares indicam o tipo de ocupação social. $O$ CTG, por exemplo, é um espaço dos que cultivam as tradições gaúchas: danças, músicas, culinária, chimarrão, cavalgadas aberto para os de fora do bairro. Seus bailes, cursos ou invernadas congregam um número maior de pessoas de diferentes idades e de um público já iniciado nas tradições regionais: os do pedaço do tradicionalismo gaúcho.

No dia-a-dia, a rua e o quintal das casas são os espaços de maior sociabilidade. Durante o dia, a rua é lugar de conversas rápidas, particularmente de um público feminino que faz a lida da casa ou vai às compras. À tarde, o cenário se dinamiza, abrindo espaço para outros usos da rua. É o retomo do trabalho, o horário do lazer, de fazer uma visita ao vizinho - freqüentemente lembrado como o parente mais próximo -, de ida ou de volta à/da escola. 
Alguns fragmentos de meu diário de campo, ilustram a dinâmica das relações nos espaços do bairro:

É final de tarde de verão e me dei conta de que o movimento das ruas e dos pátios das casas é bem mais intenso do que nos outros horários do dia. Os ares mudam por aqui. De cenário de passagem, a rua dá lugar a práticas de sociabilidade. É hora do chimarrão em casa, com os integrantes da família ou com algum vizinho ou conhecido. Enquanto os adultos conversam, as crianças e adolescentes caminham e até batem uma bola com a vizinhança. As trocas parecem ser mais evidentes. Enquanto caminho, me acenam pessoas conhecidas. Ao anoitecer, todos vão se recolhendo e o espaço da rua fica praticamente vazio.

A memória dos adultos também registra com saudades as atividades lúdicas da época em que eram adolescentes. No final da tarde a gente gostava de jogar uma bola, começava em dois e de repente enchia a rua,...

De passagem, pude observar à distância quanta gente visitava dona Giúlia que estava doente. Um cenário típico do horário (final da tarde) e da situação (ter alguém "adoentado" em casa). Pude observar Pomba-Rola na "roda", atenta à conversa. Como um costume bem gaúcho, o chimarrão também circulava para garantir, simbolicamente, o bom acolhimento dos visitantes e sua inclusão no grupo.

Dona Bernardina sintetiza esse convivio: o que tem de bom aqui é a vizinhança. É uma irmandade. Tem muita gente boa que me dá a mão... A minha casa é sempre cheia. Eu me dou com todos: é preto, é branco, é pobre, é rico, nada me importa!

Num domingo, durante o dia, novos cenários: vi movimento no campo de futebol atrás do centro comunitário, onde dois times jogavam, animados por uma torcida relativamente grande. Num bar, as pessoas conversavam, ouviam música e bebiam.

Em uma praça, defronte à igreja católica, outros conversam, atualizam as noticias da comunidade (quem adoeceu, quem melhorou, quem casou). Nesse dia, havia a expectativa da chegada do novo padre, fato que estava despertando curiosidade entre as pessoas.

Outro aspecto a ser destacado refere-se às práticas religiosas. Basta dar uma caminhada pelas ruas para visualizar o grande número de igrejas e outros espaços de cultos religiosos: centros de umbanda, casas espírita (mais lembradas pelos moradores, do que visiveis na paisagem). Estas últimas parecem ser mais novas no bairro, se comparadas à igreja católica. Todas essas práticas religiosas guardam forte valor simbólico e acabam por mediar diferentes aspectos da vida dos moradores, em especial, a questão 
da saúde e da doença. É o que se percebe pelos relatos de nossos depoentes:

(A saúde), eu acho que tem a ver com a nossa fé. Às vezes nós fraquejamos na nossa caminhada. A gente erra em alguma coisa. É a lei da natureza, ela está nos cobrando, então é uma conseqüência. Tem um Ser Superior que deixa a gente sofrer pra ver até onde a gente vai. Às vezes que eu reajo é porque eu sinto a presença de Deus, eu não estou sozinha.

Ajuda... só dos hospitais, dos médicos e Daquele lá de cima... Pra mim tem Deus, eu rezo muito, Nesse eu acredito.

O padre vem aqui uma a duas vezes por mês. Eu sou católica e sempre que podia ia à missa. Agora que não posso mais, então, o padre vem aqui me dar à benção e a comunhão.

As pessoas não te contam, mas a maioria vai nesses centros (umbanda, espirita) quando tem algum problema de saúde. Isso ai tem crescido cada vez mais por aqui, embora a gente não veja muito, porque de dia é casa normal e de noite vira centro (a moradora me mostra duas casas na rua, onde se desenvolvem práticas religiosas, à noite).

Sob o olhar das crianças, o Hospital Psiquiátrico Bezerra de Menezes, localizado em uma das extremidades da "Grande Vera Cruz", e seus pacientes, ganham outros significados: no faz-de-conta os pacientes de doentes podem virar heróis e, de perigosos, podem surgir como amigos. São as crianças, seus vizinhos mais próximos que moram na "beira-trilho" e que circulam pelas proximidades, cuidando dos carros para ganhar uns trocados que me dizem como é morar perto do hospital. Sintetizam em poucas palavras como percebem seus "vizinhos" e o lugar que os "acolhe" temporariamente:

O menino de sete anos disse-me que gostava de morar perto do hospital: é bom, eles são doentes, são nossos amigos,... eles chegam aqui de ambulância, com a polícia... Outra criança, como se tivesse narrando uma história infantil falou: outro dia um fugiu correndo...

São três cenas que se acostumaram a ver: a primeira é o "espetáculo" da chegada; depois, o convivio próximo com os internos no pátio do hospital e ai eles se comunicam, sem medo, com "os amigos doentes", e a outra cena, é o "espetáculo" da fuga que, no imaginário infantil, parece ter um sentido lúdico.

As condições disciplinares de chegada ao hospital parecem simbolizar a necessidade que a sociedade tem de retirar os sujeitos "desviantes" do convivio; de controlar e normalizar os espaços sociais; de ter espaços para tratar a sua intolerância sob o pretexto do "cuidado". Mas, parecem também simbolizar, 
segundo Certeau (2002), a antidisciplina dos internos que expressa uma forma de não se conformar totalmente com esse lugar, mesmo que seja de uma forma "caricata", através da fuga, que tem o sentido de liberdade, ou ainda, da possibilidade de circulação, de conversação, de pequenas trocas com os "amigos" - vizinhos que podem trocar um pequeno agrado, uma palavra, contar-lhes um pouco das crianças de suas vidas (filhos, irmãos, netos, sobrinhos) até como forma de sublimar a saudade.

O bairro, que num primeiro momento se apresenta como um espaço indiferenciado e homogêneo, vai assumindo, no decorrer da pesquisa, várias feições. As circunstâncias que envolveram a sua ocupação foram marcadas pelo "desafio" de construir um espaço para as famílias, resultante, sobretudo, de um processo de migração rural-urbano que ocorria em todo o Estado. Se esse processo trouxe rupturas de laços com os que ficaram, o modo como a vida se organizou no bairro fez com que se constituíssem novas relações, de tal maneira a reproduzir, reatualizar e recriar processos sociais dos lugares de origem. A atualidade conformou um outro cenário mediado por alterações geradoras de necessidades e contradições novas, tecendo uma dinâmica de ruptura e conservação, uma diversidade que se articula e forma a cultura local.

Nesse sentido, a dinâmica do bairro constitui-se em exercício de preservação do modo de vida de suas cidades de origem e, ao mesmo tempo, um constante adaptar-se a novas formas de viver, nem sempre as que, no imaginário dos moradores, os impulsionaram a sair de seus locais de origem. O que esperavam - emprego, mais conforto, acesso à educação formal, etc, - tornaram-se aqui, expectativas nem sempre alcançadas pelo desordenado processo de urbanização e crescimento da cidade. O convívio mais comunitário cedeu lugar a uma população nômade, impessoal e exposta às mazelas da vida citadina: violência, insegurança no interior da própria casa, aumento do trabalho feminino informal, dificuldade de aquisição de novos imóveis para os filhos, sobrecarregando as pequenas habitações.

A permanência e a estabilidade no bairro caracterizam o modo de vida dos primeiros migrantes, fazendo um contraponto com o momento atual 
do nomadismo dos novos moradores que vivem ali na condição de inquilinos. Esta condição os impede de estabelecer relações mais duradouras com a vizinhança mais antiga que, por sua vez, faz questão de manter uma certa distância em relação aos que chegaram por último. Isto parece indicar que a fixação tem um forte sentido de enraizamento, de prosperidade. As familias precisam se auto-referenciarem, precisam manter valores como família e proximidade com a vizinhança. É esta tensão constante entre o rigido e o flexivel de Certeau (1995) que as faz resistir aos problemas decorrentes do processo migratório e às mudanças do mundo contemporâneo.

Nas palavras do autor:

Sob esses aspectos conjunturais, a cultura oscila mais
essencialmente entre duas formas, das quais uma sempre faz
com que se esqueça da outra. De um lado ela é aquilo que
"permanece"; de outro, aquilo que se inventa. Há, por um lado, as
lentidões, as latências, os atrasos que se acumulam na
espessura das mentalidades, certezas e ritualizações sociais, via
opaca, inflexivel, dissimulada nos gestos cotidianos, ao mesmo
tempo os mais atuais e milenares. Por outro, as irrupções, os
desvios, todas essas margens de uma inventividade de onde as
gerações futuras extrairão a 'cultura erudita' (CERTEAU, 1995,
p.239).

Assim o bairro não é apenas uma superfície urbana, é também uma realidade "fabricada" no sentido proposto por Certeau (1995), espessa de sentidos para os seus moradores que fazem dele usos distintos através de um sem-número de trajetórias que compõem um lugar. Para que assim seja percebido, toma-se necessário afastar a idéia de aparente simplicidade ou homogeneidade que pode mascarar relações complexas presentes neste espaço. Em outras palavras, faz-se necessário buscar a compreensão dos códigos que compõem, sobrepõem e/ou entram em conflito, constituindo assim, percursos que podem ser considerados como um "guia cinco estrelas" ${ }^{\prime 35}$ em termos de possibilidade de expressão e de conexão com a realidade social.

${ }^{35}$ Expressão utilizada pelos Acompanhantes Terapêuticos de $A$ casa - São Paulo, em alusão aos itinerários construídos pelos seus acompanhados na rua. 
Ainda que entendamos o campo de pesquisa para além de um espaço concreto como o bairro, percebemos inicialmente a necessidade de estabelecermos nossas referências a partir dele. Nesse sentido, o bairro foi meu ponto de partida, meu recorte inicial, através do qual pude identificar os "fora", "os doídos", os "que não batem bem", na concepção dos moradores. O bairro, no sentido concreto, se assim podemos chamá-lo, possibilitou-me construir o contexto sócio-histórico-cultural do grupo que ali habita. A partir de então e, identificadas as pessoas, passei a acompanhar suas relações, interações, circulação pela cidade, instituições, enfim, suas trajetórias ${ }^{36}$. Vale dizer que a constituição de nosso recorte de pesquisa deu-se no processo do trabalho de campo quando, a partir dos nossos atores, íamos apreendendo o que chamamos de um modo especifico de "lidar" com essa condição de vida.

${ }^{36}$ Adiante detalharei como está sendo compreendida e empregado as "trajetórias" nesse trabalho. 


\section{Imagens do bairro fotografadas durante a pesquisa}

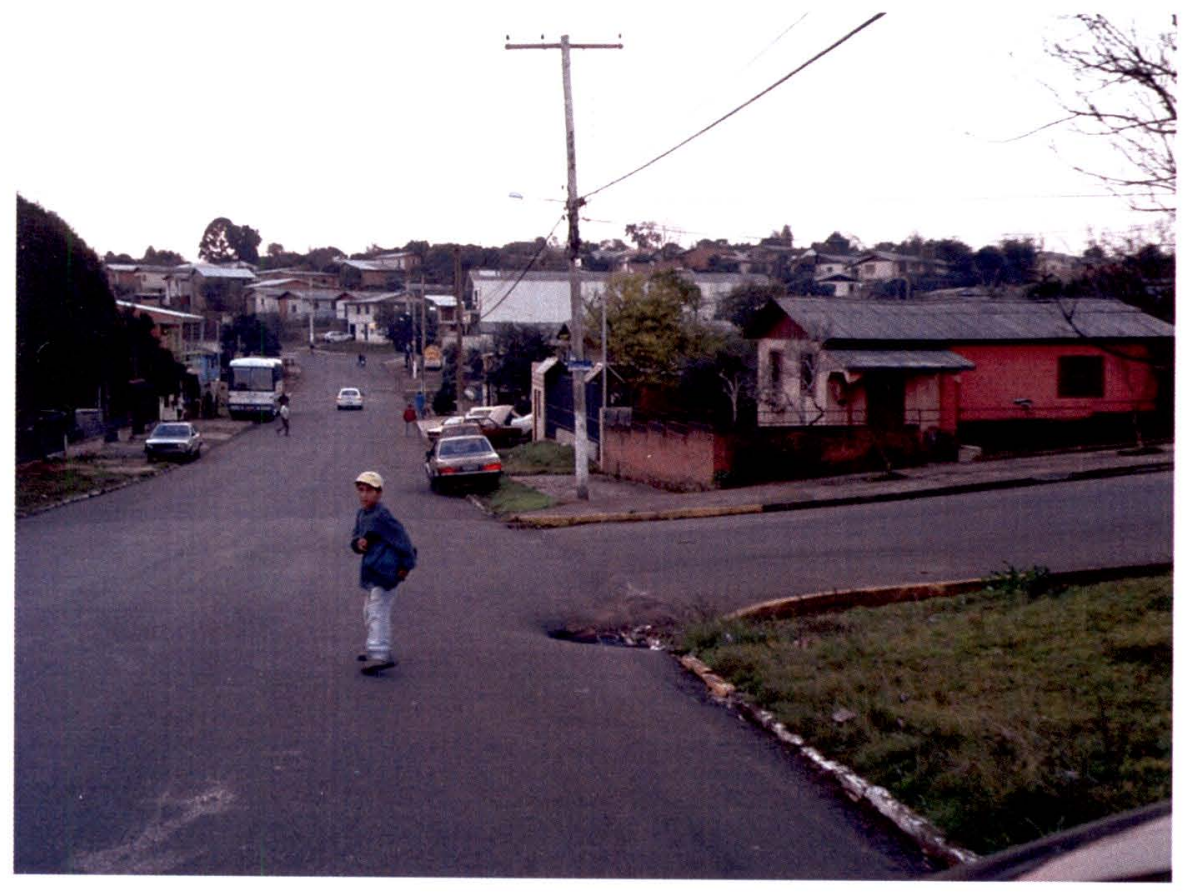

Foto de Bernadete M. Dalmolin, 2004. Vista parcial da rua São Sebastião. Bairro Vera Cruz, Passo Fundo/RS

Foto de Bernadete M. Dalmolin, 2004. Vista parcial da rua Santana Bairro Vera Cruz, Passo Fundo/RS.

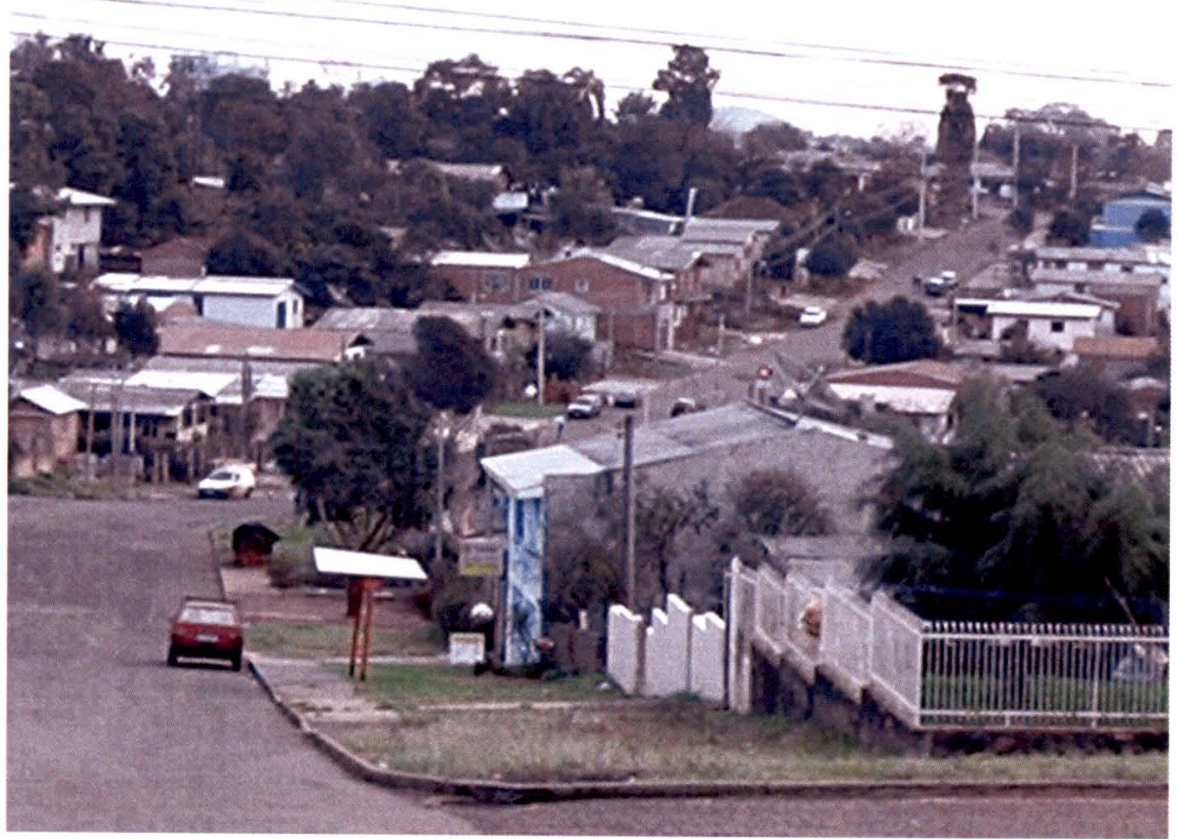




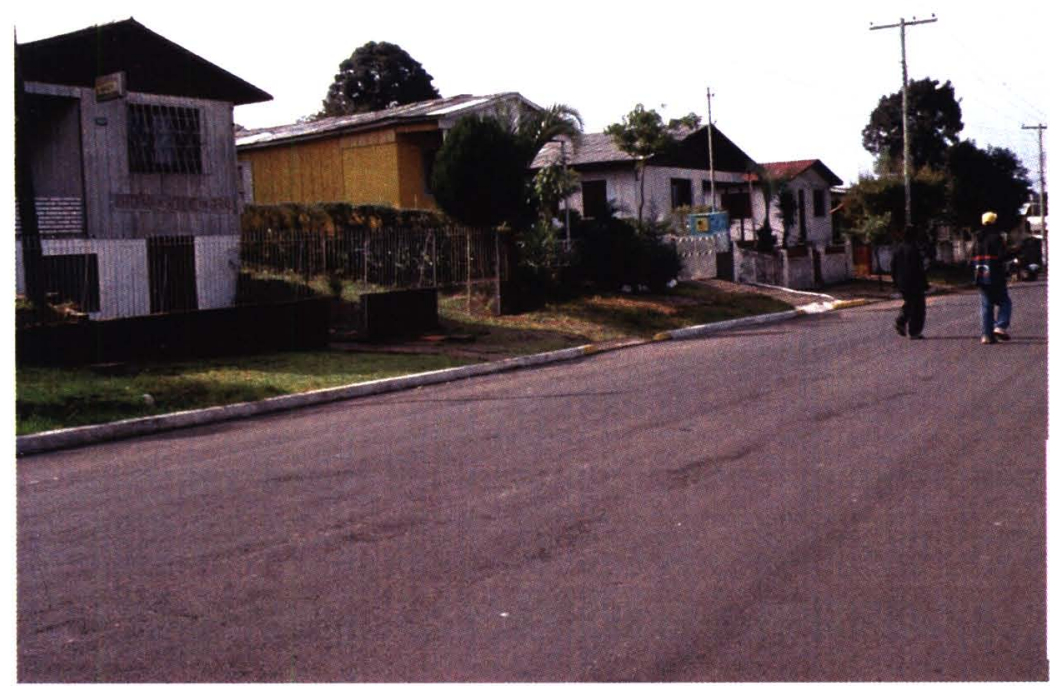

Foto de Bernadete $M$. Dalmolin, 2004.

Construções típicas do bairro Vera Cruz, Passo Fundo/RS.

Foto de Bernadete $M$. Dalmolin, 2004. Crianças jogando bola no final da tarde. Rua Uruguaiana Bairro Vera Cruz, Passo Fundo/RS.

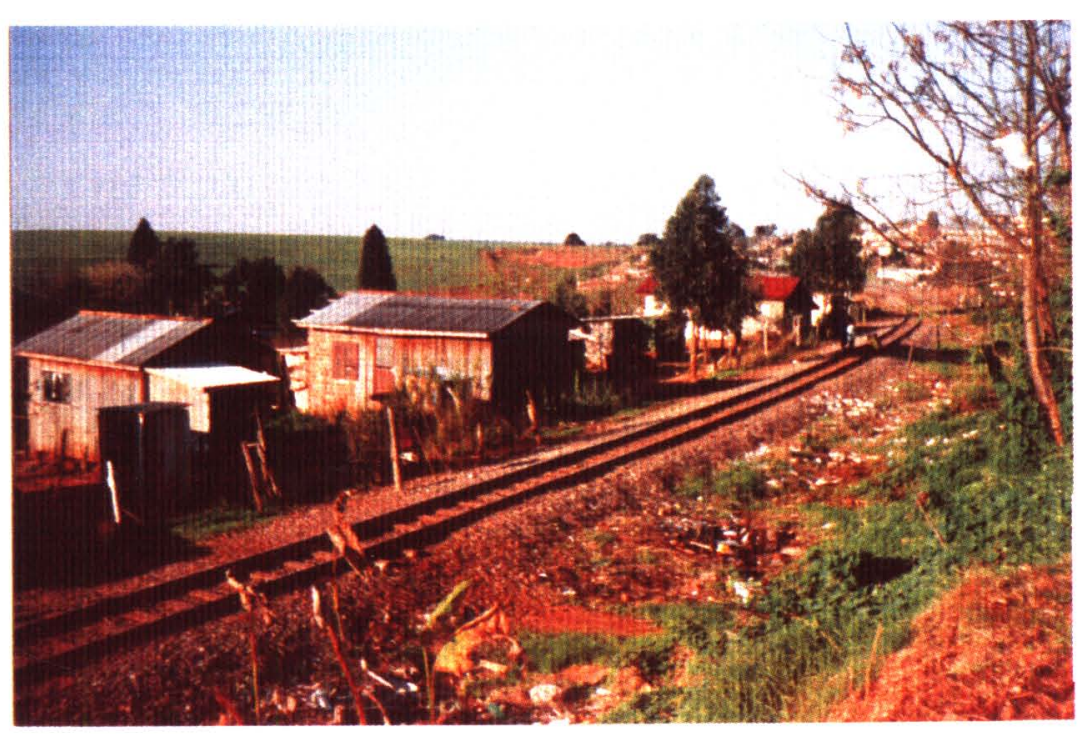

Foto de Bernadete $M$. Dalmolin, 2004. "Beiratrilho" - Grande Vera Cruz, Passo Fundo, RS. 


\subsection{A trilha seguida na construção da pesquisa}

O movimento por caminhos sinuosos da pesquisa foi decorrente da relação que foi se estabelecendo entre pesquisados e pesquisadora. Tratouse de um exercício relacional, pois para apreender os modos de vida do outro tive de trabalhar minha própria disponibilidade interna, tive de desfazer-me o quanto possível dos pré-conceitos em relação ao que me era estranho, enfim, tive de olhar o outro ao mesmo tempo em que me olhava. Nesse processo, o campo de pesquisa foi se constituindo: a fase inicial mais "engessada", linear, fruto de um distanciamento ou de relações que estavam por se estabelecer foi, lentamente, dando espaço ao desvelamento de outros planos. Por isso, compartilho a idéia de campo de pesquisa de Peter Spink (2003, p.11) que o entende como algo além do espaço "físico" onde o tema pode ser visto (este é uma das partes do campo), é o campo-tema, ou seja, "são as redes intersubjetivas que se interconectam em vozes, lugares e momentos diferentes, que não são necessariamente conhecidos uns dos outros".

Assim, esse processo também não poderia estar distanciado de minha biografia, da necessidade de "enquadramentos" do campo de pesquisa provenientes de uma determinada racionalidade. Se fui tomada durante um periodo por uma inércia objetiva, não faltaram motivações mais profundas, desejos e uma trajetória pessoal não conformada com esse jeito de "fazer ciência/saúde" somados à caminhada que o doutorado propiciou: aulas, supervisões, leituras, trocas e reflexões. Com o entendimento de que este é um processo que envolve diretamente o pesquisador, modificando-o, flagrando-o, construindo-o juntamente com o objeto de estudo, destacarei também diferentes aspectos/momentos desse encontro intersubjetivo.

Segundo Peirano (1992), em antropologia não há como ensinar a fazer pesquisa como se ensina em outras abordagens metodológicas, pois a pesquisa está diretamente relacionada à biografia do pesquisador, ao objeto de pesquisa, ao enfoque teórico ou de que lugar pretendemos abordá-lo, do contexto histórico mais amplo, das relações que se estabelecem entre 
pesquisador e o campo de pesquisa, além dos imprevistos que fazem parte do pesquisar. Pois bem, vivenciei este processo duplamente: primeiro, com a insegurança de quem está "de fora", na condição de iniciante, aprendendo a olhar os sofredores psíquicos através dos recursos metodológicos que a etnografia nos oferece e, segundo, manifestando a intenção de fazer ao leitor, que também é "de fora", um convite para que nos acompanhe mais "de perto" nesta travessia.

Ao iniciar a pesquisa, meu contato com o bairro limitava-se às visitas domiciliares realizadas a alguns sujeitos em sofrimento psíquico e desenvolvidas junto à disciplina de Enfermagem em Saúde Mental. Busquei informações importantes para o reconhecimento e aproximação dos sujeitos. Através de levantamento no Sistema de Informação Hospitalar/SUS e de um relatório acadêmico ${ }^{37}$, identifiquei as pessoas do bairro que haviam sido internadas em hospital psiquiátrico, do municipio ou fora dele, no ano de 2001 (endereços, sexo, idade e diagnósticos médicos). Fiz o mesmo com as cadastradas no Caps da Prefeitura Municipal de Passo Fundo. Parti então, para o local com um mapeamento - o "quadro oficial das instituições de saúde" - que me permitiu uma primeira aproximação com os sofredores psíquicos.

Não tinha a preocupação de identificar in loco todas as pessoas que haviam passado por instituições psiquiátricas, mas, pretendia, de posse desse conjunto de informações, entender o sistema classificatório da população local, ou seja, queria saber, quais eram as categorias locais de "pessoas em sofrimento psíquico" e em que medida elas se aproximavam da

\footnotetext{
${ }^{37}$ Material extraido do documento: "Mapeamento e cadastramento dos egressos do Hospital Psiquiátrico Bezerra de Menezes na área de abrangência do ambulatório Pedro Ávila" (a área de abrangência é a Grande Vera Cruz). Foi desenvolvido através de um trabalho da disciplina de Saúde Pública II do curso de enfermagem da UPF, coordenado pela professora Lúcia Maria Mottin que trabalhou o "problema" Dificuldade para o acompanhamento dos egressos do HPBM, na área de abrangéncia do Ambulatório Pedro Ávila. Era uma demanda da disciplina de Saúde Mental. Essas informações foram obtidas através do "sistema de contra-referência" do Hospital para a Secretaria Municipal que tinha por objetivo mapear as pessoas com "transtornos mentais" mais graves da região da Grande Vera Cruz (que necessitaram internação psiquiátrica e que freqüentam o serviço de atenção diária - CAPS).
} 
classificação oficial (entendendo que essas categorias são conceitos construídos nessa interação).

Nessa etapa, tomei como referência as observações mais gerais sobre a dinâmica do bairro e das pessoas, conversas informais, visitas, relatos com o propósito não de buscar o inusitado, mas o "reiterativo, o padrão, a norma" (MAGNANI, 2000, p.37). Num primeiro momento, as caminhadas deram-se em trechos mais familiares, em ruas de maior concentração de pessoas e também de maior concentração de internados no mapa oficial, de forma relativamente aleatória. A partir desse contato, e aos poucos, fui me aproximando, procurando construir relações que mais tarde dariam sentido à investigação. Destaco aqui, alguns registros dessa aproximação:

Andei no bairro durante algum tempo. Circulei e fui observando a rotina das pessoas. Fui até o Ambulatório Pedro Ávila para contatar a enfermeira, única pessoa conhecida trabalhando neste local e com quem tenho laços profissionais/afetivos. Minha intenção era obter através dela algumas informações e identificar informantes. Assim, consegui contato com alguém que conhecia bem o bairro, marcamos uma conversa na casa dele.

Na conversa com seu Ângelo e dona Marisa, ouvi os primeiros comentários sobre pessoas com problemas mentais do bairro: eu me recordo só de um alcoólatra que era até meu colega... tinha um andarilho que ficava aqui por perto, agora já morreu... Eu conheço aqui na rua Taquara um deficiente físico e mental. Esse diz que ninguém pode com a vida dele... Vou te contar um outro caso, não sei se tem alguma coisa a ver com isso, mas já que tu vais conhecer o bairro... tem uma mulher aqui, muito pobre, ela já tem 10 filhos, dois morreram e está grávida de novo...

Andando por ali, observei um movimento de pessoas mais idosas que se deslocavam, entrando e saindo do salão comunitário. Soube que era o dia do trabalho das moças da Universidade com os que têm pressão alta. De imediato lembrei que as colegas da UPF mantêm o trabalho também durante as férias. Fui até lá e encontrei um grupo de pessoas que aguardavam atendimento, enquanto outras estavam sendo atendidas por uma colega professora e outros funcionários do centro de saúde. Fui calorosamente bem recebida e passei a freqüentar e observar esse espaço com certa regularidade. Enquanto esperavam a vez, as pessoas conversavam, querendo saber umas das outras. Registrei algumas conversas com a enfermeira nas quais as pessoas "justificavam" a pressão alta: também, eu tenho sofrido tanto com aquele homem... ele continua bebendo e fazendo correria... eu não tenho conseguido dormir de noite, porque os ladrões levaram o meu fogão e agora eu não tenho como fazer comida pra minha familia, pros meus netinhos... 
Minha presença contínua no salão comunitário, e o fato de saberem que eu era uma profissional da saúde mental constituiram-se em dados facilitadores para que logo fosse convidada a visitar parentes dos freqüentadores do salão que, segundo eles, apresentavam "problemas mentais". Assim, iniciei a construção de uma pequena rede de relações.

Essas primeiras conversas e observações serviram para que o bairro, o modo de vida de seus habitantes e os sistemas simbólicos que eles constroem sobre os problemas de saúde, se tornasse para mim, um pouco mais familiares. Com o mapeamento à mão, procurava identificar nas proximidades dos endereços apontados, indícios dos sujeitos com sofrimento psíquico e, se possível, também chegar até seus domicílios e conhecê-los assim como os seus familiares. Pude valer-me das informações dadas pelos moradores que ia conhecendo, dos que vinham, dos que já eram meus conhecidos, das funcionárias da Unidade de Saúde, colegas da Universidade. Com o objetivo de captar as categorias o sistema de classificação local, procurava não revelar o meu mapa, embora algumas vezes tive de torná-lo conhecido, particularmente quando não tinha nenhuma outra possibilidade de entrada através dos informantes. Mais alguns fragmentos de meu diário de campo testemunham esse processo de reconhecimento:

Resolvi ir até a uma casa que o meu mapa indicava ter dois usuários de serviços de saúde mental. Deparei-me com uma senhora, na casa de fundo de quintal e, quando perguntei por João-de-Barro veio a resposta: Mas então o João-de-Barro que tu tá procurando é o meu João-de-Barro, então entra aqui e vamos conversar. Ele agora tá dormindo. Dispus-me a conversar com a própria mãe. Enquanto conversávamos, vi uma pessoa cambaleante que identifiquei como um dos meus conhecidos das instituições de saúde mental. Quanto à Angela, outra pessoa a quem eu tinha ido procurar, soube que estava trabalhando.

Em outro momento, ao procurar Nádia, acabei encontrando dona Ivone, uma senhora, não constante do meu mapa, mas que alguns moradores já haviam citado como "doente mental". Foi muito receptiva comigo. Próximo à casa de dona Ivone encontrei mais duas pessoas que tinham estado internadas recentemente. De contato em contato aproximei-me de Lurdes, Maria, Bem-Te$\mathrm{Vi}$ e tantos outros. Na verdade, era comum que um me indicasse outro. O fato de eles me "apresentarem", de certa forma, me deixava mais a vontade, era uma espécie de passaporte. Esse momento sinalizava que a classificação deles em relação às categorias, diferenciava-se do mapa que eu portava. Isso ficou ainda mais evidente no encaminhamento que alguém me fez ao 
vizinho e no comentário sobre uma "cartinha" (correspondência padrão encaminhada a todos os egressos do hospital psiquiátrico) que recebera do Caps. Pra mim, que sofro de depressão ser convidada pra ir lá foi uma ofensa, porque eu já cuidei de um doente mental que freqüenta lá, um parente[...]. Ele até com a mão comia...

O cotidiano do bairro foi assim ganhando força e dinamicidade na investigação. Nesta primeira etapa da pesquisa, meu objetivo era o de entender minimamente o bairro: quem eram seus moradores; quem era para o nativo a pessoa em sofrimento psíquico; fazer uma aproximação com eles e seus familiares; entender o "comportamento" mais geral desses sujeitos diante da situação vivida. Cruzando essas informações, fui formando minha rede de observação e de informantes. Etapa longa e trabalhosa que só interrompi ao perceber uma espécie de saturação ou recorrência no conjunto das informações, algumas regularidades ${ }^{38}$.

À medida que fui me tomando mais próxima, as categorias locais foram se firmando e o mapa oficial das instituições foi sendo reordenado, permitindo um primeiro recorte, através do qual pude perceber como os moradores do Vera Cruz definem o sujeito estudado. Nessa fase da pesquisa também foi possivel uma identificação de relações mais objetivas com as instituições que oferecem tratamento, mais especificamente o circuito ligado à atenção à saúde mental, dando-me uma base geral sobre uma das práticas mais visíveis no campo.

Este circuito, entendido como um conjunto de instituições e práticas que envolvem a busca da atenção à saúde do sujeito em sofrimento psíquico, é constituído de: serviços de saúde geral (pronto atendimento, hospitais gerais, farmácia pública), serviços de saúde mental (hospitais psiquiátricos e Caps) além de outros "apoiadores" institucionais (promotoria e defensoria pública) que ganham visibilidade nessa rede de proteção aos

\footnotetext{
${ }^{38}$ Regularidades, que não "[...] se apresentam sob a forma de uma sucessão de elementos sem nexo, produto de iniciativas erráticas e atomizadas", mas situam os espaços de vida das pessoas em sofrimento psíquico, oferecendo elementos fundamentais para análise e novos aprofundamentos, diferenciando-o de olhares de longe e de fora, feitos em situaçōes isoladas, que, conforme o mesmo autor, provocam a sensação de anonimato, fragmentação e desordem (MAGNANI, 1999, p.57-69).
} 
direitos dessas pessoas. Os arranjos construídos nesse circuito serão compreendidos de melhor forma, no entrelaçamento com o momento seguinte da pesquisa, quando forem analisados no capitulo cinco.

$\mathrm{Na}$ etapa seguinte, e tendo como subsidio o trabalho realizado no primeiro momento, aprofundei o estudo dos trajetos de cinco sujeitos identificados no local como pessoas que vivem a experiência do sofrimento psíquico grave. Nesse momento da pesquisa, os espaços de observação e diálogo respeitavam, em parte, os fluxos das relações que se estabeleciam no cotidiano desses sujeitos - meus protagonistas -, o que me fez aumentar a velocidade e a diversidade dos espaços e práticas buscando os sentidos que compunham cada trajeto.

Assim podemos dizer com as palavras de Duarte que a pesquisa

[...] transcorreu sob a égide de uma opção: a de auscultar o quotidiano, a de acompanhar longamente a prática de muitos desses sujeitos, perdendo certamente dimensões cruciais de sua vivência, mas ganhando, estou certo, em abrangência e acendendo a um plano de habitus que poderia ser obscurecido pela excessiva sistematização sempre depreensivel de todo e cada um dos códigos religiosos ou - sobretudo - dos códigos médico-psiquiatricos (1986, p.16).

A busca de sentido no cotidiano é compreendido na perspectiva de Spink e Medrado (2000, p.41) que o definem como "uma construção social, um empreendimento coletivo, mais precisamente interativo, por meio do qual as pessoas - na dinâmica das relações sociais historicamente datadas e culturalmente localizadas - constroem os termos a partir dos quais compreendem e lidam com situações e fenômenos a sua volta".

Ao definir os protagonistas, passei a acompanhá-los, observá-los nas relações cotidianas buscando novas informações exigidas no transcurso da pesquisa. Por exemplo, Beija-Flor quando não estava internado, passava o dia na rua. Pude identificar com quem ele se relacionava naquele espaço, o que buscava, de que estratégias lançava mão. João-de-Barro tinha uma relação muito intensa com instituições de saúde, busquei compreender o que se destacava nelas. Bem-Te-Vi passava o dia todo no Caps, mas a 
possibilidade de desenvolver atividades na rua também o vitalizava. Assim fui construindo as trajetórias. Nesse período também "perdi" alguns sujeitos pela mudança de endereço. Apesar disso, permaneceram presentes através da memória dos moradores, a Ivone, seu irmão, que não cheguei a conhecer pessoalmente e o Iradi.

A análise do material foi se dando progressivamente, como resultado da articulação oferecida pelo universo da pesquisa, das minhas reflexões no momento em que me defrontava com ele ancorada no referencial teórico. Neste trabalho tive a preocupação de "[...] descobrir formas diversas de subjetivação da vida social, construídas na história diferenciada dos (nossos) protagonistas e cujo estudo nos leva a construções sobre processos de subjetivação social sobre os quais não tínhamos a menor idéia antes de começar a pesquisa" (GONZÁLEZ REY, 2002, p.154).

Para a sistematização do material procurei articular o conjunto das informações nos diferentes momentos do trabalho de campo, ou seja, a sistematização foi acontecendo na medida que as informações do universo da pesquisa foram se somando, não tendo momentos distintos entre o levantamento das informações e as interpretações, seguindo a orientação de análise para abordagens etnográficas (MAGNANI, 1999; VICTORA et al. 2000).

Fui relendo, organizando e selecionando os "dados brutos" contidos nos diários de campo em relatórios provisórios, a partir dos quais, tornava-se possivel refinar as análises e fazer novas buscas para a melhor compreensão do objeto. Esses momentos de sintese dos dados foram indicando os caminhos seguintes, que mantinham como unidade de análise as relações e práticas sócio-afetivas-culturais que constituiam as experiências cotidianas das pessoas em sofrimento psíquico.

Ordenei o material de tal modo a destacar nessas experiências, os empreendimentos mais relevantes que compõem as interações dos sujeitos, buscando captar e organizar características significativas que possibilitaram 
compreender e aprofundar aspectos das trajetórias singulares, marcadas por situações antagônicas, pactos e resistências vividas nas relações cotidianas em diferentes espaços da cidade. Sabemos que ao caminhar para uma determinada direção o pesquisador faz escolhas que acabam por excluir muitos dos aspectos relacionados ao tema, o que não significa, necessariamente, que sejam irrelevantes, mas apenas que o trabalho tem um limite.

Como ressalta Duarte (1986, p.17), o sentido no processo da pesquisa que cala profundamente o pesquisador vai além do método e das técnicas escolhidas, no fundo, o sentido vem quando toca sua alma: "Em primeiro lugar porque o rompeu a presença do pesquisador, que fez vir à sala a dona da casa, que fez interromper a sesta do marido, que fez com que se trouxesse o café na bandeja de plástico e que se calassem as crianças". 


\title{
CAPÍTULO III - O SOFRIMENTO PSÍQUICO E SUAS MÚLTIPLAS FACETAS
}

\author{
Estive doente \\ dos olhos \\ da boca \\ dos nervos até \\ destes olhos que viram mulheres perfeitas \\ da boca que recitou poemas em brasa \\ ah... dos nervos manchados de fumo e café \\ Estive doente \\ não quero escrever \\ Eu quero um punhado de estrelas maduras \\ Eu quero a doçura do verbo viver. \\ Poema de autor desconhecido. \\ Encontrado em hospital psiquiátrico do Estado de Pernambuco.
}

(CAMARGO, 1991, p.51)

Atualmente coexistem, tanto na literatura especializada quanto no cotidiano dos serviços de saúde mental, duas grandes concepções reconhecidas neste campo denominado como "psi": a psiquiátrica ou orgânica e a psicológica. O conjunto de serviços e práticas que foram se constituindo para equacionar a problemática da saúde mental na cidade, apresentado no primeiro capitulo, é originário, principalmente, da concepção psiquiátrica que se consolidou ao longo da história como o modelo científico para o estudo dos processos psíquicos, e continua ganhando força na atualidade.

Vale dizer que muitas outras disciplinas também foram, ao longo do tempo, contribuindo para ampliar o olhar sobre essa condição de vida. Neste capítulo, tratarei alguns aspectos das concepções psiquiátrica e psicológica sobre o sofrimento psíquico, além da contribuição da antropologia de que também nos valemos. Minha intenção não é a explicitação de conceitos, mas sim estabelecer um diálogo com determinadas concepções teóricas relativas a esta condição humana, sobretudo as que predominam na atualidade, discutindo a repercussão de suas práticas no cotidiano das pessoas que vivem o sofrimento psíquico. Sem a pretensão de abranger as inúmeras abordagens decorrentes desses referenciais $\mathrm{e}$, reconhecendo que 
nenhuma delas, isoladamente, abarca essa realidade, assumimos que estamos diante de um "problema complexo" no dizer de Morin.

É oportuno registrar que existe uma difusão de estudos ${ }^{39}$ sobre a loucura e suas trajetórias históricas que não serão retomados aqui. Diferentes formas de compreensão da loucura podem ser resgatadas na história desde a Antigüidade quando ainda não se falava nela enquanto objeto da medicina, da psiquiatria. Dessas formas, algumas permanecem, a exemplo das explicações: mitológica, religiosa, psicológica e orgânica. Esses estudos contribuíram para esclarecer o lugar que a categoria da loucura ocupa, ainda hoje, tanto no campo científico como no imaginário social. Nem o passar do tempo, trazendo mudanças culturais e sociais, apaga essas formas distintas de compreensão da loucura que sobrevivem no decorrer dos séculos.

\subsection{Saúde-doença mental enquanto processo}

Parto do entendimento de que a saúde e a doença devam ser compreendidas como processo, pois estão vinculadas a situações singulares e complexas da existência humana que, por sua vez, tem um caráter dinâmico, contraditório, de poucas certezas. Esse entendimento nos remete a biografias, culturas, histórias, enfim a sujeitos sociais concretos, com suas trajetórias e mundos subjetivos que são muito mais do que sintomas, mais do que resultados obtidos em escalas padronizáveis, mais, talvez, do que possa dar conta uma ou outra concepção teórica, como sugere a epígrafe desse capitulo.

Compreendo, pois, a vivência de intenso sofrimento psíquico chamada na psiquiatria de "doença mental", como um processo que ocorre na vida da pessoa e que envolve o conjunto dos elementos que a constitui (quer sejam de ordem individual, familiar, política, religiosa, econômica,...), repercutindo na sua história pessoal, familiar e nas suas redes de relações,

\footnotetext{
${ }^{39}$ Entre os quais destaco: Foucault (1995), Castel (1978), Goffman (2001), Szasz (1976), Birman (1978, 1994), Pessotti (1994), Ferraz (2000) e Amarante $(1995,1996)$.
} 
transcendendo assim, os momentos pontuais que caracterizam uma situação mais específica da "crise".

Essa experiência é uma "condição humana" inerente à vida, geradora de sofrimento que produz determinadas rupturas entre o mundo interno e o externo, o dentro e o fora, provocando um descompasso entre o que é vivido pela pessoa e o que se espera dela naquela cultura, naquele momento social. Dito de outra forma, é uma situação de vida ou uma forma de produzir o mundo (pelo menos em determinados momentos) orientada por sistemas próprios de referência dificeis de serem compreendidos e compartilhados pelos demais, como a que descreve Sabiá, um de nossos sujeitos de investigação, ao dizer que começou a sentir que tinha poder absoluto sobre a terra e que ela estava cheia de bicho.

[...] aí eu coloquei um tapete na rua (continua ele), levei o rádio e fui lendo a biblia e limpando o porão. Eu tinha que deixar limpo até às onze da noite, eu tinha que aprontar um serviço. Ai as pessoas me atrapalhavam e eu ficava nervoso. Porque eu tinha, na minha cabeça, uma ordem que dizia que eu precisava deixar aquilo pronto. Ai para poder acabar eu quebrei uma caminha de nenê no porão e também quebrei umas partes do rádio.

Dona Giúlia, outra depoente, diz que sua filha Pomba-Rola não tinha nenhuma doença até aos 22 anos de idade:

[...] era boa e trabalhava 'de caixa' no mercado. Eu sei lá, ela saiu boa de casa e começou a colocar na cabeça que tinha que ir a Caxias. Morou numa pensão por dois meses e já voltou assim. Quem sabe até quando ela resolveu se demitir do mercado e ir prá lá, ela já estava ruim e a gente não se deu conta. Nós não tínhamos sossego. Ela não dormia, só falava sozinha, essas bobagens que ninguém entendia, dava risada sem motivo. Umas vezes até tentou me avançar.

Dona Rosa, mãe de João-de-Barro, faz questão de dizer que o filho não foi sempre assim:

[...] o shopping Bella Cittá foi ele que ajudou a construir, todinho. $E$ o patrão dizia que ele era um dos mais trabalhadores. Ele fez muitos trabalhos; até um tempo antes dessas crises 'brabas' ele já tava montando uma firma daqueles materiais de lavagem de carro, mas depois não deu. 
Com um pequeno álbum de fotografias, foi mostrando João-deBarro no trabalho:

Aqui ele tava bom. Como eu tava te dizendo, nesses últimos três anos que o João-de-Barro ficou com essa doença nós corremos muito. Ele deu prá avançar e quebrar coisas, principalmente vidros, não podia ver vidros que já soqueava e se ensangüentava tudo, mas ele sempre quis morrer (enche os olhos de lágrimas). Por três vezes ele tomou mais de 300 comprimidos e nós conseguimos levar rápido prá emergência do São Vicente (hospital), graças a Deus salvamos ele. No ano passado ele teve uma crise violenta. Eu peguei ele com um machadinho pronto pra cortar o punho, foi o que deu pra eu tirar e chamar meus filhos. Aquela noite nós passamos de vigília no pátio. Ele se batia, batia com a cabeça numa caixa de concreto. Depois sumiu, e nós não conseguimos segurar. Passamos procurando ele. Eu pensei que iam me trazer a notícia de que ele tava morto em algum lugar..

João-de-Barro sintetiza o que sente nesses momentos mais dificeis, dos quais ele próprio tem medo: me sobe uns nervos, aquela fúria, uma coisa que vem de dentro e parece que explode em mim. Eu não agüento e também não vejo mais nada. Tem horas que minha cabeça parece um cabo de guerra ${ }^{40}$. Tem um lado que quer viver e outro que não.

Conforme Lobosque (2001), esse dilaceramento subjetivo, que é a experiência da crise, afeta de forma distinta as pessoas que a atravessam, conforme expressam Sabiá, João-de-Barro, Giúlia e Rosa. Após a crise, quando aquilo que era insuportavelmente intenso já passou, muitas pessoas continuam em um "vazio sem fundo" expresso pela apatia, pela robotização, pelo bloqueio. Mas, há também, a dimensão da reconstrução:

Conseguir com a ajuda de um técnico, de um amigo, ou até sozinho, montar uma explicação para as vozes, mesmo que essa explicação seja ela própria delirante; recuperar uma relação que parecia perdida com a familia, ou perceber que, na impossibilidade de vida em familia, existem outros espaços legitimos de convivio e de afeto; fazer arte, procurar trabalho, definir políticas, participar de movimentos,... enfim, criar novas produções de sentido (LOBOSQUE, 2001, p.21).

Assim, se a "doença" é parte da história do sujeito e repercute no conjunto da vida, também acreditamos que ela não o desloca totalmente, 0

\footnotetext{
${ }^{40}$ Brincadeira em que cada grupo puxa uma das extremidades de uma corda. Vence o lado que conseguir mais força para deslocar o grupo de lugar.
} 
que significa reconhecer que o sofredor psiquico ainda que vivendo essa condição, apresenta saúde mental e/ou um potencial para ela, desde que não nos utilizemos de "métodos" de intervenção que dificultem ou até impossibilitem o seu desenvolvimento, o seu lugar subjetivo singular e, nem persigamos a racionalidade da normalidade plenamente restabelecida. Dessa perspectiva, também me parece inadequado o termo "portador", pois esse agrega a idéia de alguém que porta em si algo permanente e imutável, - que pode ofuscar a possibilidade de novas subjetivações e de novos sentidos que poderão advir no percurso de sua existência.

Compreender saúde-doença como processo significa dizer que, por um lado, o sofrimento envolve uma experiência que ocorre na existência da vida, não ficando circunscrito apenas ao corpo ou ao psiquismo, e nem ao momento da fase aguda, quando a manifestação de uma série de sintomas faz-se presente. O sofrimento está envolvido com os demais aspectos da vida, com os sistemas simbólicos, a significação para o sujeito que o vive e no contexto onde vive; a sua relação com o trabalho, com os direitos de cidadão, com a inclusão e a exclusão. Mas está, também, vinculado à idéia expressa na epígrafe desse capítulo, mostrando que, apesar do período de intenso sofrimento relatado pelo autor, tal situação não impede a existência de seus desejos de continuar acessando a trama do cotidiano, revigorandoa, querendo viver as possibilidades com um "punhado de estrelas maduras, sentindo a doçura do verbo viver".

Meu destaque para esses aspectos "positivos" da vida, vai no sentido de que se perceba que, na maioria das vezes, eles são encobertos, esquecidos ou desqualificados na relação do sujeito com os profissionais de saúde, nos modelos de atenção dominantes, quando, na verdade, parece que se constituem em canal, ponte de expressão e de expansão de possibilidades reais de vida, de saúde mental.

É nesse duplo sentido que concebo e emprego neste trabalho a idéia da pessoa em sofrimento psíquico, também sustentada na perspectiva basaglaina que será desenvolvida adiante. Embora entendendo que 
"sofrimento psíquico" é uma categoria ampla, presente em muitos momentos das nossas vidas, em diferentes intensidades e com significados singulares, chamarei de "pessoa em sofrimento psíquico", àquela que foi reconhecida no universo da pesquisa como "fora de si, doido, louco, doente da cabeça, que "não bate bem das idéias" (e tantas outras adjetivações). No transcorrer do texto utilizarei as diversas denominações para designar o estado vivido e descrito pelos sujeitos pesquisados.

\subsection{O sofrimento psíquico visto pelo campo "psi"}

\section{a) a psiquiatria}

Para falar dessa concepção, que é dominante no municipio, vou partir de uma reportagem (trata-se de entrevista com profissional da saúde) publicada em jornal da cidade, sobre as "filas de espera" para internação no hospital psiquiátrico:

Com o hospital [...] lotado, os doentes mentais estão sendo mantidos em casa. Como os familiares não mantêm o tratamento adequado, estes doentes estão saindo para as ruas e são encontrados circulando pela cidade. Um problema que se agrava a cada dia (ON, 26/04/2002).

Se a circulação do doente mental na rua se constitui em um "problema" para a cidade, estamos falando de uma sociedade que precisa se proteger desses cidadãos, segundo a concepção de quem detém o "discurso cientifico" e é responsável por tratar essas pessoas. Nesse particular, o discurso psiquiátrico revigora uma concepção de doença mental como periculosidade social (risco) e, portanto, vincula uma relação de tutela - a ser exercida através do hospital -, que permita controlar esses "insanos" e manter a cidade protegida, "higienizada". "A noção de periculosidade social, associada ao conceito de doença mental formulado pela medicina, proporcionou uma sobreposição entre punição e tratamento, uma quase identidade entre o gesto que pune e aquele que trata" (BARROS, 1994, 34).

Essa vinculação de risco é destacada no Plano Terapêutico do hospital especializado em psiquiatria, no município, que está equipado para 
atender "portadores de sofrimento psíquico maiores de dezoito anos". $\mathrm{Na}$ triagem é "priorizado o atendimento de quadros agudos com risco de agressão e/ou suicídio", inclusive explicitando normas e rotinas detalhadas para os primeiros: "pacientes agressivos/violentos". Tal seleção para a internação denota um comportamento e um tratamento prescritos para esses sujeitos.

Situação semelhante também é vivida por quem enfrenta essa problemática no cotidiano, confirmando que existe uma construção social a respeito da saúde e da doença mental que vai se estabelecendo através dessa conjugação. O meu primeiro contato com Raquel e João, familiares de Sabiá, internado no hospital, reflete bem o que estamos discutindo:

[...] quando ele começa assim com as loucuras dele, eu vou lá prá minha mãe com a minha filha, ou morro de medo que ele bata ou faça alguma coisa pior (embora isso nunca tenha acontecido).

O distanciamento entre Raquel e João de um lado, e Sabiá de outro, parecia ser maior do que a distância física que os separava. A única noticia que tinham dele era a que a vizinha trazia, embora Sabiá já estivesse internado há dois meses. Nenhum contato, nem por telefone. A cunhada disse que era muito longe prá visitá-lo, mas a dimensão simbólica dessa distância presente nos depoimentos reflete os sentimentos vividos pelos familiares e o desejo implícito de mantê-lo distante. Afinal, Sabiá havia desestabilizado a ordem familiar no momento da crise, provocando insegurança e medo, conforme reage o irmão: como vão soltar ele desse jeito, completamente fora? Essa questão pode ser pensada pelo seu oposto: era necessário prender, capturar até normalizar a condição humana de "ficar bom".

Para Jairo, vizinho e liderança comunitária, o Sabiá era um rapaz bom que, de repente, começou a ficar doente [...]. Já teve três crises e graças a Deus que conseguimos uma vaga prá ele em Caxias (Hospital Psiquiátrico). [...] não obedecia ninguém, só a mim que ele respondia [...] 0 rapaz, não dava mais, ele tava completamente fora-de-si' e não tinha ninguém (da familia) que pudesse tomar uma atitude. 
O promotor público faz referência às situações em que precisou intervir, ilustrando como tem atuado nesta área:

Tive um caso de um sujeito aqui em Passo Fundo que estava agredindo todo mundo do prédio, até que um dia ele pegou uma faca e queria 'cortar' todo mundo, num momento de crise...

Um outro caso de uma mulher de uns trinta anos, ela estava sozinha, queimando as madeiras internas da casa. Ela ia se incendiar lá, sem comer, porque ninguém faz comida para ela. A última pessoa que alcançou comida para ela foi agredida. Então, a pessoa não alcançou mais, aquela história toda...

Lembro-me bem de um que queria se matar num gabinete lá em cima, um guri de vinte e poucos anos, queria se matar. Daí, consegui, questão de pouco tempo, a internação dele.

O policial ligado ao policiamento comunitário do Vera Cruz designado para manter a ordem e o controle no local, também falou sobre a sua experiência. Destacou que o mais freqüente é a familia ou vizinhos solicitarem policiamento para resolver conflitos familiares, geralmente de filhos com os pais, por excesso de drogas e álcool. O filho está agressivo, batendo, quebrando tudo dentro de casa, ai nos chamam. Mas normalmente a gente descobre lá que está associado a drogas, porque isso eles não nos contam, só no limite! Outra situação freqüente é para ajudar a conduzir a pessoa com distúrbio ao hospital. Afirma o depoente que essa situação é, normalmente, "acalmada" com a chegada dos policiais ao local que promovem uma intervenção branda, embora, às vezes, em havendo resistência, nós imobilizamos, pois essas pessoas nunca acham que precisam ser internadas. Em casos mais graves, mais freqüente com usuários de drogas, a gente usa o carro com 'xadrez'.

O mesmo policial lembrou de um caso que atendera mais de uma vez no último ano: não lembro o nome dele; chamam de Bodão. Esse é completamente fora da 'casinha' (metáfora atualizada para o conhecido 'fora-de-si').

Esses depoimentos nos reportam à História da Loucura de Michel Foucault (1995) trabalho publicado na década de sessenta do século passado. Neste estudo, $o$ autor discute as relações entre a loucura e a 
sociedade, mostrando que, a partir de um determinado momento, o louco passou a ser excluído da sociedade, em parte, pela sua inadequação à vida social. A partir daí desencadeia-se o isolamento, inicialmente em prisões, até o aparecimento dos hospitais psiquiátricos e, posteriormente, outros espaços e modalidades "terapêuticas".

O autor apresenta a loucura como uma categoria histórica e socialmente construída; retoma a sua história nos séculos anteriores, destacando três importantes momentos: o primeiro marcado pela errância, quando a loucura era bem tolerada no meio social; o segundo que caracterizou como o da 'grande internação', quando esta se tornou o mundo da exclusão, e o terceiro marcado pelo nascimento da psiquiatria no final do século XVIII na França.

A psiquiatria, enquanto saber médico, passou a ter um papel fundamental no estabelecimento do que se vem chamando doença mental, constituindo suas categorias classificatórias (estatuto teórico) para identificála e tratá-la. A partir de então, foi assumindo, também, um papel de regulação do espaço social, através da disciplina e de regras de convívio para essa situação de vida, que "destoa" dos comportamentos socialmente aceitos. Esse padrão de conduta instituído pela psiquiatria é ainda marcante na atualidade como expressam nossos depoentes.

Se, por um lado, essa construção da psiquiatria propõe uma finalidade terapêutica, por outro, cumpre uma função de normatizadora do espaço social, através dos tradicionais equipamentos psiquiátricos (inicialmente os hospitais e mais tarde os ambulatórios e o trabalho comunitário de prevenção), ou dos modernos psicofármacos que permitem uma outra forma de controle das pessoas que se "desviam da norma".

Essa concepção - psiquiátrica ou orgânica - é a que ganhou força desde o momento em que a loucura passou a ser oficialmente objeto do campo da medicina sendo categorizada como doença mental. Ela pressupõe a existência de causas orgânicas (no sentido anatomofisiológico, bioquímico ou genético) como explicação proeminente ou última do adoecimento, tendo 
sido incorporada como discurso científico e desfrutado de um indiscutivel prestígio e legitimidade em nossa sociedade. $O$ francês Philippe Pinel ${ }^{41}$ foi quem marcou esse momento e foi responsável pelo reconhecimento da loucura enquanto doença, construindo um método próprio, que visava observar, descrever e classificar os alienados ${ }^{42}$ a partir dos seus sintomas. Afirmava que os hospitais eram os lugares apropriados para o conhecimento das doenças, porque ali, elas se expõem, juntamente com outras, favorecendo a classificação. Na condição de alienados essas pessoas recebiam a "proteção" do Estado que, paradoxalmente, - já que a cidadania pressupõe a inscrição das pessoas no universo da razão e da vontade - as impedia de participar do pacto social e da circulação no espaço da cidade. Desde então, estabeleceu-se importante nosografia, dispositivo que vem sistematizando os "transtornos psiquiátricos" até nossos dias e que traz no seu interior os mesmos principios alienistas que orientavam as condutas terapêuticas da modemidade/era pineliana.

Assistimos à forma contemporânea das concepções organicistas, a vertente biológica da psiquiatria que se encontra em plena expansão, buscando através das combinações genéticas, moleculares e bioquímicas, as justificativas para suas teses, inclusive trazendo ao cenário a valorização progressiva de alguns quadros psicopatológicos ${ }^{43}$. O que observamos é que essa valorização vem sempre acompanhada de ferramentas de diagnóstico e terapêutica. No primeiro caso, encontram-se os sofisticados "exames" de imagem que tornam possível identificar partes específicas do cérebro, cruzando informações neurofisiológicas; no segundo, a psicofarmacologia que tem se tornado o principal ingrediente dessa matriz sendo reconhecida em muitos setores como uma revolução na história da psiquiatria. Sem

\footnotetext{
${ }^{41}$ Ver FOUCAULT (1995) e AMARANTE (1996).

${ }^{42}$ Assim chamados a partir de Pinel. Alienação seria o ato de estar fora de si próprio, de tornar-se um outro, de perder a consciência de si e das coisas' (AMARANTE, 1996, p.4446). A loucura, nesse momento, é entendida como alienação, isto é, como o estado de contradição da razão, portanto como o estado de privação da liberdade, de perda do livre arbitrio. Ver também AMARANTE, P. Projeto Memória da Psiquiatria no Brasil: acervo de periódicos da Biblioteca de Manguinhos (Fundação Oswaldo Cruz). Disponivel em CD ROM.

${ }^{43}$ Tema abordado por Joel Birman na obra Mal-estar na atualidade: a psicanálise e as novas formas de subjetivação (BIRMAN, 2001).
} 
negar e sem diminuir a importância dessas descobertas, e, particularmente, dos fármacos, (inclusive para possibilitar ao "usuário" viver um nivel suportável de angústia que lhe permita interagir consigo e com os outros no seu espaço social), essas alternativas não podem responder a todas as necessidades vividas por esses sujeitos.

Entre as preocupações dessa orientação seguida pela psiquiatria está a atenção dirigida ao que Sampaio (1998) citou como o refinamento de instrumentos que, ao recortar sintomas, os tomavam pelas doenças, confundindo-os pela natureza imprecisa do objeto. Essa direcionalidade da atenção para os sinais e sintomas desse sofrimento, reescreveu a doença a partir de um comportamento desviante, estranho aos padrões normais. Tais questões tornam-se relevantes por se sobreporem a uma busca de compreensão do sujeito que sofre - que, por sua vez, é mediado pelo meio sociocultural -, habituando-se a classificar as manifestações do sofrimento segundo uma ordem natural (AMARANTE, 1996, p.43). A padronização daí decorrente produziu modos universais de pensar e lidar com essa condição de vida e suas condutas terapêuticas também padronizadas que buscam, prioritariamente, o retorno da normalidade através da regularização dos desvios.

A título de ilustração desse sistema classificatório, podemos citar o manual de classificação ${ }^{44}$, coordenado pela Organização Mundial de Saúde (OMS) que criou um instrumento de agregação de sinais e sintomas para definir categorias denominadas de transtornos mentais e comportamentais (CID-10). Na sua última versão, amplamente discutida por autoridades psiquiátricas do mundo inteiro, o termo "doença mental" foi substituido por "transtorno", abandonando aparentemente, a polêmica sobre a sua etiologia e restringindo-se à classificação baseada na descrição dos "aspectos clínicos principais" consensados. A compreensão de tais transtornos, geralmente, caracteriza-se por uma combinação de idéias, emoções,

\footnotetext{
${ }^{44}$ Classificação dos Transtornos Mentais e Comportamentais, décima versão, CID 10 coordenada pela Organização Mundial da Saúde -OMS (1993).
} 
comportamento e relacionamentos anormais com outras pessoas" (OMS, 2001).

Essa padronização apresenta um caráter eminentemente orgânico, embora os aspectos "psicossociais" componham os cinco eixos ${ }^{45}$ do sistema classificatório. Insisto no caráter orgânico, sobretudo pelo entendimento de que o "funcionamento mental tem um substrato fisiológico e está indissociavelmente ligado ao funcionamento físico e social [...]" (ORGANIZAÇÃO MUNDIAL DA SAÚDE, 2001, p.29) estes, reiteradamente repetidos pela psiquiatria tradicional, "aparecem" (quando aparecem) de forma suplementar sem que tal situação provoque qualquer modificação no trabalho terapêutico. $O$ entendimento de que o sujeito apresenta um delírio de controle ou uma alucinação visual dá-se porque esses sintomas são desencadeados pelo aumento ou diminuição de determinados neurotransmissores, caracterizando "tal quadro psicopatológico". Se não o entendermos como forma de relação entre esse sujeito e o mundo, corremos o risco de torná-lo dicotomizado e sem sentido. Portanto, essa padronização vai deixando de ser uma experiência para a qual é necessário buscar sentido, tomando-se um instrumento insuficiente, freqüentemente utilizada de forma preconceituosa e discriminatória, e de pouca relevância para uma melhor compreensão sobre as densas e ricas histórias do mundo subjetivo.

Concordo com Sampaio (1998, p.105), de fato, "a doença mental tem sido tomada (pela psiquiatria) descritivamente numa taxionomia estática baseada em síndromes desligadas da história; em imputação de relação causal através da lógica causa-efeito imediatizada [...]".

O programa de atendimento do hospital especializado em psiquiatria do município de Passo Fundo é pautado por uma avaliação técnica individual (Médico Psiquiatra e Clínico, Enfermagem, Psicologia, Terapia Ocupacional, Nutrição, Serviço Social e Farmacêutica), com vistas à

\footnotetext{
${ }^{45}$ Eixo I - Transtornos psiquiátricos gerais. Eixo II - Condições de desenvolvimento; Eixo III Condições fisicas concomitantes; Eixo IV - Situaçōes psicossociais anormais (educação, emprego....); Eixo $V$ - (incapacitações em autocuidado, no trabalho, nas relações com a familia, nas relações sociais em geral.
} 
formulação diagnóstica segundo o CID para, posteriormente, estabelecer um "plano terapêutico individual que é informado e proposto ao paciente"46.

Tais passos são pouco perceptíveis na vida dos nossos protagonistas que retornam muitas vezes para internação psiquiátrica, a fim de "conter a crise". Sabiá, que viveu momentos difíceis nos últimos três anos, com sucessivas crises e internações permaneceu grande parte desse tempo em hospitais psiquiátricos, inclusive fora da cidade e comenta:

[...] eles me observavam e davam remédio, os enfermeiros
avisavam o doutor, ou, quando eu tava com aqueles repuxos, aí
eu falava e eles me davam um remédio pra combater. Depois de
uns dias me botaram prá ajudar a cuidar dos outros, ajudar os
enfermeiros. Mas, assim..., doutor que conversa com a gente é só
pra saber se eu ainda ouvia essas coisas que me atentavam l...]
a psicóloga me disse que tenho um problema na cabeça e que
tem que tomar remédio prá sempre porque não tem cura, eu sei
lá...

Situação semelhante é vivida no plano ambulatorial. Fui ao Centro de Saúde para encontrar João-de-Barro e encontrei, também, Sabiá e seu irmão. Todos na sala de espera, muito quietos, aguardando a vez para a consulta com o psiquiatra. Sentei-me ao lado deles e iniciei a conversa. Sabiá me diz que veio "pegar a receita", pois o remédio havia acabado. Pensei no significado do "pegar a receita" e me dei conta de que, de fato, eles não esperavam mais do que isso. Afinal, parece que já se haviam acostumado à situação, como confirmou o irmão de Sabiá ao sair da sala do psiquiatra, na condição de acompanhante e respondendo à minha pergunta de "como foi a consulta?": Ele só perguntou se tava sentindo alguma coisa, fez a receita e pronto. Não é uma 'consuulta'. Focalizada no sintoma, ou em um olhar que não aposta no sujeito, a fala é recolhida a titulo de quantificar a dose medicamentosa e a consulta resume-se à receita, que é transcrita para mais uma temporada.

Chegada a vez de João-de-Barro, foi inevitável ouvir parte de sua conversa com o médico psiquiatra, pois ele falava alto. Exigia do médico um "atestado" para comprovar a necessidade de remédios cuja quantidade

\footnotetext{
${ }^{46}$ Plano Terapêutico do referido hospital.
} 
estava sendo contestada pelo neurologista. Imaginava que o "atestado" seria a melhor forma de fazer com que psiquiatra e neurologista se entendessem sobre o seu caso, porque, segundo ele, esta falta de comunicação entre os dois médicos foi responsável por uma de suas internações, já que "quase" não conseguia andar devido à sobrecarga de remédios. Saiu desanimado do consultório, com as receitas na mão, perguntando-me o que fazer e sem ter conseguido a "aproximação" entre os dois profissionais, que ele julgava ser uma saída para o seu tratamento naquele momento.

É curioso observar como o discurso psiquiátrico foi "artificializando" as relações com o sujeito que sofre, através de uma suposta categorização que, de antemão, traduziria sua "doença". Os sintomas transformam-se em um conjunto de itens objetivos para justificar o tratamento que consiste na tentativa de restituição da normalidade. Assim, o sofrimento torna-se uma disfunção para a qual basta achar um regulador físico (isolamento) ou químico (medicamentos), mesmo que o "usuário" manifeste o desejo de participar ativamente do tratamento e ofereça elementos para o seu próprio processo de reabilitação.

A partir dessa mesma perspectiva ganha significado a expressão "fora-de-si" trazida com recorrência nos relatos de familiares e vizinhos, para marcar os momentos mais difíceis da situação vivida pelas pessoas em sofrimento psíquico. $\mathrm{O}$ "fora-de-si" é representado, primeiramente, por uma condição em que alguns padrões (tentativas da auto e heteroagressão, não dormir à noite, não obedecer,...) se repetem, confirmando uma espécie de "desconhecido" ou não reconhecido. Na expressão dos depoentes, muitas vezes uma gesticulação típica também simboliza ou traduz essa interpretação: os movimentos circulares com o dedo indicador ao lado da cabeça, por exemplo, o que significa ainda a perda significativa da confiança naquilo que a pessoa fala ou faz.

Se pensarmos o "fora-de-si" pela constituição do seu oposto, talvez teremos a noção mais próxima do que essa pessoa não é, ou não está: dentro de si, uma situação que parece falar de algo descentrado do sujeito, 
do seu eu. Birman, (2001) ao fazer a análise do fora-de-si ${ }^{47}$, auxilia-nos nessa discussão. Nas representações da loucura oriundas do modelo da psiquiatria, a categoria fora-de-si caracterizou-se, historicamente, pela inexistência da interioridade do sujeito e pelo descentramento (perda de seu eixo de ordenação), inscrevendo-o na ordem da negatividade, de um discurso sem valor e de um estado mental que não condiz com as regras mínimas de sociabilidade. Interiorização e autocentramento são, portanto, nesse modelo, atributos para definir sujeito e saúde mental. Assim, o sujeito desgarra-se do dentro-de-si, inserindo-se no exterior, espaço que não suporta essa exteriorização e descentramento (marcado pelo estranhamento, pelos "sintomas", pelo fora dos padrões) e o envia para um lugar especial como a internação psiquiátrica com a pretensão de inseri-lo novamente dentro-de-si e no espaço da sociabilidade. Esse modelo psicopatológico naturalizado que vem desde a constituição do discurso psiquiátrico das psicoses instituiu e reproduziu uma visão individualista do mundo.

Na mesma linha de pensamento, Sampaio (1998, p.99) afirma que, "se a psicopatologia puder superar o estágio em que se encontra, terá de perseguir o homem por onde o homem se faz", ou seja, terá de considerar os aspectos sócio-histórico-culturais corno constitutivos e não atribuir a origem e a responsabilidade do adoecimento ao indivíduo e de um ponto de vista interno (seja orgânico ou intrapsíquico).

Saraceno (1999, p.33) diz que o diagnóstico psicopatológico "[...] deve nos ajudar a compreender que as informações (as variáveis) que o paciente carrega consigo e que é o que nós podemos efetivamente considerar como patrimônio, (de risco ou de proteção) estão na realidade mais conectadas à vida do paciente do que à sua doença, cuja identidade

\footnotetext{
${ }^{47} \mathrm{O}$ autor argumenta que na atualidade deparamo-nos com uma nova modalidade de sujeito fora-de-si que não é representado pelos quadros da psicose, nem retirado da sociedade para inseri-lo novamente dentro-de-si; ao contrário, é socialmente integrado, valorizado e legitimado. É nessa direção que o autor discute a psicopatologia contemporânea que "se caracteriza por certas modalidades de funcionamento psicopatológico, nas quais é sempre o fracasso do individuo em realizar a glorificação do eu e a estetização da existência que está em pauta" (BIRMAN, 2001, p.168).
} 
autônoma da vida é um artefato da clinica". Assim, estamos diante de uma complexidade de variáveis reais, quais sejam: os sujeitos, os contextos, os serviços e os recursos, de maneira que

[...] não é conhecivel pelo outro um sujeito em si e, portanto, uma doença em si, mas somente colhem-se interações psicológicas e materiais [...]. São essas interações operativas (entre paciente e outros, entre paciente e vida material, entre paciente e as respostas que ele recebe, entre paciente e lugares) o patrimônio ao qual podemos ter acesso e que se pode modificar sob a força de uma intervenção que crie as condições para que o sujeito possa exercitar mais escolhas (SARACENO, 1999, p.93-94).

Portanto, estamos diante de elementos pouco ou, dificilmente, padronizáveis e impossíveis de serem "plugados" ao determinismo orgânico e/ou, por vezes, moral. Esse tipo de construção elaborada através de métodos muito criteriosos, de grande investimento nessa concepção teórica, dá um caráter de homogeneização que dificulta a distinção de singularidades, particularmente em uma situação humana que é inerente à vida social e, como tal, não pode ser universalizada. Desse prisma, há uma multiplicidade de sentidos e práticas que não podem ser evidenciadas nessas classificações. Para falar em vida social, parafraseando Magnani (2002), é preciso uma abordagem "de perto e de dentro", "para além do olhar competente" que decide os quadros mórbidos e os recursos necessários para as suas terapêuticas, que, por conseqüência, também ocorrem, predominantemente, afastadas do contexto social.

É nessa direção que busco subsídios em Marilena Chaui (1990) para melhor entender esse processo que coloca o conhecimento presente na ciência contemporânea como inquestionável e universalizante. Chauí faz referência a aspectos importantes na construção do saber, considerando tratar-se de um trabalho para tornar inteligivel a indeterminação, a obscuridade da experiência, ou seja, Marilena Chaui (1990, p.5) defende a idéia de que "só há saber se a reflexão aceita o risco da indeterminação que a faz nascer, quando aceita o risco de não contar com garantias prévias e exteriores à própria reflexão que a trabalha". 
De outro lado, aponta um caminho peculiar do conhecimento que, para ser eficaz, busca ocultar o que não tem um significado preciso, o que abre lacuna para as dúvidas, contradições, incertezas, para o não-saber que habita na experiência. Neste, as idéias assumem a forma de idéias instituídas. Como tal, essas idéias estão "fora do lugar" e "fora do tempo" (embora a serviço da dominação presente), pois passam a ser veiculadas e apreendidas como independentes da realidade histórica e social, sendo tomadas como determinantes do processo histórico, quando, na verdade, na concretude da vida, são por ele determinadas.

É o que a autora chama de discurso competente.

[...] é o discurso instituido. É aquele no qual a linguagem sofre uma restrição que poderia ser resumida: não é qualquer um que pode dizer qualquer coisa em qualquer lugar e em qualquer circunstância. $O$ discurso competente confunde-se, pois, com a linguagem institucionalmente permitida e autorizada, isto é, com um discurso no qual os interlocutores já foram previamente reconhecidos, como tendo o direito de falar e ouvir [...] (CHAUÍ, 1990, p.7).

Nessa linha de raciocínio, a psiquiatria também é mediadora desse "discurso competente" que se interpõe entre o individuo e a sua experiência de vida. Apoiada em Chauí, Maria Cristina Machado (1995) discute o discurso cientifico da psiquiatria como o principal representante do discurso competente, na medida em que a interpretação do real reflete, racionaliza e defende interesses da ideologia dominante. Defende que o discurso "científico" da psiquiatria tem adquirido status social, um poder autorizado socialmente, como o discurso do conhecimento, em detrimento de todos os demais saberes que não lhe forem adeptos. Esses últimos, considerados como inferiores e incompetentes, são excluidos do cenário das pessoas, o que constitui um dos pontos críticos dessa perspectiva que se construiu em torno da doença mental, pois resulta em um estreitamento do campo simbólico e de todo o potencial criador, instituinte e crítico do sujeito.

Basaglia também põe em evidência a doença mental como uma produção intelectual, um objeto construido pela psiquiatria que, ao produzir 
esse conhecimento, imprimiu-lhe, também, um caráter ideológico. Amarante, citando o autor, diz:

[...] esta objetivação do homem em sindrome, operada pela psiquiatria positivista, tem tido conseqüências extremamente irreversiveis do doente que - ordinariamente objetivado e restrito aos limites da doença - foi confirmado como categoria fora do humano por uma ciência que devia distanciar-se e excluir aquilo que não estava em grau de compreender (1996, p.82).

Existe, portanto, um aspecto ideológico subjacente à racionalidade supostamente fundada no discurso cientifico da psiquiatria clássica que se contrapõe à existência dos sujeitos, negando-lhes a possibilidade de manter suas identidades, retirando-Ihes a condição de sujeito de desejos, revelandoos objetos de uma relação e, ainda, dando-lhes um lugar especifico, afastado do contexto social em que vivem. O sofrimento torna-se uma abstração, uma maneira de afastar a sociedade de situações que the possam causar mal-estar, afastando-a, dessa forma, também, da ação concreta da realidade na produção e manutenção desse sofrimento. Esse processo revela o conteúdo ideológico embutido nessa relação, na qual nominamos um outro para nos isentar das contradições que são produzidas na organização social.

O trabalho de Basaglia, já na década 1960, toma como significativa essa dimensão da construção da doença, demonstrando o quanto esse processo foi relegando, aprisionando e dando ao sujeito um status social de excluído: "A definição da síndrome já assumiu o peso de um juízo de valor, de um rótulo, que vai além do significado real da própria enfermidade. $O$ diagnóstico tem o valor de um juizo discriminatório [...]". A "[...] ciência que, sempre a serviço da classe dominante, decidira que o doente mental era um individuo incompreensivel e, como tal, perigoso e imprevisivel, impondo-Ihe como última alternativa a morte civil" (BASAGLIA, 1991, p.2829, grifo nosso).

Esse processo ocorre na micropolítica do cotidiano e vai sendo interiorizado no imaginário de uma forma muito difusa e sutil, induzindo o conjunto das pessoas a incorporarem essa competência sob a ameaça de 
se não o fizerem, sentirem-se incompetentes, desqualificadas enquanto sujeitos integrados numa estrutura social, em um sistema de pertencimento e de credibilidade. Assim, essa incursão médica sobre a "doença mental" deixou pouco espaço para a compreensão do sofrimento segundo uma interação mais complexa com outros fatores que compõem a existência.

Os protagonistas, ao viverem a experiência do sofrimento psíquico, referem-se a uma condição que os torna "outro", ou seja, o que se destaca na convivência com a sociedade é a sua condição de doença. Exemplo disso foi o que aconteceu com João-de-Barro, um de nossos sujeitos de investigação, quando quis retomar os estudos e foi impedido, pois a escola obteve informação do seu "diagnóstico" e do suposto "risco" de tê-lo como aluno: eu quero fazer as coisas, aprender, poder trabalhar, eu vejo que já posso, mas todo mundo me imprime, me imprime (quis dizer oprime, mas olhando metaforicamente, imprime também expressa significado na fala: marcar ou ser marcado sobre algo, por meio de pressão). Esse é o atributo de reconhecimento sobre o qual se estabelecem as relações, mesmo que a pessoa tenha superado suas crises. Os relacionamentos afetivos, as possibilidades de trabalho, enfim, o cotidiano passa, muitas vezes, a ser mediado por esse "rótulo", reduzindo, efetivamente, as possibilidades de trocas e de credibilidade.

Essa situação é fortemente evidenciada também na vida concreta das pessoas "portadoras de esquizofrenia" e estudadas recentemente por Cintra que dizem: "[...] se tivesse uma propaganda que a gente não morde, que a gente tem um monte de sentimento, tem um monte de coisa... Eu tenho um sentimento de rejeição muito grande porque o pessoal confunde como piada" (CINTRA, 2001, p.90 e p.96). Situações exemplares foram vividas em nosso campo de pesquisa, como o caso citado no inicio deste trabalho, da colega que, ao tomar conhecimento dos sujeitos que eu estava disposta a pesquisar, sugeriu que eu procurasse outras pessoas para entrevistar, pois com essas, eu estaria perdendo meu tempo. 
Reações de mesmo teor vieram de familiares de pessoas com sofrimento psiquico. Chegaram a me perguntar o que eu poderia aprender com aquela pessoa, já que da sua conversa não se aproveita quase nada. Olhares e gestos de familiares indicavam que eu não deveria levar a sério $o$ que o sujeito dizia; de um lado afrontando-o e, de outro, pondo em dúvida a minha própria credibilidade, quando me consideravam como alguém que "dá ouvidos" a quem deve ser ignorado.

Percebe-se um processo de violência na base dessa relação entre quem tem e quem não tem poder, ou seja, a comunicação entre o "doente" e o "não doente" ocorre através desse "filtro" (os sintomas, a dissonância, o rótulo,...), deixando poucas possibilidades para que o sujeito tenha credibilidade em quase todos os aspectos da vida, condicionando-o a ocupar outro lugar na dinâmica social - o lugar do estigma ${ }^{48}$ e do preconceito -, ou seja, atribui-se-lhe um sinal infame que o torna alvo de desprezo, desqualificando-o como ser humano.

Essa concepção sobre o sujeito que sofre, predominante na psiquiatria, produz um circuito com novos processos de sofrimento. Esse lugar de "descrédito" é evidenciado por Basaglia (1991, p.106) que o destaca como a falta de "poder contratual do doente". No meu entendimento, essa questão continua como uma das mais complexas do lidar cotidiano porque requer uma (des)construção no conjunto de todas as relações que se estabeleceram em torno da loucura e sobre a qual falarei mais adiante.

Machado (1995, p.264) afirma que o saber psiquiátrico tradicional encobre a realidade social e política, visando também "[...] obter docilidade e conformismo por parte dos dominados, ameaçando-os com a possibilidade de doença mental caso não sigam os padrões de comportamento socialmente prescritos".

O sentido da expressão reiterada "não me fale de hospital" trazida por um dos nossos protagonistas traduz o drama de quem vive a experiência

\footnotetext{
${ }^{48}$ Erving Goffman desenvolve essa temática em sua obra Estigma (1988).
} 
do sofrimento psíquico e é submetido ao tratamento psiquiátrico e às suas conseqüências. Significa uma concepção do que seja a doença mental na psiquiatria: o rompimento com o sujeito e a sua subjetividade, a dificuldade de perceber sua configuração histórica, social e cultural e os cenários sociais em que vive. Em nome desse complexo, simplifica-se o outro por meio de marcas universais como se, através delas, pudéssemos conhecê-lo e tratálo. Ao imprimir-lhe estas marcas também se the impõe um lugar social de excluído da participação em diversas áreas da vida.

\section{b) a psicologia}

A psicologia enquanto ciência que também se dedicou a cuidar da subjetividade, vem se configurando e se (re)configurando na busca de compreensão do seu "objeto". Para González Rey (2003, IX), a subjetividade é entendida como "um complexo e plurideterminado sistema, afetado pelo próprio curso da sociedade e das pessoas que a constituem dentro do contínuo movimento das complexas redes de relações que caracterizam o desenvolvimento social".

No entanto, diferentes compreensões dessa ciência estão fundamentadas em estudos que se constituíram ao longo da história, definindo seu foco de atenção no comportamento (Behaviorismo), no inconsciente (Psicanálise), na inteligência e na aprendizagem (Cognitiva) e na configuração histórica e social do sujeito - e do seu mundo subjetivo - e seus cenários sociais (sócio-histórica ou histórico-cultural), para citar alguns exemplos de seus marcos teóricos. Essas tendências proporcionaram inúmeras abordagens e interpretações sobre o ser humano no decorrer da história, podendo ser utilizadas em múltiplas direções, com conseqüências e resultados bem distintos, como, por exemplo, pôr-se a serviço do cuidado e da emancipação dos sujeitos em sofrimento psíquico ou, constituir-se em ferramenta disciplinar e normalizadora.

No âmbito mais geral dessas diferentes concepções utilizadas pela psicologia, a psicanálise ganha mais evidência no campo da saúde mental. 
González Rey (2003, p.31) destaca que entre os elementos importantes dessa linha teórica está a atuação, pela primeira vez, "no domínio da enfermidade por meio de técnicas psicológicas".

A virada freudiana (termo usado por Ferraz) surge em meio a um discurso predominantemente organicista e passa a dar um novo sentido ao sujeito e à loucura, num período de forte influência da psiquiatria. É com a psicanálise freudiana que se abrem novas possibilidades para pensar 0 sofrimento psíquico. Nela, a base psicológica ganha uma dimensão central, consagrando-se nas ciências da mente.

\begin{abstract}
O discurso freudiano, ao colocar o sujeito implicado no seu delírio, inaugurou um novo paradigma para a sua compreensão, recolhendo-o do lugar de resíduo de uma doença - que em última instância se situa no domínio do corpo biológico - para compreendê-lo como trama que se tece no domínio da linguagem. $O$ delírio, assim, deixou de ser - ao menos para a psicanálise - um erro de entendimento que surge em conseqüência de uma perturbação do corpo sintomático, ou seja, uma espécie de defeito da razão que faz dele uma produção sem sentido (FERRAZ, 2000, p.91-92).
\end{abstract}

Dessa forma, a psicanálise, através de sua teoria, aborda a formação psicopatológica como sendo resultante, fundamentalmente, de manifestações do complexo mundo inconsciente interconectado com a história de vida do sujeito. Por meio dos conteúdos dele emanados a psicanálise pôde dar um novo sentido ao que antes ficava no campo da (des)razão, valorizando-o e entendendo-o como possibilidade de reconstrução de um processo de sofrimento, talvez a única maneira possível de expressão em determinados momentos da vida.

A "metodologia" freudiana (a escuta dos sonhos, dos atos falhos, etc.) de leitura do mundo dos sentidos era bastante ousada para a época, quebrando, de certa forma, a linearidade do pensamento lógico dominante e da valorização do mundo das idéias. 
De outro lado, o francês Felix Guattari ${ }^{49}$, crítico da psicanálise tradicional, argumenta que essa trajetória se transforma em um longo empreendimento de reduções, da qual destaco sua análise crítica da redução do mundo inconsciente a certos modelos psicanalíticos (redução da representação do inconsciente psicanalítico a um certo triangulo familiar, por exemplo). Estabeleceu-se uma "modelização dominante", em que cada fase da vida estaria associada a determinadas figuras familiares (de identificação, de controle, de integração e submissão ao mundo dos valores), a partir das quais, seria estabelecida a capacidade de dar sentido a sua existência, limitando outras leituras de produções do desejo. Com isso, o autor argumenta que a matéria prima da experiência psicanalítica que leva em conta a singularidade do inconsciente, se institucionaliza em modelos fechados, deixando pouco espaço para os diferentes modos de produção de sentido presentes no contemporâneo e que, qualquer modelo, é sempre a cartografia de determinada formação do inconsciente. $O$ inconsciente é considerado "como uma produção singular de enunciados, de afetos, de sensibilidade, sempre resultante do entrecruzamento de diferentes agenciamentos" (GUATTARI, 2002, p.220). Com isso, o autor alerta para a importância de se preservar a possibilidade de uma escuta dos diferentes modos de produção do inconsciente, de tal modo a não reduzi-lo a um único modelo.

\begin{abstract}
A lógica do inconsciente é arrastada em relação a uma espécie de matéria indiferenciada, [...]. Uma perspectiva genética [...] irá substituir a relação entre as instâncias psíquicas enquanto diferentes contingentes lógicos, enquanto diferentes maneiras de semiotizar essas realidades. Desse ponto de vista, as instâncias psíquicas irão se engendrar umas a partir das outras num processo geral de amadurecimento, e - por quê não dizê-lo? - de normalização. Em outras palavras, temos uma espécie de corrida
\end{abstract}

$49 \mathrm{Na}$ obra que produz conjuntamente com Gilles Deleuze, o Anti-Édipo (tradução Brasil: 1976) desenvolvem a teoria crítica. Em Revolução Molecular. pulsões políticas do desejo (tradução Brasil: 1987), Guattari aprofunda o que hoje chamamos de "globalização", o Capitalismo Mundial Integrado e as suas repercussões na produção da subjetividade. A partir de uma releitura da psicanálise no mundo contemporâneo, o autor desenvolve a "corrente" de pensamento conhecida por "esquizoanálise". Uma referência dessa corrente no Brasil é o grupo coordenado por Sueli Rolnik (PUC/SP). Destaco ainda o trabalho da "Equipe de Acompanhantes Terapêuticos" da Casa -SP que também se utiliza desse referencial ao desenvolver o trabalho com psicóticos, deficientes e outros sofrimentos psíquicos no espaço da cidade. 
de obstáculos, que vai permitir a integração Ego, às normas do Ego, às normas dos valores sociais, às normas dominantes (Guattari, 2000, p.205).

A intenção desses autores foi evocar a idéia de análise do desejo, da singularização, sem reduzi-los ou encaixá-los às tendências dominantes.

Ferraz (2000), Machado (1995) e Guattari (2000) consideram que Freud dá ênfase aos acontecimentos da vida enquanto processos geradores de sofrimento psiquico. No entanto, brechas na própria estruturação da psicanálise e o desenvolvimento de diferentes vertentes dela decorrentes permitiram que muitas das idéias freudianas fizessem o mesmo caminho da parcialidade e fragmentação da perspectiva orgânica, porém, localizando a doença mental no âmbito intrapsíquico.

A noção de realidade psíquica, inicialmente entendida "como uma elaboração pessoal a partir dos dados da realidade, à medida que a teoria é (re)construida passa a ser tida como prevalente sobre a realidade externa e fruto do conflito perpétuo entre as pulsões [...], anulando e dissimulando a importância do contexto histórico social no qual o homem vive e se desenvolve." Com base nessa premissa, o discurso psicanalítico também se constitui enquanto "discurso competente na medida em que situa a doença num psiquismo perturbado pelo conflito entre as pulsões e mascara a realidade concreta vivida por pessoas portadoras desse sofrimento" (MACHADO, 1995, p.16-19).

No entanto, encontramos leituras contemporâneas da psicanálise e de outras correntes psicológicas e psiquiátricas no campo da saúde mental que não se encontram alinhadas a esse discurso competente. Ao contrário, buscam colaborar com o sujeito na reconstituição da "competência perdida" (nos termos de Chaui), ou de um lugar subjetivo singular em função das circunstâncias inerentes à sua existência e propõem meios que favoreçam novas possibilidades de interlocução e de sentido para suas vidas. Nessa direção, alguns trabalhos realizados com pessoas em sofrimento psíquico, recentemente no Brasil, são exemplares. Podemos citar os trabalhos da 
Equipe de Acompanhantes terapêuticos A Casa (1991, 2000), de Goldberg (1996), de Melman (2001), de Lobosque (1997, 2001, 2003).

Embora muito dos saberes psiquiátricos e psicológicos estejam presentes, ao mesmo tempo, na prática dos profissionais de saúde mental, foi difícil discriminar um discurso psicológico propriamente dito no cotidiano da pesquisa. É preciso dizer que a concepção organicista, assim como a forma de organização do trabalho psiquiátrico tradicional exerceram (e ainda exercem) grande influência nessa área, tornando-se mandatos sociais hegemônicos, o que talvez justifique em parte essa dificuldade.

Chamo atenção nesse momento para determinada organização institucional na saúde mental que expressa, em alguma medida, esse mandato social. Muito embora os planos terapêuticos das instituições de saúde mental reiterem a avaliação "biopsicossocial" ou "psicossocial" há uma centralidade no saber e na prática médicas - mais especificamente orgânica - de tal forma a deixar os demais saberes em posição secundária e dependente dela.

Essa centralidade reforça no cotidiano das instituições o estabelecimento de relações de trabalho que permitem privilégios e ações pouco integradoras como, por exemplo, a atribuição de um status "superior" ao médico, dando-lhe determinados regalias como é o caso do horário de permanência na instituição que se resume ao período das consultas (revisão medicamentosa), liberando-o de participar de outras atividades diárias e da rotina do trabalho. $\mathrm{Na}$ verdade, esses "privilégios" nada mais são do que fatores impeditivos de ações que poderiam, de fato, construir novos sentidos na relação com o seu mundo subjetivo, na relação com os fármacos, com a familia, com a sociedade. Ações que investissem na participação e no desenvolvimento de projetos terapêuticos baseados na emancipação, na ampliação da autonomia, na liberdade do sofredor psíquico. Essa é uma das contradições encontradas que em um dos dispositivos de atenção psicossocial freqüentados pelos sujeitos da pesquisa. A atenção psicossocial no contexto da reforma psiquiátrica deveria congregar um conjunto de 
práticas substitutivas ao modelo manicomial de modo a engendrar movimentos inovadores de produção subjetiva, de trocas afetivas e de sociabilidade. Um exemplo que bem ilustra o que estamos discutindo pode ser encontrado quando alguém é encaminhado ao serviço e chega fora do horário de atendimento médico e recebe a orientação de retornar outro dia ou procurar outro serviço porque "o médico já foi embora". Essa diretriz relativa à "assistência prestada" é explicitada também no projeto de referido serviço: "os usuários serão avaliados por um psiquiatra e, posteriormente, a equipe fará o plano terapêutico [...]. Esta equipe fará o acompanhamento do plano terapêutico e comunicará (o encaminhamento) ao paciente e à família" (PASSO FUNDO, 2000). Na verdade, além da centralidade do saber médico, destaca-se ainda a hierarquia de poder que perpassa essas relações em que o sujeito e seus familiares participam como "seres passivos", designados a receber um "pacote terapêutico".

Tomando o cotidiano do mesmo serviço alguns indícios podem sinalizar uma prática centrada na normalização e disciplina, exatamente porque um dos objetivos da instituição, mesmo que não explicitado em documentos, refere-se à "adequação" do comportamento do sofredor a um padrão "normal" estabelecido, ou seja, adequação a um conjunto de prescrições produzidas "externamente". É possivel perceber que a instituição tem dificuldades para lidar com os limites, com a diferença, com o fato das pessoas em sofrimento psíquico realmente terem uma conduta que escapa às formas sociais a que estamos "conformados" e que, por vezes, no dizer de Carrozzo (2000), "implode o sujeito e seus valores".

Como exemplo dessa prática, registro o que disseram, diversas vezes, nossos protagonistas sobre a privação temporária do uso do serviço, por descumprirem determinadas regras estabelecidas pelos técnicos. Quando esses "usuários" falam do serviço, é interessante notar como identificam com detalhes as marcas dessa relação que thes desagrada e que não Ihes permite sair dos trilhos, pois, "se sair é suspenso". Parece haver um comportamento esperado e pré-estabelecido pela instituição que lança mão de estratégias de reforços e punições sobre os "usuários" nas atividades de 
atenção diária, a exemplo das Instituições Totais descritas por Goffman (2001) onde se exercia uma autoridade sobre os internos, impondo-lhes normas do tipo "escalão", com utilização de sanções corretivas (controle de condutas, maneiras, intercâmbios sociais...) nas diversas esferas de vida, reforçando para si e para suas famílias que apresentam "comportamentos desadaptados". Não estamos aqui negando a importância do cumprimento das regras, mas queremos enfatizar que parece haver uma tendência acentuada na aplicação dessas regras que não leva muito em conta as especificidades de conteúdo das "transgressões", nem suas conseqüências. Assim, a suspensão pode-se dar porque alguém entrou na cozinha e "roubou" algo para comer, porque discutiu com uma usuária, porque danificou o patrimônio, ou ainda, porque discordou de alguma regra de internação.

Ao retomar os critérios de baixa (ingresso) e alta ${ }^{50}$ nesse mesmo serviço, percebe-se certa preocupação por parte dos seus proponentes, em estabelecer serviços e regras para que o "usuário" se insira, adeqüe/adaptese ao serviço, o que denota certa distância da compreensão subjetiva dos processos psíquicos como o proposto por González Rey (2003). Para esse autor, compreender o processo psíquico implica em perceber que o sujeito se constitui e é constituído dentro do contínuo movimento das complexas redes de relações. Estas redes de relações podem estar colocadas em detrimento de outras intenções, como a de estabelecer um comportamento "aceitável" e controlável, empobrecendo a sofisticação de temas complexos que se constroem exatamente nessas interações. Tal constatação parece permear a proposta da assistência que "convida" o "usuário" à "enquadrarse" a ela, ao invés de adequá-la as suas necessidades. Assim, a adequação

\footnotetext{
50 "Critério de baixa: os pacientes portadores de sofrimento psíquico que, depois de serem avaliados pela equipe técnica, e em concordância com ela, podem se beneficiar dos serviços oferecidos. Pacientes que mesmo sendo portadores de sofrimento psiquico conseguem se adequar às regras mínimas de convivência e funcionamento do Caps" (grifo meu).

"Critério de alta: Após reavaliações sistemáticas [...] definem, a partir do desenvolvimento do PTI (projeto terapêutico individual) a evolução do paciente em relação à patologia, capacidade de adequação à realidade, controle de impulso e re inserção social e ocupacional" (grifo meu).
} 
à realidade, às regras mínimas da sociedade parece refletir mais o processo de disciplina e normalização do mandato social e menos o direito do sujeito a ser respeitado na sua diferença.

Por outro lado, é perceptível o esforço de alguns profissionais para qualificar as relações com os "usuários", investindo técnica e afetivamente nas singularidades, a fim de atender, minimamente, o grau de complexidade apresentado nessa condição de vida. Nesse sentido são propostas terapêuticas a partir das relações de grupo que pretendem ampliar as possibilidades de inserção cotidiana no espaço familiar, institucional e social e que são deixadas de lado por ocasião das sucessivas crises e internações, como podemos constatar em matéria jornalística realizada com os profissionais e "usuários", publicada no jornal (local) Diário da Manhã em 09/03/2003.

Eles se sentem úteis e importantes ao chegar em casa e fazer um prato para o jantar que aprenderam na oficina. Isso é muito importante para a evolução do paciente.

A distribuição das tarefas também marca o próprio funcionamento do Caps [...] tudo é decidido em assembléia. Todos se comprometem e respeitam isso.

Nós damos apoio e suporte para os familiares [...] a familia que participa, permite que o paciente trabalhe normalmente e faça inúmeras atividades que contribuam imensamente para a recuperação [...].

Vale dizer que a concepção da psicologia tem gerado conhecimento que se constitui em avanço significativo na compreensão do mundo subjetivo daquele que sofre psiquicamente. No entanto, ainda registramos um forte alinhamento a saberes e práticas normalizadoras e perspectivas timidamente conectadas às complexas relações cotidianas que poderiam contribuir qualitativamente nos processos de subjetivação das pessoas em sofrimento. 


\subsection{Através da psiquiatria basagliana o encontro de outros lugares para a pessoa em sofrimento psíquico}

Estou de acordo que um esquizofrênico é um esquizofrênico, mas uma coisa é importante: ele é um homem que tem necessidade de afeto, de dinheiro, de trabalho; é um homem total e nós devemos responder não a sua esquizofrenia, mas ao seu ser social e politico.

(BASAGLIA, 1980)

A eficácia do modelo de atenção centrado na institucionalização já vinha sendo profundamente questionada tanto por profissionais, estudiosos da área e familiares, quanto por órgãos governamentais. As críticas apontavam para uma crise desse modelo que, além de não intervir na qualidade de saúde dos internos, era, segundo estes críticos, o produtor $\mathrm{e}$ mantenedor do adoecimento, responsável pelo alto indice de mortalidade $e$ cronificação dessas pessoas, gerando inúmeras incapacidades sociais (BIRMAN E COSTA, 1994).

Foi diante de semelhante conjuntura que Franco Basaglia pôs em evidência o contraste do discurso que privilegia a doença em detrimento do trabalho teórico-prático sobre a invenção da saúde, a produção de vida, sobre o "homem total", um ser que tem uma existência global e complexa, que não se resume aos sintomas nem às tipologias diagnósticas.

Assim, a partir da década de sessenta do século passado desenvolve-se na Itália, a psiquiatria de tradição basagliana, apoiada em algumas experiências de reforma ${ }^{51}$ e na aguçada crítica da antipsiquiatria ${ }^{52}$. Essa escola de pensamento sustentou o processo de reformas na psiquiatria

\footnotetext{
51 Entre elas, destaco as comunidades terapêuticas e a psiquiatria institucional, representando as reformas restritas ao âmbito asilar e a psiquiatria de setor que, juntamente com a psiquiatria preventiva (prevenção primária/saúde pública), representariam reformas para além do espaço asilar, envolvendo o âmbito comunitário. Essas reformas envolviam tanto a psiquiatria como a psicologia, a psicanálise e a saúde pública (Ver BIRMAN, J. e COSTA, J. F. Organização de Instituições para uma psiquiatria comunitária. In: AMARANTE, P (org). Psiquiatria Social e Reforma Psiquiátrica. Rio de Janeiro: Fiocruz, 1994, p. 41-72).

52 A antipsiquiatria foi um movimento que surgiu na década de 1960 , principalmente na Inglaterra, liderado por um grupo de psiquiatras, entre eles Ronald Laing e David Cooper que passaram a questionar de forma radical as relações entre a psiquiatria e a sociedade, considerando a loucura um fato fundamentalmente social e até mesmo uma experiência de libertação.
} 
nas cidades italianas e tornaram-se referência para muitas dessas experiências no Brasil e em outros países. Destaco os trabalhos do italiano Franco Rotelli et al. (1990), os de Paulo Amarante $(1995,1996)$ e de Denise Dias Barros (1994), brasileiros que também se debruçaram sobre a teoria basagliana e a psiquiatria democrática italiana.

A chamada "psiquiatria democrática italiana" foi um movimento capitaneado pela equipe de Basaglia em Gorizia e, mais tarde, em Trieste. Enquanto outros países pensavam a modernização do manicômio, a equipe italiana entendia-o como um lugar-zero de trocas sociais. Nos primeiros anos da década de 1960, um grupo de psiquiatras iniciou em Gorizia um trabalho de humanização do hospital, baseando-se, inicialmente, nos modelos da "comunidade terapêutica" e da "psicoterapia institucional". O seu objetivo era abandonar a violência como recurso e eliminar do cotidiano as práticas repressivas.

Os primeiros anos dessa tentativa foram suficientes para demonstrar seu caráter superficial, pois, embora tenha servido para democratizar as relações entre os atores institucionais, o modelo não passou de uma reformulação asilar. Foi através das obras de Foucault ( $A$ História da Loucura) e Goffman (Manicômios, prisões e conventos), inaugurando uma perspectiva crítica das instituições psiquiátricas que Basaglia aprofundou suas reflexões sobre a psiquiatria enquanto instrumento de saber e poder, de controle e segregação (AMARANTE, 1996).

A partir do encontro com a realidade do manicômio, intensificaramse as reflexões teóricas em "confronto" com o hospital psiquiátrico e com as experiências de comunidades terapêuticas e psiquiatria institucional. Para Basaglia, o chamado "manicômio" era uma experiência opressiva e trágica, um espaço rígido onde todas, ou quase todas as dimensões da vida eram controladas por uma autoridade e, portanto, precisavam ser confrontadas entre os componentes da comunidade no cotidiano.

A questão central do seu trabalho era o questionamento e a desconstrução do paradigma psiquiátrico clássico que havia transformado a 
loucura em doença, produzindo uma demanda social por tratamento e assistência, afastando o louco do espaço social e transformando a loucura num objeto abstrato sobre o qual construirá o seu saber. Dessa forma, a totalidade subjetiva e histórico-social entre o profissional e o objeto de seu trabalho ficava subtraída a um processo classificatório, instituído pelo saber médico que, justificado pela sua competência, era multiplicado no imaginário social (AMARANTE, 1995).

A experiência dos italianos orientou-se pela hipótese de que o mal da psiquiatria fora ter "separado um objeto fictício, a 'doença', da existência complexa e concreta dos pacientes e do corpo social. Sobre essa separação artificial construiu-se um conjunto de aparatos científicos, legislativos e administrativos (precisamente a instituição), todos referidos à doença" (ROTELLI et al., 1990, p.27) que, em última análise, serviam para dar-lhe sustentação. É daí que se origina a expressão "colocar entre parênteses a doença", invertendo o que a psiquiatria havia feito, "colocar o homem entre parênteses", ocupando-se da doença e tomando o sintoma como o próprio mal. Esta concepção não negou a existência de uma doença, mas procurou agir em um território não codificado ou definido a priori.

Foi um exercício de devolver ao sujeito doente a possibilidade de viver a sua condição de ser humano, passo fundamental para se aproximar da compreensão do sofrimento, dos efeitos da longa permanência na vida institucional e da construção de todos os conceitos que se constituíram em torno desse processo. A negação foi

[...] da instituição manicomial: da psiquiatria enquanto ciência; do doente como resultado de uma experiência incompreensivel, do papel de poder puro do psiquiatra em relação ao paciente; do seu mandato social, exclusivamente de custodia; do papel regressivo do doente, colocado junto à cultura da doença; a negação e a denúncia da violência à qual o doente é sujeito dentro e fora da instituição [...] (BASAGLIA et. al, 1994, p.16).

Situando a mesma problemática, Denise Barros $(1994$, p.38) traz importante contribuição, ao discutir o fundamento de periculosidade social contido no saber psiquiátrico, portanto, focalizando a loucura como 
periculosidade. O encontro entre os aparatos da administração pública e da justiça, e os aparatos da ciência e da medicina transformou esse conceito no principal atributo da loucura, quer seja por parte do Estado (construção de manicômios, legislações), quer seja por parte da psiquiatria (justificativa de internação, pesquisas científicas sobre causas e métodos), ou, ainda, por parte da justiça (escolha do direito positivo, imputabilidade e inimputabilidade, necessidades de defesa social, desenvolvimento das medidas de segurança).

Assim, o processo italiano representou um movimento de desconstrução (desinstitucionalização) desse conjunto, para concentrar esforços no campo social, no sentido de uma invenção permanente que assumisse a complexidade da existência-sofrimento dos sujeitos, colocando em evidência o sujeito que sofre e suas condições de reprodução social. Para tanto, um dos eixos trabalhados foi a transformação das relações de poder entre instituições e sujeitos, passando por ações do cotidiano que estivessem voltadas para a reconstituição das pessoas doentes enquanto sujeitos de desejos, de necessidades, de valores. Nessa direção, as estratégias são tanto mais ricas quanto mais diversificadas forem. Nelas não se anula o sofrimento, mas, conforme elucida Rotelli et al. (1990), mudam-se as formas e o peso que este impõe ao jogo da vida, cuidando do sujeito sofredor nas mais sofisticadas dimensões de sua existência. Isso implica, também, que se coloque o problema da loucura no âmbito da cidade como forma de propor à sociedade a confrontação com esta e com outras formas de exclusão que promove em todo o tecido social.

Por isso, essa perspectiva propôs que os seus operadores (trabalhadores de saúde mental), através de uma constante exigência ética, mediassem esse trabalho gigantesco, polêmico, contraditório, ativando a rede de relações que se estrutura no campo social, investindo, envolvendo e mobilizando famílias, pacientes, comunidade local e sujeitos institucionais como atores dessas mudanças, redesenhando novas formas de integração social, criando outras oportunidades e alargando os espaços de liberdade dessas pessoas (ROTELLI et al., 1990). 
Foi nesse percurso que se fechou o hospital psiquiátrico ${ }^{53}$. Se a institucionalização vivida até então encobria o "homem total" como mencionado na frase epigrafada desse capitulo, esse processo de apropriação de si, da sua condição no espaço da cidade abria um leque de maior complexidade. Os itinerários terapêuticos, antes reduzidos à institucionalização, foram se constituindo na complexidade gerada pelas necessidades de um sujeito que saía do espaço institucional com uma lógica própria, para viver nos espaços abertos da cidade com um conjunto de novas interações que, vale dizer, eram novas tanto para ele como para os demais moradores que passavam a conviver com essa realidade. Alves e Souza (1999, p.125) afirmam que os itinerários terapêuticos são "os processos pelos quais os individuos ou grupos sociais escolhem, avaliam e aderem (ou não) a determinadas formas de tratamento". São traçados ao longo da história do adoecimento e são, profundamente, influenciados pelo contexto sócio cultural. Esse conceito dá a dimensão da complexidade a que me refiro, pois, de um lado, já existe um imaginário social sobre esse sujeito, que precisa ser desconstruido, por outro, existe uma biografia afetada pela doença e pela institucionalização que também precisa ser reconstituida. É desses enlaces no campo social que se constituem os itinerários, incorporando as contradições, os medos, as possibilidades, e, recriando espaços relacionais que possibilitem abertura para "outros mundos".

Em conferências e debates realizados no Brasil, ao final da década de 1970 , Basaglia argumentava que a proposta italiana não via a loucura apenas como produto do social; se assim o fizesse seguiria a mesma lógica positivista de considerá-la produto do biológico ou orgânico, ou do psicológico. Para ele,

[...] a loucura como todas a doenças são expressões do orgânico e do social. É nesse sentido que direi que a doença, sendo uma condição que se verifica no ambiente social, não é um produto apenas de uma sociedade, mas uma interação dos niveis dos

\footnotetext{
${ }^{53}$ O parlamento italiano sancionou em 1978 a Lei de $n^{\circ} 180$ que proibiu a construção de novos hospitais e de novas internações psiquiátricas. Determinou o esvaziamento gradual dos hospitais psiquiátricos existentes, constituiu a criação de serviços territoriais que passaram a ser responsáveis pela assistência e aboliu o estatuto de periculosidade social do doente mental e da tutela jurídica (BARROS, 1994).
} 
quais nos compomos: biológico, psicológico, sociológico... Dessa interação participa uma quantidade enorme de fatores [...] eu acho que a doença em geral é produto histórico-social. Algo que se verifica nessa sociedade em que vivemos, em que há uma história e uma razão de ser. (BASAGLIA, 1980, p.79 - grifo nosso).

Basaglia (1980) prossegue em sua argumentação, afirmando que a loucura é uma condição humana e, como tal, requer também a reconstrução de sua complexidade no território (geográfico e da realidade existencial) onde a vida acontece. ROTELLI et al. (1990, p.30) expressam bem esse pensamento, ao enfatizarem o projeto de "invenção de saúde" e de "reprodução social" do sujeito que sofre, ao invés do processo de "cura", ou melhor, de normalização, enfatizado na psiquiatria tradicional, "Se não existe mais um mundo produtivo definido no qual estar, não existe mais uma saúde, mas existe mil. [...] O problema não é a cura (vida produtiva), mas a produção de vida, de sentido, de sociabilidade, a utilização das formas (dos espaços coletivos) de convivência dispersa" (grifo nosso).

Diante disso, vale explicitar que a idéia que me une a Basaglia é essa "renúncia" a um olhar pouco facetado, preconceituoso, mórbido e destituído de sentido para quem vive essa condição humana. Instiga-me o seu convite para entendermos que estamos diante de um sujeito co-participante de um sistema de crenças e desejos e que essas experiências não são uma construção individual, mas resultado de um diálogo com a cultura e com as diferentes conexões que atravessam o mundo contemporâneo. Assim também se justifica que nenhuma disciplina pode atribuir a si própria a ousadia de dar conta de um campo tão complexo como este.

\subsection{A dimensão antropológica da saúde-doença}

Em minhas incursões pelo campo de pesquisa, percebi que tanto os protagonistas quanto os narradores têm conceitos próprios sobre 0 sofrimento psiquico e ressignificam esses conceitos a partir do seu lugar, dos seus sistemas simbólicos, de sua cultura. A experiência dessa situação de vida é constituida de múltiplos sentidos que são, ora antagônicos ora 
complementares, colocando as pessoas diante de várias possibilidades de compreensão bem como de maneiras distintas de superação do sofrimento.

Embora uma das características detectadas no universo desta pesquisa seja a forte proximidade com os saberes "psi" e suas intervenções na concepção do sofrimento psíquico, outras percepções aparecem concomitantemente, como por exemplo, o contato freqüente com crenças ou explicações religiosas, tornando os itinerários terapêuticos mais amplos e diversificados. Essa contigüidade tanto pode ser entendida como enriquecedora e desejável, como restritiva e, por vezes, preconceituosa. Se observarmos o discurso de alguns profissionais de saúde, encontraremos, com freqüência, essa perspectiva preconceituosa, marcada, inclusive, pelo uso de determinadas palavras. Assim, os "usuários" são tomados por "ignorantes", pessoas a quem falta "cultura", porque procuram outras formas de resolver os seus problemas de saúde. Os lugares que ocupamos e de onde enunciamos nossas proposições, por vezes, colocam o saber legitimado pela ciência (profissional) como "absoluto", levando à desvalorização de determinados sistemas simbólicos e de determinadas práticas, muitas vezes, tidas como "inimigos" a serem combatidos, demonstrando o quanto carecemos de compreensão da cultura do outro a quem pretendemos tratar. Isso nos remete a uma questão: se do ponto de vista das práticas tradicionais de saúde esse conjunto de outros significados e práticas não respondem às questões de sofrimento, porque as pessoas continuam recorrendo a elas?

A antropologia, ao privilegiar o estudo das distintas manifestações culturais relevantes aos diferentes modos de vida, traz o ingrediente da ressignificação que os diversos fenômenos e, neste caso, o da saúde e da doença, tomam em cada cultura, a partir de seus sistemas simbólicos. As distintas manifestações dizem respeito a uma multiplicidade de vozes presentes na constituição dos diferentes fenômenos e do diálogo entre elas. Essa multiplicidade refere-se aos significados partilhados nas redes de relações, às experiências individuais que abrangem tanto os significados simbólicos particulares do sofrimento em si, quanto os significados criados 
pela pessoa para poder lidar com essa experiência. Tais questões estão também associadas a concepções e expectativas de gênero, trabalho, classe social, entre tantas outras.

Duarte faz uma análise das leituras antropológicas no campo da chamada antropologia da saúde $e^{54}$ e destaca a inseparabilidade do horizonte integrado de cada cultura em relação à situação do adoecimento, buscando, dessa forma, o sempre necessário relativismo. Considera que a contextualização da "doença" no interior de uma problemática nomeada como da "pessoa" e do "corpo" (como construção social da pessoa) pode se constituir em elo estratégico útil para reentranhar, reintegrar na totalidade da experiência social um conjunto de categorias, representações, práticas e instituições [...] (1998, p.12).

O autor afirma também que a antropologia da saúde sofreu os mesmos reveses que constrangeram as experiências de saúde e doença nas demais disciplinas, entre os quais, a medicalização e a naturalização decorrentes da racionalização, o afastamento do sensivel, a psicologização dos sujeitos associada à auto-responsabilização pela ocorrência de suas perturbações.

Como referência nos estudos dessa natureza, tomamos o clássico trabalho de Duarte, "Da vida nervosa da classe trabalhadora", como um dos exemplos onde a categoria em estudo das classes populares - o "nervoso" não se comporta segundo o modelo individualista dominante na sociedade contemporânea. Expressões semanticamente mais abrangentes da doença, como o sofrimento e as perturbações, podem indicar sentidos, por vezes mais amplos do que os sentidos biodeterministas, e compreender essas

\footnotetext{
${ }^{54} \mathrm{Na}$ Antropologia da Saúde destaco alguns trabalhos que fazem referência ao sofrimento psiquico Entre eles: DUARTE (1986) acima citado; RABELO; ALVES; SOUZA (1999), sobre a experiência da doença e narrativas sobre as doenças mentais, realizado no nordeste de Amaralinas/Ba; SILVEIRA (2000) sobre o "nervoso" entre as mulheres de Campeche/SC e CAROSO; RODRIGUES e ALMEIDA FILHO (1998) sobre o manejo comunitário em saúde mental também na Bahia. Outros estudos que merecem destaque e que entendo, fazem uma interface importante entre a saúde e a antropologia são os realizados por ROCHA (2000) referente as Trajetórias terapêuticas de "usuário"s de serviços psiquiátricos e adeptos da umbanda: um estudo sobre o pluralismo terapêutico e por REINALDO (2003) intitulada Conhecendo o itinerário Terapêutico em saúde mental pela história oral de vida do paciente psiquiátrico, EEUSP/Ribeirão Preto.
} 
experiências nas dimensões de vida. Foi o que fez o autor, ao eleger o "nervoso" como um nódulo ideológico estratégico para a compreensão das formas culturais específicas que constituíam um segmento de trabalhadores expostos ao processo de urbanização:

Foi nesse sentido, por exemplo, que defendi a adoção da
categoria "perturbações físico-morais para designar
congregadamente a area dos fenômenos humanos que nossa
cultura individualista segmenta em "doença dos nervos",
"possessão", "transe", "distúrbio psiquico", "psychosocial
distress", "somatização", etc. O qualitativo "físico-moral"
procurava ai justamente reconstituir o caráter de vínculo ou
mediação de que esses fenômenos se cercavam na relação entre
a corporalidade e todas as demais dimensões da vida social
(inclusive a espiritual ou transcendental, eventualmente)
(DUARTE, 1998, p.24).

É preciso estarmos atentos aos processos que fazem a mediação entre as explicações e a forma de lidar com o sofrimento, em contextos especificos, para que possamos compreender a complexa dinâmica de relações (interações) que compõem esse quadro, tanto do ponto de vista dos fatos associados ao seu desencadeamento e sua representação para o mundo da pessoa, quanto do conjunto de redes sociais e de equipamentos de tratamento que se constroem e são acionados nessas circunstâncias.

\section{a) Religiosidade e sofrimento psíquico}

Para ilustrar como o sofrimento é representado a partir de diferentes compreensões, utilizarei o exemplo da religiosidade pela importância que alcançou no campo da pesquisa. Diferentes agências religiosas são acionadas e transformadas em imagens e práticas que possibilitam interpretações sobre as causas e rituais de tratamento da pessoa que vivencia a experiência do sofrimento psíquico.

Sabiá e sua familia ressignificam sua experiência a partir da religião, mesmo tendo passado por várias internações e seguido a terapia medicamentosa do sistema oficial de saúde. No momento em que esteve "fora-de-si" a familia providenciou ajuda: 
Foram chamar o pastor da igreja pra vir aqui e ele me disse que não tinha bicho morto e fez oração, mas eu não conseguia sossegar. Eu não conseguia ficar na cama, dormir, nada. Sentia uma irritação das músicas que não eram da igreja. A "coisa ruim" - do capeta -, me atentava.

Da última vez eu lia muito a bíblia. Tenho um irmão que é da Assembléia de Deus e eu queria entender como ele, mas eu me confundia, não sabia discernir. De repente eu era o personagem da biblia. Eu não sei o que é isso, se é doença ou se é Saravá porque parece que eu quero aceitar Jesus e o inimigo me atenta. Eu aceito Jesus, mas não me firmo na lgreja. Por exemplo, eu gosto de escutar música e ele (seu irmão) só escuta hino, não pode escutar outras músicas.

As indicações de que a vida estava tão "normal" como antes do adoecimento eram explicitadas por Sabiá com a seguinte expressão: a coisa ruim não me atentou mais! No entanto, as entidades religiosas da igreja que sua família freqüenta apontam uma fragilidade em sua vida que precisa "de constante vigília e correntes de orações" para que tenha a proteção divina e não "seja mais atacado pelas forças do mal".

Situação semelhante é vivida por João-de-Barro que também recorre a práticas religiosas para fortalecer sua saúde. Ele não deixa de ir à igreja nenhum domingo, conforme relata sua mãe:

Eu vou à missa com ele, nem que seja de arrasto (referindo-se às suas eventuais dificuldades de caminhar). Era melhor quando tinha o padre João porque ele já sabia do problema dele e, antes ou depois da missa chamava nós na salinha e dava a benção. Sempre falava umas palavras de força pra nós passar aquela semana. Quando o João-de-Barro ficava internado ele rezava na missa pra que ele ficasse bom logo. Graças a Deus e aos médicos ele continua conosco.

Lurdes, uma das depoentes da fase inicial do estudo, identifica com detalhes as marcas do que lhe aconteceu, registrando as "perturbações" que foram desorganizando a sua lógica de operar num determinado momento:

O que marcou mais a minha situação é que eu não fazia nada direito. Eu não conseguia parar dentro de casa. Parece que tinha uma coisa que me puxava pra fora. Nunca tinha tido problemas com ninguém e, de repente, comecei a me desentender com as vizinhas, diz que eu xingava. [...] As minhas irmãs dizem que eu chegava na casa delas, abria a geladeira, comia, dizia que as comidas estavam ruins, falava, chorava, mas eu não me lembro disso tudo. Eu não conseguia ficar nos encontros, tipo no fim de semana quando a familia se encontrava. Aquela reunião, as 
conversas, discussões me faziam mal, eu tinha que sair, vir embora. Às vezes eu pegava a minha pequena (filha) e vinha pra casa.

Eu comecei a freqüentar uma Igreja Universal. Lá eu não sei o que acontecia, eu chorava, gritava era alguma coisa que me derrubava. Depois me disseram que eu incorporava e eles não sabiam me tirar.

Ana, mãe de Lurdes, comentando sobre a procura por terapêuticas diz:

No hospital psiquiátrico ela estava intranqüila. Sentamos num banco lá no lado e ela começou a me dizer que não tinha dormido a noite toda porque tinha duas mulheres que passaram o tempo inteiro rodeando na volta da cama. De repente ela começou a gritar, caiu, travou as pernas, foi um horror. Ai levaram pro quarto, foi um monte de gente pra segurar, fazer injeção. Eu fiquei acompanhando e ela me pedia, por favor, pra tirá-la de lá. Aí conversamos com o pai de Santo e ele explicou tudo direitinho o que estava acontecendo com ela... Ela tinha encarnado... tiramos ela do hospital e ele veio pra passar o serviço. Foi bem dificil, lutou muito, mas conseguiu.

A família de Lurdes que já é iniciada na umbanda está convencida de que o que ocorreu com ela foram sinais de perturbação de uma rede de relações pessoais e espirituais expressas em seu comportamento. $O$ fato foi corroborado pelo desaparecimento dos "sintomas" após a realização de determinados rituais no Centro Espírita, possibilitando a retomada da capacidade de trabalho de Lurdes e a volta às suas atividades cotidianas.

Uma marca dessas experiências é o seu caráter coletivo, através da invocação para que o sujeito em sofrimento, seus familiares e comunidade religiosa participem ativamente dos rituais.

Caroso et al. (1998), analisando os discursos que envolvem o itinerário terapêutico dos doentes mentais observaram que, contrariamente aos tratamentos psiquiátricos mais tradicionais, os tratamentos comunitárioreligiosos podem resultar na atenuação do estigma ou mesmo, na rotulação positiva da pessoa. O caso de Lurdes é ilustrativo dessa positividade, colocando-a num lugar de valor - "aí descobrimos que ela tinha muita mediunidade" -, o que requereu um tratamento envolvendo, profundamente, 
todos os membros da família, já que era a rede de relações que estava comprometida.

Embora nenhuma concepção teórica seja capaz, isoladamente, de dar conta dessa empreitada, a via antropológica tem um potencial imenso a ser explorado, enriquecendo as possibilidades de lidar com o sofrimento que é uma construção de todos os que constituem o campo, cada qual participando com sua visão. Nesse particular, os serviços de saúde do sistema oficial constituem-se como uma das possibilidades terapêuticas, juntamente com outras agências, instituições e redes sociais da própria comunidade que compõem diferentes estratégias de tratamento, proteção e acolhimento.

\subsection{A complexidade do 'problema mental': uma trama que liga e religa}

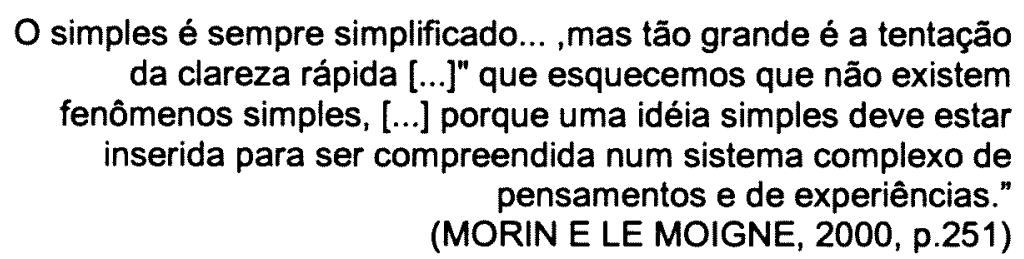

Penso que não percebi, quando iniciei a pesquisa, a complexidade da empreitada que assumia. A própria categoria que queria pesquisar era, e talvez continue sendo, um emaranhado difícil de ser explicitado, pelas suas múltiplas facetas e pelas contradições também flagradas em e por mim oriundas de um pensamento disciplinar compartimentado. À medida que desenvolvia o trabalho, o meu objeto tornava-se mais e mais complexo, colocando uma multiplicidade de dinâmicas que se conectavam com diversas dimensões da vida, embora o envolvimento em torno da "doença", balizasse muitas dessas conexões.

Há uma dinâmica que se estabelece no processo das relações e em seus desdobramentos para a qual senti-me desafiada a olhar - ainda que de forma limitada -, no sentido de compreender os mais diversos aspectos que configuram a vida cotidiana e que nos mostram sujeitos singulares nos seus 
contextos. "Cada um representa vários papéis sociais, segundo o que é na sua casa, no seu trabalho, com amigos ou com desconhecidos. Vê-se que cada ser tem uma multiplicidade de identidades, uma multiplicidade de personalidades nele próprio, um mundo de fantasmas e sonhos que acompanham a vida" (MORIN, 1990, p.83-4).

Para tanto, recorro a Morin (2000) com vistas a estabelecer um diálogo com o problema. Ao propor o "pensamento complexo", o autor opõese à forma reducionista e determinista de interpretar a realidade dominante através dos tempos o que provocou disjunção e redução na construção do pensamento, separando o sujeito do objeto, a alma do corpo, o sentimento da razão, a existência da essência. Esse modo de pensar construiu-se sob a perspectiva de que o real é universal e que a realidade poderia ser compreendida através de argumentos racionais e objetivos. Tal pensamento gerou um conhecimento especializado, fragmentado e parcelado, provocando uma grande incapacidade de promover a re-ligação do sujeito com o universo que o rodeia. Este é um pensamento consoante com 0 ocorrido no campo da saúde mental, como discuti anteriormente.

O autor afirma que o problema "não é reduzir nem separar, mas diferenciar e juntar". O problema chave é de um pensamento que una, por isso a palavra "complexidade" do pensamento, chamando a agregar aos pilares do pensamento científico (ordem, separatibilidade e razão) um pensamento que comporte em seu interior um principio de incompletude, de incerteza, de sensibilidade. Nesse sentido, há que se considerar a necessidade de ver os diferentes aspectos de um mesmo fenômeno, entendendo que o ser humano, enquanto integrante do cosmos, está interligado a um emaranhado de relações que não podem ser tratadas isoladamente uma vez que se nutrem mutuamente.

Morin elencou três princípios indissociáveis para pensar a complexidade: o hologramático, o recursivo e o dialógico. Pautou-se pela busca da contextualização, do sentido de uma totalidade hologramática, mostrando que não podemos considerar apenas as partes sem olhar o todo, 
nem apenas o todo sem termos em conta as partes. Da mesma forma que cada célula carrega o material genético do todo de um indivíduo, cada um de nós é uma parte da sociedade e também a "carrega" consigo, através da sua cultura, da sua linguagem, das suas normas.

Desse modo, afirma ainda que "a sociedade é produzida pelas interações entre os individuos, mas, uma vez produzida, retroage sobre os indivíduos e os produz" na lógica da recursão ou da circularidade, como uma espiral, um remoinho, negando a cadeia linear causa-efeito, produtorproduto (MORIN, 1990, p.108). Portanto, somos o produto de um processo que é anterior a nós e tornamo-nos produtores do processo que vai continuar, ou seja, pensando nas relações interpessoais, elas são constituídas e constitutivas nesse meio sócio-histórico-cultural. Esse pensamento também possibilita o entendimento de que, nessa interação, a pessoa em sofrimento psíquico sofre fortes influências do campo social, por questões "instituidas" e que, ao mesmo tempo, retroage sobre essas determinações, imprimindo-Ihes singularidades.

O ser é, ao mesmo tempo, múltiplo em sua unidade, o que o torna diferente quando está invadido, por exemplo, por um delírio que pode fazê-lo tomar decisões absolutamente distantes e antagônicas às convencionais, mas necessárias e possiveis para suportar aquela situação. No campo familiar, semelhante idéia da circularidade já foi desenvolvida por alguns autores, entre os quais o psicólogo argentino Pichon Riviére (1988) que faz referência à família como um todo. Para ele, o lugar que coube ao sujeito que adoeceu foi o de depositário de ansiedades, de medos, de um sofrimento incontido que não pode ser traduzido e elaborado nas gerações que o antecederam. Aqui, a pessoa é "invadida" pela falta de opção desse núcleo familiar que não pretendeu, conscientemente, elegê-la para ser o bode expiatório, mas foi estabelecendo uma dinâmica que acabou por deixála quase sem lugar, com quase nada do que seria propriamente seu. Assim, a função exercida pelo membro que adoece no núcleo familiar é vital para manter os demais "aliviados". 
À medida que esses papéis não são "trabalhados" no seu conjunto, a tendência é continuar elegendo alguém para depositar a multiplicidade de fatores não suportados, conduzindo a novos deslocamentos que repicam nos outros e alteram novamente as regras e a dinâmica do "jogo".

Dessa forma, pensar o fora-de-si com base numa construção individual ou individualista do mundo não oferece meios para ultrapassar os valores da norma, da simplificação de um processo que se constituiu de um emaranhado complexo que se entrecruza e se entrelaça, "[...] é perder a riqueza dos elementos que se entrecruzam e se entrelaçam para formar a unidade da complexidade de um sujeito que vive uma condição humana, destruindo a variedade das complexidades que o teceram" (MORIN, 1998, p.188).

Esse pensamento também desafia a unir/integrar de modo complementar questões antagônicas - consenso/conflito, lógica/estranhamento, inclusão/exclusão, autonomias/dependência, ordem/desordens..., - mostrando que são indissociáveis e indispensáveis para a compreensão da realidade, como um jogo incessante e incerto com múltiplas lógicas: um caráter dialógico (MORIN; LE MOIGNE, 2000, p.204), Se pensarmos duas maneiras dos serviços de saúde abordarem o sujeito com sofrimento mental, a manicomial (fechada) e a comunitária (aberta) podemos ter um exemplo de relação dialógica, inclusive podemos encontrálas na mesma instituição. De outro modo, a partir do campo de pesquisa, percebemos que diferentes práticas terapêuticas são freqüentemente acionadas pelos familiares, compondo um conjunto de recursos também de caráter dialógico.

Assim, essa forma de pensamento está apta "a reunir, contextualizar, globalizar, mas ao mesmo tempo reconhecer o singular, o individual, o concreto" (MORIN; LE MOIGNE, 2000, p.213), permitindo a construção de uma complexa teia de relações. Os movimentos na vida cotidiana dão-se através dessas redes entre os diversos sistemas sociais, em diferentes domínios de conversação que, apesar de independentes, 
afetam-se mutuamente. Há assim, uma re-ligação entre os elementos que dão sentido àquilo que Morim chama de complexus, entendendo por esse fenômeno aquilo que se "tece junto". Pensar a complexidade neste trabalho, é pensar num tecido (relações interpessoais) em que os fios paralelos não são apenas presos com amarras, confundindo-se, mas ligados transversalmente por uma trama (dinâmica das relações) que os liga e religa, movimentando novamente todos os fios e construindo uma outra textura, uma outra estampa (novas dinâmicas, novas relações). Dessa forma, entender a realidade significa percebê-la em suas múltiplas interações e composições construídas no dia-a-dia, nas ações e situações concretas do cotidiano.

Embora vivamos as incessantes tentativas de eliminar as incertezas, o indeterminado, o impreciso, somos por eles surpreendidos, como é o caso do adoecimento psíquico (que pode ser considerado um ruído nos termos de Morin) e por tantos outros que acompanham o cotidiano. Nesse sentido, existe a necessidade de negociações (com essas incertezas) na perspectiva de construir pontes, mesmo que provisórias que permitam um ir e vir, reconstruindo no cotidiano novas formas de lidar com a vida sem que essas situações se constituam, necessariamente, numa fatalidade como as frases recorrentes sobre os nossos interlocutores pesquisados: coitado, endoidou! Não tem cura!

Diante dessas circunstâncias, o pensamento cunhado por Morin possibilitou uma melhor apreensão desse complexus, contribuindo para compreendermos essas pontes que constituem as interaçōes vividas e que compõem trajetórias, por vezes, tão abafadas, ocultas e desprezadas, particularmente do lugar de onde me via posicionada (de fora). A circulação no espaço da cidade da qual, historicamente, se procurou excluir o doente mental, trouxe a riqueza de poder entender o que ficou mais afastado das estruturas psiquatrizantes ou escapou da produção serializada do nosso fazer profissional, também impregnado na malha social. É na dinamicidade desse ser em relação, nos seus 
movimentos, na sua fluidez que percebemos o processo de ordem, desordem e reorganização e a busca de sentidos através de novas tramas, de novas texturas, de novas crises, de novas rupturas..., de novas ligações. 


\section{CAPÍTULO IV - CARTOGRAFIAS DO COTIDIANO}

...tais cartografias têm em comum a busca de saídas na
constituição de outros territórios, para além dos territórios sem
saídas, outros espaços de vida e de afeto. São elas todas obras
de tais inconscientes que, atrevidos, "protestam"

(ROLNIK, 2000, p. 14)

\subsection{Da cartografia oficial à cartografia do bairro: o ponto de vista dos} seus moradores

Utilizarei a palavra cartografia para caracterizar os distintos mapeamentos delineados no decorrer do trabalho. Como já disse anteriormente, meu ponto de partida foi um mapeamento oficial a partir do qual fui ampliando os contatos, a fim de captar quem eram os reconhecidos no cotidiano do bairro como "doentes mentais". Posteriormente, mapeei os percursos percorridos por esses sujeitos que, em função dessa condição, vão produzindo distintos caminhos constituídos de determinadas redes (sociais, afetivas, de serviços de saúde): novas cartografias.

Nesses termos, a cartografia é entendida para além do mapeamento de um território geográfico estático. É um desenho que acompanha as mudanças e os sentidos produzidos por determinada situação de vida nos territórios, que são também psicossociais. Sendo assim, a cartografia busca captar os universos traçados pelos modos de vida, pelo desejo, pelos 'desmanchamentos' de certos mundos que vão se tomando obsoletos, ou que fogem das suas possibilidades concretas pela situação vivida, pela desterritorialização ${ }^{55}$ e que correspondem a diferentes formas de inserção social e cultural.

\footnotetext{
${ }^{55}$ Nos termos de Guattari e Rolnik (2000, p.323), esse território que pode ser um conjunto de projetos e das representações nos quais vão desembocar, pragmaticamente, toda uma série de comportamentos, de investimentos, nos tempos e nos espaços sociais, culturais, estéticos, cognitivos, pode se desterritorializar, isto é, abrir-se, engajar-se em linhas de fuga e até sair de seu curso e se destruir. A espécie humana está mergulhada num imenso movimento de desterritorialização, no sentido de que seus territórios "originais" se desfazem ininterruptamente com a divisão social do trabalho, com a ação dos deuses universais que ultrapassam os quadros da tribo e da etnia, com os sistemas maquínicos que a levam a atravessar cada vez mais rapidamente, as estratificações materiais e mentais. A reterritorializaçâo constituirá a tentativa de recomposição de um território engajado de um
} 
Com as informaçōes do mapeamento oficial foi possivel uma aproximação mais completa das características desses moradores. De modo geral, têm menos de 40 anos de idade, estão distribuídos eqüitativamente entre homens e mulheres e localizados, espacialmente, por todo o bairro. Esse mapa trazia um total de 46 pessoas cadastradas.

Percebi que existia uma "circulação" importante dessas pessoas em relação ao local de moradia. Algumas vezes, essa circulação se dava pelas casas dos parentes, outras, pela mudança da própria família. Mas, com a aproximação e a freqüente resposta: "aqui por perto não tem ninguém com esses problemas", entendi que os nossos sistemas classificatórios também se diferenciavam em alguns aspectos.

Ao tentar estabelecer uma comparação entre os dados do bairro e o mapa oficial, percebi que os dados não eram coincidentes, isto é, percebi que as pessoas constantes do mapa como sofredoras psíquicas não eram reconhecidas como tal pelos moradores. Num primeiro momento, a sensação era a de que o mapa (elaborado a partir dos serviços de saúde com ênfase em dados dos usuários colhidos nos processos de internação) não me indicaria acessos confiáveis de aproximação com os sofredores psíquicos. Mas fui percebendo, no decorrer do trabalho, que além dos moradores não considerarem "doentes mentais" o que o mapa assim registrava, como é o caso dos depressivos e dependentes químicos, o próprio roteiro oficial merecia uma atenção especial. Em outras palavras, parece-me que o hospital havia alargado sua clientela, passando a internar pessoas cuja história não justificava a referida internação ${ }^{56}$. É claro que a história do paciente não justificava a internação, do meu ponto de vista, das

processo desterritorializante. Esse trinômio: Territorialização-DesterritorializaçãoReterritorialização está sempre se refletindo no cotidiano dos sujeitos. Dessa forma, a desterritorializacão é um movimento de desmanchamento de um território psicossocial, quando este deixa de ser operador dos afetos vividos na atualidade de sua existência.

${ }^{56}$ Pela legislação vigente, especialmente a Lei 10.216 de 6 de abril de 2001 e a Portaria $n^{\circ}$ $2.391 / G M$ de 26 de dezembro de 2002, a internação psiquiátrica, em qualquer de suas modalidades, só deverá ocorrer após todas as tentativas de utilização das demais possibilidades terapêuticas e esgotados todos os recursos extra-hospitalares disponiveis na rede assistencial. 
minhas construções sobre a internação psiquiátrica e, também, daquilo que o imaginário do bairro caracteriza como doente mental.

Assim, observei que o recurso da internação tem particularidades no sentido de que há uma tendência à exacerbação do quadro da pessoa doente que nem sempre está em crise. São particularidades relativas, principalmente, às condições da internação que na maioria das vezes ocorre sem o consentimento dessa pessoa. Esse aspecto, que normalmente gera forte resistência à pessoa em sofrimento psíquico, é também um dos principais fatores de agitação e violência durante a admissão hospitalar. Por sua vez, essa condição é a prioridade estabelecida pelo hospital para a internação ${ }^{57}$. Corrobora esta situação o registro da história do internado contada pelo acompanhante, que normalmente conhece os códigos de acesso à internação e faz uso deles com a finalidade de que esse procedimento, de fato, ocorra. Nesse particular, a pessoa em sofrimento tem pouco a acrescentar. Aliás, o que ela disser poderá ser interpretado como mais um motivo de desconexão da realidade e de reafirmação do suposto risco. Esse processo impõe "marcas institucionais" na pessoa que vive essa experiência e produz um achatamento de outros aspectos da vida, constituindo para o sujeito um momento bastante diferente da situação cotidiana, no qual as pessoas não estão submetidas à "captura" pelo campo psi.

Passados mais de trinta anos da proposição de Basaglia de colocar a doença entre parênteses, por ter constatado que a institucionalização produzia um "duplo", ou seja, que existia uma face institucional da doença mental construida a partir de uma negação e de uma objetivação extrema da pessoa, percebo que esse processo está vivo e impregnado na micropolítica local. Por outro lado, a casa e a rua permitem outras expressões não perceptiveis, ou pouco perceptiveis no cotidiano das instituições. No cenário do bairro, essas pessoas também são trabalhadoras, cuidam da casa, dos

\footnotetext{
${ }^{57}$ Como já referido anteriormente o processo de triagem é "priorizado o atendimento de quadros agudos com risco de agressão e lou suicídio" (Projeto Terapêutico do HPBM/PF, 2003).
} 
filhos, exercem papéis bastante distintos, usam roupas comuns e, às vezes, buscam o serviço de saúde.

Inspirada em Rolnik (1989) entendo que as instituições de saúde mental, em nome de uma função social, capturariam esses sujeitos, no sentido de estancar/impedir a possibilidade dos fluxos desejantes produzidos por eles e, na maioria das vezes, expressos em grande intensidade na situação patológica. Esse processo desconsidera e artificializa os diferentes territórios existenciais desses sujeitos (relacionados a questões internas e externas, relações familiares, sociais) que, nessa lógica da doença, são reduzidos a um comportamento destrutivo, sem sentido, que deve ser apagado, diminuindo as chances de reabilitação e gerando novos problemas, quais sejam: desvitalizam o sujeito, aumentam a segregação, a exclusão social - que se assemelha à face institucional da doença descrita por Basaglia. Há nessa relação, um distanciamento entre o que é "supostamente tratado" e os elementos que produzem sentido para o sujeito e que lhes permitem criar possibilidades de vida não doente.

A captura de algo que produz sentido para a pessoa expressa a "artificialidade" das relações que se estabelecem entre profissionais e usuários, e pode ser percebida em pequenos atos cotidianos que tive a oportunidade de observar e registrar, durante o periodo da pesquisa:

Um funcionário de uma instituição de saúde, vendo-me conversar com um dos protagonistas desse estudo, advertiu-me de que se tratava de um sujeito altamente "periculoso". Pediu que ficasse atenta, pois ele já manifestara 'agressividade' muitas vezes, a ponto, até mesmo, de ter causado danos ao espaço físico da instituição. Suas longas passagens por hospitais psiquiátricos nos últimos tempos, eram marcadas por "contenções" químicas com altas doses de medicamentos ou, contenções mecânicas no leito que, na linguagem dos internos, significa: ficar nas cordas. Contraponho a essa situação explicitada pelo trabalhador de saúde, a imagem de um pai extremamente dedicado e carinhoso, brincando na praça com seu filho de quatro anos, num domingo de manhã. João-de-Barro faz isso regularmente, aos finais de semana, com o filho que mora com a ex-mulher em um bairro bastante distante do seu. Levanta cedo, toma o primeiro ônibus e vai buscar o menino, preparando "agradinhos" como: passear na praça, preparar uma comidinha especial, ir à igreja com a mãe e o filho, enfim, dedica o dia para celebrar seu papel de pai. No horário combinado faz o caminho de volta, tomando todos os cuidados de uma pessoa responsável: segura pela mão, dá-lhe 
colo, alimento, limpa, acomoda para dormir enquanto o ônibus não chega,... Observo, no decorrer da pesquisa, seu trânsito no bairro, sua relação amistosa com a vizinhança, sua ida ao mercado e ao banco.

Sempre que encontro dona Jussara, no Caps ou em outro lugar, ela se diz "muito mal". Apesar dessa imagem, tive a oportunidade de presenciar os seus préstimos aos amigos, quando os benze para proporcionar-Ihes conforto físico e/ou espiritual. Sua comadre pediu que ela benzesse o marido, que 'sentia dores nas 'cadeiras', observando que dona Jussara 'tem uma mão abençoada'. Esses imponderáveis do cotidiano fizeram-me perceber o quanto nós, profissionais da saúde, deixamos de apreender das múltiplas dimensões de vida das pessoas que buscam ajuda no sistema (de saúde) porque o nosso conhecimento estabelece, muitas vezes, um canal limitado, um comportamento padrão de certo/errado, intensificando a dimensão de controle e cerceamento do saber do 'outro', que percebe isso e deixa de falar o que pensa e sente.

As conversas que mantive com seu Jairo, dona Filó, dona Iracema, dona Jandira, dona Maria e Raquel, somadas às informações obtidas no bairro e à constante checagem e revisão do mapa oficial, levaram-me à conclusão de que uma nova cartografia estava se depreendendo no local. Havia diferenças entre categorias que eram traduzidas como doentes mentais mesmo e outras que só surgiam à margem desse campo, com uma intensidade menor como: aqui só tem depressão, aquela é só nervosa,... só deficientes mentais,... ou tem bastante é bêbado!

O doente mental mesmo do ponto de vista dos moradores é identificado pela fala e atitudes desconexas e bizarras que fogem ao padrão. É o variado, o louco, o doente da cabeça, o fora-de-si (que pode estar fora por algum trauma ou fraqueza na cabeça, por ter incorporado uma entidade ou, por ser "atentado" pela coisa ruim), a quem se imprime inclusive uma marca local dada pelo tipo de tratamento utilizado para a superação dessa situação: aquele que teve até no Bezerra! Mas se o critério é ter até estado lá, não é verdade que todos os internados sejam, da perspectiva dos moradores, doente mental mesmo. Aliás, há outra expressão bastante repetida quando as pessoas "conhecem" o funcionamento do hospital: lá eles misturam tudo!, para expressar, principalmente, a permanência de 
pessoas mais comprometidas junto com as demais e também, de alcoolistas e drogaditos no mesmo espaço físico dos outros internos.

Emerge das descrições do bairro a idéia de que o doente mental vive um conjunto de comportamentos problemáticos que 0 descentra, tornando-o um estranho para si mesmo; mas, ao mesmo tempo, as famílias e a vizinhança, em alguma medida, vinculam-no com o antes, com o seu processo histórico, social, cultural, permitindo assim, o (re) estabelecimento de conexões que possibilitam não romper radicalmente com a identidade anterior: do bom rapaz, do trabalhador, do vizinho. É evidente que todos convivem com as dificuldades em relação a sua condição de adoecimento, mas não se restringem a viver essa situação, nem têm presente essa "sintomatologia" o tempo todo. Aliás, durante o trabalho de campo, não presenciei nenhuma situação em que o sujeito se apresentasse "em crise" de modo tão marcante quanto às situações que recuperei nas diversas narrativas a mim trazidas para descrever os momentos desse sofrimento.

Embora outros elementos componentes do entorno de nosso universo empírico não sejam objeto de análise deste estudo, deles destacarei algumas particularidades pelo que representam na composição dessa cartografia, neste momento, no municipio de Passo Fundo. Estamos nos referindo à depressão, aos bêbados e drogados e a um grupo que me surpreende pelo número de pessoas lembradas com essas características: os deficientes físicos e mentais. Esses últimos, sempre marcados pela sua diferença: não caminham, freqüentam a APAE e são totalmente dependentes de alguém que cuide deles.

A depressão, embora apresente hoje vários matizes, chegando mesmo a ser banalizada, deve ser entendida como uma profunda e permanente tristeza que acaba por caracterizar o cotidiano da pessoa ${ }^{58}$. Dado que a sociedade atual permite um "alargamento" desta classificação/categoria, oriundo, quem sabe, da idéia de que hoje não há mais espaço para a frustração, para a tristeza, para a espera; em nosso

${ }^{58}$ Patologia médica grave. 
campo de pesquisa é também uma categoria a ser destacada pelo seu alargamento entre as pessoas com quem me relacionei no bairro. É o que está descrito em alguns fragmentos de dois adolescentes:

Diz Edson: Vou ao médico porque tô com depressão! Jovem de classe média baixa Edson, que trabalhava até há alguns meses atrás, queixa-se de não mais poder comprar os produtos de seu desejo - roupas, telefone, gastar em saidas noturnas - bens, através dos quais ele adquiria "status social", ficando, portanto, em evidência.

Luciani expressa-se assim: Tu sabe que eu também tô tomando remédio prá depressão? Eu me estresso de não fazer nada. Ontem eu ouvi no Ratinho (programa de televisão) um provérbio bem certo: 'mente desocupada é oficina do diabo', eu acho que é isso. Quem não tem o que fazer se deprime! O vizinho aqui da frente também se aposentou e entrou em depressão, ficou ruim, mas a depressão dele foi mais forte, $[. .$.$] acho que a minha é só$ um stress.

Lurdes, outra depoente, refere-se à depressão como doença de rico, expressão que eu já ouvira outras vezes no campo de pesquisa. Para ela, pobre tem é doença da cabeça e não adianta a gente querer ser rico se não é.

A terminologia ganha requinte de acordo com a classe social, mas, parece-me estar associada, sobretudo, à uma nova categorização decorrente do processo de civilização já estudado por alguns autores como Guattari, Rolnik e Birman.

Para Birman (2001) a complexidade do mundo contemporâneo tem gerado novas formas de subjetivação potencializadas pela sociedade da produção e do consumo que funciona como um círculo pecaminoso, onde a maior vitima é o jovem. Trata-se de um padrão inatingivel, oferecido para que as pessoas vivam de cena, de espetáculo. Esse novo mapa que coloca a falta permanentemente em cena, fora do mandato cultural, criando a todo o momento novas necessidades de consumo, vai gerando sofrimento e, por vezes, uma nova modalidade de depressão. Esta, por sua vez, encontra na indústria farmacêutica um arsenal de medicamentos cada vez maior para aliviar o sofrimento humano que, segundo o autor, é um dos interesses escusos dessa relação. 
A pessoa que vive essa depressão, por exemplo, não está fora-desi, desprovido da razão, como na doença da cabeça; ao contrário, ela está dentro-de-si, constituindo-se um paradoxo com aquele modelo da psicopatologia onde a categoria fora-de-si se caracterizava como inexistência da interioridade e o descentramento do sujeito. Para Birman (2001), a atualidade caminha numa outra direção: o que caracteriza a subjetividade na cultura narcísica é o excesso de exterioridade, atributo para que o sujeito possa gozar da admiração que provoca no olhar do outro, portanto, uma nova modalidade de sujeito fora-de-si que não é só o representado pelos quadros da psicose quando a exterioridade é pouco tolerada. Outra inversão perversa ocorre em relação aos fora-de-si da atualidade. Estes são socialmente integrados, valorizados e legitimados.

A drogadição, que atinge um público bastante jovem, foi se revelando mais pelo seu silêncio. Nas incursões pelo campo de pesquisa, comecei a perceber que essa era uma situação "não autorizada", sobre a qual era melhor não falar. Situação semelhante ocorria com os alcoolistas que, ora apareciam como bêbados, simbolizando a desgraça e a desagregação familiar, ora como alguém que, pela bebida havia se tornado doente da cabeça.

Embora essa situação possa fazer parte de uma "ignorância etnográfica" - marcada pelo preconceito e pela mitificação (PICCOLO, 2003, p.65) -, não posso deixar de registrar o meu receio em estabelecer relações com pessoas que viviam essa situação, particularmente as relacionadas às drogas ilícitas. Tive dificuldade de me aproximar desse grupo. São mais jovens e pertencentes a um universo predominantemente masculino segundo o mapa oficial. São, de modo geral, infratores. Mesmo assim, tive contato por um período relativamente longo com duas pessoas alcoolistas crônicas: o Antônio e o Iradi, ambos marcados por tentativas intercaladas entre "livrar-se do vício" e "entregar-se à cachaça". 
Discussões sobre essa temática tangenciaram várias vezes o cenário do estudo, como a nossa conversa com a promotora legal popular ${ }^{59}$, conversa essa em que ela apontou várias formas de violência vividas pelas mulheres no bairro. Dizia a promotora: Nós estamos discutindo um lugar para os maridos que violentam suas mulheres. Assim, não serão as mulheres a terem de sair de casa com os filhos; é melhor que elas fiquem, e eles, que têm problemas, saiam para se tratar. Perguntei-lhe que problemas tinham os maridos. Ela respondeu: Ih!, a maioria é bêbado! Segundo a promotora, esse problema fica mais restrito ao espaço privado, pois eles bebem na rua, e fazem "folia" dentro de casa, tornando mais difícil a denúncia pelas mulheres, principalmente porque vêm acompanhadas de ameaças, circulo de novas violências. Certeau $(2000$, p.50) e outros explicam como, através dessa relação entre o público representado pela rua e o privado representado pela casa, as pessoas, supostamente, alcoolistas, procuram manter sua integridade simbólica em relação às regras sociais do bairro.

Numa outra situação, após várias tentativas frustradas de obter informações a respeito de um morador, o L. Antônio, entendi tratar-se de alguém que não deveria ser "revelado". Sobre ele, nem dona Jandira, nem o Jairo, nem dona Filó quiseram falar claramente, fazendo apenas rápidas referências relativas a sua condição de "fora-de-si" e de drogado. Parece que o que assusta as pessoas, quando se referem a ele é o fato de ser fisicamente avantajado - é descrito como sendo um jovem forte - e andar sempre acompanhado de dois cachorros muito grandes.

Às vezes, o que impedia a aproximação de alguém, não era ele mesmo, como no caso de L. Antonio, mas os responsáveis por ele. Foi o que ocorreu na minha tentativa frustrada de aproximação com Jefferson. Fui aconselhada a não chegar diretamente porque seu pai era bicheiro e tomava uns "fogos".

\footnotetext{
${ }^{59}$ As Promotoras Legais Populares buscam contribuir para a difusão dos mecanismos de acesso e funcionamento da justiça entre uma camada específica da população: mulheres que desempenham o papel de lideranças comunitárias locais (www.sermulher.org.br/).
} 
Foi no entrelaçamento das falas e dos silêncios que percebi a existência dos reconhecidos, mas velados. Dona Jandira, ao falar de L. Antonio, limitou-se a dizer: bebe, depois que foi pra Caxias (para internação psiquiátrica) acalmou, mas ele fazia horrores... ele até pulava nas pessoas. Caso tu fores falar com ele, não revele o meu nome, mas acho melhor tu deixares ele de lado. O policial comunitário já me havia descrito essa pessoa, chamando-o pelo apelido. Analisando o material de campo, lembreime de alguém que eu conhecia do hospital, com o mesmo apelido e confirmei, posteriormente, tratar-se da mesma pessoa. Era usuário de drogas e adotava atitudes provocativas, que quase sempre acabavam em brigas, envolvimento com a polícia e internação psiquiátrica. $O$ medo que as pessoas sentiam dele, atingia também, os que trabalhavam no hospital. Eu própria vivenciei esse sentimento por ocasião da sua participação nos grupos de apoio que eu desenvolvia com os alunos, antes do início da pesquisa, o que me fez entender melhor o recado e a atitude da dona Jandira. Dele era melhor não falar muito, foi o que ela fez!

Em relação às questões dos usuários de drogas, encontro em Certeau et al. (2000, p.47) uma reflexão sobre a necessidade de convivência no bairro, importante para pensar sobre a reação desses moradores em relação a alguns dependentes de drogas, como uma problemática complexa enfrentada na sociedade atual. Eles lançam mão da noção de "conveniência" para esclarecer esta necessidade de reconhecimento social que se estabelece nas práticas cotidianas, afirmando que:

A prática do bairro é uma convenção coletiva tácita, não escrita, mas legivel para todos os usuários através dos códigos de linguagem e do comportamento. Toda a submissão a esses códigos, bem como toda a transgressão, constitui imediatamente objeto de comentários: existe uma norma, e ela é mesmo bastante pesada para realizar o jogo da exclusão social em face dos excêntricos as pessoas que não são/fazem como todos nós. Inversamente, é ela a manifestação de um contrato que tem uma contrapartida positiva: possibilitar a coexistência de parceiros, a priori não ligados. Um contrato, portanto, uma coerção que obriga cada um para que a vida do coletivo público - o bairro - seja possivel para todos. 
A vivência no bairro implica reconhecimento e adesão "[...] a um sistema de valores e comportamentos que força cada um a se conservar por trás de uma máscara para sair-se bem no seu papel". Talvez, o desconforto dos vizinhos ou familiares, as "meias-palavras", o silêncio de alguém que nasceu e morou na mesma rua, estejam sintonizados com o rompimento desses códigos de reconhecimento de alguém que transgrediu esse sistema já que é um comportamento que "fala" da violência, do medo, da estranheza de algo/alguém que poderia estar afastado da vida cotidiana.

Foi assim que compus esse repertório e me aproximei do ponto de vista dos moradores. A cartografia oficial, que serviu de trilha inicial, ajudoume a perceber desde $o$ início do trabalho, os imaginários do bairro, que colocavam em cena diferenças nas suas classificações, mas principalmente nos sentidos que produziam a respeito dos fora-de-si, do doente mental mesmo. Conforme Venturini, viver o cotidiano da cidade, permite àquele que muitas vezes fica "à margem da história (talvez no nosso fazer profissional), tornar-se autor da própria vida, exceder o papel de doente, e deslocar-se em direção a outros papéis: o de cidadão, de portador de direitos, de consumidor, de produtor" (VENTURINI, 2003, p.183).

\subsection{As trajetórias dos protagonistas}

Enquanto vivo, sonho...
E o mundo se esconde
Brinca de onde
Mora a felicidade
Enquanto sonho, busco...
Busco um horizonte
Nem perto, nem longe
Onde, enfim, eu me encontre.
(Poema sem título de Henrique Clarency Laporta de Porto
Alegre/RS, publicado em Arte de Viver, 2001)

Compreendemos que cada protagonista é uma unidade complexa (MORIN, 2002) que têm tramas muito singulares, construídas de redes sociais, afetivas, institucionais, que thes possibilita circulações diferentes, sendo passíveis de viver o caos e a reorganização, a ruptura e as conexões, 
a existência-sofrimento e a saúde em processo de interação e retroação contínuos.

Essas redes que compõem cartografias foram ganhando forma e sentido ao longo da pesquisa. É desta perspectiva que nos apoiamos no conceito de trajeto construído por Magnani nas pesquisas sobre a metrópole. Neste estudo, além de ressignificar o conceito para adequá-lo à nossa temática, vamos chamá-lo: trajetória. As trajetórias podem ser entendidas como expressões da produção subjetiva que possibilitam ao sujeito experienciar diferentes maneiras de perceber o mundo e de se articular com ele. Retenho como fundamental nessas trajetórias a noção de que a subjetividade está sempre em movimento, através das diversas maneiras pelas quais os sujeitos e as coletividades se constituem e são constituídos e, cujos sentidos, têm de ser descobertos nos contextos em que são produzidos.

Essa perspectiva dialoga com González Rey (2003) para quem a subjetividade representa um macro conceito orientado à compreensão da psique como "sistema complexo", afetado pelo próprio curso da sociedade e das pessoas que a constituem, dentro do contínuo movimento das redes de relações que caracterizam o desenvolvimento social. Dessa forma, recorrendo também ao pensamento de Morin, o autor afirma que esse macro conceito representa realidades diversas, que em suas próprias dinâmicas modificam sua auto-organização, conduzindo de forma permanente a uma tensão entre processos gerados pelo sistema e suas formas de autoorganização, as quais também são comprometidas com todos os processos do sistema. Nessa perspectiva a subjetividade é produzida de forma simultânea no nível social e individual, através de um processo recursivo.

Vejamos a compreensão de González Rey (2003, p.241). Ele apresenta a subjetividade em sua dimensão individual e social, sendo que a primeira "representa os processos e formas de organização subjetiva dentro dos individuos concretos. Nela aparece constituida a história única de cada um dos indivíduos, que, em uma cultura se constitui em suas relações 
pessoais". Vivendo essas relações e experiências em uma cultura de idéias e valores próprios, vai se constituindo, ou seja, construindo sentido para as experiências que vivencia. A dimensão social da subjetividade "como um sistema complexo exibe formas de organização igualmente complexas, ligadas aos diferentes processos de institucionalização e ação dos sujeitos nos diferentes espaços da vida social, dentro dos quais se articulam elementos de sentido, procedentes de outros espaços sociais". Além dos elementos imediatos dos processos sociais do sujeito em sofrimento psíquico, como as relações mais estreitas com os serviços de saúde mental, podemos mencionar outros elementos que integram à constituição subjetiva, como gênero, classe social, costumes locais, constituição familiar, etc.

A subjetividade individual passa por "diferentes contextos sociais de subjetivação, se constitui dentro deles e, simultaneamente, atua como um elemento diferenciado do desenvolvimento dessa subjetividade social, que pode converter-se em um elemento de tensão e ruptura, que conduz ao desenvolvimento da própria subjetividade social" (2003, p.205, grifo nosso) Assim sendo, as dimensões da subjetividade social e individual se expressam como momentos contraditórios que se integram de forma tensa na constituição complexa da subjetividade. De outra forma, a condição do sujeito individual se define "somente dentro do tecido social em que o homem vive, no qual os processos de subjetividade individual são um momento da subjetividade social, momentos que se constituem de forma recíproca sem que um se dilua no outro, e que têm de ser compreendidos em sua dimensão processual permanente" (2003, p.206). Transpondo a compreensão de González Rey para as trajetórias construídas pelos protagonistas, essas se formam na confluência de uma série de forças sociais que operam sobre ele cotidianamente e, diante das quais, ele também opera e se constitui como sujeito.

Rolnik (1997, p.15) ao problematizar a questão da subjetividade através de uma "viagem virtual" mostra esse caráter processual da produção subjetiva referindo-se a um dentro e um fora de cada figura que se esboça: 
- que percebemos é que eles são indissociáveis e, paradoxalmente, inconciliáveis. O dentro detém o fora e o fora desmancha o dentro. Vejamos como: o dentro é uma desintensificação dos movimentos de forças do fora, cristalizadas temporariamente num determinado diagrama que ganha corpo numa figura com seu microcosmo; o fora é permanente agitação de forças que acaba desfazendo a dobra e seu dentro, diluindo a figura atual da subjetividade até que outra se perfile.

Guattari e Rolnik (2000, p.26) destacam que a subjetividade é produzida através de mecanismos e estratégias mais diversos na sociedade, como, por exemplo, pela mídia e por diferentes equipamentos sociais. Para esses autores, as mutações contemporâneas da subjetividade não se fazem apenas pelas vias das ideologias, das idéias, "mas (se fazem) no próprio coração dos indivíduos, em sua maneira de perceber o mundo, de se articular com o tecido urbano, com os processos maquínicos do trabalho, com a ordem social suporte dessas forças produtivas", fazendo com que tenhamos na atualidade, um poder de controle para forjar uma subjetividade serializada, uma padronização do próprio desejo segundo normas e comportamentos que são sutilmente interiorizados e disseminados nas relações, substituindo os "tradicionais" dispositivos disciplinares de confinamento.

No entanto, há também potencialidades de resistência, de escapes, através de modos de subjetivação singulares (revoluções moleculares) que seriam uma maneira "para construir, de certa forma, modos de sensibilidade, modos de relação com o outro, modos de produção, modos de criatividade [...] que coincida com um desejo, com um gosto de viver, com uma vontade de construir o mundo no qual nos encontramos [...]" (GUATTARI E ROLNIK, 2000 , p.17). Para que se efetivem os processos de reapropriação da subjetividade, as pessoas devem criar, inventar, seus próprios universos de referência, suas próprias cartografias de modo a fazer brechas às formas de subjetividade dominantes. Assim, constituiria-se a singularização, uma das dimensões essenciais do processo de construção da subjetividade no nível individual. 
Assim, entendo as trajetórias dos protagonistas como escolhas construídas e conquistadas no entrelaçamento das dimensões individuais e sociais, que indicam que certas circunstâncias (pessoas, situações, lembranças) trazem-lhes suporte para se apropriarem dos espaços, interagirem com pessoas, produzirem situações desejadas, retornarem a lugares que thes dão/ou onde esperam ter apoio, acolhimento e autonomia. No entanto, existe também, nos entremeados desses percursos, as "nãoescolhas", ou seja: trata-se de situações não protagonizadas nem desejadas por eles, mas que estão instituídas e presentes ao mesmo tempo em suas vidas. Esse tensionamento de sujeitos em certas situações e de sujeitados em outras, ora construindo "brechas de fuga", ora se rendendo ao que já não vem mais ao encontro das suas necessidades, está vivo e pulsante nas inter-relações cotidianas.

As situações que aqui reúno referem-se ao acesso cotidiano de pequenos analisadores do percurso como o caminho, as pessoas, os assuntos, os sentimentos, as expressões, procurando captar as articulações desses diferentes mundos com a produção subjetiva. Mundos que circulavam entre extremos, como a aceleração veloz cavando espaços de vida e a inércia, a livre circulação na cidade e a rápida captura institucional; fazendo-me sentir "traída" por um "poder invisivel" que, sutilmente, retirava de cena os protagonistas e de certa forma também controlava o meu fazer, na medida em que me deslocava para determinados lugares que silenciavam essas construções subjetivas, "artificializando" e restringindo as relações. Essas trajetórias, do meu ponto de vista, configuram a própria protagonização, ou seja, ainda que na existência de um sofrimento, esses sujeitos não perdem a capacidade de desejo e de encantamento pela vida, construindo suas histórias no contexto em que vivem, lutando contra a definição apriorística dada por um determinado conhecimento que, por vezes, faz calar esse lugar.

Para efeito de sistematização do texto, abordarei a seguir as trajetórias que os protagonistas constroem no espaço da cidade, 
particularmente fora das instituições de saúde, deixando essas para o capítulo posterior.

\subsubsection{Uma travessia de resistência a um jeito dominante}

O controle diário no espaço domiciliar era visível no corpo de Joãode-Barro que, pouco coordenado, saía do quarto sonolento, cambaleando pela contenção química decorrente das altas doses de medicamentos. Em alguns períodos, era freqüente encontrá-lo dormindo durante boa parte do dia, conforme registra sua mãe: ele sempre dorme a tarde, senão fica caindo pelos cantos.

As altas doses de medicamentos colocavam-no diante de um dilema. Se, de um lado, contribuiam para aliviar suas "crises"; de outro, deixavam-no num lugar de "inutilidade", freqüentemente expresso por ele através da frase: assim eu não vivo. De fato, essa era uma condição que o desvitalizava, impedindo-o de produzir os arranjos que demonstravam que os seus direitos não podiam ser violados. Uma luta que travou cotidianamente nos diferentes espaços institucionais, registrando em cada relação a sua marca contra a dependência, contra o que não o deixava viver com autonomia e dignidade. Leituras nem sempre feitas ou aceitas nos espaços vividos, o que fazia com que ele lançasse mão de outros artifícios e arranjos para ser escutado ou desviar-se dos controles estabelecidos.

$\mathrm{Na}$ familia onde vive com os pais, a relação "doença/remédio/serviços de saúde" ganha uma dimensão bastante intensa, envolvendo seus membros em discussões e buscas que tomam a maior parte do tempo, sendo o próprio João-de-Barro, quem cuida de tudo o que necessita ser feito para viabilizar o tratamento (carimbar exames, solicitar autorização de internação, buscar remédio, falar com a coordenação de saúde mental, quando algum encaminhamento não ocorre a seu contento, etc.). Ele viveu muito, durante o tempo em que mantivemos contato, nas instituições: hospital psiquiátrico, hospital geral e Caps. Nos primeiros meses 
da pesquisa de campo, pude observar que a passagem pelo hospital psiquiátrico foi dando espaço a outras instituições e necessidades.

É usuário intensivo do circuito de atenção à saúde, desde que apresentou "esses problemas", mas está sempre (re)construindo e (res)significando sua existência nesse percurso. Inicialmente, nos tempos dramáticos da manifestação de seu sofrimento, centrava esforços na disponibilização de todo o aparato tecnológico (exames, remédios) para descobrir e tratar o que Ihe provocava tanta dor física e emocional. Passada essa fase aguda, foi sentindo a metamorfose ${ }^{60}$ que esse processo provocou em sua vida. Começa, então, a lutar por espaços que possam "mantê-lo vivo", trazendo um conjunto de necessidades que envolvem conflitos familiares, sua paternidade, trabalho e moradia, enfim, todo um processo conflitivo que constitui essa mudança em sua identidade. De operário, marido, pai, morador da sua própria casa, passou a ser assegurado, depois aposentado por invalidez, separado (da esposa e filho), voltou a morar com os pais e a viver um conjunto de outros fluxos existenciais.

Seu cotidiano é marcado por inúmeras estratégias que "arma" por dentro dos serviços, fazendo sempre um grande esforço para que haja conexão, ou seja, para que, de fato, funcione em rede. Assim, ao ser encaminhado do Centro de Atenção Integral à Saúde (Cais) para o hospital, solicita gentil, mas insistentemente, que a vaga seja "garantida" pelo serviço que o encaminhou; ou, ao receber o deferimento de um processo judicial contra o Estado, vai à Coordenação Regional de Saúde e exige que seja respeitado o tempo para disponibilizar seu medicamento ou exame, apenas para citar alguns exemplos. Mas a marca mais intensa é poder "viver", que

\footnotetext{
${ }^{60}$ Termo usado por Gilberto Velho $(1999$, p.29) para dizer que nós nos movimentamos e nos desenvolvemos entre diferentes mundos e significados. Afirma que os indivíduos, "[...] mesmo nas passagens e trânsitos entre domínios e experiências mais diversificadas, mantém em geral uma identidade vinculada a grupos de referência e implementada através de mecanismos socializadores básicos contrastivos, como família, etnia, região, vizinhança, religião, etc. A tendência à fragmentação não anula totalmente certas âncoras fundamentais que podem ser acionadas em momentos estratégicos. Por outro lado, a fragmentação não pode ser entendida como um estraçalhamento literal do individuo psicológico. $O$ transito entre os diferentes mundos, planos e províncias é possivel, justamente, graças a natureza simbólica da construção social da realidade.
} 
para ele significa poder reconstruir sua vida afetiva como pai, conviver mais com o filho, ter o seu "canto", cuidar das suas "coisinhas" (refere-se aos móveis, seus pertences) e, quem sabe até, ter uma nova companheira. Ao se sentir distanciado desse enigma, e diante da gravidade do problema de saúde, não pára de pensar no "fim", no seu fim concreto.

No espaço doméstico, usa o tempo conversando com seus pais, irmã e sobrinhas. Vive, também, fortes conflitos oriundos da rigidez de um de seus familiares que resiste em aceitar que o seu comportamento é resultado de um processo de adoecimento. Ajuda em algumas atividades domésticas como capinar e limpar o pátio, secar a louça, cuida da conta bancária e sabe administrar muito bem o seu dinheiro, destinando parte da aposentadoria à pensão do filho, o que demonstra sua responsabilidade diante da situação: 0 juiz disse que não era obrigado, porque sou aposentado por invalidez, mas eu faço questão de dar as coisas pra ele, é meu filho. Meu sentimento é não poder trazer ele comigo! Mesmo diante da impossibilidade de viver com o filho, esforça-se muito, com o auxilio de sua mãe, para manter-se próximo e exercitar sua paternidade.

Procura encontrar-se com o filho nos fins de semana, ou em ocasiōes especiais, quando sente que a responsabilidade de pai assim o exige, como por exemplo, nas circunstâncias em que o menino foi encaminhado (pela creche) para consulta médica. Embora viva situações de tensão com sua ex-mulher que prefere não compartilhar determinados acontecimentos, ele se mantém informado e participante da vida do filho, através das funcionárias da creche, estando presente sempre que a situação requer que assim o faça.

João-de-Barro não esquece de datas comemorativas, como os aniversários (seu e do filho), o Natal, a Páscoa, celebrando, na medida do possivel, com seus familiares e amigos mais próximos. Ele próprio, com o auxilio de sua mãe organiza a festa, sai com o filho para comprar-the roupas, presentes e fazer os convites, como o que recebi no último aniversário: eu tenho que saber se a senhora não tem compromisso no dia oito de maio, 
porque eu quero marcar o aniversário do guri, mas quero que a senhora venha, então já tô lhe consultando antes de acertar a festa...

Seus fins de semana são marcados ainda pela freqüência a missa dominical na igreja "São João Operário" juntamente com sua mãe e pelos passeios nas casas dos irmãos. Nas noites de verão sai com freqüência para passear até o centro em companhia da mãe ou sozinho para fazer um lanche e arejar a cabeça.

Pude perceber que a rede de relações no bairro é bastante intensa e, na maioria das situações que presenciei, a solidariedade e a afetividade foram marcas distintas. Nas caminhadas pelo bairro, ele me surpreendeu algumas vezes com interações dessa natureza, como por exemplo, nas situações que descrevo abaixo:

Após uma noite não dormida em que passou caminhando pelas ruas da cidade e com um nivel de ansiedade bastante elevado, convidou-me para continuar caminhando pelo bairro, pois a situação parecia piorar em casa. Disse-me que não estava conseguindo se alimentar nos últimos dias. Quando voltávamos pediu-me que the pagasse um lanche e convidou-me para ir ali na dona Juracil (Sua mãe já me falara dessa mulher, sugerindo que João-de-Barro estivesse mantendo uma relação afetiva com ela: uma velha do bar). A porta estava entreaberta e ele foi entrando:

- Dona Juraci, preciso de um cachorro quente.

Ela respondeu:

- Oh João-de-Barro, não tenho pão, hoje é feriado e eu não consegui abastecer.

Veio em direção ao bar, onde estávamos. Uma pequena peça acoplada a sua casa. Afetivamente, cumprimentou-o brincando e dizendo que não Ihe daria comida. Ele responde no mesmo tom de brincadeira:

- Se não me deres faço uma quebradeira por aqui. Riram juntos e ele disse:

-Quero te apresentar a minha doutora...

-Tá vendo João-de-Barro (disse a mulher) como tu tens pessoas que gostam de ti. A doutora veio te ver aqui e num feriado e você mesmo assim não quer viver! (estava se referindo aos episódios das últimas semanas em que João-de-Barro havia tentado suicídio duas vezes). Os olhos dele marejaram com o abraço emocionado da mulher:

-Esse menino é de ouro, tem crédito com as pessoas. Aqui todo o mundo gosta dele. É responsável, se vira sozinho, nunca deixa de pagar as contas. 
Após alguns minutos de conversa ela ofereceu-lhe um hambúrguer e João-de-Barro só aceitou esperar o lanche se entrássemos na casa de dona Juraci. Apesar de constrangida com a desordem por causa da limpeza, convidou-nos a entrar e a conversa continuou. Enquanto ela preparava o lanche, João-de-Barro contou-lhe da angústia vivida nas últimas horas por causa do sentimento semelhante ao "cabo de guerra". Ela ouvia e dizia-lhe que precisava fazer alianças com o lado que queria viver. Falava com ele e comigo: Esse rapaz tem um filho lindo que precisa e que gosta dele. Tu tinhas que ver quando ele tinha a casinha dele - quando ainda era casado -, ele não deixava faltar nada. Sempre foi organizado e cuidou de tudo. Tem os irmãos e a mãe que também gostam muito dele,... Enfim, foi mostrando que ele era uma pessoa especial para a família e para a vizinhança, mas precisa se ajudar também, reforçou ela.

João-de-Barro parecia mais tranqüilo. Comeu o lanche na mesa da cozinha, falando com Juraci, comigo e com as meninas (sobrinhas de Juraci), apresentando-me a cada uma delas. O clima era de cordialidade. Dona Juraci contou-me que era espírita e que já havia convidado João-deBarro várias vezes para ir ao Centro Espírita Dias da Cruz receber um passe e fazer umas orações. Disse que passavam pelo Centro muitas pessoas com problema semelhante ao dele. Após ouvi-la quieto, perguntouIhe se já havia ligado (entendi que era algo referente ao assunto do Centro Espírita). Ela respondeu que ligaria à tarde. Era um sinal de que outros arranjos estavam por acontecer com a ajuda de dona Juraci.

Num outro momento em que caminhávamos juntos, ele disse que gostaria muito de me apresentar a uma pessoa, também vizinha, que era a sua madrinha. Há tempos ela fazia parte do seu repertório. Aceitei o convite e fomos até lá. Ao chegar, João-de-Barro foi recebido calorosamente por uma senhora, dona Joana. Fomos apresentadas. João-de-Barro lembrou do padrinho falecido no último verão, de quem também gostava muito. Soube que João-de-Barro passa por lá todos os dias para pedir a benção, oferecer ajuda ou usar o telefone. Diz ela: ele sabe que eu estou aqui. Quando ele precisa, pode vir que eu ajudo no que eu posso. Durante a nossa visita 
chegou a neta de dona Joana que dorme todos os dias na casa da avó, depois da morte do avô. Qualquer coisa que aconteça comigo ela chama o meu filho que mora ali nos fundos e se acontecer com ela, eu também chamo.

As relações familiares são bastante sólidas nesse local. Os mais novos vão cuidando dos mais velhos, e todos cuidam dos doentes. Nosso protagonista é também bastante habilidoso na construção e preservação dessas relações. No entanto, quando esses espaços se distanciam ou se conectam com pessoas de fora de um campo de relações mais próximas, semelhante ao que Magnani $(2000,2002)$ denominou como pedaço, percebe-se que há diferenças nas interações, salientando-se, muitas vezes, comportamentos ameaçadores e estigmatizantes. Ilustrativo dessa relação foi o episódio com um motorista do coletivo urbano que, com freqüência, deixava no ponto de ônibus nosso sujeito de pesquisa por se tratar de uma pessoa diferente, "cambaleante" e que não poderia ser conduzida junto aos demais.

No cotidiano do nosso protagonista, a questão do trabalho e o desejo de fazer algo valorizado socialmente eram uma constante, tanto nos seus diálogos nem sempre explicitos com o Caps, mas expressos pela resistência em participar das oficinas terapêuticas, alegando que o que estava sendo proposto não vinha ao encontro das suas necessidades, como na rede familiar (conjeturaram sobre possibilidade de abrir lavagem expressa de carros, estufa de verduras). Certa vez foi trabalhar num bar de um amigo que conhecia seu problema e o empregou sem carteira assinada para que não perdesse a aposentadoria. Mas, logo surgiram as limitações, deixando-o profundamente frustrado: perdi por um piá de 11 anos, ele sabe mais que eu. Eu não conseguia lembrar dos pedidos, me atrapalhava todo, não tinha agilidade necessária pra pegar as coisas, demorava muito... Ai cheguei e eu mesmo falei pro meu amigo que eu iria sair pra não prejudicar o negócio dele. Ele aceitou, porque era verdade. 
Contou-me que levou sua frustração ao atendimento com um profissional de quem ouviu a seguinte explicação: você está aposentado exatamente porque tem uma doença que o limita a trabalhar.

\begin{abstract}
Eu sei que o doutor está correto no que ele fala, mas ser aposentado por invalidez não me conforta. Eu quero e preciso desse dinheiro, até porque não vão me dar trabalho e eu nem posso voltar a ser ajudante de obra com essa carga de remédio e desse jeito, com essa lerdeza. Além disso, eu tenho que sustentar o piá, mas não me satisfaço em não poder fazer nada.
\end{abstract}

Ouviu ainda dos profissionais de saúde que ele deveria ter buscado uma orientação antes de tentar o trabalho, mas que agora, a equipe conhecedora do seu desejo, poderia desenvolver com ele, aspectos relacionados a cálculos, memória, agilidade, etc. Há de se registrar que não havia nenhum projeto (até o momento da pesquisa de campo) de trabalho junto aos serviços de saúde. As propostas terapêuticas relacionadas a habilidade são sugeridas nos atendimentos grupais, particularmente nas oficinas terapêuticas que são "estabelecidas de acordo com a necessidade do grupo e com a orientação da equipe técnica [...] (PASSO FUNDO, 2000). João-de-Barro relata que o que mais gostava de fazer eram as tapeçarias, realizadas em oficinas com acadêmicos, mas que agora não são mais desenvolvidas. Ele diz que as "atividades" propostas atualmente não despertam o seu interesse, pois não contribuem para aprofundar o conhecimento em determinada área: é só desenho, cestas,... Ainda que os dispositivos de atenção à saúde sejam relativamente novos e tenham determinados propósitos, o que observamos é que as atividades profissionais continuam relacionadas a papeis prescritos, criando ciladas que, em lugar de ajudar, reiteram a incapacidade, sem considerar que a situação de cada um também tem que ser relativizada. 


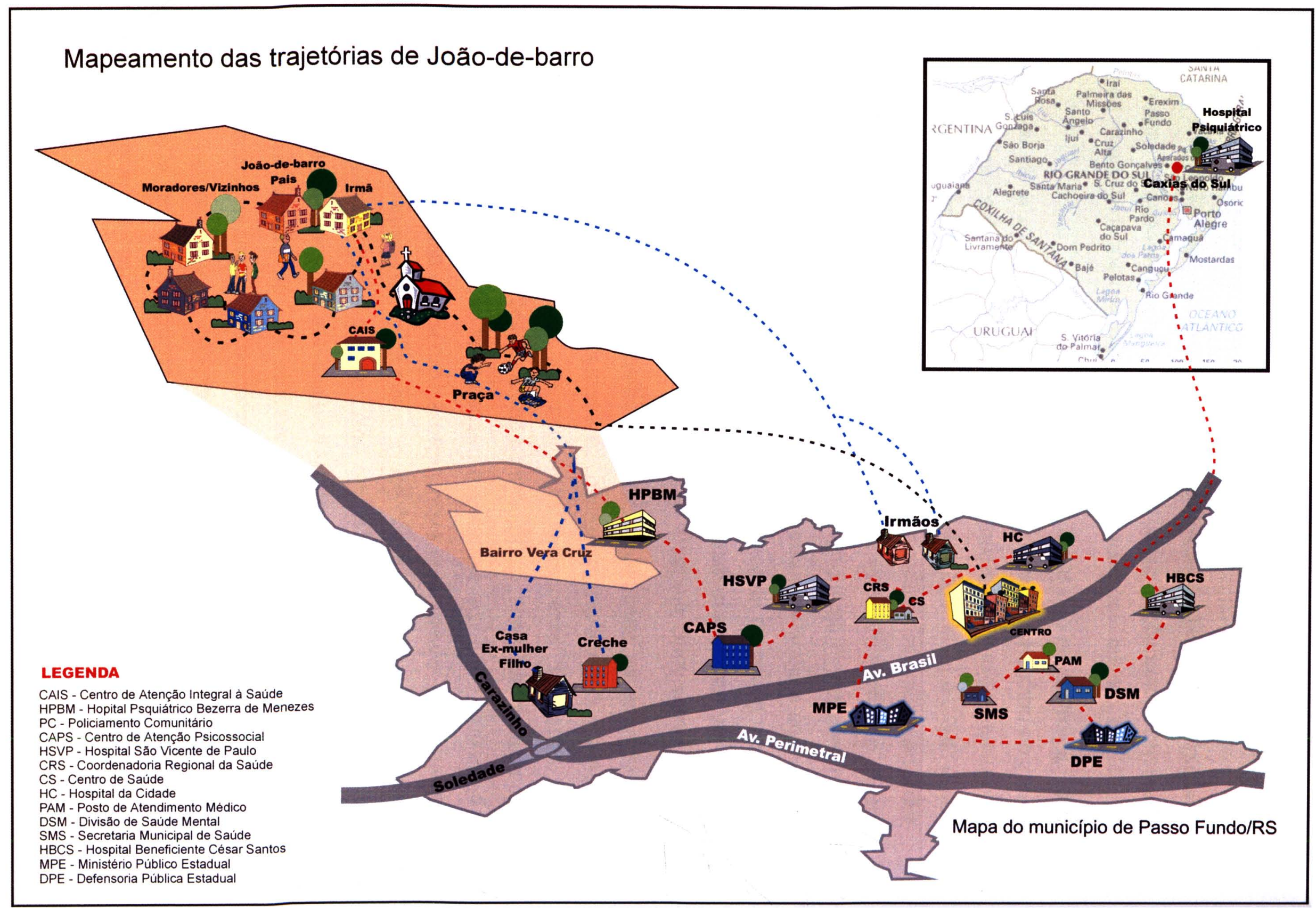




\subsubsection{No drible entre a liberdade e a captura}

Beija-Flor tem seu dia, rotineiramente, preenchido por uma imensa variedade de lugares vividos na rua. Sai, ao clarear do dia, a construir cenários balizados, principalmente, por seu desejo. Acompanhá-lo nessa "rotina" diária é difícil, pois suas paradas são tão rápidas quanto seus passos. Num comentário que fez durante um de nossos encontros, apresentou-me uma estratégia de convivência que, em seu julgamento, não Ihe causa maiores problemas: não gosto de "xaropear" ninguém, fico um pouco e caio fora! Ele sabe, como ninguém, o momento em que sua presença não agrada e já criou defesas para evitar desafetos: aproveita rapidamente o que the interessa e busca novos cenários. Além disso, ele está sempre "antenado" em relação ao que se passa à volta, e ao que posso estar pensando. Seus traços paranóides, por vezes, me deixam bastante insegura, o que me faz "abrir-mão" da estratégia de dialogar com pessoas que efetivamente participam mais de sua trajetória.

Assim como em seus percursos cotidianos as cenas passam muito rápidas em seu pensamento, fazendo parecer que não tem tolerância para ficar muito tempo no mesmo assunto. Em um rápido encontro me fala com alegria dos amigos, das meninas da escola, das namoradas, do trabalho, das "encrencas". Percebo que as "encrencas" são mais relacionadas a sua família do que à rua, embora tenha presenciado uma "encrenca" na rua alguns meninos disseram-lhe qualquer coisa a que ele respondeu bravo: oh, vocês calem a boca, não vêem que eu estou conversando com ela aquil Foi tudo muito rápido, só percebi a hostilidade dos meninos que saíram rindo dele. Sua reação negativa estendeu-se a mim: se for pra ti ir lá em casa pra falar de hospital eu não quero, nem vá!

Os atritos familiares são constantes, sempre pautados pelas sucessivas internações feitas, via de regra, contra sua vontade, além do descrédito e da desqualificação que se atribui àquilo que fala ou faz.

Com relação a sua familia, demorei para entender determinadas falas, como, por exemplo, em que momentos eu poderia chegar na sua 
casa, oh venha num horário que eu esteja em casa, ou, a mãe e minhas irmãs não tem condiçōes de conversa. Sempre sinalizava para sua familia que eu estava na sua casa para conversar com ele, não tolerando muitas interferências ou comentários a seu respeito na minha presença. Essa era uma dimensão de valor fundamental em que ele era o protagonista, sem um porta-voz como em quase todos os momentos de sua vida. Essa situação gerava determinados constrangimentos:

\begin{abstract}
Percebo atrito entre eles algumas vezes. O Beija-Flor tenta ignorar os outros e procura falar somente comigo. Quando alguém fala alguma coisa que ele não quer ouvir, sua atitude é de repulsa: fala alto com a pessoa e sai do lugar. Primeiro foi com a mãe quando ela desqualifica sua fala com uma sorriso e um comentário, no momento em que ele falara que também cuidava da casa quando ela (mãe) precisava sair. Dona Genésia responde:
\end{abstract}

Se depender dele pra cuidar da casa os ladröes entram e levam tudo, porque a gente combina com ele, mas quando chega em casa não tem nem rastro do Beija-Flor.

Ele se levanta e grita que desse jeito ele não fala mais. A mãe se constrange um pouco, pede desculpa, se levanta se retirando do pátio. Depois a irmã que é tutora chegou e parou na porta enquanto ele conversava. De imediato Beija-Flor parou de conversar e ficou olhando pra ela. De repente falou: não vai sair?

Não! Respondeu.

Ele se levantou e disse: $A$ Bermadete veio aqui por causa de quem? Então saio eu! A irmã deu um sorriso aparentou estar fazendo uma brincadeira, retirando-se do local.

Sendo assim, quando o encontro em sua casa, procura sempre me retirar da convivência com os demais. Cria alguma estratégia, como me convidar para tomar um café no porão, ou ver a sua televisão. O "seu quarto", cômodo que abriga sua intimidade, seus objetos de valor, è uma garagem que fica no porão da casa da mãe, um local que cheira a combustivel. Uma cama, uma TV colorida (que ele manuseia com muito afeto) e um pequeno baú com seus pertences formam seu pequeno mundo. Há, também, o café com leite na garrafa térmica que a mãe faz para que ele não lide com fogo, com medo das convulsões e do seu esquecimento; é o café com leite que lhe garante a energia nos intervalos das caminhadas ou à noite em frente à televisão. A organização de um "lugarzinho" para ele 
dormir, deu-se, segundo a mãe, devido ao fato dele acordar muito cedo, pela manhã, e, às vezes, levantar à noite, indo para a cozinha, causando preocupação e necessidade constantes de acompanhamento.

Parece que ele acompanha as dificuldades da vida em família através da rotina da casa e retorna para obter dela, principalmente, aquilo que the é imprescindivel: o abrigo, a alimentação e o remédio. Percebo que a casa (da família), ainda que é o seu lugar de referência, é um lugar ambiguo, onde ele tem abrigo e alimentação, mas não estabelece com este espaço social relações de proximidade e proteção que desperte sua vontade de voltar quando está longe. Em outras palavras, a casa parece ser um lugar necessário para o suprimento de necessidades concretas de comer, dormir, de socializar alguns acontecimentos, desde que o dia amanheça logo para que possa continuar dando sentido a sua vida em um espaço mais fluido, com regras mais flexiveis que ele consiga suportar e ali se expandir, reorganizando-se como um equilibrista tecendo o seu caminho.

À primeira vista, o encadeamento das cenas que compõem o cotidiano parece sem sentido, surreal, regrado pela errância desmedida, mas é nessa atividade física intensa, difícil de acompanhar e na surpreendente condição de o encontrar em diversos lugares, compondo diversos cenários (reais e imaginários) que the vem a possibilidade de "oxigenar" o que há de mais humano em nós: "a necessidade de dar sentido" a nossa existência (PANDJIARJIAN, 2000, p.63). Há um "enganchamento" das cenas cotidianas com a sua subjetividade, particularmente na busca de preservação e ativação de um certo sujeito que expressa, "à flor da pele", sua necessidade de uma vida onde o belo, o atraente, o desejado são elementos a serem buscados constantemente e em doses micro.

Um encontro inesperado e quase relâmpago com Beija-Flor suscitou-me uma reflexão importante, seguramente um dos momentos marcantes do trabalho, por ter me despertado para determinadas dimensões subjetivas, criadoras de saidas para sua existência. 
me acompanhar até o carro, dando-me um calendário que havia apanhado no chão. Tratei de perguntar se o calendário era do ano, e vi que ele não tinha valorizado esse dado, não sabia se era atual ou não porque tinha prestado atenção às fotos. $\mathrm{Na}$ verdade, as fotos eram lindas. Percebi então, que nossos diálogos não estavam sincronizados. Para ele, o tempo contado em ano ou dias não era o mais importante naquele objeto. Enquanto eu valorizava o racional e pragmático, Beija-Flor valorizava o sensivel, o estético. Agradeci, disfarcei a minha falta de sensibilidade e disse-lhe que as fotos eram muito bonitas mesmo. Esse "agrado" constituiu-se em estratégia de aproximação que passou a ser uma constante nos nossos encontros, quando ele fazia questão de me presentear com revistas, calendários, figuras, etc, assim também com outras pessoas. Era o seu jeito de dizer que fazia bem me encontrar, ser visitado por mim, ser meu amigo. Foi "simbolicamente" este encontro que me fez perceber que ai existiam outras trajetórias para além das instituídas, outras produções subjetivas, outros mapas que nos transportam a outros planos ${ }^{6 !}$, desde que treinemos o olhar e escapemos da produção padronizada do mundo "psi". Nesse limiar "marginal" é que emergem formas de sociabilidade, de trabalho, de vida que fazem deslocar as tradicionais concepções e o nosso papel profissional e institucional de trabalhadores da saúde mental. Senti, de repente, um encantamento por ele, algo contrastante com minha resistência no processo inicial da pesquisa pelo seu jeito "errante e instável" afetivamente; momento em que também me encontrava impregnada pelo mesmo "olhar" de fora, talvez mais próxima à leitura que alguns familiares e profissionais de saúde faziam dele.

Viver as experiências da rua, traz a Beija-Flor um cenário dinâmico, que, embora carregado de incertezas, satisfaz necessidades ou expectativas. É preciso ter em mente que os outros cenários de sua vida estão centrados entre a casa e o hospital. Na rua, dá-se o encontro de momentos lúdicos de um rapaz que, aos 40 anos, conserva um visual de menino e mantém desejos de ter amigos, namorada, casamento e trabalho.

Morador desse local desde o nascimento, o bairro parece estar imbricado na alma de Beija-Flor que reconhece o seu cheiro, as suas ruas, os moradores, os seus ritmos, recebe as novidades, rejeita o que lhe é estranho. Nesse sentido, a cidade revela as relações com os outros e com o

\footnotetext{
${ }^{61}$ Planos que, segundo Guattari (1992) apontam para outros movimentos emergentes de produção de conhecimento sem nenhuma ordem pré-definida, a partir da atuação em vários campos simultâneos, práticos e teóricos, de organização de grupos de interesse, de agenciamentos entre diferentes instâncias sociais de serviços, de ação politica ou criadora, artistica, técnica etc. É evidente que isto implica a desmontagem das fronteiras que promovem a segregação em relação a outros olhares.
} 
ambiente, possibilitando, no dizer de Simmel, guardar aspectos de uma pequena cidade, onde, "o ritmo da vida e do conjunto sensorial de imagens mentais flui mais lentamente (se comparado à metrópole), de modo mais habitual e mais uniforme [...] descansa mais sobre relacionamentos profundamente sentidos e emocionais" (SIMMEL, 1979, p.12). Os fundamentos sensoriais da vida psíquica nas cidades, desenvolvidos por esse autor, parecem também se apresentar como um aliado a sua personalidade agitada, possibilitando conexões em niveis "mais inconscientes do psiquismo e crescem sem grande dificuldade ao ritmo constante (ou quase) da aquisição ininterrupta de hábitos".

Essa necessidade de um porto a assegurar-lhe um mínimo de estabilidade pode ser percebida na forma como construiu a noção de espacialidade. Por ter tido convulsões desde criança, não foi estimulado pela família a sair de casa, mantendo-se até o final da adolescência nas intermediações do bairro, não conhecendo nem mesmo o centro da cidade, embora tivesse muita vontade de conhecer. Analfabeto, criou suas próprias estratégias de aprendizado. Passou a seguir pessoas das redondezas que se deslocavam para trabalhar ou fazer negócios, marcando o caminho, os pontos de referência e fazendo o mesmo no percurso de volta. Nunca quis andar de ônibus, só anda a pé e hoje conhece e circula por todas as ruas do centro da cidade e de alguns bairros próximos.

Seu senso de pertencimento o autoriza a uma espécie de "controle" do que acontece no bairro, demonstrando também o seu sentimento pelo lugar e, talvez, a necessidade de se sentir "igual" aos demais do bairro, reprimindo o que não agrada a maioria dos seus moradores. Os policiais são seus interlocutores (e amigos) em várias situações em que sente que o seu espaço mais familiar está "ameaçado" por situações não gratas: ele vem aqui no orelhão e liga pra polícia por qualquer coisa, dizem Sabiá, Jairo, Romilda. Mas Beija-Flor reconhece bem as situações que ameaçam os bons costumes do bairro como, por exemplo: puxar fumo e roubar. Uma vez, sentindo o cheiro de maconha na minha presença disse: sente só, isso é um 
desrespeito com a senhora e saiu reclamando e caminhando rapidamente em direção ao telefone público para avisar a polícia.

Acompanhar a rotina do bairro, estabelecendo o que pode ou não ser tolerado, fazendo a mediação com o poder local, encarregado de manter a ordem e de cuidar da segurança, são imagens recorrentes da trajetória de Beija-Flor, mesmo que muitas vezes a repetição desses gestos não sejam levados em consideração: os policiais nem ligam mais, diz Jairo. Além disso, ele tornou-se também uma espécie de mensageiro de notícias ou acontecimentos da cidade, ou da vizinhança. Leva e traz notícias sobre doentes, por exemplo, como me trouxe recentemente notícias de dona Jussara (moradora do bairro que freqüentava o Caps com ele).

A rua e diferentes espaços da cidade são cenários que fazem emergir significados de maneira a concretizar, na realidade ou na imaginação, o sonho do rapaz conquistador, esperto, que leva vantagens, que não é cerceado por ninguém, ou quando é tolhido ele constrói novos cenários já que a rua oferece inúmeras possibilidades, se não vejamos:

\begin{abstract}
Uma menina é abordada por um policial, provavelmente como suspeita de algo ilicito (segundo Beija-Flor, suspeita de portar droga). Ele assiste a cena, espera o policial afastar-se, defendea, dizendo que sabe que ela é inocente, embora não a conheça. Pede a ela que o chame se necessário e a tranqüiliza sobre os policiais sob 0 argumento de que são seus amigos. Vai até 0 policial, aperta-lhe a mão, cria a cena e arranca dele um sinal de "cara legal, amigo". Remonta o cenário, passando pelo "mocinho". Ela entra no ônibus, ele me vê e diz: eu tava protegendo a menina, ela precisava...
\end{abstract}

Pelas observações e pelas conversas pude perceber que alguns percursos eram bastante evidentes como indicam alguns recortes de meu diário de campo:

Já consigo delimitar alguns marcos do percurso de Beija-Flor. Ele próprio fala que tem "batido ponto" na entrada, recreio e saída dos colégios pra ver menina bonita. Fala que de manhã é melhor porque as meninas são maiores.

Há outros motivos. Disse-me que ia ao colégio onde estuda uma prima para defendê-la de pretenso namorado, segundo Beija-Flor, não desejado pela mãe da menina: então vou lá ver e se precisar, vou executar. Executar é dar um susto, fazer ele largar do pé dela. 


\begin{abstract}
Mais sintonizada com seus horários procuro localizá-lo no seu percurso. Pouco depois das sete horas da manhã ele já está caminhando na calçada que contorna o colégio do bairro. Próximo ao portão, fala com o policial que fica na entrada da escola, coloca-se ao seu lado e fica por alguns minutos parado observando a entrada dos alunos. Observo que entrega um papel ao policial, saindo em seguida em direção à residência da familia. Estava na hora do café da manhã.
\end{abstract}

Suas passagens por esses lugares são rápidas o suficiente para olhar as meninas e não dar muito na vista para não sofrer desafetos. Próximo ao horário de saida do colégio, encontrei-o novamente, dizendo que era ajudante do sargento $F$. Quando perguntei-lhe como era ser ajudante do sargento, ele me respondeu: eu fico controlando, né. Controlando pra ninguém se passar! Eu levo palavra-cruzada pro sargento e ele me deixa ficar lá no portão do colégio.

Conversando com Beija-Flor entendi que o papel (com palavrascruzadas) que ele havia entregado ao policial dias antes fazia parte de uma negociação, uma estratégia para poder freqüentar e permanecer alguns instantes naquele local, conferindo-Ihe certa tranqüilidade para observar as meninas ficar protegido de "brincadeiras" ou comentários desagradáveis (dos meninos) e, sentir-se, pelo menos, por alguns momentos, membro integrante daquela "comunidade".

O "evento" namoro faz parte de seu repertório. Embora sempre mencione que está com alguma namorada - tô voltando da casa da namorada, agora tô amando, mas o pai dela não quer que nós namoremos , não leva $O$ assunto adiante, nem dá maiores detalhes. $O$ que pudemos captar foi que o namoro, suas andanças para ver as meninas, expressa ainda uma necessidade de sentir-se homem frente aos outros (homens e mulheres) em um universo em que a honra masculina também está relacionada à capacidade de namorar, casar, constituir família. O papel desenvolvido pelo nosso protagonista evidencia o seu investimento em torno de uma "figura" masculina que, no seu universo cultural, tem uma função a desempenhar em relação às mulheres. Distante de outros espaços sociais vividos pelos homens, como o dos bares, dos jogos ou do trabalho formal 
que the possibilitaria outros vínculos sociais, a rua, torna-se o principal território de expressão e expectativas acerca de práticas e significados que dizem respeito ao compartilhamento de códigos e valores sociais e culturais.

A necessidade de um modo de existência masculino identificado com o local vai conectando-lhe a outros espaços:

A "oficina" a que Beija-Flor se refere é uma revenda de automóveis. Sempre atento aos modelos de carro, ele encontrou um local em que pode ver de perto os modelos colocados à venda, tocar, conhecer os acessórios de cada um e até entrar nos carros que, normalmente, só vê à distância.

O seu cotidiano é também perpassado por cenários do centro da cidade, como as vitrines da rua Moron e os camelôs, onde ele tem alguma autonomia para comprar objetos próprios: o "rayban", o relógio, ou as luvas para o inverno. Outras compras são feitas pela mãe, mas algumas peças são escolhidas por ele, como é o caso dos tênis. Ele faz um levantamento de preços nas lojas do centro, leva os bilhetes com tudo anotado para sua mãe que efetiva a compra. Segundo ela, Beija-Flor não conhece bem dinheiro, sendo facilmente enganado (mostrou-me um par de luvas que comprou, com as duas mãos esquerdas). As compras menores ele mesmo faz. Esse "pequeno gerenciamento" deixa para os adornos que thes conferem características visuais semelhantes ao 'boy' contemporâneo.

Com as férias colegiais e a inauguração de um posto de gasolina e loja de conveniência no bairro, ele também deslocou sua atenção para esse novo atrativo, local disputado pelos jovens nos finais de tarde e à noite, passando a freqüentá-lo. Sua aproximação e recorrência ao local possibilitou-lhe "cavar" um lugar de ajudante, distribuindo propaganda e fazendo a divulgação. Eu mesmo sou uma freguesa em potencial: a senhora que sempre anda de carro, quando precisar abastecer vai lá abastecer que eles têm um preço especial, eles são meus amigos. Sua moeda de troca é a possibilidade de permanecer, pertencer, ir e voltar quantas vezes quiser, sentindo-se parte, tendo um lugar em que é aceito. A doação por parte do posto de um "uniforme" (camiseta e boné), é motivo de muito orgulho, fortalecendo o sentimento de pertencimento e de fortalecimento de um oficio de valor.

\section{- Tô liberado!}

Essa era outra frase de entrada quando nos encontrávamos. Assim como o namoro, o trabalho do qual se dizia liberado, naquele dia, não era explicitado facilmente por ele. Nos comentários de familiares, percebia uma certa ironia sempre que esse assunto voltava. Na verdade, não reconheciam que o trabalho que realizava tratava-se de um trabalho no sentido capitalista 
do termo. A mãe dizia: ele às vezes ajuda uma mulher, mas ela dá centavos que não valem quase nada.

Beija-Flor recebe pensão mensal pela sua condição de doente, mas como tem uma curadora, não gerencia o seu dinheiro. Esse processo parece-lhe confuso, embora saiba que, através dele, consegue um recurso importante para ajudar na manutenção da família. Conhece o dinheiro, mas confunde-se com facilidade, principalmente se tiver que 'fazer troco', fato pelo qual não pode ter dinheiro na mão, conforme relatou sua mãe. Portanto, não é o valor-dinheiro que importa a Beija-Flor, mas o valor simbólico de uma prática de fundamental importância cultural na constituição da condição humana e da sua singularidade de sujeito.

Falando sobre o que faz, enfatiza: eu trabalho de office-boy, sou office-boy, essa é a minha profissão. Nada mais adequado do que aliar uma profissão com o seu gosto de andar na rua e com a possibilidade de criar as próprias regras. Ao percorrer sua trajetória descobri que ele realizava atividades regulares para uma senhora do bairro. Já havia me falado várias vezes sobre isto, mas como sempre, sem maiores detalhes. Nos diários abaixo registro fragmentos dessa trajetória:

Nesse dia chamou-me atenção uma atitude de Beija-Flor. Ele bateu à porta de uma casa localizada próxima a uma pequena praça. Observei que ficou aguardando, mas ninguém atendeu. Ele me disse mais tarde que fora à casa da mulher para quem trabalha, mas que ela não estava em casa.

Beija-Flor disse que estava chateado porque naquele dia não tinha conseguido nada. Novamente ele se referia ao trabalho. Ele faz um jogo de meias palavras, de modo a nunca deixar muito claro a que se refere, mas quando pergunto ele responde: só comprei uns ovos prá senhora que eu trabalho, mas tô por aí, tô ligado! Questiono como é o trabalho e ele diz: eu compro no mercado e levo pra casa, ou só carrego também, depende dela.

Depois de vários encontros em que Beija-Flor me dizia estar "liberado", pude encontrá-lo no exercicio do seu trabalho. Apressado avisou-me: agora não posso falar contigo dona Bernadete, tenho que ir. Preciso levar essas compras pra dona Mariana fazer o almoço. Ao observar a direção vi que se tratava da mesma pessoa.

Vi-o conversando com um vizinho, perto de sua casa. Foi ao meu encontro e contou-me que estava indo lá na casa de Mariana (a mulher para quem trabalha), porque ela o havia dispensado, o que o deixou irritado, levando-o a discutir com ela. Entretanto, 
depois de se acalmar, embora ainda chateado, iria até a casa da senhora para tentar consertar o que fizera, pois não tô pra dispensar trabalho, tenho minha mãe pra sustentar, sabe...

Novamente na rua, vejo Beija-Flor andando em direção ao mercado. Observei que entrou, foi direto à prateleira do açúcar, pegou um pacote e foi ao caixa, cumprimentou a funcionária, pagou, guardou o troco e saiu rápido em direção à casa da senhora para quem trabalhava. Era um sinal que havia conseguido as "desculpas" de dona Mariana. Na seqüência fui ao mesmo caixa e ouvi o comentário da moça do caixa com a colega ao lado, dizendo-lhe que aquele rapaz ia com freqüência para comprar um só produto. A resposta foi: pelo menos ele se entretém com alguma coisa. Sinto um clima de piedade e tolerância. Seria de fato um entretenimento para o Beija-Flor?

Na saída faço o seu percurso e vejo-o voltando da casa de sua empregadora. De longe me avista e grita: oi, quando vai lá em casa? Contou-me que tinha ido trabalhar, mas já estava de folga.

O trabalho desenvolvido por Beija-Flor tem um sentido profundo, distante de qualquer idéia de entretenimento empregada pelas funcionárias do mercado. Trata-se de um lugar social, construído por ele, com regras, deveres e direitos que mais do que o reconhecimento efetivo de uma atividade produtiva, possibilita-Ihe a convivência, a troca, enfim, um associarse aos códigos do seu contexto.

Entendo que para ele, ir ao mercado, não é apenas trocar dinheiro por produtos, mas, tem um capital simbólico importante. É o efeito de um consenso, de um "acordo tácito" (nos termos de Certeau) entre a senhora que Ihe dá o trabalho, Beija-Flor e os funcionários do mercado. Isso dá uma dimensão do quanto o espaço da cidade, ainda que tenha problemas, é espaço privilegiado para a inclusão e o acolhimento.

Em outros cenários registro aspectos que reforçam a necessidade de afirmação e identificação pelo trabalho:

No inicio da tarde encontrei Beija-Flor que andava rápido com seus óculos escuros e, naquele dia, com mais um adorno: uma pasta tipo "executivo", uma cena que associada a outros fragmentos é carregada de material simbólico. Era o horário em que os "trabalhadores" estavam saindo de suas casas para o comércio, as fábricas, as escolas,... Era o tempo do trabalho. 
Contrariamente à visão de seus familiares (mãe e irmãos) de que a rua é lugar de perigo, para o Beija-Flor a rua é o espaço de liberdade, um dos locais onde constrói sua auto-imagem, cria possibilidade de desempenhar papéis sociais fundamentais para um homem da sua idade, com novas chances de expressão, mesmo, nos termos de Pitta (2001, p.12) "tendo o estigma como substrato de suas atuações, mas agindo apesar dele". 


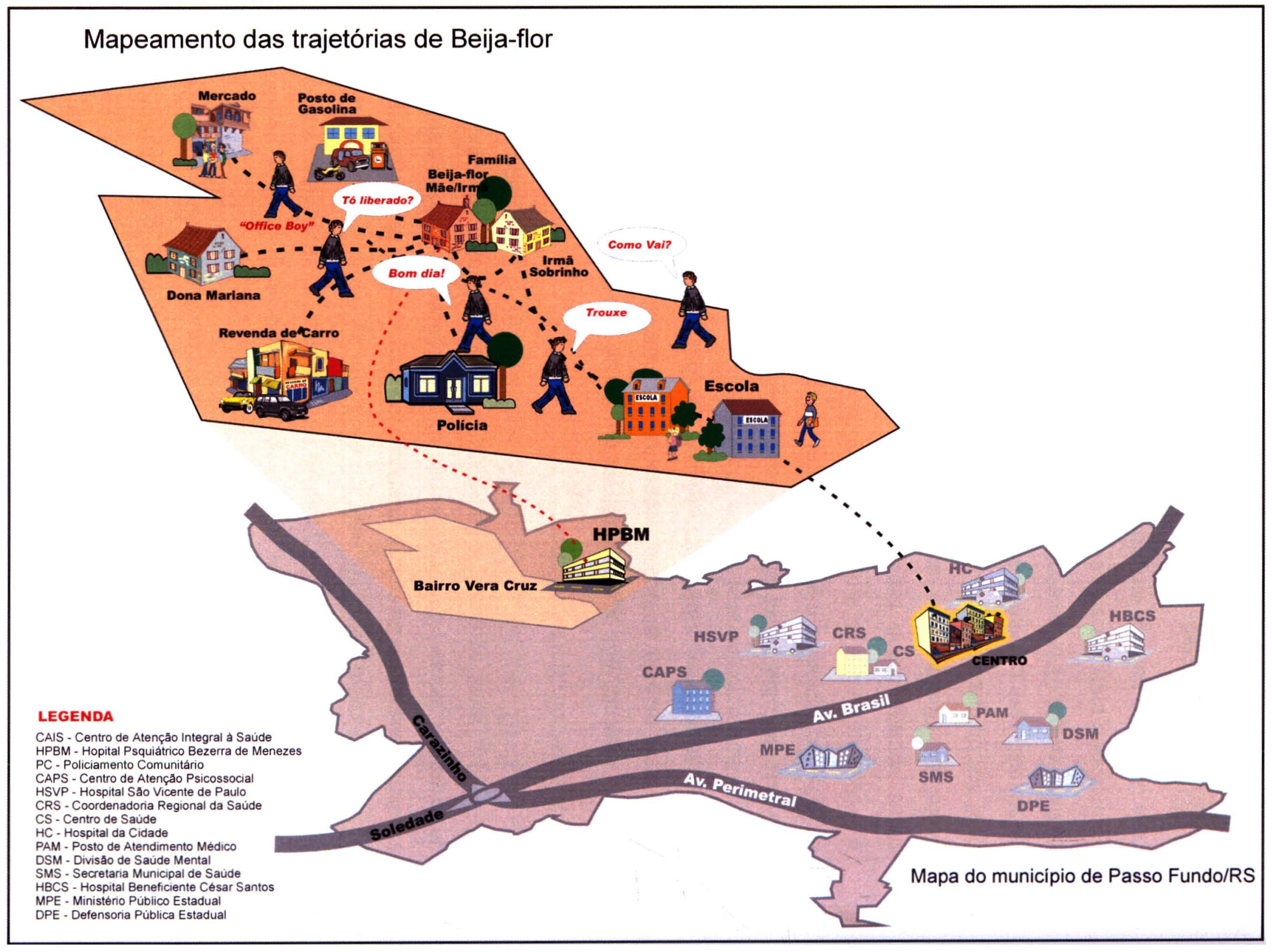




\subsubsection{Entre a casa e seus interlocutores imaginários}

A fala restrita de Pomba-Rola, a circulação em torno das mesmas questões prevalece no seu repertório e parecem ser as "motivações" que the dão algum alento à vida. Uma história que aparenta estar "congelada" há 15 anos. A cartomante, o ex-namorado, seus risos inesperados, o incômodo com sua beleza: sou feia! Porque preciso de psicóloga? Diz que Passo Fundo é ruim porque não tem firma que pega a gente pra trabalhar. Perguntei-Ihe se gostaria de trabalhar fora, ao que me respondeu: não, não gosto de trabalhar nem fora, nem em casa, sou aposentada, aposentada por invalidez, por causa da minha doença. Nos últimos tempos incorporou mais um elemento ao seu universo: a mãe tá com câncer, ela pode morrer! Mas não se fixa nessa situação, volta ao seu itinerário particular. Nos períodos de internação da mãe vai ao hospital por insistência do pai, mas não consegue permanecer alí por muito tempo.

Percebi nas sucessivas visitas a sua casa que, apesar de sua resistência, os pais, ambos aposentados, procuravam se organizar dentro de suas possibilidades para envolvê-la no convivio social. A sua sociabilidade está profundamente vinculada ao modo de vida e as tradições da familia que mantém do meio rural algumas particularidades. São vivências e laços criados com vizinhos, parentes e compadres, através da visita em sua casa, das idas semanais à igreja, que são fundamentais para alimentar essas redes sociais. Estão sempre the oferecendo oportunidades de melhoria como quando the deram uma bicicleta ergométrica para pedalar, já que não quer sair de casa e precisa baixar de peso. $O$ pai chegou a estudar os sinais de trânsito com um neto para tirar a carta de motorista e comprar um fusca, assim levaria Pomba-Rola para fazer uns passeios, processo que interrompeu para esperar o tratamento de um câncer que se manifestou na mãe durante o período em que eu realizava a pesquisa de campo.

Sinto a preocupação da mãe (agora debilitada pela doença) em delegar ao marido algumas de suas funções, como the dar o remédio, pois, segundo eles, ela se atrapalha para tomar sozinha: não toma ou, toma duas 
vezes e, levá-la ao psiquiatra mensalmente. O cuidado com casa e alimentação também ficaram por conta do pai com o apoio eventual da sobrinha que mora nos fundos. Nesse particular, a Pomba-Rola tem sido "convidada" a participar. Tenho observado uma cobrança por parte da família, particularmente dos que não vivem diariamente com ela, para que assuma a casa. Falou-me que não faz nada e que as tias têm dito que ela precisa limpar a casa, realizar os afazeres domésticos, mas não parece ser o seu desejo, embora tenho observado que realiza tarefas quando solicitada: arrumar a mesa, varrer a casa, lavar alguma roupa, a louça e até participar da "roda" de chimarrão para acolher as visitas de sua mãe.

Nas diferentes falas e relações, percebi que constantes manifestações dos papéis esperados para homens e mulheres emergiam de um modo específico na família e na vida de Pomba-Rola e anunciavam prescrições para a mulher. Registro em todos os nossos encontros, elementos que convergem para assuntos como o namoro, o casamento, a beleza, a constituição de família, o cuidado com as tarefas domésticas, dos pais, dos filhos. Esse parece ser também o campo que permite maior interlocução e estímulo, tanto para ela como para os seus familiares.

Suas irmãs já seguiram o curso normal da vida, tantas vezes definido como o casamento, a constituição de suas familias, suas casas, arrumaram trabalho e administram suas próprias vidas. Para os seus pais, o alívio ainda vem da possibilidade de exercerem seus papéis de provedores, conforme verbaliza o Sr. Avelino: graças a Deus estamos aqui com ela e somos os três aposentados, então pelo menos, ela também recebe um recurso. Ter "um recurso a mais" da sua aposentadoria é uma compensação diante da expectativa frustrada da filha que deveria ter constituido família e, pela "ordem natural" da cultura local, ajudar no cuidado dos pais.

A vivência de um sofrimento limitador traz o fracasso desse papel acionado em diferentes momentos, tanto na solicitação de ajuda e mudança dos papeis da casa com a doença da mãe, como nas brincadeiras com pessoas conhecidas que poderiam ser seus pretendentes, ou, no repertório 
construído antes do adoecimento e que não se apaga do seu imaginário (afinal era o esperado por todos). Esses últimos, hoje interlocutores distantes - a cartomante e o ex-namorado - mesclam-se às dúvidas deixadas por tantas modificações - eu sou mulher? Acho que não sou mulher! - com o seu corpo que já não tem as mesmas formas de outrora: eu já fui bonita, agora sou feia! Enfim, um inventário de impossibilidades, de incapacidades diante de papéis definidos para uma mulher naquele contexto.

Fiz algumas tentativas durante a pesquisa para tirá-la de dentro de casa, mas só consegui, depois de muita insistência, dar uma volta nas imediações do terreno: Bernadete eu tô bem aqui, eu não quero sair. Parece que $o$ isolamento desses anos todos exige um trabalho bem mais intenso e persistente para fazer Pomba-Rola encontrar outros interlocutores que the dêem sentido e outras motivações para sua existência. 


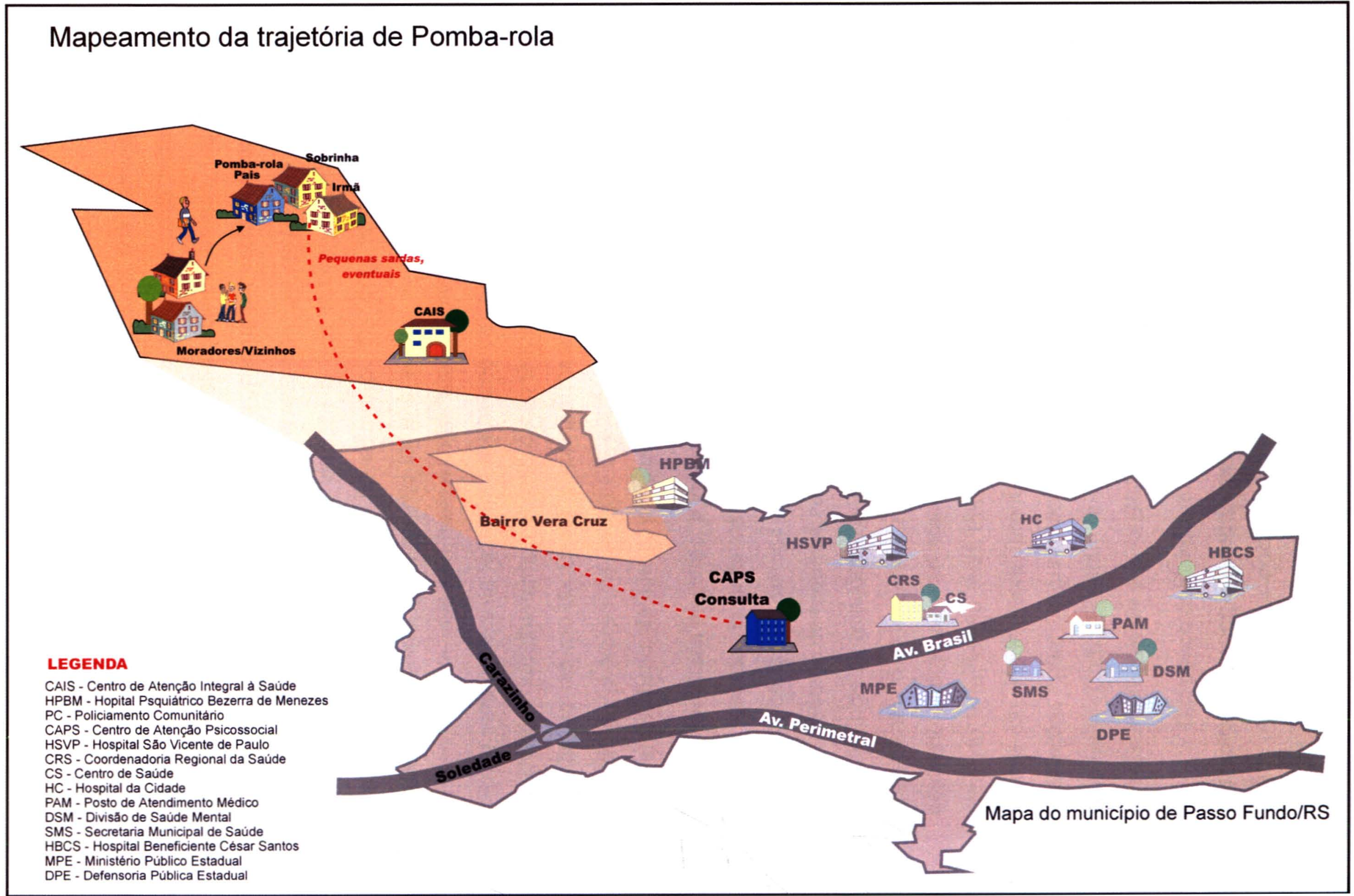




\subsubsection{A crise e as referências do território}

No retorno da internação, e com a melhora "dos pensamentos que Ihe atentavam", a trajetória de Sabiá dá sinais de outras marcas que o paralisaram: eram as perdas das suas referências - amigos, trabalho, vida social, etc. $O$ bairro parecia ser outro: o pessoal conhecido casou, constituiu familia, outros sairam para trabalhar. Não se sabe se por razões relacionadas a ele ou não, a verdade é que houve uma debandada da familia por ocasião do seu adoecimento. Os dois irmãos mudaram-se, deixando as casas ao fundo do terreno vazias. A cunhada me disse que tinha medo dele, por isso, sempre que Sabiá ficava mal, ela ia com a filha criança para a casa da mãe em uma cidade vizinha. De fato, ela, a filha e o marido que trabalha como pedreiro e não têm moradia fixa; mudaram-se por ocasião do retorno de Sabiá e eu não mais os encontrei, durante todo o período da pesquisa de campo. O outro irmão, saiu de "férias" para Porto Alegre, e lá ficou, de janeiro a maio.

Em meus registros, a imagem de Sabiá era a de um sujeito solitário, sempre sentado no pátio da casa. A sensação era a de alguém que vivia uma ressaca resultante dos acontecimentos recorrentes no período em que esteve afastado de todos os seus, situação que se voltava contra ele próprio - abstinência de relações - e, a espera de alguém que pudesse sintonizá-lo, novamente, com um tempo já passado. A situação vivida pela crise e o desfecho que o levou ao afastamento físico e existencial, desconectou-o do contexto e restringiu suas trocas com a família e os amigos do local. Nos termos de Morin, poderiamos dizer que não escapou da entropia das instituições que, seguramente, corroboraram imensamente com esse

processo. Com Guattari e Rolnik, podemos dizer que houve um desmanchamento de seu território psicossocial, uma desterritorialização.

Um pouco nostálgico trazia, do seu passado recente, as lembranças das saidas para jogar futebol, para ir à cidade, nos bares e bailes ou, para reunir os amigos no porão de sua casa (que mesmo sem a visita dos amigos, continuava a limpar): a gente botava música, cantava, tomava 
cerveja e enchia ali. Contava sempre com a companhia dos guris aqui da volta e com os meus irmãos (Sérgio e o Luiz). Durante a semana, trabalhava como auxiliar de pedreiro com os irmãos que empreitavam obras, ou descarregava os caminhões de material de construção do filho do seu Jairo da bodega.

Em casa, partilhava com a mãe algumas atividades como, ver televisão (as novelas e filmes da Tv Globo), tomar chimarrão e "virar" a terra aos fundos do terreno para plantar alguma hortaliça. Nos primeiros meses após o retorno, as conversas giravam em torno da "sua doença".

Nesse periodo, suas interações mais intensas fora da família eram com o Jairo que continuou com a responsabilidade que assumira no período da internação. Se não vejamos: de volta para casa, a orientação era a de não abandonar o remédio, e ele que não tinha seguido essa orientação nas outras internações, agora estava disposto a não interromper o tratamento. É nessa relação que percebo suas dificuldades iniciais bem como os arranjos realizados pelo Jairo - conseguir o remédio sem levá-lo para consulta, sem esperar na fila, ou mesmo, conseguir alguns comprimidos na farmácia sem a receita. Muito embora esses arranjos tenham-no ajudado, também contribuíram para reforçar em Sabiá uma forte relação de dependência, dificultando que ele assumisse as questões que thes diziam diretamente respeito. É o que se depreende desta sua fala: ainda bem que tem ele, porque a gente não sabe, não conhece. Não sei o que dizer pro médico, é sempre ele que fala o que eu tenho.

Assim, a imobilização que o tomou, quando de seu retorno do hospital, e os "arranjos" do Jairo acabavam por contribuir para que Sabiá não fizesse o "caminho" por conta própria, pois eram negociações muito distantes para um "despossuido".

Sempre bem arrumado, embora dissesse que estava enjoado de estar só dentro de casa, não se animava a sair sozinho. Demonstra respeito por João (seu irmão), mas não vê nele um companheiro, pois o irmão já tem seu itinerário próprio. Sabiá lembra que o irmão não era assim antes de ser 
assaltado e esfaqueado e que já trabalhou bastante, mas agora passa os dias fazendo jogo de loteria, faz pilhas e pilhas de cartões e, na segunda feira, escolhe um e aposta. Então vai para o centro (da cidade) uma vez, duas por semana, mas direto nas casas lotéricas, é só o que ele gosta. Eu não entendo os cálculos dele, passa o dia inteiro fazendo cálculo. João, que trabalha incessantemente nos seus jogos, fala sozinho e sem parar sobre o assunto que estamos conversando. Às vezes se aproxima e faz um comentário: eu já ganhei várias vezes na loteria, mas não os cartões que eu aposto. Me dá muito trabalho, mas eu sempre consigo acertar, inclusive tô falando rápido contigo porque tenho que voltar a fazer os cálculos, senão eu não consigo terminar. E assim ele passa os dias. Sabiá lembra que João é o único que não sofre com as questões econômicas familiares porque, ao menos em sua imaginação, tem bastante dinheiro no banco.

Todas as vezes em que estive lá e a mãe estava ausente (ela é faxineira), Sabiá justificava-se: não vou te convidar prá entrar porque estamos só eu e João em casa. Então, pegava uma cadeira da cozinha e colocava-a no pátio. Entendi que essa era uma questão de respeito comigo e uma regra da casa, ou seja, na ausência da mãe, não poderiam convidar mulher para entrar, mas no pátio, não havia problemas, já que era em lugar aberto, com vista para a rua e para os vizinhos.

Apesar de todas as agruras que o afastamento advindo das internações tinham lhe trazido, Sabiá mantinha a esperança e o desejo de recomposição de seu território psicossocial. Foi desfrutando do apoio inicial da familia de Jairo, ajudando eventualmente nas descargas dos caminhões de material de construção, que ele foi resgatando timidamente relações anteriores. Com a chegada do inverno - muito esperado por Sabiá, pois seus irmãos não haviam levado as roupas quentes e nem outros pertences seus irmãos retornaram. Sérgio, que estava em Porto Alegre, retornou para morar na casa que havia ficado vazia e Luiz para visitar a família.

O reencontro com os irmãos trouxe-lhe novo alento, aumentando suas conexões com o mundo que haviam sido interceptadas pelo processo 
de adoecimento, oxigenando sua vida, permitindo a retomada do sentido e do rumo de sua existência. Passei a encontrá-lo, brincando com o sobrinho de quatro anos, saindo para a rua em locais diferentes acompanhado do irmão, numa relação muito afetiva. Agora eu fico mais com ele, não ando mais triste, perdido. Eu fico mais na casa dele, conversando e ouvindo hino (o irmão freqüenta a igreja Evangélica e também compõe, canta e toca violão), saio sempre com ele que tem lidado com as músicas e a igreja. Ele já gravou dois $C D$ s. A religião parece não atrai-lo, mas respeita o irmão que também o respeita. Diz que não vai à Igreja porque demora muito e dá sono, mas se sociabiliza a partir dessa prática, participando dos ensaios, gravando as músicas juntamente com o irmão. $O$ cuidado com a assistência a saúde, antes assumida e "negociada" pelo Jairo, também passou a ser assumida pelo irmão que, juntamente com Sabiá, faz mensalmente o percurso para a consulta e a busca do remédio.

Dona Rosalina, a mãe, sonha que os três filhos possam voltar a trabalhar juntos: ai o Sabiá pode trabalhar mais no chão, no serviço mais leve enquanto tiver que tomar esses remédios fortes. Para Sabiá a possibilidade é voltar a trabalhar "de ajudante", já que ele não tem estudo (fez até a $4^{\mathrm{a}}$ série) e não tem outra profissão. 
Mapeamento das trajetórias de Sabiá

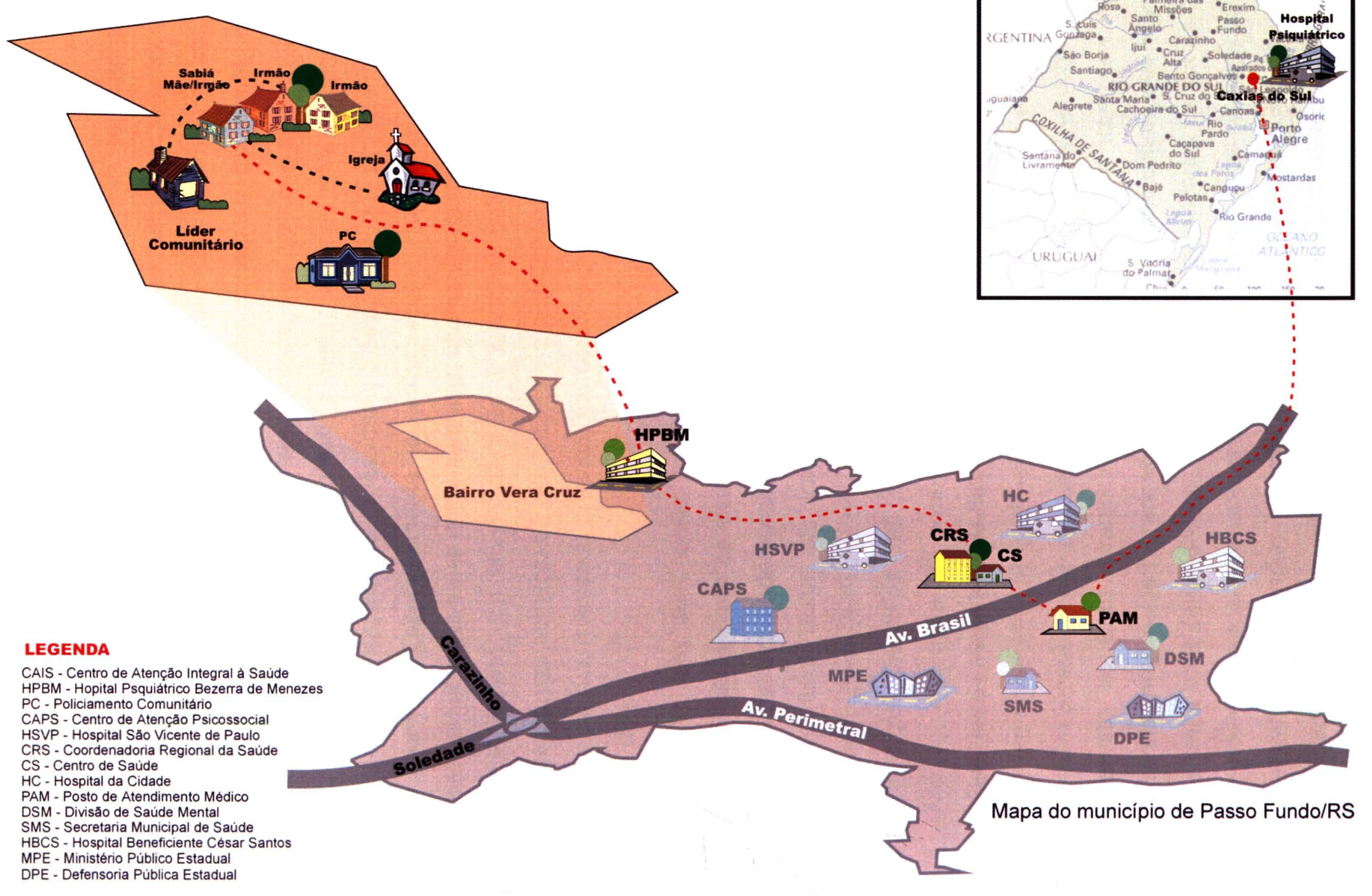




\subsubsection{Um link com os de fora}

Bem-Te-Vi que passa todo o dia no Caps, não se deixa passar desapercebido por ninguém de fora (aqui me refiro a conhecidos não usuários do Caps) que chega nesse lugar. Ao me ver, envereda com seu passo comprido, seu sorriso expressivo para me dar seu tradicional beijo no rosto e dizer, como se procurasse exercitar sua memória: Bernadete! Fica atento aos movimentos de entrada e saída, correndo para recepcionar as visitas, particularmente os profissionais e estagiários que vão eventualmente ao serviço. Especificamente à enfermagem, que realiza atividades acadêmicas nesse local, dirige-se a elas, chamando-as de minhas joinhas. $O$ grande rodízio dos alunos ali, não é problema para ele; ao contrário, representa um aumento do seu circuito e a possibilidade de encontrar esses alunos na rua, mantendo presente na memória o nome de vários deles por longa data.

O fato dele morar em uma pensão é motivo de recorrentes comentários da parte da vizinhança, que tem dificuldade em compreender, porque uma familia de posses como a do Bem-Te-Vi, faz isso com um dos seus membros. Sobre isto, Iradi, um vizinho, diz: pois é, eu não entendo a família do Bem-Te-Vi. Ele tem uns irmãos que podem (financeiramente), dá pra ver pelo carrão da irmã que vem ai uma vez por mês pagar a Nádia. Seu Antonio, que mora um pouco mais distante, caminhando comigo na rua disse: essas terras são da familia do Bem-Te-Vi, eles tinham bastante terra, tem um irmão que mora aí em cima e eu acho que é dono de tudo. Tem também uma irmã que é doutora, mas não aqui. Eu não acho certo eles o deixarem lá. Esse arranjo feito pela familia é visto com um certo estranhamento pelos moradores do bairro que não concebem que alguém que tenha boas condições econômicas transfira os cuidados de um parente tão próximo para uma pessoa estranha. Algo compreensivel se resgatarmos a constelação familiar desse bairro, que, conforme descrevemos anteriormente, mantém valores e tradições do meio rural, onde a familia tem um valor fundamental. Bem-Te-Vi raramente faz referência à familia 
biológica. Quando precisa de alguma coisa dirige-se à Nádia que é sua porta-voz, inclusive nas representações festivas, como as festas do Caps (Natal, aniversários,...).

Nádia que cuida do Bem-Te-Vi há cinco anos diz que quando o conheceu tinha muito medo dele, porque sua fama era ruim. As pessoas diziam que ele era maroto com as meninas, mas a gente nunca viu nada, ele só tem esse jeito de ficar 'enticando' com alguns, assim pegando no pé, mas é só esse jeito, não tem risco, só que ele não fica quieto.

A casa de Nádia situa-se em um terreno com duas residências: uma casa mais velha na frente e uma que ainda está em construção, mas já habitada pela família. Nesta casa, o quarto do Bem-Te-Vi é separado dos demais, saindo para a sala, próxima à cozinha. Eu arrumei uma mesinha, cadeira no quarto dele e ele faz as refeições aí, separado, porque eu cuido dele, mas também quero a minha independência. Ele sabe o lugar dele. Nem água ele pega sem pedir. Ele nunca abriu a geladeira! Depois que ele veio morar comigo, as pessoas foram agarrando confiança nele. Ele não me incomoda. Eu sei das minhas obrigações e ele sabe dos limites. Faz comparação com um outro sujeito que vivia a experiência do sofrimento psíquico que também morou com ela durante um tempo, mas era muito abusado, não obedecia, pegava qualquer coisa a qualquer hora: comida, batia na geladeira, saia pra rua e eu não sabia onde, tinha que ir atrás. Eu tenho as minhas meninas também, então tem que ter regra, senão eu não agüento.

Alguns fragmentos ajudam a esclarecer a dinâmica do morar de Bem-Te-Vi:

Enquanto conversava com Nádia e suas filhas na sala, Bem-Te-Vi colocou a cabeça na porta e me disse: Bernadeteee! Do mesmo jeito de sempre quando me encontra, porém, um pouco recatado, deu-me a mão, o seu tradicional beijo no rosto e se retirou, solicitando a filha de Nádia um copo de água. A menina serviu uma caneca de água gelada e ele, sem comentário, voltou ao quarto. Pude constatar, então, o que me pareceu estar claro para ele: o seu espaço naquela casa/família. Quando fui embora, estava debruçado na janela de seu quarto, atento para se despedir. 
Num final de tarde de verão, encontrei a família que alberga BemTe-Vi sentada no pátio da casa tomando chimarrão e conversando. Ele estava em seu quarto, sozinho, havia mudado para o porão da casa velha em frente, onde antes morava o outro cunhado de Nadia. Contou-me do sucesso dos vizinhos no vestibular e dos cursos que haviam escolhido. Existem regras de sociabilidade distintas entre o Bem-Te-Vi e a vizinhança. Ele é discreto, mas sempre que vê alguém na volta para casa, acompanha os movimentos e estabelece um diálogo. As saídas ficam restritas por conta de um "contrato" de obrigações e limites que ele cumpre, ficando mais circunscrito a sua casa.

Em outras ocasiões percebi que na relação com os vizinhos ele goza de prestígio. Para Iradi, o Bem-Te-Vi faz anos que se trata, mas é bem esperto, referindo-se ao trabalho que faz nos bancos, nas lojas, inclusive para a vizinhança. As pessoas gostam dele, às vezes convidam prá jogar carta, assistir jogo, particularmente do grêmio (do qual é torcedor), passear na casa delas. No fim de semana, sábado ou domingo, ele tira pra passear, vai à casa da irmã ou, na dos parentes que moram aqui na cidade.

Durante minhas observações, passei a encontrá-lo no início da manhã e no meio da tarde, fazendo o percurso de ônibus nos mesmos horários. Queria saber porque entrava pela porta da frente do ônibus se não tinha idade para isso. Descobri que um vizinho o orientou para que entrasse pela porta da frente com a carteira de identidade na mão e, caso o motorista não aceitasse, fizesse o procedimento normal. Depois das primeiras vezes, os motoristas passaram a aceitá-lo regularmente: eu economizo uns troquinhos, já que a prefeitura não mantém com regularidade o passe livre para os freqüentadores do Caps.

A principal caracteristica de Bem-Te-Vi é a necessidade de trocas com o "fora": realizar trabalhos para o serviço de saúde - sou o office boy oficial do Caps ${ }^{62}$-, para sua locatária e para os vizinhos, além de

\footnotetext{
${ }^{62}$ Embora entenda como fundamental a discussão por parte dos serviços sobre o desenvolvimento de "projetos de trabalho", não analisarei essa prática por esse viés. A associação entre trabalho e tratamento em serviços de saúde mental é histórica. Os doentes mentais das instituições psiquiátricas, desde muito tempo, foram "postos a trabalhar" em colônias agrícolas e outras atividades diversas. Nesse percurso histórico, o trabalho ocupou um lugar de tratamento e de adaptação social, com um cunho moral, de recuperação da disciplina e, por vezes, de ocupação do tempo. Via de regra, um trabalho não reconhecido, passivo, não pago, escravo e, muitas vezes, infantilizado. Diferentemente
} 
recepcionar a todos os "de fora" que chegam no serviço onde passa seu dia. Ele está sempre com o "radar" ligado, captando as conversas e fazendo comentários. Inventa apelidos e charadas, motivo de freqüentes atritos com os colegas, tornando sua relação no serviço de saúde, por vezes conflituosa, fazendo-o retornar mais cedo para casa como registra Nádia: hoje ele veio cedo do Caps, deve ter aprontado alguma, veio quieto, tomou um banho, almoçou e foi dormir.

No transcurso da pesquisa registro cenas recorrentes de nosso protagonista caminhando ereto, devagar, com cuidado para atravessar as ruas e atento às pessoas que passavam:

Hoje carregava envelopes. A distância fui observando parte de seu percurso. Encontrei-o nas proximidades da Secretaria de Saúde. Embora não esperasse me encontrar, fui uma de suas homenageadas naquele dia. Recebi um cartão artesanal confeccionado nas oficinas do Caps, contendo uma mensagem do serviço às mulheres por ocasião do dia oito de março. Nas repartições da Secretaria cumprimentou as pessoas, recebeu agradecimentos, trocou palavras de forma cordial. Daí seguiu para o Posto de Atendimento Médico e para a Coordenadoria de Saúde.

Um momento de muita alegria para Bem-Te-Vi concretizou-se no dia em que acompanhou uma profissional, reconhecida no nosso Estado e no Brasil pela sua militância na saúde mental, e que esteve em um evento organizado pelo Caps. No mesmo carro que a conduzia até o local do evento ele foi falando da cidade: hoje eu fui o guia turístico da Sandra Fagundes, fui mostrando os pontos turísticos e ensinando o caminho.

O momento da rua é permeado de sentidos e o fascina pela sua porosidade, pelo espaço de abertura para o exterior, onde reencontra a possibilidade de produzir obras, valor social e liberdade, buscando também um encontro com seu passado no "trabalho nos caminhões". Retomando a idéia de Morin, a complexidade está nas múltiplas interações e composições construídas no cotidiano, inclusive onde não se pode vencer as contradições. A própria autonomia, alimenta-se da dependência; dependemos de uma educação, de uma linguagem, de uma cultura, de uma como "um instrumento de inclusão do sujeito no mundo das contratualidades sociais". 
sociedade (MORIN, 1990, p.96) que, por vezes, inibe e empobrece o desenvolvimento humano.

Sua trajetória me reporta à importância do tecido que se tece junto, ou seja, as evidências mostradas por Bem-Te-Vi, acredito, permitem perceber um importante diferencial quando o serviço de saúde (no caso, o Caps) consegue captar e investir em um projeto pautado nas necessidades e potencialidades do sujeito no seu contexto, no contexto da cidade. Seguramente, essa expansão com o "fora" é um dos ingredientes fundamentais do seu itinerário terapêutico, possibilitando-Ihe um aumento de repertório, de autonomia, de investimento em relações interpessoais, enfim, de enriquecimento de sua subjetividade.

Bem-Te-Vi, assim como os demais protagonistas, me permitiram constatar a relevância do espaço público em suas vidas. Foi no "encontro" com determinados espaços da rua, do bairro, que identifiquei um rico campo de interações; locais que possibilitam a diversidade, onde as pessoas crescem, se desenvolvem, se relacionam, cultuam suas "raizes", exercendo uma sociabilidade bastante peculiar, baseada no prazer da conversa, do encontro com os amigos, da vivência com a vizinhança, da festa, da igreja.

Trata-se de uma via que amplia a possibilidade de inclusão, de convivência, de liberdade, de identificação com o outro não doente, de exercício de certos papéis, de se sentirem sociáveis e aceitos em espaços da cidade. Esse trânsito pela cidade vai formando uma rede de sustentação, por vezes pouco visivel, como pontos de referência para a troca de afetos, para o desenvolvimento de pequenos serviços, para o lazer, para alimentar a imaginação, enfim, suportes capazes de contrabalançar com outros aspectos do cotidiano. É também um espaço de conflitos, mas que também ajudam a construir estratégias capazes de transpor as barreiras criadas diante das suas diferenças. 
Mapeamento das trajetórias de Bem-te-vi

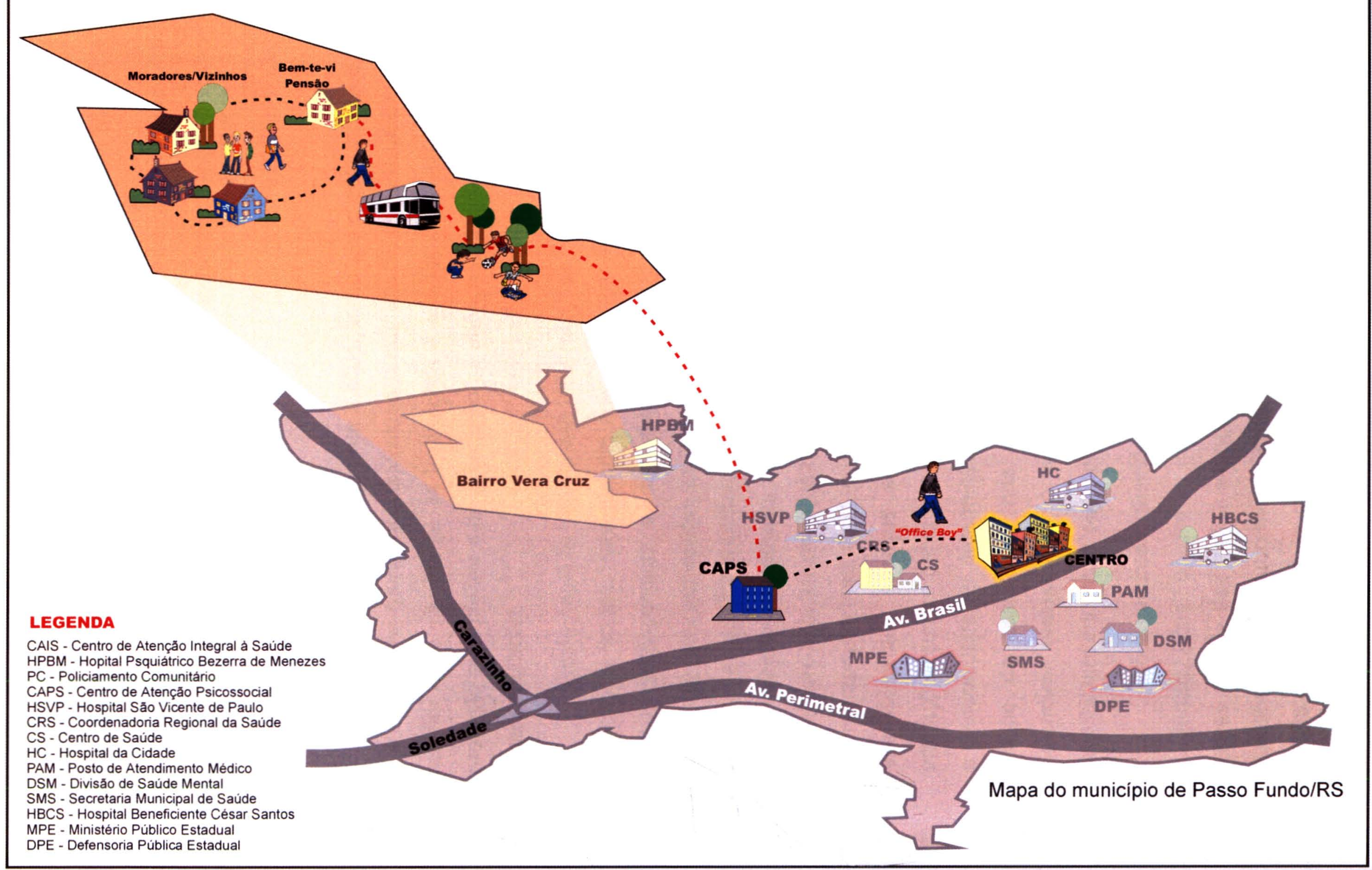




\title{
CAPÍTULO V - INTER-RELAÇÕES E TENSÕES QUE PERMEIAM O CIRCUITO DA ATENÇÃO À SAÚDE MENTAL
}

\author{
Quando alguém sente em seu corpo o efeito de campo das \\ correntes afetivas e das relações interpessoais, de imediato o \\ tachamos de histérico ou esquizofrênico, enquanto consideramos \\ normal aquele que se articula insensivel a todos os \\ automatismos...
}

(RESTREPO, 2001, p.28)

A busca de recursos para a situação de sofrimento psíquico é ampla e abrange uma gama de possibilidades que vão do suporte afetivo no âmbito familiar e de vizinhança às instituições e entidades de cunho religioso, de proteção aos direitos e de prestação de serviços de saúde, específicos para essa população.

Neste capitulo tratarei das inter-relações que permeiam o circuito de atenção à saúde, ressaltando sua presença marcante no cotidiano de nossos protagonistas $e$, também, as marcas que essas inter-relações imprimem aos sofredores psíquicos. A recorrência a este circuito fez-nos perceber as particularidades do ingresso dos sujeitos nos serviços de saúde, as diversas formas de uso, além de arranjos e estratégias que se constroem nesse percurso. Mesmo que o nosso universo de pesquisa refira-se apenas a uma ou outra instituição, é importante lembrar que a busca e a recorrência aos diferentes espaços se constituem no resultado do conjunto das interações que se constroem na esfera social. Se, por um lado, registramos a generalidade de determinadas tramas que se reproduzem e dominam o campo da assistência nos diferentes espaços; por outro, é possível vislumbrar, timidamente, é verdade, algumas negociações e espaços que possibilitam encontros para as singularidades.

Aqui, algumas questões inicialmente nebulosas, tornaram-se mais evidentes. Afinal, porque os nossos protagonistas desempenhavam bem as regras sociais dos vários espaços comunitários e, nos serviços de saúde, revelavam-se de outro modo, isto é, mostravam-se resistentes, entravam em atritos freqüentes? E ainda: porque alguns, apesar dessa resistência 
desejavam retornar aos lugares indesejados, como o hospital psiquiátrico, por exemplo?

O que conseguimos apreender dessas indagações foi uma gama de novas e complexas questões que parece terem sido consolidadas ao longo de uma história de interações entre os que trabalham e os que usam os serviços.

Passo Fundo conta com três hospitais gerais, mais um psiquiátrico ${ }^{63}$, que ao todo disponibilizam um total de noventa (90) leitos na psiquiatria para a cidade e região. Esses lugares compõem o circuito principal da atenção à saúde de nossos protagonistas, prioritariamente 0 Hospital Psiquiátrico Bezerra de Menezes, o Caps, e, secundariamente, o Hospital Beneficente César Santos, o Hospital São Vicente de Paulo, o Centro de Saúde e Posto de Atendimento Médico/Farmácia e a Clínica Psiquiátrica Paulo Guedes. Vale ressaltar que a Clínica Psiquiátrica Paulo Guedes é um hospital psiquiátrico com 380 leitos, localizado no município de Caxias do Sul (distante $250 \mathrm{~km}$ de Passo Fundo) que recebe um fluxo importante de encaminhamentos. Os nossos protagonistas costumam dizer que quando se encontram em situação mais grave são encaminhados ao referido hospital, manifestando assim, uma idéia de hierarquia dos serviços em que os casos mais complexos devem ser "mandados adiante". $O$ fato de "ir adiante" denota ainda a percepção de que em cidades maiores apresentam-se possibilidades diferenciadas e melhores de tratamento.

\footnotetext{
${ }^{63}$ Hospital São Vicente de Paulo (HSVP), hospital de ensino, de grande porte, filantrópico, conveniado ao SUS. É referência para a região norte do Estado, com um total de 698 leitos, dos quais, 4 são psiquiátricos.

Hospital da Cidade (HC) que abrange também o Hospital Psiquiátrico Bezerra de Menezes (HPBM), filantrópico, conveniado ao SUS. É, também, hospital auxiliar de ensino e referência macro regional. O HC dispõe de 198 leitos, dos quais 6 são psiquiátricos, enquanto o HPBM, dispõe de 79 leitos.

Hospital Beneficente César Santos (HBCS): hospital público municipal com 96 leitos, sendo um psiquiátrico (Informações obtidas na $6^{\mathrm{a}} \mathrm{CRS} / \mathrm{PF}$ ).
} 


\subsection{A primeira internação: um "batizado" de longa peregrinação pelos serviços de saúde}

Todo o usuário terá direito a ser tratado no ambiente menos restritivo possivel, com o tratamento menos restritivo ou invasivo, apropriado às suas necessidades de saúde e à necessidade de proteger a segurança física de outros.

(Declaração da ONU, principio 9, item 1,1991)

Pela cartografia da trajetória da primeira internação ${ }^{64}$ é possível afirmar que os hospitais gerais são a "porta de entrada" mais procurada pelos familiares que lançam mão deste tipo de recurso, depois de terem recorrido a vários outros mecanismos informais e comunitários como: conselhos, rezas, bênçãos, chás calmantes e a presença mais sistemática de familiares e vizinhos, junto a pessoa que sofre. Somente quando se percebe desorganização subjetiva extrema e sofrimento psíquico, e quando esses mecanismos mostram-se inviáveis, fazendo-os perder o "controle" sobre a situação, é que se inicia a busca pelo serviço de saúde, como descrevem familiares: ocorreu diante de uma crise forte mesmo em que ele tentou se matar; no momento em que não parava mais de trabalhar dia e noite, falava uma bobajada; quando não obedecia mais ninguém, só as vozes... não poderia continuar com ele daquele jeito dentro de casa, ou ainda, quando se jogou no chão na igreja e ninguém conseguia segurar.

Esses cenários são geradores da busca de alternativas institucionais, no sentido de que as pessoas possam reaver o domínio sobre suas vidas, pois a existência-sofrimento faz com que os familiares envolvidos também se encontrem sorvidos pelas "rupturas" vividas pelo familiar, ou seja, o fato de se apresentarem comportamentos absolutamente estranhos e dolorosos, como os descritos acima, desestruturam as formas habituais da familia lidar com os seus parentes, deixando-a em desespero e impotente diante da situação. Frente à necessidade de socorro, a família parte em busca de apoios que possam compartilhar e aliviar o seu próprio sofrimento e o do parente afetado, tempo em que se trava uma batalha

\footnotetext{
${ }^{64}$ Esse arranjo foi desenhado com a presença de outros sujeitos que participaram da primeira etapa da pesquisa, não apenas com os protagonistas.
} 
individual e solitária. É o que se depreende dos relatos de familiares e protagonistas:

Fui levado para o pronto socorro do hospital da cidade, me deram umas injeçōes e de lá disseram pra mãe que o meu tratamento tinha que ser no Bezerra, ai me mandaram pra lá.

Nós corremos pro psicólogo no ambulatório, mas ele disse que não podia fazer nada, mandou que fôssemos para o hospital São Vicente. De lá disseram que o caso dela era pros outros hospitais, daí fomos pro hospital Municipal. Lá o doutor atendeu; medicaram; ela dormiu um pouco até conseguir vaga lá pro Bezerra.

Nós imploramos pra eles atenderem, corremos de um lado pro outro, mas eles diziam que tinham que atender os outros que estavam pior. A gente sofre porque pra esse problema eles nem dão bola.

Levaram-me ao pronto socorro do hospital municipal. Lembro que me fizeram injeção e depois quando eu estava um pouco mais calmo me disseram que eu ia ter que consultar num outro lugar e me levaram para o Bezerra, mas eu não sabia que ia ter que ficar lá, ai me deixaram e foram embora. Ai no início fiquei violento, agitado. Depois disso tive mais quatro vezes no Bezerra.

A constatação de uma situação não mais contornável no âmbito doméstico desencadeia um conjunto de experiências marcadas por intervenções "de passagem" e, geralmente, pouco acolhedoras para um sujeito que se encontra fragilizado psiquicamente. $O$ primeiro estágio dessa "passagem" pode ser o ambulatório de referência do bairro que exerce uma função tipicamente emblemática no cumprimento hierárquico do sistema de saúde, como expressa um dos seus "usuários": é o lugar de pegar o encaminhamento. Essas coisas eles não resolvem, ou: tem que passar por ai primeiro, senão eles mandam de volta.

Em seguida vem a "passagem" pelos postos de emergência dos hospitais da cidade. Normalmente, o mais procurado é a emergência do hospital São Vicente de Paulo que, após detectar o caráter "psiquiátrico" do caso, e em não havendo outras interocorrências que caracterizem o risco iminente de perder a vida, faz a triagem para os outros dois hospitais (HBCS ou $\mathrm{HC}$ ), sob a alegação de que um tratamento clínico como merece o caso, não necessita de todo o aparato tecnológico disponivel no serviço de emergência que deve ser reservado aos atendimentos mais graves. No 
HBCS ou no HC, o "usuário" é medicado e, normalmente, referenciado para internação no hospital psiquiátrico que é a base da atenção psiquiátrica para esses casos no sistema de saúde do município. Em não havendo vaga, ou o médico assistente não indicando internação, o "usuário" retorna para casa com orientação medicamentosa.

A partir desses exemplos, procuro alguns significados nas relações produzidas nesse percurso em que os sujeitos são "batizados" no mundo psiquiátrico, tendo a internação psiquiátrica como a principal, senão a única alternativa para conter uma situação de crise. É indiscutível que nessas situações há algo a ser contido e organizado. Porém, esse trabalho de contenção e organização do mundo subjetivo pode ser construído e favorecido através de métodos bem mais eficazes junto a outros espaços institucionais, a exemplo das experiências descritas por Lobosque (2003) e Golberg (1996) que acolhem pessoas com crise psíquica grave em Centros de Saúde ambulatoriais, tendo como princípios fundamentais a participação e o consentimento desse cidadão ao tratamento: "trata-se de um apelo à capacidade de produção, presente em todos e particular a cada um - por onde passa, necessariamente a saída da crise" (LOBOSQUE, 2003, p.88). Vale dizer que esses princípios são estranhos às trajetórias de nossos sujeitos.

Concordo com Lobosque (2003) e Marcolan (2003). De fato, se os profissionais dos serviços de saúde estivessem em consonância com as questões que emergem do sujeito nas circunstâncias de uma crise - ocasião em que se manifestam determinadas estruturas que estavam silenciadas -, seria possivel constituir um entendimento consistente para essa questão específica compreendendo as particularidades de cada um e apontando saídas menos restritivas.

Mesmo assim é possivel afirmar que as situações descritas pelos depoentes são as que mais se aproximam do critério "técnico" (do ponto de vista médico) para internação, fato pouco freqüente nas internações subseqüentes que acompanhei durante a pesquisa de campo. Pelas 
histórias contadas é possível afirmar que na primeira internação a procura dos serviços deu-se em um momento marcado pela gravidade em que havia necessidade de cuidados intensivos, pois o adiamento de uma intervenção dessa natureza acarretaria risco de morte ao "usuário".

De todo o modo, há de se questionar o que buscam esses sujeitos nos serviços de emergência: contenção, medicamento, sedação, credibilidade? Em que medida o "acolhimento" feito no momento da crise responde às suas necessidades?

Afinal, o momento da crise é propício a que se inicie um processo de acolhimento e compreensão da produção subjetiva - esfacelada, emergente, desencontrada e sofrida -, restabelecendo nexos que possibilitem o encontro de uma saída possivel. É preciso, neste momento, estabelecer conexões com o mundo concreto que estejam voltadas para o lado "saudável que ainda resta"; ou seja, é tempo de explorar um canal, para que o mundo subjetivo não continue insustentável, colocando o sujeito cada vez mais "fora", restando-Ihe como única via de escape, a própria loucura. Com isso, não estamos negando a necessidade de intervenção medicamentosa até para sedar e conter quimicamente por algumas horas, aliviando a tensão do sujeito e a de seus familiares.

No entanto, os espaços das emergências são normalmente aparelhados para atendimentos rápidos, precisos e transitórios. Aí não se tem a preocupação de estabelecer vínculos, sobretudo com os "casos psiquiátricos", o que denota, aliás, uma dificuldade na atenção (não se recebe, manda-se para outra emergência). Se, por um lado, é extremamente necessário que esses espaços sejam de intervenção rápida e precisa, voltada para situações graves especificamente; por outro, é questionável que as emergências dos hospitais gerais (atualmente os únicos lugares para atendimento de emergência psiquiátrica na cidade) atendam com um único (ou principal) propósito: o de "suprimir a crise" pela via medicamentosa, ou melhor, o de apenas sedar, sem nenhuma preocupação com o "acolhimento" e cuja decisão principal seja, geralmente, encaminhar o sujeito para um 
tratamento fechado (hospital psiquiátrico), fortalecendo assim e cada vez mais, o circuito crise/emergência/internação psiquiátrica.

Todavia, o problema não está somente nesses serviços que parecem não reunir condições adequadas - física e de pessoal - para o atendimento de pessoas com crise psicótica. Na região, sofremos também com a insuficiência de espaços substitutivos, equipados de recursos para a composição de um itinerário terapêutico que amplie as alternativas de cuidado ao sujeito no momento de um sofrimento psíquico.

Retomemos o ponto de partida dos familiares. Esses, por questões diversas, - que vão da negação de que um membro da família esteja vivendo um processo dessa natureza, até o desconhecimento, ou ainda, a dificuldade de acesso a uma rede de saúde - buscam o serviço em situação de profundo sofrimento e necessidade, quando se toma inviável a manutenção de contato sócio-familiar ininterrupto. Mesmo assim, as trajetórias de familiares e "usuários" pelo sistema demonstram que eles acionam a rede geral de saúde que, por sua vez, dá pouca vazão a esse sofrimento humano, endereçando-Ihes logo o seu lugar dentro do circuito.

Chamo atenção para "detalhes" que envolvem essa trajetória, como as "correrias" com recusas de atendimento, as longas esperas, a desconsideração da gravidade quando se trata de "paciente psiquiátrico", as intervenções medicamentosas e de isolamento, para ilustrar o quanto esse percurso está impregnado de idéias e práticas de um poder instituído que atravessa as relações, numa malha quase invisivel operada na micropolitica da atenção à saúde. Trata-se de algo semelhante ao que Basaglia chamou de poder institucionalizante ${ }^{65}$, guardada a diferença de que o autor trabalhou com populações institucionalizadas em hospitais psiquiátricos de longa data. Em nosso caso, trata-se do primeiro acesso ao circuito da saúde de uma

\footnotetext{
65 Basaglia, citado por Amarante, refere que o "Poder institucionalizante" é o conjunto de forças, mecanismos e aparatos institucionais que ocorrem quando o doente, fechado no espaço augusto da sua individualidade perdida, oprimido pelos limites impostos pela doença, é forçado, pelo poder institucionalizante da reclusão, a objetivar-se nas regras próprias que o determinam, em um processo de redução e de restrição de si que, originariamente sobreposto à doença, não é sempre reversível (AMARANTE, 2003a).
} 
rede predominantemente "não psiquiátrica" (hospitais gerais e ambulatórios) que, aparentemente, mantém padrões de atendimento $e$ atitudes institucionalizantes semelhantes àquelas estudadas por Basaglia, sutilmente disseminadas nos atos cotidianos de se relacionar e agir com as pessoas que buscam essa rede. Nesse sentido, não é necessário passar meses ou anos internado em instituição psiquiátrica para viver a reclusão. Basta que 0 sujeito procure um serviço de saúde na cidade. Esse trajeto é balizado por resistências, forçando a internação psiquiátrica que, ao invés de última, passa a ser a única alternativa para a situação da crise. O "batismo" à institucionalização ${ }^{66}$ tem, portanto, início na solicitação do ingresso à rede de saúde.

Apesar da legislação psiquiátrica vigente referir-se à substituição do hospital psiquiátrico por uma rede de serviços abertos, comunitários, etc, e com o que concordamos integralmente, vale ressaltar que esses espaços a rede geral de saúde -, embora apresentem diferenças positivas em relação ao espaço fechado, também estão impregnados dos saberes e práticas manicomiais. Seus efeitos nos alertam para a dimensão da 'empreitada' de construir um outro referencial nesse circuito, capaz de acolher e tratar com dignidade o sujeito em sofrimento psíquico.

Dessa forma, constatamos que o lugar ${ }^{67}$ dado para a situação de crise vivida pelos sujeitos é construido a cada etapa dessa trajetória, na qual profissional e instituição negam a possibilidade de escuta, não possibilitando nem favorecendo um espaço de acolhimento e tratamento adequados. Durante a pesquisa, não identificamos nenhuma situação em que a pessoa

\footnotetext{
${ }^{66}$ Para Basaglia, a "institucionalização" é "o complexo de 'danos' derivados de uma longa permanência coagida no hospital psiquiátrico, quando o instituto se baseia sobre principios de autoritarismo e coerção. Tais princípios, donde surgem as regras sob as quais o doente deve submeter-se incondicionalmente, expressam e determinam nele uma progressiva perda de interesse que, através de um processo de regressão e de restrição do Eu, o induz a um vazio emocional" (Citado por AMARANTE, 2003a).

${ }^{67}$ Marc Augè, ao se referir aos "não-lugares", esclarece o conceito de "lugar" de acordo com - que aqui nos referimos. Um espaço que "pode se definir como identitário, relacional e histórico [...] é o lugar no sentido inscrito e simbolizado [...] incluimos na noção de lugar antropológico a possibilidade dos percursos que nele se efetuam, dos discursos que nele se pronunciam e da linguagem que o caracteriza" (AUGE, 2001, p.73-76).
} 
tenha sido conduzida (por seus familiares) diretamente ao hospital psiquiátrico da primeira vez que buscou os recursos de saúde. Todas as situações acompanhadas seguem o mesmo fluxograma descrito adiante, fato que parece ir além do difícil acesso ao hospital psiquiátrico e ali não dispor de um serviço de emergência ou pronto atendimento, como expressa a mãe de um protagonista: Deus me livre, mas eu não queria levar meu filho pra lá por nada na vida, tinha muito medo de largar ele no meio dos loucos, o que podiam fazer com ele [...] depois eu vi que não são tão diferentes de nós. Só é ruim porque fica isolado! De início, esta mãe parece verbalizar o que está no imaginário social da cidade. Eu não queria levar o meu filho pra lá por nada na vida..., expressa o que ela, a exemplo de muitos outros, pensa sobre o hospital psiquiátrico - o lugar onde se guardam todas as "maluquices da cidade" - um jargão tão usado pelos moradores: "devia estar no Bezerra", quando querem se referir a alguém que faz alguma coisa fora do esperado. Daí o hospital psiquiátrico representar um espaço não desejado para se deixar um familiar, mas, que aos poucos, vai perdendo esse poder simbólico, à medida que as internações vão se tornando sucessivas. A experiência das freqüentes internações socializa a pessoa em sofrimento psiquico e seus familiares no circuito. Por isso apresentam-se "acostumados" à situação e "conformados" com o fato de não serem atendidos em suas necessidades, desejos e anseios; ao contrário, aprenderam que esses lugares prestam-se a "aprisioná-los". Estabelece-se um "conjunto de forças, mecanismos e aparatos" que operam nesse processo a favor da estigmatização, constituindo uma experiência difícil de ser revertida na seqüência de suas trajetórias.

Cabe ainda dizer que essa trajetória é reveladora da dissonância da política local de saúde mental com relação à reforma psiquiátrica e aos "princípios de proteção de pessoas acometidas por transtornos mentais" da ONU. Primeiro, a gestão local de saúde não estabelece nem viabiliza fluxos claros, submetendo as pessoas a percorrê-los por conta própria; além disso, pessoas com esse grau de sofrimento entram e saem dos hospitais sem serem "descobertas" pelos serviços territoriais ambulatoriais ou, se são 
descobertas, não entram em uma agenda de acompanhamento. Esses fatos confirmam a centralidade do hospital, a intervenção apenas nos momentos de crise e a institucionalização.

O segundo indício desta dissonância diz respeito à responsabilização dessas instituições pelo cuidado aos "usuários". No momento em que "o dilaceramento psíquico atinge plenamente o sujeito, um certo modo de acompanhamento, de presença, de atos e palavras faz-se necessário como forma de ajuda". Essa ajuda não pode se colocar como "forma de interferir, aliciar, tutelar, dominar etc", mas sim, como forma de admitir essa implosão que a crise provoca, suportá-la e torná-la suportável, dando ao sofredor um limite necessário flexivel para construir com ele, que é o maior interessado, um projeto terapêutico (LOBOSQUE, 2003, p.20). De outra forma, há de se desenvolver serviços capazes de construir e preservar o vínculo com os "usuários" do território, nos diversos momentos em que o sofrimento se apresenta, de modo a fugir dessa relação despersonalizada e sem responsabilidade. Essas são questões a serem aprofundadas por todos, para que a marca deixada num momento tão sensivel da vida seja a do acolhimento e do suporte para a reestruturação do mundo subjetivo e da identidade do sofredor psíquico.

Fluxograma da trajetória da primeira internação percorrida pelo circuito da atenção em saúde:

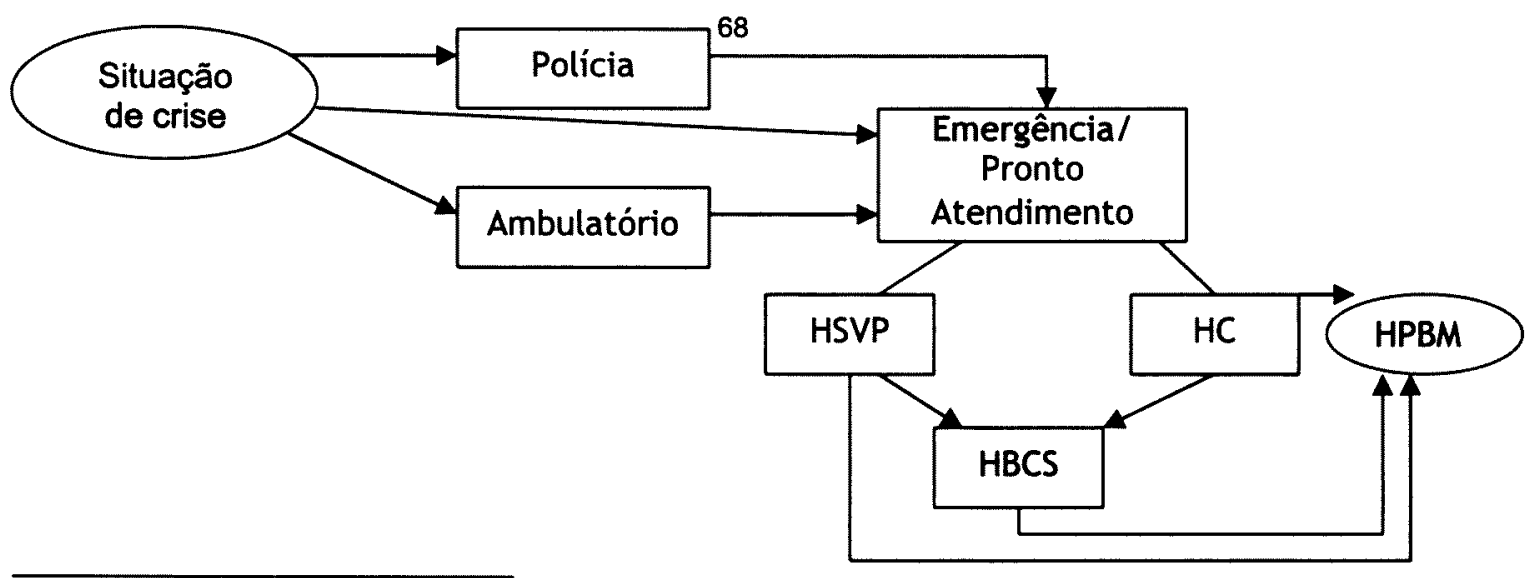

\footnotetext{
${ }^{68} \mathrm{~A}$ policia aparece como estratégia a ser acionada nas dificuldades de convencimento para internação, ou, quando a pessoa em sofrimento apresenta algum risco de auto ou hetero agressão. Desempenha um papel de apoio intermediário entre o domicílio e o hospital, procurando dar a proteção a todos os envolvidos.
} 


\subsection{A "caixa de Pandora"69 dos serviços de atenção à saúde mental}

Em contraste com a trajetória da primeira internação, que ocorre no momento em que os recursos disponíveis não são mais suficientes, e, após o batizado desta primeira experiência, as reinternações passam a ganhar outros atributos, como já sinalizamos no quarto capítulo. $O$ estoque de "conhecimento" à mão dos familiares e do sujeito é ressignificado a partir de cada nova experiência.

Existem códigos muito sutis inscritos no âmbito familiar, profissional e das instituições de saúde que permeiam o convívio com a pessoa em sofrimento psíquico. Para cartografar as internações psiquiátricas nesse trabalho, tivemos de romper com a noção de um sistema de saúde hierarquizado, dando lugar a um considerável número de outros pactos apreendidos nos percursos. Percebi que havia uma convivência de dois códigos predominantes: um "moderno e humanizado" - no qual os direitos do cidadão estavam acima de qualquer suspeita (mais visivel nos jornais, discursos, projetos terapêuticos das instituições) e outro - "conservador e autoritário" - através do qual se estabelecia a dinâmica das relações interpessoais, referentes à busca de internação no cotidiano dos sujeitos. Contudo, a coexistência e imbricação entre esses códigos são pautadas pela supremacia do "não louco" sobre o "louco" e de relações marcadas pela normalização do social.

\subsubsection{Entre a familia e a instituição de saúde: o 'endereçamento' dado aos sujeitos que vivenciam o sofrimento psíquico}

Durante um ano de trabalho de campo acompanhei a trajetória de um dos protagonistas, cartografando os três momentos em que a internação o desviou da sua rota instituinte. Sem registro das internações anteriores, a

\footnotetext{
${ }^{69}$ Conta a mitologia que na antiga Grécia, como presente de casamento, Pandora recebeu de Zeus uma caixa lacrada com a instrução de que não deveria abrí-la. Mas a curiosidade era enorme e Pandora desobedeceu. Destampando a caixa, dela escaparam todos os males que hoje assolam a humanidade, inclusive a doença e a morte. Pandora ainda tentou fechar a caixa, mas era tarde demais: ela estava vazia, com a exceção da "esperança" que permaneceu junto à borda da caixa.
} 
mãe afirma que o internava desde criança, embora internação psiquiátrica mesmo, venha ocorrendo, segundo ela, desde que o Hospital Bezerra de Menezes foi inaugurado, em março de 1990. Os depoimentos dos familiares acerca dessas três internações podem ser elucidativos da dinâmica própria e dos pactos presentes nesse episódio, como também, revelam as marcas que não se apagam da lembrança de quem vive esse processo. Um diálogo entre ele, seu irmão e eu esclarece, de algum modo, as circunstâncias em que a internação acontece, bem como o que o sujeito pensa sobre ela.

O irmão se aproxima:

- tu gostas tanto de sair, mas porque não queres ir ao hospital? Beija-Flor levanta o tom de voz e se dirige a mim:

- Dona Bernadete, se te levarem pra um lugar, te enrolarem e não te deixarem mais sair, o que tu acha?

O irmão insiste: mas tu não queres ir nem nas revisões?

Revisões, revisões - retruca Beija-Flor: Já me levaram pra revisão e me deixaram lá não sei quanto tempo. Nunca vi revisão ter 30 , 60 dias.

Percebi que Beija-Flor refere-se à hospitalização com revolta. A conversa continuou e todos nós falávamos, embora ele falasse mais: o hospital é muito sofrido, porque lá não tem o cara querer alguma coisa. E, já bem mais alterado, pede-me, por favor: será que a gente podia deixar de falar de hospital, se não eu não falo mais.

Retomando a primeira das três internações de Beija-Flor, já citada no inicio desse trabalho, podemos lembrar de que a mãe falou das constantes quedas em decorrência dos ataques, de como ele passava o dia na rua e por isso corria mais riscos de se ferir. Falava também da queda que sofrera e do socorro prestado por policiais que o levaram ao prontoatendimento e, finalmente, da decisão da irmã, responsável por ele, de interná-lo, conduzindo-o até o hospital sob a alegação de que devia se consultar. Ele fala que não somos nós que ficamos naquela prisão, mas com ele é só na chave, senão ele foge. Dos outros hospitais ele sempre fugiu, então, eu dou graças a Deus que tem esse Hospital, reforça a mãe. 
A irmã que é sua curadora ${ }^{70}$ referiu-se à situação do irmão como muito complicada, ele é o nosso 'karma', passa mais no hospital do que em casa. Não sei até quando, justificando porque lançam mão desse recurso com regularidade: quando ele está em casa sai para rua, ai os vizinhos reclamam que ele encrenca, além de correr riscos de receber uma surra ou ser atropelado. Quando tentamos repreender em casa dizem (os vizinhos) que mantemos em cárcere privado. A gente nem sabe o que fazer, então ele reclama que lá é ruim, que é prisão, mas lá, pelo menos, é permitido. É permitido deixá-lo no hospital, porque lá, apesar das condições desfavoráveis a ele, a imagem da família fica preservada, pois está longe dos vizinhos que a acusam de maus tatos.

Com o subterfúgio do perigo e das reclamações dos vizinhos (situações que não presenciei durante a pesquisa), três meses depois do retorno da internação anterior, Beija-Flor foi reinternado. Soube de sua indignação e revolta através de uma informante. Para compreender melhor esse momento vivido por ele, resolvi procurá-lo no hospital. A situação abaixo é ilustrativa de interações da dinâmica institucional.

Estive lá no horário de visitas, pois queria evitar o pedido de autorização. Mas, logo na entrada, acabei sendo reconhecida por um profissional que me recebeu e foi logo justificando que toda a equipe estava de saída para um "treinamento sobre humanização" em outro hospital. Feita a solicitação de visita e identificado o paciente, fui levada à unidade de internação, onde Beija-Flor já havia sido convidado a entrar em um dos consultórios para o qual fui, também, conduzida. Percebi que estava alterado, o que, de certa forma, me tirou um pouco a iniciativa, pois imaginava encontrá-lo nos corredores, ou no pátio ${ }^{71}$ do hospital. Também vivi, naquele momento, a sensação de estar trancada. O profissional, na tentativa de nos proporcionar um espaço "mais adequado", fechou a porta e nos deixou. Beija-Flor foi hostil. Por alguns instantes arrependi-me de ter ido

\footnotetext{
${ }^{70}$ Como curadora, recai também sobre ela a decisão de quando e como interná-lo, restando aos outros membros da familia um papel secundário na questão da internação.

71 Espaço do próprio hospital, delimitado por uma cerca, onde os internos passam pouco mais de uma hora em cada turno quando não está chovendo ou molhado.
} 
ao seu encontro. Ele transferia para mim a responsabilidade por sua internação. Convidou-me a sentar em uma cadeira atrás da escrivaninha, que era o lugar do psiquiatra. Reagi, propondo que conversássemos no corredor (nesse dia não haveria "pátio" para ninguém porque a equipe técnica estava em treinamento fora), mas ele não me ouviu. Disse-lhe, então, que havia estado no bairro e sentido sua falta, ao que ele retrucou, culpando-me pela internação. Segundo Beija-Flor, se eu não tivesse conversado com seu irmão e com sua mãe (mais ou menos, três meses antes), ele não estaria lá.

Ouvi seu desabafo em silêncio. Ele logo relaxou, contou-me sobre o compromisso que assumira com uma namorada, que justificava como mais um motivo para não permanecer ali, além de não poder realizar o seu trabalho como office-boy. Imaginando que eu tivesse poderes para suspender sua internação, chegou a sugerir que interferisse em favor de sua alta hospitalar. Irritou-se novamente quando lhe disse que não podia fazer isso, deixando-me desconfortável e ansiosa por estar em uma posição "expectante" nessa relação.

Beija-Flor estava indignado com as irmãs que o levaram ao hospital: olha aqui, só porque eu não tomei o remédio na hora que ela queria, eu tô aqui, tu viu? Só porque eu quis fazer do meu jeito que na verdade foi do jeito que o médico me mandou. Queria encontrar motivos que justificassem sua permanência no hospital, o que só fazia aumentar suas confusões, uma vez que esses motivos estavam conectados a outros fatores do contexto familiar, que foram ganhando sentido para mim a partir das ligações dessa trama.

A situação do hospital reportou-me, outra vez, a casa de Beija-Flor onde conversei com sua mãe: dessa vez, disse ela, a internação não foi por doença, nem por ataque, ele estava bem, mas eu que não estava nada boa. Ela havia sido internada com pressão alta, ansiedade e alguma coisa na cabeça que parecia que fosse levar a memória embora. Por isso, ao procurar atendimento para a mãe, a filha tratou de solicitar a internação de Beija-Flor, no que foi prontamente atendida pelo médico psiquiatra. Isto, o 
próprio Beija-Flor desconhecia, mas a mãe justifica: ele fica muito na rua, e eu não estando em casa... Lá ele fica bem cuidado, tem os enfermeiros, tudo. Seu cansaço em relação à doença do filho se expressa pela sobrecarga que sente no convívio diário com ele: quando ele chegava, eu já não conseguia mais ouvir a fala dele de zonzeira na minha cabeça, porque ele chega da rua e quer me contar tudo: das namoradas, com quem conversou, o que fez... Então, agora ele fica uns trinta dias por lá. Pensei ainda: e se as condições socioeconômicas fossem outras, essa situação teria outro desfecho?

Sem poder responder a essa questão, o que registro é que a condução do processo de internação segue um ritual pactuado entre médico, família e hospital: a internação foi tranqüila, minha filha (a curadora) disse a ele que o médico pediu para consultá-lo. A mãe afirma que elas usam essa estratégia porque ele não aceita internar-se, ele tem medo que deixem no hospital, então a gente não anuncia. Na atual internação, a irmã, de posse do laudo, chegou no hospital e, os funcionários foram entretendo ele, chamando: oh Beija-Flor,... E ela virou as costas e saiu de mansinho. Não levou nem a carteirinha do convênio, roupa, nada pra ele não desconfiar. Aí no dia seguinte a filha foi lá e ele, não estava mais brabo, porque mandou 'melhoras' pra mim.

O alívio sentido pela familia com a ausência de Beija-Flor era visível na serenidade da mãe e na maneira afetiva com que ela e a filha me acolheram (convidaram-me para entrar, tomar chá, mostraram-me fotos da família). Foi a primeira vez que eu me senti bem recebida pela familia. A presença de determinados "códigos", tanto nas falas de familiares quanto nas dos profissionais - não adianta fazer nada, de tempos em tempos ele fica assim e tem que internar; ele bronqueia na rua; não dá pra falar com ele, ele é exagerado, não te preocupe; ele manipula demais ou ainda, a internação é para o seu bem! - vão anunciando a forma natural como a internação psiquiátrica é tratada nessas inter-relações. 
Na dinâmica das conexões é que se pode perceber a complexidade dos desfechos cotidianos, da relação com a situação de adoecimento, da fragilidade da voz do sujeito. Do Beija-Flor registro a dificuldade de lidar com um sistema altamente entrópico que reduz significativamente sua capacidade de trocas, de relações, de desejos contrastantes com a tranqüilidade da familia - mãe e irmãs - diante da situação. Esse arranjo é gerado na dinâmica marcada pela cumplicidade existente entre a família, 0 médico e o hospital. A familia se beneficia com o alivio da ausência por alguns dias, mantendo a tranqüilidade de saber que Beija-Flor não está na rua (embora a rua não seja problema para ele) e será, na concepção deles, "bem cuidado"; o médico atende a solicitação da familia ou acha uma "causa" para justificar a situação da mãe, "ajudando-a"; o hospital acolhe a solicitação, oferecendo um suporte temporário, mesmo sabendo que daqui a pouco, a família vai fazer o mesmo percurso e que a situação de vida do internado não vai melhorar com a internação. Parece ter se estabelecido um circuito solidário entre família, médico e hospital, excetuando-se o protagonista que não foi ouvido nesse processo e que, tampouco, encontrava-se em situação que justificasse a internação por critérios técnicos, fato que torna maior ainda a resistência a esse tipo de procedimento.

Há que ressaltar, como fizemos anteriormente, a palavra do sujeito como matéria-prima do tratamento, por mais desorganizada e delirante que esteja, constituindo-se esta, no primeiro passo para romper o lugar inerte ou a falta de lugar do sujeito nessa interação. Embora o acompanhante/familia reúna elementos necessários para avaliação de determinadas situações, como a de uma crise, o consentimento para tratá-lo "só se faz quando colocamos em primeiro plano as palavras que nos traz, considerando o lugar desde onde ele se enuncia". Essa busca não só não exclui o envolvimento de parceiros (quer da família ou de terceiros), como, por vezes, torna-se fundamental e recomendável, contanto que não se torne uma cumplicidade desses "parceiros" em detrimento da anuência e do desejo do "usuário" (LOBOSQUE, 2001, p.37). 
Para reforçar a hipótese de que determinados serviços, através das relações que estabelecem com familiares e sujeitos com problemas psiquicos, tornam-se refratários às possibilidades de expansão da vida, registrei, de maneira semelhante às demais, a terceira internação do periodo da pesquisa, e o quarto mês de "reclusão" de Beija-Flor na mesma instituição. A irmã mais velha diz-se receosa em levá-lo para o Bezerra (Hospital psiquiátrico), mas a curadora é quem decide, porque qualquer coisa que aconteça com ele, ela terá de responder. Afirmou ainda, que o irmão não vinha se alimentando direito e continuava com as convulsões. Uma noite caiu aqui em casa e a (curadora) ligou para o hospital na hora, porque ai ele fica meio confuso, sabe [...]. O funcionário disse que podiam levá-lo, ai baixou. Então, o "socorro" que a familia busca vem de um modelo regulador que cumpre um papel, mesmo que não mais satisfatório a todos os seus membros, ainda necessário ao restabelecimento da ordem familiar.

Cabe refletir aqui a respeito da "interdição" que, no caso desse protagonista, retira-lhe todos os direitos, transferindo-os para 0 representante legal. Dentre esses direitos está o do consentimento para internação. Se, por um lado, a curadora está respaldada legalmente quanto a tomar as decisões pelo responsabilizado; por outro, não está buscando/encontrando os meios adequados para o seu tratamento. Há, nessa relação, pelo menos uma grande contradição que deveria passar pela revisão do Ministério Público, a saber, a da interdição total. No caso desse interdito, ele vem apresentando uma série de resistências plausiveis em relação à internação, e demonstra, no cotidiano, que tem condições, pelo menos parciais, de discernimento para exercer atos da vida civil.

Mas, para além da interdição, cabe uma reflexão sobre o lugar, a função de Beija-Flor na familia, para buscarmos a compreensão dos pactos e arranjos estabelecidos. Conforme afirmamos anteriormente, se os papéis familiares não forem "trabalhados" no seu conjunto, a tendência é manter os fatores não suportados dessa relação familiar sobre um dos seus membros doentes, ou seja, os medos, as tensões e conflitos do grupo continuam sendo, em grande intensidade, "depositados" no familiar que adoeceu. Essa 
dinâmica leva ao empobrecimento dos elementos que se entrecruzam e se entrelaçam nessa relação, dificultando o rompimento das estereotipias que circundam todo o circuito familiar. Nesse sentido estamos de acordo com Rivière ao propor que a família seja incluída na compreensão do adoecimento psíquico, pois, o sujeito que desenvolve a doença é o emergente de um grupo familiar cuja dinâmica apresenta uma série de dificuldades não elaboradas no decorrer da história familiar e, às vezes até, na história de gerações. Mesmo de forma inconsciente, alguém vai assumindo a função de "depositário e porta-voz" dessas dificuldades, como forma de preservação do grupo. Esse alguém é o sujeito que adoece (RIVIĖRE, 1988).

Melman (2001) afirma acertadamente que não podemos negar a sobrecarga que recai sobre os familiares ao ter de acompanhar e cuidar dos seus membros adoecidos. Essa sobrecarga poderá advir do medo, da responsabilidade com o cuidado, da culpa, da frustração, enfim, da dificuldade de lidar com a complexidade que envolve a situação. Tal processo convoca a família aos mais diferentes sentimentos, entre eles, o da penalização, o da insegurança, da impaciência e da necessidade de transferir para outrem a responsabilidade por alguém que a coloca no limite de sua (in)capacidade enquanto tal e para o cuidado. A falta dessa troca de lugar (es), de não trabalhar mais integralmente essa unidade complexa acaba reforçando uma única via de alivio desses familiares que também não conseguem escapar da lógica psiquiátrica, encontrando na internação um espaço para "depositar" tamanha sobrecarga. Sem outro tipo de apoio terapêutico acabam sofrendo e endurecendo, criando assim suas próprias estratégias de fuga temporária, (des)humanizando e sendo (des)desumanizados.

Nessa direção é compreensível que a partir de determinado momento das trajetórias das pessoas que vivem esse sofrimento haja um certo "endereçamento" para a internação por parte dos familiares. A internação psiquiátrica, por sua vez, a despeito de se constituir, do ponto de vista médico, em uma operação terapêutica, não ocorre apenas graças a 
critérios técnicos. Analogamente ao que observou Souza (1999) em nosso estudo também observamos que a decisão de internar, ainda que se necessite do médico para fomecer o laudo, é uma iniciativa da família, a exemplo do que ocorreu com vários casos e situações vividas por nossos protagonistas. É, predominantemente, a familia que regula até que ponto os comportamentos serão aceitos e toleráveis no meio social e, ao chegar no profissional, é ela quem usa diversos mecanismos para convencê-lo do caminho a ser seguido na busca de restabelecimento da normalidade que se perdeu. Na maioria das vezes, é um "encontro" sem resistência. É nesse lugar de restauradores da norma que os psiquiatras, via de regra, se colocam e respondem às famílias. Com esse propósito de entrada na instituição, a saída não poderia ser diferente: esperar o tempo padrão, sem que se confira o peso terapêutico desse recurso na história do sujeito, distante da "menor duração temporal possivel" estabelecida em lei.

No entanto, a aceitação, por parte dos profissionais e das instituições, desse endereçamento sem nenhum questionamento da relação, e sem que se ouça o sujeito diretamente envolvido, denuncia a gravidade desses arranjos que afetam sobremaneira os direitos humanos mais fundamentais. Esta situação de desrespeito torna-se ainda mais grave por envolver sujeitos em condições desfavoráveis, em posição de desvantagem social. Dai é que se depreende a necessidade de políticas de proteção que diminuam as dificuldades dos sofredores psíquicos, ajudando-os a "escapar" de situações de vida que os oprimem, que os impedem de estabelecer um contato mais direto com tudo aquilo que é fundamental para a existência (MELMAN, 2001). Contrariamente, o que parece prevalecer nesse arranjo é a incapacidade do profissional de sair desse lugar de mero receptáculo de prescrições para se tornar um construtor de outros projetos, o que requer trazer à cena essa trama de interconexões.

O episódio vivido por João-de-Barro é mais um exemplo do que acabamos de expor. Mesmo em situações em que ocorre a resistência à internação e o protagonista tem o apoio de seus familiares, a indicação e a estratégia dos profissionais mantém-se inalterada. Após dar entrada na 
emergência hospitalar por uma interocorrência clínica associada ao seu problema psíquico, ele foi encaminhado para o hospital psiquiátrico. Como era sabido que João-de-Barro estava determinado a não mais se internar no "Bezerra", não the comunicaram de que isso poderia acontecer a qualquer momento, e a enfermeira encarregada da transferência para o referido hospital tentou fazer um acordo com a mãe. Pediu que ela não dissesse nada a João-de-Barro, que ele seria sedado e conduzido ao hospital psiquiátrico. Seu pai, avesso à internação e aos remédios, contou ao filho o que aconteceria, aumentando ainda mais a sua resistência, conforme relato do próprio João-de-Barro: Eu avisei que se me levassem à força eu bateria em quem tivesse
na frente. Pra eu sair do hospital, meu pai teve que ir lá assinar,
responsabilizando-se, porque eles não queriam me liberar pra ir
pra casa. Disseram que o meu caso era psiquiátrico. Psiquiátrico
eu sei que é, mas o que o Bezerra vai fazer comigo? Eu mostrei
que tinha consulta na segunda-feira com o doutor [...], e minha
mãe disse que ela me daria o remédio todo o dia, além de ir no
Caps. Aí me liberaram.

Esse exemplo ilustra, mais uma vez, a falta de articulação dos serviços em rede e a manutenção de um único caminho reconhecido para situações psíquicas diversas. O próprio serviço diário freqüentado por Joãode-Barro não conseguiu aliviar o seu sofrimento, e nem o encaminhou a lugar algum, num momento em que a situação se agravara subitamente. $O$ profissional/instituição que o atendeu, por sua vez, também não reconheceu o serviço de origem, referenciado-o para o hospital psiquiátrico, apesar da solicitação de João-de-Barro de dar continuidade ao tratamento fora do hospital.

Nessa fusão de inter-relações aí estabelecidas identificamos que o circuito: crise/doença mental, internação psiquiátrica, prescrição medicamentosa, alta hospitalar e re internações permanece inalterado na realidade local. Diante disso, faz sentido perguntar como oferecer atenção através de outros recursos e territórios que possibilitem o desenvolvimento desse sujeito sem retirá-lo das situações de convivio social, já que é nessas circunstâncias que ele aprende regras, ganha autonomia, constrói arranjos 
possiveis de trocas? E por que não pensar na familia como foco principal dos serviços, oferecendo-lhe suporte para viver com seu familiar em liberdade? Como auxiliar no estabelecimento de um diálogo entre os diferentes envolvidos na relação com esses sujeitos, de tal modo a dispensar uma resposta a priori?

\subsubsection{A 'acolhida' do sujeito ou o recrudescimento da falta de liberdade?}

A impossibilidade de falar, de ser ouvido e reconhecido em sua singularidade marca a chegada e os primeiros momentos das internações que são pautadas por intervenções extremamente invasivas. Sem negociação com os sujeitos, esse tipo de chegada provoca reações como agitação e violência, que acabam por justificar as contenções, as condutas reiterativas dos rótulos e estereótipos dos "usuários". Destacamos aqui, alguns fragmentos relativos à chegada dessas pessoas em instituições psiquiátricas:

Pra mim foi um choque chegar no Bezerra. Meio confuso, sem saber porque eu fui parar lá no meio de toda aquela gente. Me lembro que me mandaram tirar a roupa, me jogaram uma toalha $e$ me deram umas roupas pra vestir, mas não roupa de hospital, umas roupas velhas, amassadas (depoimento de Sabiá).

Naquele dia ele foi medicado no hospital geral e encaminhado pra internação, mas mandaram pra Caxias porque ele tava feio. No dia seguinte ele próprio foi na Secretaria de Saúde amumar a vaga, o transporte, ajeitou tudo. Ai eu fui junto, mas quando chegou lá quem disse que ele queria ficar, não queria mais! Lá ele não podia ficar com nada das suas coisas. Ele tinha pedido pra levar um monte de coisa boa, foi de sacola cheia das coisinhas que gostava. Quando tiraram as sacolas, ele se agarrava nelas como uma criança. Lá foi triste, pois eles tiveram que manear como se maneia um animal, jogaram no chão $e$ agarraram à força. Aquilo me cortou, mas o que a gente ia fazer, a gente tinha ido até lá pra internar, com a prefeitura, tudo, não podia voltar com ele. Lá foi muito ruim porque era longe e a visita era só de quinze minutos. A gente gastou mais de cem reais eu e a minha filha e só pudemos ficar com ele quinze minutos (depoimento de familiar de João-de-Barro).

Quando cheguei me agitei porque não sabia que ia ter que ficar lá, ai me botaram na primeira semana num quartinho fechado. Ai eu enlouqueci mesmo. Me colocaram no colete (descreve o procedimento das faixas de contenção amarradas pelo corpo) $e$ me deram injeção, direto, durante uma semana. É o que eles 
chamam de UTI. Depois de uma semana, fui pro grupo cinco. Lá era melhor, a gente até ajudava (depoimento de Sabiá).

Por telefone, João-de-Barro contou-me sobre sua última internação, dizendo que também passara pela CTI: eu quando cheguei, tive que ficar uma semana na $\mathrm{CTI}$, não entendi porque se não estava agressivo e conseguia me cuidar. Um dia que o doutor veio aqui eu disse: 'doutor, qual é - motivo pra me manter aqui'? Ai ele mandou me tirar e, em tom confidencial, complementou: aqui a gente tem que agüentar certas coisas pra não voltar pra CTI. Depois de muito insistir, e aos nove dias da internação, consegui falar com João-de-Barro, porque havia uma só linha para contatos dos internos (eram 380) com seus familiares e amigos. $O$ caráter asilar também se mostra na relação com os técnicos: desde que eu cheguei falei duas vezes com o doutor - quando eu cheguei e quando eu pedi pra me tirar do isolamento - e uma vez com a assistente social com quem tratei sobre as compras pessoais (material de higiene, cigarro, lanches).

Outras ações e interações registradas em documentos e relatadas pelos protagonistas, tais como: interação com a enfermagem, ajuda nas atividades de rotina, participação em oficinas, conversas com outros técnicos não ganham visibilidade, nem causam impacto sobre a negação/exclusão da produção subjetiva sobrepujada desde o ingresso na instituição. interventor, representado pelo médico que faz a internação, é uma figura pouco perceptivel, distante nos relatos dos "usuários", reforçando o fato de que os contratos com os protagonistas, na sua maioria, não são feitos com ele mesmo, mas com outros mediadores; fora do hospital, com a família e, no hospital, com a enfermagem. A terapêutica predominante corrobora essa distância, pois é baseada na medicação, prescrita e ajustada conforme a produção de sintomas e comportamentos, controlados e avaliados principalmente pela enfermagem. Nesse sentido há também as prescrições "se necessário" ( $\mathrm{S} / \mathrm{N})$ - uma dose complementar e, também, uma 
"flexibilização" para a enfermagem - caso o "usuário" se agite, perambule muito pelos corredores à noite, ou esteja ansioso.

Uma das instituições mais freqüentadas pelos protagonistas traz no seu material de uso diário - fichários, folhas timbradas, propagandas em geral -, o slogan, "Muito mais humanizado". Nesta mesma instituição fui informada de que seus funcionários receberam, pelo menos uma vez, capacitação nesta área. Embora este trabalho não tenha por objetivo discutir diretamente o processo de humanização nos contextos institucionais, vale, ao menos, ressaltar que na prática cotidiana das instituições, a humanização acaba apresentando-se como mais um conceito esbanjado e banalizado sem reflexos concretos na vida dos sofredores psíquicos. Isto se torna ainda mais grave se considerarmos que a humanização é um elemento extremamente importante nos processos de preservação da vida em geral, e da saúde em particular. Senão vejamos o que diz Paulo Freire (1998, p.22): "o humanismo é um compromisso radical com o homem concreto. Compromisso que se orienta no sentido de transformação de qualquer situação objetiva na qual o homem concreto esteja sendo impedido de ser mais".

Se essa idéia de humanização se coaduna perfeitamente com a idéia de (des)institucionalização colocada no âmago da proposta da reforma psiquiátrica, não é o que vivencia o protagonizado, freqüentador de um lugar onde o impedimento parece ser a regra que se operacionaliza através do seu anonimato e da sua pouca visibilidade, da homogeneização do cuidado e da desconexão com seu contexto. A contribuição de Basaglia e Freire vai no sentido de compreender a condição de ser "sujeito", de ser "humano". No entanto, nas instituições psiquiátricas de modo geral, o que se dá é exatamente o contrário, ou seja, aí os indivíduos são sujeitados e desumanizados. Por meio do conceito de pensamento complexo de Morin, é possível falar de sujeitados como todos os que fazem parte desse lugar, uma vez que a idéia recursiva do "tudo o que é produzido volta sobre o que produziu, num ciclo auto constitutivo", vale para os operadores de um projeto que, limitando o diálogo, a negociação, a "unidade complexa" do ser 
humano, mantém-se também limitado de trocas, por si, criativas e enriquecedoras.

A lei gaúcha da reforma psiquiátrica (9.716/RS) assegura que as pessoas em sofrimento psiquico não sofrerão "limitações em suas condições de cidadãos e sujeitos de direitos livres, intemações de qualquer natureza ou outras formas de privação da liberdade". Considerando essa cláusula, diriamos que continuamos em "dívida" com esses sujeitos até agora alijados no interior do circuito oficial de saúde. Embora estejam sempre dando indicativos de seus desejos e potencialidades são, na maioria das vezes, alijados de negociar o seu próprio tratamento e de, com suas experiências enriquecedoras e criadoras de "possibilidades terapêuticas" - ampliar a percepção daqueles que não são sofredores psíquicos, mas que de algum modo, relacionam-se com eles.

Todo o homem tem direito de ser, em todos os lugares, reconhecido como pessoa perante a lei (Artigo $6^{\circ}$. - Declaração Universal dos Direitos Humanos).

\subsubsection{Resistindo e protagonizando espaços: a busca de singularização}

Mais do que o gesto interessa como ele foi recebido. Mais do que a palavra, nos influencia como ela foi ouvida. Mais do que o fato, vale onde, como e quando ele nos tocou.

(Lya Luft)

As trajetórias da atenção à saúde dos protagonistas apresentam muitos pontos em comum e algumas peculiaridades. Se as tensões e resistências presentes nas diversas circunstâncias de busca de atendimento não chegam, em grande medida, a mudar o desfecho dos acontecimentos, na trajetória de João-de-Barro encontramos uma maior variedade de estratégias e arranjos que vão constituir o seu cotidiano, buscando resistir e romper com as normas pré-estabelecidas, presentes nos territórios profissional e institucional. Depois de conhecer o hospital psiquiátrico "por dentro", João-de-Barro passou a lutar por respostas mais condizentes às suas necessidades cotidianas, seguindo dessa forma, o fluxo dos seus 
sentimentos, dos seus desejos e, transpondo, na maioria das vezes, prescrições a priori.

Esse fluxo é dinâmico, modifica-se no decorrer do tempo e gera novas necessidades, novas intensidades, novos afetos que não se encaixam nos territórios anteriores, ou seja, nas ofertas até então disponibilizadas. Nos termos de Rolnik (1989), João-de-Barro procura criar "linhas de fuga", buscando engajar-se em novas formas de territorializar os seus afetos e necessidades. Esse processo é trabalhoso, tenso e de muitos "desencontros" no decorrer da trajetória, visto que os diálogos nem sempre se estabelecem no sentido de uma aproximação entre o desejado pelo protagonista e o captado, ou possível, no circuito.

É ele quem negocia o tratamento no contexto das possibilidades oferecidas nos serviços. Diante de várias alternativas de entrada na rede de saúde, João-de-Barro, que é bastante comunicativo e demandante desses recursos, conhece os lugares e as pessoas que acumulam algum poder nas instituições, direcionando a elas os seus pedidos: lá tem que falar com o fulano, os outros não adianta, ou, lá ninguém resolve nada, tem que ir na Secretaria (órgão hierarquicamente superior) e, quando os serviços não viabilizam sua necessidade, ele recorre à justiça, aliada que, em última instância, pode falar por ele. Sua busca incessante pelos direitos relacionados ao seu problema de saúde faculta que consiga construir vários pontos de apoio nessa rede, tanto em relação as suas terapêuticas mais especificamente, quanto a pessoas que administrativamente possam viabilizá-las: se a gente não insistir, não consegue as coisas, aqui tem gente que precisa muito e não consegue nada, eu vejo isso a todo o momento, mas se eu preciso eu não arredo o pé. Chega a ironizar sua própria condição, quando conta a história de suas conquistas por serviços e atendimentos: como eles sabem que eu tenho uns parafusos a menos na cabeça, eles acabam conseguindo pra mim.

Ele não se cala diante de imposições e impedimentos que possam vir dos profissionais de saúde. Ao contrário, força sempre que possivel 
alternativas não convencionais, como por exemplo, a de ter conseguido um horário especial no Caps já que havia sido afastado de lá, porque os profissionais tinham dificuldade em lidar com ele. Era considerado um "usuário perigoso" para permanecer no local por muito tempo, por isso, ele foi transferido para o primeiro atendimento psiquiátrico da manhã, a fim de que seu médico pudesse manter o vínculo, dando-lhe suporte. Era atendido sempre às sete horas, para que às oito horas, horário de inicio do funcionamento do Caps, já estivesse liberado. Assim foi atendido durante meses, até adquirir "condições" de retornar às atividades diárias desse serviço de saúde.

Discorreremos agora, sobre suas internações no hospital geral. Embora essas internações estejam no final de uma lista de outras tentativas buscadas na rede ambulatorial, a necessidade de cuidados intensivos fazia com que ele buscasse um caminho menos estigmatizante. O Caps é o seu local de referência, freqüenta-o com certa regularidade, usando os demais serviços numa intensidade que the é peculiar, servindo-se deles, particularmente, nos momentos em que os "tormentos" provocados pelo seu sofrimento voltam com intensidade marcante. João-de-Barro parece sair atrás de uma resposta que alivie sua dor, numa incessante busca que, na maioria das vezes, leva a destinos já conhecidos: novas drogas, aumento de dosagens dos medicamentos, encaminhamentos para internações psiquiátricas. Com outro problema de saúde associado a sua situação psíquica e, dependente de uma rede de saúde frágil e pouco articulada, consegue desviar a rota, tendo no hospital geral uma possibilidade de tratamento mais adequado.

Registro abaixo fragmentos que ilustram as sucessivas resistências expressas nessa trajetória:

João-de-Barro estava há dias, ansioso, falando das dificuldades de lidar com um familiar e com a dose dos medicamentos que aumentavam a cada nova consulta. Buscava ajuda diária no Caps que o encaminhou para internação no hospital municipal César Santos. Ali, ele permaneceu por alguns dias, obtendo alta sem, no entanto, ter melhorado. 
Passado um tempo, encontrei sua mãe que fora se desculpar na Coordenadoria Regional de Saúde pelo fato de João-de-Barro ter se descontrolado e causado pequeno dano ao patrimônio físico da instituição. Nesta mesma ocasião, ela contou-me que a equipe do Caps determinara que seu filho se internasse no Bezerra, pois estava muito confuso. Caso não cumprisse a determinação, não mais poderia freqüentar aquele serviço. Segundo sua mãe, Joãode-Barro recusava-se a voltar àquele hospital.

Soube, mais tarde, através do seu pai, que o Caps chegara a enviar uma ambulância para conduzi-lo ao Bezerra, mas ele, além de não aceitar, e por causa disso, indispôs-se com a equipe. Por isso, estava procurando um outro atendimento no Posto de Atendimento Médico - PAM. Resolvi segui-lo em seu percurso. Encontrei-o na saida da Secretaria Municipal de Saúde, onde estivera visitando as gurias da coordenação de saúde mental com o intuito de queixar-se da conduta que os profissionais adotaram para com ele. Antes disso, no PAM, ele fora atendido pelo médico e pelo administrador com quem quase sempre consegue remédios não disponiveis ou em falta na farmácia pública.

João-de-Barro continuou as buscas à procura de um espaço que pudesse aliviar a sua dor. Conseguiu, então, a segunda internação consecutiva no hospital geral, desta vez no hospital São Vicente.

Encontrei-o no hospital aguardando leito em uma enfermaria lotada. Recebeu-me de forma receptiva, contou-me dos exames já realizados e dos que ainda seriam feitos. Mostrava-se tranqüilo e esperançoso, pois o médico lhe assegurara que não sairia de lá enquanto não estivesse em boas condiçōes. Embora as condiçōes fisicas da enfermaria não fossem das melhores pela grande quantidade de "usuários" para o pequeno espaço, Joãode-Barro preferia essa situação escolhida por ele, à situação do hospital psiquiátrico para onde se negava a ir, apesar da orientação do serviço especializado.

Estivemos juntos várias vezes, durante os trinta dias em que permaneceu internado. Seu quarto ficava no piso térreo, perto da recepção que tem vigilância durante 24 horas. Tratava-se de estratégia do médico, pois João-de-Barro era considerado um "usuário" agitado nas instituiçōes psiquiátricas e, apesar disso, estava ali, no hospital geral. Mesmo que o diagnóstico que o levou à internação estivesse ligado a questões neurológicas, o que justificava a internação em hospital geral, não deixa de ser surpreendentemente positiva esta internação, já que existe uma resistência explicita da parte de administradores e outros profissionais dos hospitais gerais em aceitar pacientes com as caracteristicas dos nossos protagonistas. Afinal, ele não estaria lá, não fosse a decisão do médico de propor uma estratégia adequada, colocando-o em um local mais protegido, com acompanhamento permanente de um familiar.

Outra vez, encontrei-o sonolento, esforçando-se para manter-se acordado, pois não podia fazer desfeita para a visita. Neste dia, queixou-se mais uma vez dos profissionais que tratavam dele antes da internação. Agora era a visita deles que não ocorrera e que João-de-Barro gostaria de ter recebido, especialmente daqueles com quem mantinha um vínculo mais consistente. Afinal, nesse momento de fragilidade era natural que ele 
desejasse a presença dos terapeutas que o acompanharam durante um longo periodo. Apesar de tudo, ele não deixa de observar: aqui a gente é muito bem tratado, eles cuidam mesmo, tratam a gente com delicadeza, a gente até estranha.

$\mathrm{Na}$ verdade, ele busca na internação outras relações, outros vínculos, mesmo que provisórios. Dias antes da alta, encontrei-o conversando com uma pessoa internada - era um homem que seria submetido a uma cirurgia cardíaca - e seus acompanhantes. João-de-Barro parecia muito bem, sereno, sorridente e crítico. Falava de forma descontraida sobre seu tratamento, fazendo considerações negativas a respeito de como havia sido tratado até aquele momento, tendo o Caps como referencial. Dizia-se particularmente feliz porque logo receberia alta, tendo escapado da internação no Bezerra; as doses de remédio estavam sendo diminuídas e, não estava mais cambaleante. Em outras palavras, podemos dizer que João-de-Barro referia-se a um momento do tratamento em que se sentiu tratado como sujeito: foi ouvido, suas queixas foram valorizadas, conviveu com pessoas com outros problemas de saúde, sentiuse cuidado; enfim, viveu a experiência de um lugar que propiciou-lhe a serenidade necessária para combater o "turbilhão" que o atormentava.

Além disso, seus arranjos demonstram o quanto o contato com o outro, com o "não louco" é salutar, contradizendo um certo jeito de olhar e viver a questão do sofrimento psíquico dominante nos serviços de saúde. As solicitações que faz, como por exemplo, a de ser envolvido no próprio tratamento, juntamente com sua família, de um modo mais participativo, e as resistências que apresenta a práticas impositivas e restritivas, que no seu jeito de entender não the trazem nenhum benefício são expressões do desejo de inserção, de participação, de co-produção, de se sentir pertencente a um grupo - familiar, de amigos, do "pessoal do Caps" - e de pertencer também a outros grupos que lhes possibilitem outras identificações, outros lugares. No interior dos limitados "espaços terapêuticos" oferecidos pelos serviços, nosso protagonista conseguiu forjar um novo jeito de se cuidar, no que foi correspondido. Aparece também aí profissionais que compreendem de outra forma e, conseqüentemente, 
trabalham de outro modo, com o sofredor psíquico. Ou seja, trabalham estabelecendo relações diferenciadas e, quem sabe, assim fazendo, podem contribuir para romper com olhares preconcebidos e preconceituosos de outros trabalhadores da saúde e de outras pessoas ligadas a estes espaços, no sentido de apontar caminhos alternativos no interior de instituições que relutam em aceitar "pacientes psiquiátricos".

Contrariamente ao que é temido pelos hospitais gerais, João-deBarro não apresentou nenhum problema com o cumprimento das regras estabelecidas na internação: não provocou nenhum dano material, respeitou a proibição do cigarro (deixou de fumar durante a internação), permaneceu no quarto, ouvindo seu radinho de pilhas e usufruindo as conversas com as visitas e com o outro internado no mesmo quarto, saindo apenas para comprar balas e refrigerantes no bar do hospital. Pôde viver um outro território de fundamental importância no resgate de sua saúde mental, território protagonizado por ele, mesmo na contra-mão da sua instituição de referência.

Nosso protagonista imprime em sua trajetória o sentido da reforma psiquiátrica - ainda não assimilada por muitos trabalhadores e instituições de saúde mental -, e busca conexões na sua rede para um tratamento mais qualificado. Procura balizar-se pelo bom senso e preservação de sua autonomia, usando o circuito da maneira que julga a mais adequada. Foi persistente, apesar das tensões advindas, por exemplo, da reação de profissionais que se mostraram, muitas vezes descontentes, porque Joãode-Barro discordou de suas condutas em relação ao tratamento, e negociou com outras pessoas da rede, a fim de ganhar força diante da situação, e assim, explorar outros territórios de potências singulares. Nos termos de Morin, ele desorganiza as condutas dos profissionais que, ao contrário do que deveríamos esperar de qualquer instituição de saúde, sobretudo de serviços substitutivos, apresentam dificuldades em aceitar essa desorganização e reorganizar-se a partir de uma reflexão sobre essas iniciativas e resistências. A tendência dos serviços é manter um princípio de ordem e de certeza baseado, fundamentalmente, no conteúdo do 
"desviante" (de um "usuário" reduzido à taxionomia, equivalente a um sentido uno), buscando a inserção, a normalidade sem passar pela singularidade da vida. Em outras palavras, as instituições de saúde parecem não tolerar o fato de se constituírem em lugares de instabilidade e incertezas permanentes. Fazendo isso, impossibilitam a entrada da subjetividade, das singularidades, isto é, do múltiplo de cada sujeito, da desorganização expressa no turbilhão do processo do adoecimento, que também cria possibilidades de organização, se tomarmos essa dialógica como subsídio para os modos de operar a saúde mental.

\subsubsection{O retorno ao Hospital como álibi à falta de outros recursos}

O tratamento de cada usuário deverá ser direcionado no sentido de preservar e aumentar a autonomia pessoal (Declaração da ONU, principio 9, item 4, 1991).

Eles próprios querem se internar. Eles manipulam para conseguir o que querem. É assim que alguns profissionais e familiares justificam o retorno dos protagonistas a instituições anteriormente refutadas. Entretanto, acompanhando determinados momentos da trajetória, por dentro do circuito institucional, pude perceber o que tem sido o desafio de um cotidiano de buscas de estratégias para suportar o fluxo existencial de tormentos, ansiedades e dar vazão a desejos e necessidades.

A dificuldade dos protagonistas em encontrar respostas novas para novas exigências que surgem com a melhora da situação mais crítica, tem se apresentado como o principal determinante desse retorno. A não visibilidade da saúde-doença como processo, no sentido desenvolvido no inicio dessa tese, dificulta, senão ofusca a constituição da pessoa, da complexidade dos fenômenos da existência, desconsiderando que essa condição humana envolve as mais diferentes feições do sujeito e do seu contexto. Tais aspectos não vêm à tona na relação do sujeito com os profissionais de saúde, caindo na circularidade tradicional do circuito, a saber: novas exigências equivalem a novas internações, que equivalem a 
novas drogas; ou seja, um circuito tipicamente "psiquiátrico". Lobosque (2001, p.88) afirma que os serviços de saúde deveriam gradativamente, após passada ou amenizada a crise, ir "retirando o sofrimento psíquico do âmbito mais estritamente sanitário, para inscrever com delicadeza e cuidado a loucura na construção cultural e social da qual tradicionalmente tem sido alijada".

A trajetória de João-de-Barro sempre foi marcada por tensões relacionadas ao seu lugar social, tanto na relação com a família, com quem reside, como em relação ao desempenho de seu papel de pai, de homem e de trabalhador que passou por profundas transformações com a chegada do adoecimento psíquico. Essas mudanças, no entanto, características de uma nova identidade que o destituiu do papel de "homem da sua idade", parece nunca terem sido tomadas como centrais ou constitutivas do tratamento, embora as interações conflituosas em torno delas, estivessem permanentemente em cena, seja através das dificuldades com seu pai, contrário a que João-de-Barro tomasse medicamentos e, para impedi-lo de tomar vivia dizendo, "isso é puro placebo"; seja pelo impedimento de um convivio maior com o filho; seja no silêncio de sua ex-mulher em relação ao que acontecia com a vida da criança (ocultando, por exemplo, que o menino freqüentava a creche e que apresentava dificuldades de relacionamento com outras crianças), ou ainda, nas tentativas frustradas e solitárias de trabalhar, morar e retornar à vida de estudante.

A sua circulação por dentro do circuito aumentava à medida que essas situações ganhavam evidência na sua trajetória, numa busca intensiva de respostas para esses conflitos. Um investimento quase sempre sem o retorno esperado, pois suas buscas esbarravam constantemente no enquadre dos valores profissionais, sob uma perspectiva fortemente normativa. Essa redução/fragmentação impedia-o de aprofundar o sentimento relacionado a sua historia pessoal, familiar e social, aumentando, significativamente, o tensionamento e o risco de novas crises. Os profissionais/serviços, sob a alegação de permitir o acesso ao sistema de saúde, só faziam aumentar, em decorrência dos métodos utilizados, a 
exclusão social, tornando cada vez mais distante à possibilidade de reconstrução identitária que the possibilitasse resgatar habilidades, autonomia e desejos. Trago alguns fragmentos relativos aos últimos episódios registrados sobre João-de-Barro nesta pesquisa, que ilustram o que estamos discutindo.

Há alguns meses João-de-Barro vinha manifestando dificuldade na convivência familiar, por sentir-se tolhido na realização de seus desejos e impossibilitado de tomar determinadas iniciativas. Selecionava, com critério, aquilo que podia levar ao conhecimento deste ou daquele parente, pois, caso explicitasse determinadas posições e/ou condutas, o risco de ir "para o olho da rua" aumentava. Embora obtenha o apoio da maioria dos familiares, eles não se predispõem a enfrentar a relação com um dos seus membros, conflituosa com todos os demais há muito tempo. Os outros irmãos ganharam independência e sairam de casa, estando, portanto, mais afastados dessa problemática, que no momento o afeta. É ele mesmo quem relata:

\begin{abstract}
O meu pai bebia e surrava e deixava nós sem comida. Eu e meus irmãos passamos fome. Saiamos também juntar ferro, aço, alumínio para amumar dinheiro pra comprar comida. Os meus irmãos casaram e sairam de casa [...] de tanto sofrimento que passei resolvi sair de casa (conta suas andanças por Porto Alegre e pelo Rio de Janeiro).

Ele (o pai) fala todo dia que eu tomo um monte de placebo. Ele não entende a minha doença. Há uns quinze dias, ele escondeu todos os remédios e me trancou no quarto. Fiquei mais de uma semana nessa situação. Eu já tava entrando em crise de novo. A sorte é que a mãe conseguiu pegar um pouco de cada remédio e quando ele se distraia ela me alcançava pela janela do quarto com um copo de água. Ai eu resolvi que ia tomar uma providência. Combinamos eu e a mãe, eu pulei a janela e fui com ela na delegacia de polícia fazer uma ocorrência que meu pai tava me mantendo em cárcere privado e não me deixando tomar o remédio. Na hora o delegado me mandou com uma cartinha falar com o juiz. Fui lá e o juiz me disse: vamos fazer o seguinte: você não vá pra casa agora, vá ao Caps. Deixe só a tua mãe ir que eu vou mandar um oficial de justiça agora na sua casa com ordem de trazê-lo aqui. Se ele não quiser vir, o oficial terá ondem de chamar a policia para auxiliar.
\end{abstract}

João-de-Barro, revelando muita tristeza, conta esse episódio, acrescentando que não foi preciso a intervenção da polícia. Depois disso 
não trancou mais, mas continua incomodando daquele jeito que a senhora viu. Eu tenho dois problemas sérios na minha vida, um é esse e outro é com o meu filho. Eu dou a pensão e ela (ex-esposa) não compra as coisas pra ele, porque ela tem outros filhos. Eu queria ficar mais perto dele, até trazer ele pra morar comigo, mas aqui em casa ele não pode dormir nenhuma noite porque o velho acha que ele vai ficar morando.

Percebendo que chegava ao limite de suas forças emocionais, e temendo vitimar um familiar, resolveu buscar alternativas para mudar-se da casa dos pais. O fez escondido de seu pai, pois se ele soubesse de suas intenções o impediria de voltar a sua casa, caso o plano desse errado; ainda assim, obteve o apoio da mãe na procura de um lugar onde pudesse morar. $\mathrm{Na}$ verdade, sua mãe tentou organizar uma alternativa em que ela mesma pudesse acompanhá-lo na mudança. Entretanto, questões financeiras impediram esta saída. Depois de uma semana tumultuada em que João-deBarro percorreu vários serviços de saúde na tentativa de encontrar "alguém" que pudesse ajudá-lo a enfrentar essa situação e, já em estado de agravamento psíquico, ele conseguiu explicitar três possibilidades de reorganização de sua vida:

\begin{abstract}
Eu preciso sair daqui antes que aconteça alguma coisa mais grave comigo ou com outra pessoa. Quero fazer uma experiência de morar em outro lugar, pode ser a pensão da dona Filó (onde já havia morado antes de adoecer), ou outro lugar que eu possa pagar um valor até $R \$ 200,00$. Aí eu tomo os remédios no Caps durante o dia e o remédio da noite eles (profissionais) me dão, já separado em um pacotinho.[...] Eles ficam com o controle lá e eu me comprometo de ir todo o dia. A segunda alternativa é internar no São Vicente (hospital geral) e a última, se nenhuma das outras der certo, é me internar em Caxias, na Clinica Psiquiátrica Paulo Guedes.
\end{abstract}

Suas propostas foram discutidas com alguns familiares que resistiram, inicialmente, em apoiá-lo. Diziam que deveria relevar certos atritos em casa, mas, por outro lado, compreendiam que era difícil para ele assumir tal conduta. Por isso, opinaram que deveria internar-se no hospital psiquiátrico da cidade. A Clínica Paulo Guedes ficava longe, diziam, o que dificultaria as visitas, além de lembrarem de que a experiência de João-de- 
Barro na referida clínica não tinha sido positiva: havia restrições com os pertences pessoais, era complicado telefonar para lá e a comida, e aí ele próprio concorda, era ruim demais.

Ouvidos os familiares, mesmo assim, João-de-Barro resolveu pesquisar lugares. Apoiado e acompanhado de uma profissional do Caps, ela investigou alternativas de lugares e viabilizou contatos. As primeiras tentativas foram frustradas, aumentando sua ansiedade. Chegou até a encontrar uma pensão economicamente viável. Entretanto, as exigências burocráticas - deveria deixar o cartão e a senha do banco com o proprietário da casa -, expressavam a desconfiança sobre sua capacidade em gerir sua vida material, deixando-o humilhado e fazendo-o desistir desta alternativa. Apesar do surgimento de uma outra pensão, João-de-Barro foi buscar uma internação no hospital geral, pois seu estado emocional tinha piorado muito, levando-o a idéias recorrentes de morte. Ele próprio reconheceu que não tinha mais condições psicológicas, naquele momento, para enfrentar a situação. Na verdade, a internação representava a sua "rendição", mesmo que por um periodo, em uma história de lutas e conflitos nas relações e de muitas perdas que a doença Ihe trouxera.

Ele sabe que não há uma regulação por parte do município em relação às internações psiquiátricas nos hospitais gerais e que, para entrar nesses locais, só por outra via, isto é, por outro tipo de problema de saúde, ou pela emergência. Intensificou sua "via-sacra" por vários serviços do circuito de saúde que poderiam viabilizar essa estratégia. Tentou consulta com o clínico geral e com o neurologista, mas não conseguiu escapar de ter de entrar na agenda.

Foi orientado pela secretária do neurologista a procurar o serviço de emergência do Hospital São Vicente de Paulo. Pediu-me que o ajudasse a viabilizar essa internação, indo com ele até o Cais - Centro de Atenção Integral à Saúde -, na esperança de conseguir uma vaga mais rápido, uma vez que eu conhecia algumas enfermeiras ali e ele sabia disso. Em outras vezes, fui mais discreta, mas agora resolvi atender o seu pedido, pois sua 
ansiedade e risco de morte pareciam-me cada vez mais acentuados. De fato, ali João-de-Barro foi atendido, tendo eu mesma participado de parte do atendimento, quando ele solicitou: Bernadete me ajuda explicar porquê tô muito nervoso e não consigo me comunicar direito. Falava alto demais, sem pronunciar metade das palavras. A estratégia que ele traçara para aquele lugar era a seguinte: chegar até a médica, obter o laudo do SUS com o código cinco - código que caracteriza emergência, obrigando o hospital a atender - e com isso, dar entrada na emergência do HSVP. A médica atendeu, encaminhou-o para internação, mas quando a enfermeira do Cais contatou o serviço de emergência do HSVP, foi informada de que o hospital não poderia atendê-lo. A sugestão foi a de encaminhá-lo diretamente ao hospital psiquiátrico, resposta que corrobora o que já dissemos anteriormente, isto é, que ao chegar em crise nos serviços de saúde da cidade, os sujeitos são prontamente endereçados à internação psiquiátrica. No Cais pediram que ele voltasse mais tarde ou no dia seguinte para fazer nova tentativa de internação. Mais uma vez voltou frustrado e tenso para casa. Conversei longamente com ele e seus familiares que ficaram de acompanhá-lo na emergência mais tarde, ou no outro dia. Ele sabia que se chegasse com o laudo de internação, alguém teria de atendê-lo, mas também sentia que sua situação requeria um tratamento mais intensivo ${ }^{72}$. Naquela noite, João-de-Barro ingeriu quantidade tóxica de medicamentos, indo para a emergência em condições graves.

Saiu da emergência com orientação de internação psiquiátrica, mas não aceitou o encaminhamento, alegando que consultaria outro médico (que já estava agendado, e com quem tratava um outro problema de saúde) que em outras ocasiões já o internara no hospital geral. Não foi o que aconteceu. O médico alegou não encontrar justificativa em sua especialidade para tal procedimento, e solicitou que ele retornasse ao seu psiquiatra e ao Caps.

Inconformado com o desfecho de suas buscas, nosso protagonista voltou ao psiquiatra, pedindo a internação na Clinica Psiquiátrica Paulo

${ }^{72} \bigcirc$ que não significa que devesse ficar internado. Requeria um acompanhamento continuado e intensivo. 
Guedes (Caxias do Sul), a última das alternativas por ele elencadas. O psiquiatra, porém, disse que seu caso não era de internação, orientando-o a manter o tratamento ambulatorial. Diante disso, João-de-Barro resolve pressionar um outro espaço de poder, recorrendo à coordenação da política de saúde mental. Aí, ele obteve sucesso: o médico não disse nada, só me deu o laudo, mas todo o mundo lá do Caps ficou chateado comigo por eu querer ir pro hospital e ainda pra um hospital longe daqui. Lá é mais longe, mas é aberto, tem mais liberdade, posso ficar no pátio, posso ficar com a carteira de cigarro,... Estou com uma expectativa grande, quero e não quero.

Inicialmente, o que ocorreu com João-de-Barro parece uma grande contradição diante de sua trajetória de busca por direitos e autonomia, mas, neste caso, ser cuidado em um hospital, tornava-se uma saída menos penosa do que suportar a continuidade da vida em casa dos pais, ou a impossibilidade de encontrar um novo lugar para morar. Esse "lugar" pode ser compreendido no sentido que the é dado por Augè (2001), como um espaço identitário, subjetivo, mais do que propriamente uma mudança do espaço físico. Sua motivação para a internação não era a expectativa da melhora, tanto que negou as dificuldades por que passaria em uma internação psiquiátrica: isolamento, troca de medicamentos, subordinação; mas relacionava-se à necessidade de um afastamento necessário para "aliviar a cabeça", era como um suporte social temporário.

Mesmo entendendo a trama complexa que produz e provoca esse sofrimento humano, e todas as limitações do campo profissional para o alivio e a reestruturação dessa condição de vida, é preciso questionar que possibilidades essas interações profissionais produzem em termos de um lugar social suportável, que permita o desenvolvimento da vida desse sujeito, como observa o nosso protagonista: se é um lugar pra ajudar a resolver os problemas da gente, porque só tratam do mesmo jeito? Ou, o que relatou uma outra pessoa no momento de sua internação: eu não espero nada daqui, porque já sei que é sempre a mesma coisa!

Esta observação é reveladora da intensidade da relação afetiva que João-de-Barro mantém com o Caps - o espaço institucional que o acolheu, 
possibilitou encontros e vínculos, supriu necessidades de muitos momentos -, que não conseguiu responder melhor e sem tantos limites às situações que esse "desejo de vida" tem colocado no seu cotidiano.

Ele gerencia sua vida, suas coisas, mas quer mais, porque pode mais e não quer ser balizado pelo seu adoecimento, que é grave e precisa de cuidados, mas, o que ele vem recebendo (mais especificamente a terapêutica medicamentosa) não necessita de um serviço de atenção diária. Então, estabelece-se com ele e, entre ele e o serviço, uma relação de poder marcada pelo conflito. Isto é, se por um lado, os profissionais têm poder para apontar um caminho a ser seguido, por outro, ele também mobiliza forças nas relações que construiu com os serviços, e agrega um poder que, às vezes, consegue fazer frente a determinadas condutas dos profissionais. Esse é um "sujeito em sofrimento psiquico contemporâneo" que viveu o processo de internação psiquiátrica nos últimos cinco anos de sua vida, sentiu-se violentado, e violentou como resposta às agressões sofridas, viveu o serviço aberto e incorporou aspectos de um discurso que fala de direitos humanos, de participação e democracia. Fez uma bricolagem e hoje dá um sentido para tudo isso, através do que expressa e procura viver, mas confronta-se com o que sobrevive no cenário dos serviços que, ao invés de dar-Ihe voz ativa e condições de posicionamento e contratualidade neste jogo de forças exigido no cotidiano, faz predominar uma "cultura no singular", parafraseando Certeau (1995) que, sob artificios mais sutis, continua violando a condição de sujeito de direitos e de "usuário" de serviço de saúde mental.

Embora sempre hão de existir cartografias desconhecidas quando se trata da subjetividade, outro desfecho só será possivel, parece, se essa estiver no eixo central da atenção à saúde mental, havendo investimento no processo de reconstrução das trajetórias dessas pessoas, fortalecendo as relações que operam a favor da emancipação, da autonomia, de uma identidade que não seja balizada pela submissão, pela perda das referências de sujeito, de pai, de trabalhador, de homem, mesmo diante do sofrimento psiquico grave. Caso contrário, a internação psiquiátrica continuará sendo o 
álibi para a falta de uma outra compreensão que rompa com uma forma dominante de entender e lidar com o sujeito na sua condição de saúdedoença mental.

Ainda que muitas questões tenham ficado em aberto, posso dizer que "viver o circuito" de atenção à saúde mental de Passo Fundo, buscando a compreensão, a partir de quem dele usufrui - "os usuários" -, foi revelador da distância tamanha entre o que se apregoa e o que acontece no momento de acessar esses serviços. Como revelei no início desse capítulo há um contraste entre um código moderno e humanizado que perpassa os discursos e os projetos institucionais e outro conservador, presente nas interações cotidianas entre quem usa e quem opera os serviços. O primeiro não consegue romper com as práticas que, na sua maioria, desvalorizam e que fazem desaparecer o sujeito do sofrimento. 


\section{CAPÍTULO VI - A METAMORFOSE DO SINGULAR AO PLURAL}

Como já apresentamos nas diversas experiências vivenciadas na cidade, os sujeitos da pesquisa nos mostram caminhos entre o singular e 0 plural (no sentido de Certeau). Para esse autor, uma questão de fundo da cultura singular "está na maneira como respiramos, nas idéias, na pressão autoritária de uma determinação social que se repete e se reproduz [...]. $\mathrm{Na}$ análise cultural, o singular traça em caracteres cifrados o privilégio das normas e dos valores próprios a uma categoria" (CERTEAU, 1995, p.227). Ainda sob o predomínio de uma cultura singular há nas entrelinhas dessas trajetórias outras práticas que conclamam incessantemente por transformações, procurando vias para escapar das determinações sociais, expressando a busca de uma cultura no plural, embora nem sempre possam vencer as imposições que atravessam suas inter-relações.

Analisaremos a seguir, duas situações que refletem o caráter dialógico da realidade como um jogo incessante, incerto e interdependente.

\subsection{A promotoria e a defensoria pública como estratégias de acesso à rede oficial de saúde e de ampliação de direitos humanos}

Nos itens precedentes procurei mostrar algumas das interações que marcam o circuito de atenção à saúde. Em diversos momentos e, sob diferentes formas, percebi que na base de muitas relações sobressaiam-se violações dos direitos humanos como, por exemplo, nas internações forçadas, no uso abusivo de medicamento, na falta de credibilidade que se tem em relação ao que diz o sofredor psíquico e na expressão dos sentimentos dos sujeitos, na destituição de seu poder, entre tantas outras.

Trata-se de um processo complexo de violação dos direitos humanos, sobretudo pela naturalização do "doente mental" enquanto um sujeito incapaz de conviver em sociedade, possibilitando a formação de uma cultura na qual um diagnóstico condena este sujeito à estigmatização, 
justificando inclusive a perda dos seus direitos civis e sua tutela aos técnicos e responsáveis.

Registrar essas violações não é tarefa fácil. São situações vividas em momento delicado para o sofredor psíquico e relacionadas diretamente aos que detém o poder de "cuidar", que é um poder "absolutamente superior" na relação, conforme relatou uma depoente:

\begin{abstract}
o que eu vivi lá foi desumano, tive que conviver com gritos de todo o lado, porque diálogo não existe. A gente tem que ficar sem roupa, enrolado em uma toalha às seis da manhã gemendo de frio, esperando o banho, porque se tu demora pra tirar a roupa, eles (funcionários) te arrancam na marra, além de te obrigarem a usar todas as roupas do hospital: aquelas roupas que não são nem passadas a ferro, nem desinfetadas, sendo que tem gente com sarna, que eu vi, e as roupas são todas jogadas no mesmo lugar. E quanto mais tu fala ou reclama, mais tu recebe injeção. Eu passei a receber uma injeção atrás da outra porque me neguei a usar as roupas do hospital e não fiquei quieta com os gritos da (profissional). Os pacientes do SUS são tratados como bichos. Eu tenho muito medo de falar, porque se eu denunciar e aparecer meu nome, tenho que ficar imune à internação, porque depois de ter vivido isso, acho que eles podem qualquer coisa... e quem me garante que eu não vou ter que parar lá de novo.
\end{abstract}

As instituições de saúde são, de modo geral, acompanhadas e avaliadas regularmente por equipes específicas coordenadas pelas Secretarias Estaduais de Saúde ${ }^{73}$. E os hospitais psiquiátricos, de modo especial, são vistoriados anualmente ou, sempre que há denúncia em relação ao seu funcionamento. A avaliação centra-se principalmente, nas condições técnicas de funcionamento, envolvendo também os "usuários". Ainda que essas vistorias colaborem de forma positiva, como de fato o fazem, na adequação das condições físicas e terapêuticas dos hospitais é difícil, pelo menos na realidade de Passo Fundo, para a equipe que avalia, apreender determinados aspectos relacionais do cotidiano. Os "usuários" que se sentem lesados ficam, geralmente, temerosos em verbalizar esse sentimento e, como esses atos são sutis, capciosos e acontecem nas interações diárias entre funcionários e "usuários" tornam-se dificeis de serem relatados em uma avaliação. Por isso, estes mecanismos avaliativos

${ }^{73}$ Equipes que desenvolvem o PNASH/Psiquiatria - Programa Nacional de Avaliação dos Serviços Hospitalares/Psiquiatria do Ministério da Saúde. 
parecem insuficientes para assegurar a garantia do direito dos "usuários", cobrando a responsabilidade pelo cumprimento da legislação vigente, sobretudo ao que concerne a uma política de saúde mental que respeite a dignidade humana.

Se, por um lado, há uma forte tendência a práticas restritivas do direito à saúde no campo relacional, por outro, existem inserções positivas no interior dessas trajetórias que permitem enfatizar aspectos voltados à ampliação destes direitos, pelo menos da perspectiva político-administrativa. Em outras palavras, quando se trata de resposta ao acesso a alguns bens e serviços de saúde - medicamento, por exemplo -, os mecanismos de proteção e atendimento funcionam melhor.

Cabe assinalar que a Constituição Brasileira de 1988, - a "Constituição Cidadã" - confirmou as premissas alinhadas na "Declaração Universal dos Direitos Humanos", abrindo caminho para a reafirmação desses direitos. No artigo $1^{\circ}$, apresenta os fundamentos do Estado, entre os quais a cidadania e a dignidade humana. No artigo $5^{\circ}$, a Carta Constitucional assegura que "todos são iguais perante a lei, sem distinção de qualquer natureza, garantindo-se aos brasileiros e aos estrangeiros residentes no País a inviolabilidade do direito à vida, à liberdade, à igualdade, à segurança e à propriedade [...]". Percebe-se através dos múltiplos incisos desse artigo, bem como em todo o texto constitucional, o reconhecimento desses direitos fundamentais que se constituem em objetivos fundamentais do Estado.

A legislação e o conjunto de documentos de proteção - Declaração Universal dos Direitos Humanos, Pacto internacional de Direitos Econômicos, Sociais e Culturais, Programa Nacional de Direitos Humanos correlacionam os direitos humanos com o desenvolvimento social, político e econômico que amplia as possibilidades de desenvolvimento humano em todas as suas dimensões. "Direitos Humanos são universais, indivisíveis e interdependentes e exigem uma ação e um compromisso positivo do Estado e uma complementar atuação da sociedade civil" (www.conferencia.direitos.org.br). Se não for assim, perde-se a 
complexidade dos problemas humanos e com ela "a compreensão da vida, dos sofrimentos, dos desamparos, das solidões, das necessidades não quantificáveis. Tudo isso contribui para a gigantesca regressão democrática, com cidadãos apartados dos problemas fundamentais [...]" (MORIN, 2002, p.110).

Podemos observar avanços nesse domínio não apenas na legislação, mas também no uso e disponibilização do acesso a mecanismos institucionais de garantia a esses direitos. Nesse sentido, registramos no circuito de atenção a saúde, instituições "apoiadoras" como a Promotoria e a Defensoria Públicas, conquistando visibilidade nessa rede, pelo desenvolvimento de estratégias de proteção à cidadania, assegurando aos "usuários" acesso a determinados recursos.

Contrastando com o artigo 196 da Constituição Federal no qual a saúde é entendida como um "direito de todos e dever do Estado garantido mediante políticas sociais e econômicas [...] e ao acesso universal e igualitário às ações e serviços para a promoção, proteção e recuperação", um dos nossos protagonistas guarda "registros" - receitas médicas, atestados que descrevem a doença e tratamento, pedidos de exames, documentos judiciais -, que marcam os momentos em que sofreu ameaças a sua dignidade ou teve obstruído o acesso a recursos de sua necessidade. $A$ exemplo de muitos outros "usuários" do sistema de saúde do município, conforme pudemos analisar nas reportagens de um jornal da cidade ${ }^{74}$, e diante da inconformidade com a violação de seus direitos, João-de-Barro recorre à Promotoria ou Defensoria Públicas para obter informações e orientações. Sabe que os "doutores da lei" respeitam a sua condição de "sujeito de direitos", ouvindo-o e encaminhando cada uma das suas reivindicações, conforme exemplos abaixo descritos:

\footnotetext{
${ }^{74} \mathrm{O}$ "Diário da Manhã é um jornal diário de circulação regional, integrado a uma rádio que desenvolve programas interativos com a população local, quando "denúncias" dessa natureza tomam-se freqüentes. Esses meios de comunicação são os que mais propagam essas informações na comunidade, chamando os "atores institucionais responsáveis" para responder às questões. Em muitos casos a Promotoria e a Defensoria também são solicitadas para "acompanhar e esclarecer" os fatos.
} 
João-de-Barro tentava há dias marcar um exame que havia sido solicitado para diagnosticar suas incessantes dores de cabeça. Ficou debatendo-se durante um bom tempo entre a Secretaria Municipal de Saúde e o Estado, porque um dizia que a responsabilidade pela marcação do exame era do outro. João-deBarro até tentou obter um documento de cada um deles, no sentido de que, por escrito, afirmassem suas não competências para a marcação do referido exame, mas não conseguiu: eles não me deram, porque sabem que são responsáveis. Diante disso, recorreu à Promotoria de Justiça do Estado. No Fórum, foi prontamente atendido pelo promotor que oficiou a Secretaria Municipal de Saúde, informando da urgência de realização do exame devido à gravidade da situação de saúde de João-deBarro. Mas, vinte dias passados deste ato e não tendo o nosso protagonista sido atendido, encaminharam-no à Defensoria Pública que abriu processo judicial, solicitando "tutela antecipada". Alguns dias depois, o juiz intimou o Estado a cumprir o solicitado. Como em todos os momentos desse percurso, foi o próprio João-de-Barro quem levou a intimação ao responsável pela $6^{\text {a }}$ Coordenadoria de Saúde, quando então, teve seu exame agendado para o dia seguinte.

Seguindo as mesmas dificuldades, João-de-Barro enfrentou a obtenção de remédios que eram fornecidos pela Secretaria Municipal de Saúde, através de uma farmácia particular, mas cujo fornecimento havia sido suspenso devido à troca de gestor. O seu esforço para conseguir tais medicamentos contrastava com a passividade dos profissionais do serviço por ele freqüentado, que transferiam a responsabilidade para a familia: a familia dele não toma nenhuma providência. Acompanhando a trajetória percebi que o paradoxo era ainda maior. Soube, pelo próprio protagonista, da "orientação" que recebera no serviço de saúde: ela (uma profissional) quer que eu entre na justiça contra os meus irmãos por causa dos remédios, mas como que eu vou fazer isso! São meus irmãos e de mais a mais receber o remédio é um direito meu! Ela quer passar pra familia, para que a familia assuma a compra, mas cada um tem os seus compromissos e se eu começar a brigar com meus irmãos, o que vai acontecer comigo? Sem um processo de interlocução 'razoável' para um cidadão-doente, mais uma vez ele arranja outra via, ou uma outra voz para fortalecer seu pedido: fui na Defensoria e eles me deram a lista de papéis. Já consegui todos e na segunda-feira, vou sair às cinco da manhã para pegar uma ficha pra doutora fazer o processo.

As estratégias de João-de-Barro são bastante sofisticadas. Ele próprio acessa as pessoas dessa rede, solicitando, por exemplo, que os documentos sejam detalhados para "justificar" a sua necessidade, evitando que se requeira, sejam refeitos, como já aconteceu uma outra vez. Argumenta em seu próprio favor, sempre embasado no direito à saúde, envolvendo todos os órgãos a que compete determinado procedimento, e comenta: eu faço mesmo. É meu direito, quem sabe um dia eu não precise 
mais disso. Mas hoje, quando não vejo outro jeito, procuro a justiça e comento com as pessoas que encontro e que percebo que não conseguem para fazer o mesmo. A justiça não é contra nós.

Essas situações fazem parte do cotidiano do promotor e dos defensores públicos do município que cuidam das questōes relacionadas à saúde e são a "melhor escuta" para os "usuários", quando as políticas não são garantidas pelos órgãos executivos. $O$ Promotor explicita como essas informações chegam à promotoria e como estabelece as relações com o circuito de saúde:

Há um grande número de pessoas que chegam aqui, diariamente, ou telefonam solicitando audiência para resolver problemas de intemação, medicamentos ou exames (mostra-me uma série de documentos referentes a esses pedidos). Vou te dar um exemplo: quando as pessoas necessitam de medicamentos e não conseguem na farmácia do PAM (municipal), algumas vezes vão à rádio, outras vezes vão lá com a coordenadoria - a coordenadoria não resolve porque o medicamento é de base do município -, ai para eles irem até a defensoria pública é mais demorado, pois há necessidade de uma série de documentos para abrir processo, então eles vêm aqui. Os pedidos são feitos por telefone ou por oficio para o municipio. Nesses casos o município normalmente autoriza.

Tem épocas que aparecem com mais freqüência, pessoas buscando internação psiquiátrica. Eles procuram a coordenadoria ou a secretaria municipal de saúde, mas muitas vezes não conseguem. Nós conseguimos muitas internaçōes através do Ministério Público. Essa atuação do MP é toda extrajudicial, não tem processo, não tem contato com o juiz, nada.Aqui, nós pegamos o telefone e ligamos para o hospital a fim de conseguir a internação [...], porque a defensoria pública também está estrangulada de pedidos. Tenho apelado até para a iniciativa privada.

O Promotor é o "fiscal da lei". Sua função, neste caso, é o de zelar pelo respeito aos princípios que regem o Sistema Único de Saúde, principalmente no que diz respeito a ações coletivas. Mas, diante dos pedidos constantes, estabeleceu um canal de "escuta" direto com os cidadãos, buscando resolver impasses entre a população e os gestores do setor, encurtando, assim, o caminho dos processos judiciais: os pedidos feitos por nós, normalmente são concedidos, mas, a rigor a nossa atuação seria mais a nivel coletivo, por exemplo: eu tenho um inquérito aberto na 
questão de falta de medicamentos. Essa é outra ação civil pública que eu vou entrar para obrigar o município a manter os medicamentos básicos, pelo menos aqueles essenciais à disposição. Já foi feito um acordo, mas ele não cumpriu, então foi aberto esse inquérito. Outro exemplo é o Fundo Municipal de Saúde, já estou com tudo pronto para entrar com ação...

Se o impasse permanece e o "usuário" não obtém o acesso aos serviços de que necessita, ele recorre à Defensoria Pública que o defende judicialmente, conforme afirma a defensora pública Elis Regina:

A pessoa nos procura, aqui todos os dias atendemos vários casos. Mediante os documentos comprobatórios da necessidade e urgência dos casos é que propomos a ação e encaminhamos para julgamento. A procura por esse órgão também tem aumentado significativamente no último ano. Acredito que, por um lado, as pessoas estão tomando maior conhecimento dos seus direitos, $e$, diante da necessidade, se informam e acabam descobrindo a defensoria que vem se estruturando para esse atendimento; por outro, a imensa dificuldade de acesso a esses recursos pelos órgãos competentes [...] As dificuldades econômicas são severas, faltam empregos, quase não temos industria, a renda é basicamente do comércio, então as pessoas não têm possibilidade de adquirir, por exemplo, um medicamento. Às vezes não têm nem para comprar alimentação; então tem de haver mecanismos de defesa, particularmente das questões que dizem respeito à vida, como a saúde, além de outras [...] e nós, os defensores, somos instrumentos para viabilizar esse processo.

Não tenho lembrança de casos que tenham chegado até aqui que não fossem urgentes, porque só quando eles não agüentam mais é que nos procuram. No caso de medicamento, normalmente as pessoas já esgotaram todas as demais possibilidades de obtê-lo [...] Nós nos baseamos nas informações contidas na receita médica e no histórico que ele nos traz. De posse dessas informações e entendendo que a falta do medicamento ou de qualquer outro procedimento poderá acarretar conseqüências para a pessoa, fazemos a ação e encaminhamos para o juiz.

As longas justificativas dos processos judiciais encaminhados para julgamento por esses órgãos incorporam, na sua essência, a questão do "cumpra-se a lei" e da saúde como direto fundamental. Destacamos alguns desses fragmentos de um processo judicial que me foi fornecido por um dos protagonistas: "a necessidade dos medicamentos postulados, devido à gravidade do caso que acomete o Requerente, autoriza tutela antecipada, [...] uma vez que se for privada do acesso a utilização do mesmo, ocorre risco de vida. Outrossim, o não atendimento imediato importa em 
descumprimento do direito fundamental à dignidade humana" (Rio Grande do Sul, 2003, p.5). Continua: "a atuação do Estado [...], jamais pode fugir de atendimento de obrigação mínima que é preservar a vida das pessoas. Tenha-se sempre em boa lembrança, que o Direito não existe para o Estado, mas para o Homem, que não deve ser sacrificado [...], pois apenas nisso, simplesmente nisso, consiste a humanidade" (2003, p.18).

Tal situação é reforçada em matéria de jornal por uma juíza que afirma que "já foram realizadas reuniões com os responsáveis pela saúde, mas que a situação não se resolve a contento. As ações têm aumentado [...] envolvendo o judiciário em mais uma prestação jurisdicional. Enquanto isso, outros processos deixam de ser atendidos porque a vida das pessoas é considerada especial [...]". Na mesma reportagem, a juiza chega a afirmar que: "o judiciário está gerenciando a saúde" no município (DIÁRIO DA MANHÃ, 8 e 9/11/2003, 13).

Embora a escuta institucional e os procedimentos dai decorrentes abram perspectivas de ampliação de direitos essenciais dentro do circuito da saúde, há o reconhecimento por parte dos seus atores de que as questões são bem mais complexas e que as suas intervenções, apesar de imprescindiveis no momento que se apresentam, não conseguem uma abordagem mais sistêmica dos problemas que perpassam a saúde, principalmente por esbarrarem no modelo de atenção à saúde que é um obstáculo do ponto de vista da compreensão desse sofrimento, da organização das ações e serviços, da formação profissional e que, portanto, não contempla ações criativas, integrais e, sobretudo, com a profundidade e abrangência necessárias aos problemas que se apresentam:

Às vezes eu percebo que estamos abordando só as conseqüências e não as causas dos problemas. Acho que deveriamos ter profissionais (a exemplo de outros lugares), ou locais mais adequados que possam colaborar para uma abordagem mais aprofundada do problema, mas aqui sinto falta disso. Às vezes temos que chamar a familia para darmos um melhor encaminhamento para determinadas situaçōes.

Teve uma situação de um rapaz dependente químico cuja mãe esteve aqui para intemá-lo, pois não suportava mais a gravidade do caso. Tinha ocorrência policial, laudo para internação, solicitei a internação compulsória por duas vezes. No entanto, quando a 
mãe nos procurou pela segunda vez, foi alertada de que se houvesse necessidade de uma terceira internação, a mesma seria precedida de uma "reunião" ou conversa com todos os familiares envolvidos e, se possivel, com participação do juiz porque nós não estamos resolvendo as causas. Se eles não se estruturarem diferente na familia, não vai resolver nada e ainda assim é difícil. Eu sei que essas intemaçōes são para desintoxicar, mas que o problema principal é fora, então eu sinto falta disso. Passo Fundo está bem equipado em termos de hospitais, clinicas, mas acho que falta uma politica preventiva no municipio que além de detectar e acompanhar esses casos, possa desenvolver um programa mais amplo envolvendo as necessidades básicas que acabam por interferir nas condições de saúde (Elis Regina- defensora pública).

Infelizmente o sistema não funciona adequadamente e a gente tem que usar esse tipo de instrumento. O maior parceiro que eu tenho a nivel regional para internação é o hospital da Cidade e a direção do hospital Bezerra. Esse é um canal de resolução, mas acho que se nós tivéssemos uma estrutura na área de prevenção, um trabalho com a familia que, às vezes, não sabe como tratar com esses pacientes, outras vezes, não tem uma estruturação para isso, melhorariamos em muito essa situação. Lamentavelmente não temos uma saúde pública funcionando adequadamente como "manda o figurino", com médicos, enfermeiros concursados, não cooperados (Edgar - Promotor público).

É possivel perceber pelos depoimentos dos atores institucionais, os limites do exercício desse direito, uma vez que as possibilidades de oferta de atenção à saúde - especialmente da saúde mental - esbarram no "modelo" apresentado no circuito que, apesar dos esforços de alguns, pouco avança nos termos expressos nas leis da reforma psiquiátrica. Mas, e ao mesmo tempo, a efetivação das políticas públicas pelo Estado (não importando em qual instância) sob uma concepção de proteção aos direitos e do re direcionamento do modelo assistencial tem ficado para segundo plano. Entendo que o acesso à órgãos de "proteção e fiscalização", a exemplo da promotoria e defensoria são fundamentais, sobretudo se, para além do trabalho com as "vitimas", houver uma convergência na concretização de politicas públicas que exijam um desafio estrutural maior. Caso contrário, continuar-se-á abordando "só as conseqüências", fruto de uma cultura singular.

O faz-se justiça está presente nos "movimentos" de João-de-Barro e nas práticas dos atores institucionais. Do ponto de vista do nosso 
protagonista essa estratégia de ter sua voz "ouvida e falada" pela justiça, influencia sobremaneira sua vida diária no que diz respeito ao reconhecimento do direito, mas, sobretudo, no que diz respeito à credibilidade recebida nestes espaços; o que, seguramente, projeta ganhos maiores à esfera da subjetividade, com a possibilidade real de ganhar em dignidade, em auto-estima, em prestígio social. São experiências que contribuem para caminhos plurais, reconceituando as condições de cidadãodoente, do seu lugar social e gerando porosidades no funcionamento cotidiano que se estendem a outras dimensões da sua existência.

Ainda que essa temática mereça maiores aprofundamentos, que fogem às possibilidades dessa tese, há de se ressaltar que os nossos protagonistas, a exemplo de João-de-Barro, movimentam-se e procuram se desenvolver, buscando certas âncoras fundamentais que podem ser acionadas em momentos estratégicos e que são favorecedoras de uma metamorfose nas suas relações.

\subsection{Na mídia, outros pactos..., a lembrança de que uma determinada prática precisa "sobreviver"}

$\mathrm{Se}$ alguns pactos estão centrados nas inter-relações famíliaprofissional-instituição e são quase imperceptíveis, outros ganham visibilidade no cenário da cidade, forjando alianças junto à comunidade local e regional. Refiro-me às buscas pela "sobrevivência" de uma prática psiquiátrica traduzida nas freqüentes manchetes trazidas pela mídia, relativas às longas listas de espera para internação psiquiátrica, à manutenção e à ampliação do hospital, incutindo, sutilmente no imaginário social a concepção da impossibilidade de convivência com o "doente mental".

As reportagens nos remetem a um jogo de forças que, sob o pretexto de uso de um aparato "cientifico" para o tratamento, oculta as questões de mercado, essas sim, as verdadeiras responsáveis pela perpetuação de determinadas práticas seculares de cuidado com a saúde mental. Trata-se de uma engrenagem que, ao sentir-se ameaçada - como 
ocorreu com algumas gestões estaduais que evidenciaram o projeto de reforma psiquiátrica -, mobiliza-se, chamando em seu favor, personagens e argumentos que mais sirvam à manutenção de seu funcionamento segundo os moldes tradicionais. Um exemplo peculiar dessa mobilização foi o que resultou na ampliação do Hospital Psiquiátrico local, após a aprovação da Lei Estadual (9.716/92), proibindo a "construção e ampliação de hospitais psiquiátricos públicos e privados e a construção e o financiamento pelo setor público de novos leitos nesses hospitais (Art. $3^{\circ}$ )."

Modificar essa estrutura - como propõe o projeto da reforma psiquiátrica - requer a construção de serviços dotados de profissionais preparados para o exercício deste tipo de atenção, assim como é necessário que o imaginário social sobre a loucura seja recriado, isto é, a sociedade precisa confiar na eficácia dos novos serviços, percebendo que é possivel conviver com esse tipo de cidadão no espaço da cidade. Este processo exige trabalho, convencimento, conhecimento do novo projeto para uma população que não é, necessariamente, insensivel a determinadas causas, mas que aprendeu a conviver com a loucura, afastando-se dela. Implementar uma mudança deste teor significa correr determinados riscos, como o já conhecido "movimento" de profissionais/instituições, principalmente os oriundos do campo hospitalar que aparentemente manifestam-se favoráveis à reforma, mas, na prática, fazem um discurso apelativo, indicando obstáculos à mudança, tais como: a falta de recursos financeiros, a dificuldade de ampliação do número de leitos, o perigo que o sofredor psíquico oferece às ruas, a desqualificação da família para o cuidado, tudo isso para mascarar a defesa da manutenção do tradicional modelo médico-psiquiátrico centrado na hospitalização e na exclusão social. 


\section{Reportagens sobre o Ministério Público e a Defensoria Pública referentes a área da saúde}

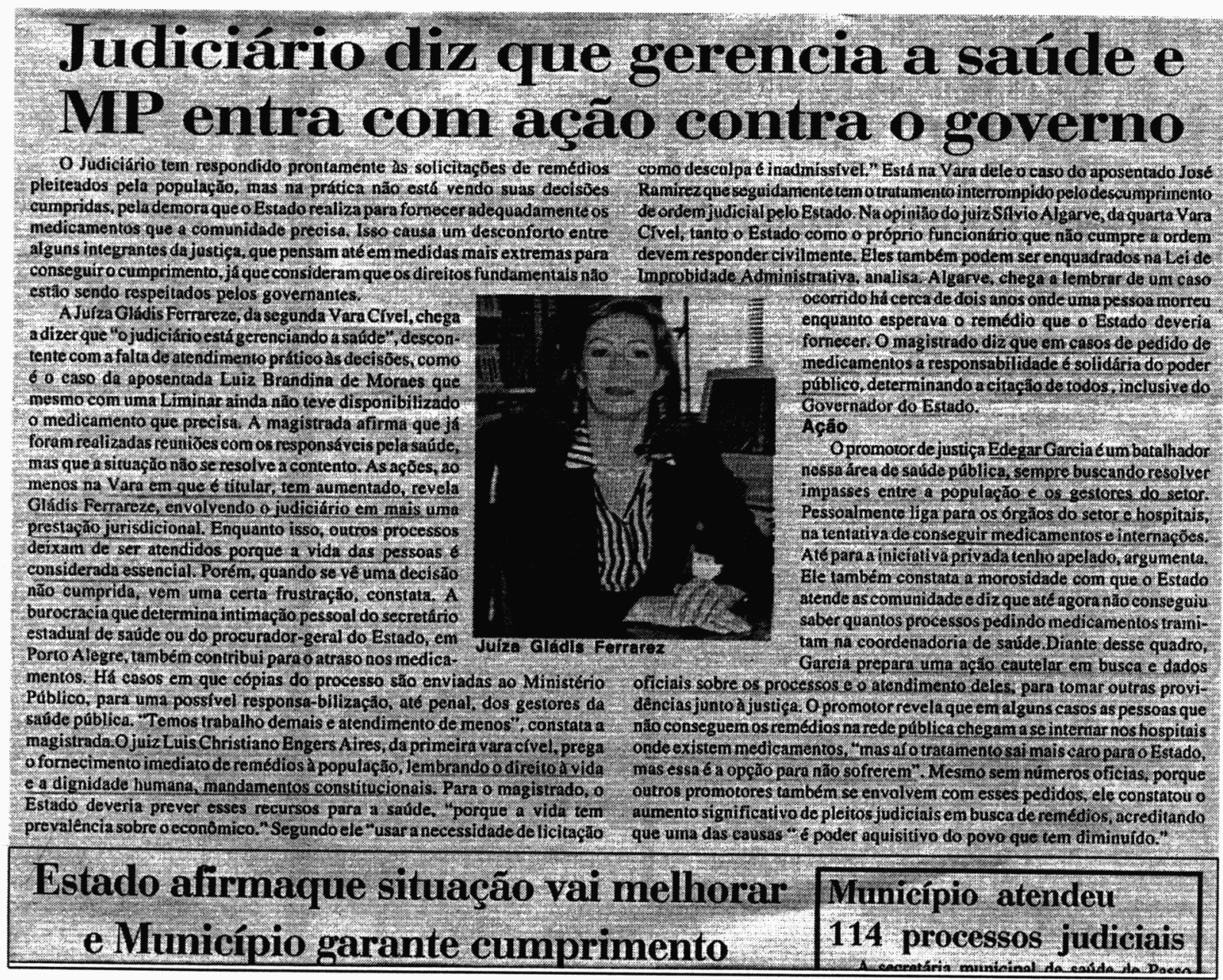

Reportagem do Jornal Diário da Manhã, Arquivo DM, Passo Fundo, 08 e 09 nov. 2003, sobre o Judiciário e a situação da saúde no município, 2003, p. 13.

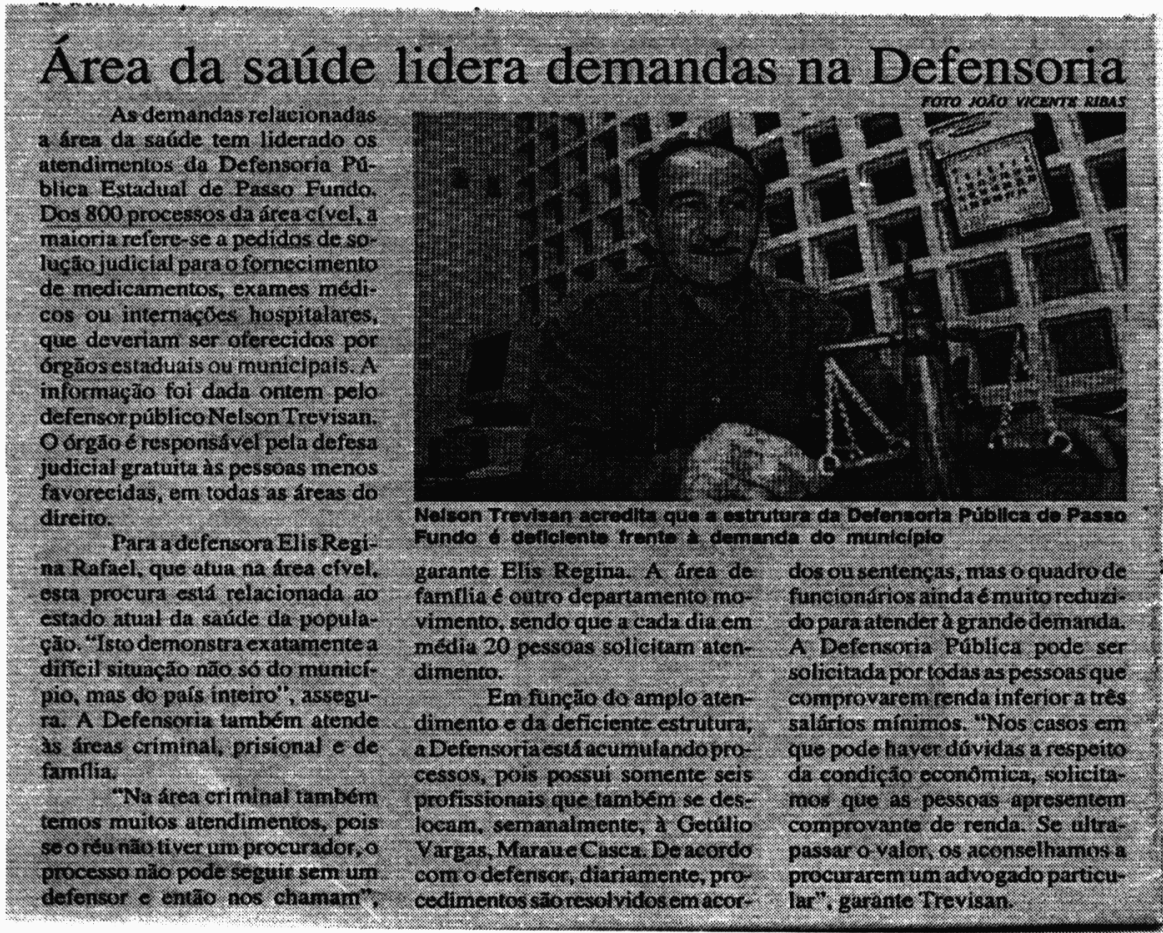

Reportagem do Jornal Diário da Manhã, Arquivo DM, Passo Fundo, 11 fev. 2003, sobre a demanda da saúde na Defensoria Pública. 2003, p. 3. 


\section{Hospital Bezerra de Menezes realiza} campanha para enfrentar dificuldades

Q uem passa pela frente do predio do Hospital Espirita Bezemr de Menezes (HEBM) nato percebe a real situaclio em que se encontra essa Instituichlo. Suas necessidader de reestruturaç7o fisica interna sio reais et falo que o Hospital precisadaajudade todos. Panseterumaidcia, nilo há quartos suficientes para atender a todos os necessitados, principalmente, as pessoushumildesquesłoamaioria. Dos 80 leitos parn internacĭlo, somente 67 estäo funcionando. E emalguns, percebe-se ainfiluncilo, em outros janelas e portas nato funcionam corretamente. 0 refeilorio 6 no meio do corredor para ceder espaço a outras atividades.

Além disso, nalo tem banheiro e nem área coberta no patio part receber os familiares e visitantes dos pacientes, quando, em dias de chuva, visitantes, parentes e pacientes precisam dividir 0 espaço interno dos corredores para converser. Nito há atividades de lazer no Hospital, a única sala de recreacto 6 muito pequena, onde só há uma mesa de baralhoe uma mesa de ping-pong: alavanderiae aroupariasiojuntas eladeadas denfermaria-cadasetor. deve ter sen próprio espaç; : cozinha nio tem safta externa, há somente uma portainterna queliga diretamente com a ala de leitos particulares; enfim, hívíriosouttos problemas estruturis queprecisan ser consertados. "Tudo isso, cria dificuldades para realizar um traballho adequado. Chegamos aum ponto de exaustilo, onde na parte da frente do Hospital, naso havia esse portio. Ele foi doado por familiaresdeumpaciente",comenta

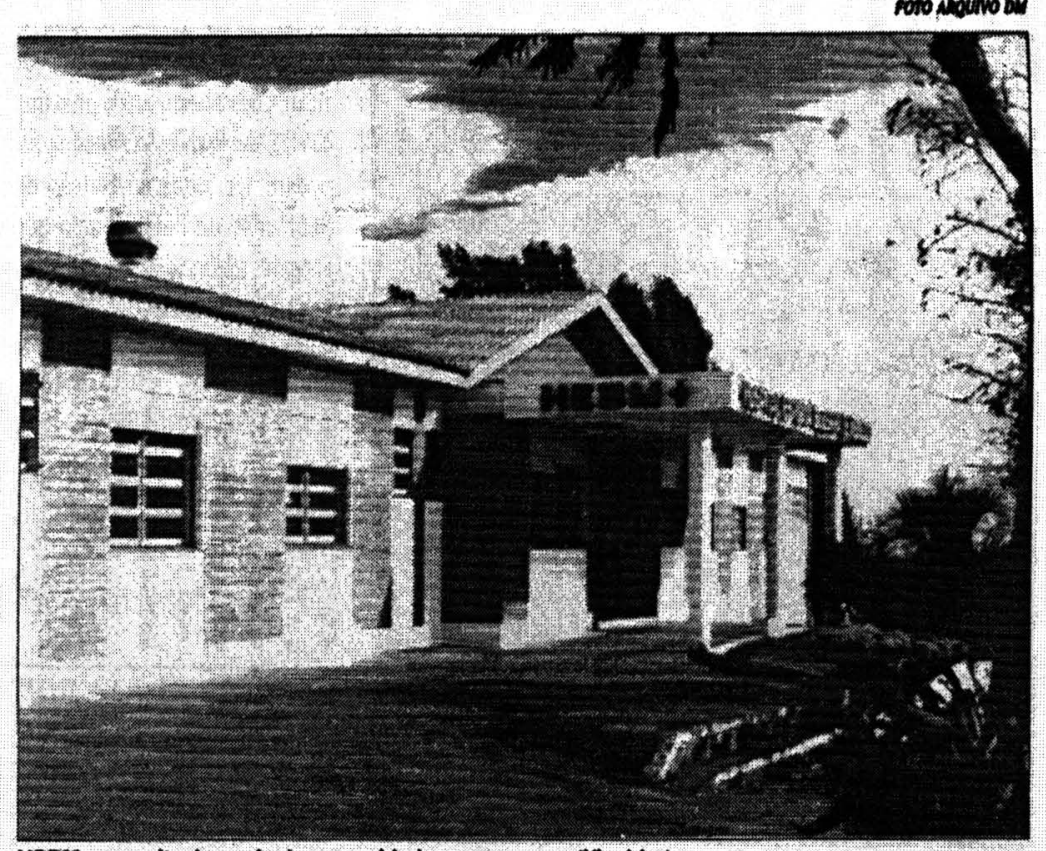

HPGU neceselta do apolo da conunidade para superar diflculdades

odr. AlbinoJulioSciesleski, diretor deixamos de atender um paciente de atendimento.

doHEBM."Todosesses problemas por falta de leitos", disse o diretor Agelo imediata e inicial foram vistoriados e constatados dr. Albina. NoEstadodoRioGrande pelo GAP (Grupo de Avaliaglo do Sul, há somente tres locais que Psiquiátrico) que exigiv uma fazem atendimento psiquiátrico. atualizaçlo : adequaçlo nas SantaMaria Pelotase Pono Aleze, estruturas do hospital para poder caso o HEBM venha a ser continua mantendo o atendimento desativado, muitas pessoas e o convenio com o SUS.

Objetos básicos como. cadeiras, sofis, mesas, tambem estio em falla. "Nós, recebemos rocentenentealguns bances parso patio e para a saleta de recepglio porque nem isso nós possufamos", reveladr. Albino.

0 HEBM abarca cerca de 200 municipios, sendo que atende. en métia, 40 pessoas por semana. A média de internactio de un pacientéde 22 dias. 'Muitas vezes, ressaltou que ja existe uma equipe os problemas porque vém pessando o Hosgital Psiquiátrico Bezerra de Menezes, que precisa da colaboraçlo da comunidade regional a fim de continuar com o trabalho que vem prestando durante anos a toda a regilio do Planalto.

Paneencontraruma posstivel soluclio para os problemas, foi escolhida uma comissio sofretio.

organizadora de uma Compan Comunitária Regional Pr Modenizactloe Ampliaçiodac: desabde, que realizard a rifade 1 automóvel Palio, ano 99, ap pm RS10,00 onimero, comsonteiop Loteria Federal no dia 19 dezembro do corrente ano. campanha, será oficialme: divilgada nos próximos dias.

A comissåo ficou ass constitudarpresidente:AlbinoJ! Sciesleski; vice-presidenti Daltro Jose Wesp, Augu: Baier, Eronilde Ribeiro e la Heckler comisslo. Lécai engerheiros Nino Robe Machado, Maria Aldina Po Nobre e Jorge Rossato; comis! do Divulgaglio o Marketii publicitário Paulo C. Rigi comissťo de Expansăo Arrecadaçäo: Carlos Antôr Madalosso, Antonio A. Pretto, Jh Idilio Saggin, Paulo Canary Rosemar Stefenon, Eloisa Tin Teixcin, Valdelinioe DionéiaCan - Heloisa Goelzer de Almei tesoureiro:Lucineu Bohrer. Estacomissilo, desdejáte dependencias do Hemopasso de PassoFundo, foirealizadanaúltima quarta-feira, dia 22, importante reunilo, I qual compareceram inúmeras autoridadeseconvidados especiais.

Naocasilio, foram debatidos multidisciplinar pan cuidar dos pacientes adequadamente $\mathrm{e} \mathrm{há} \mathrm{um}$ projelo planejado para a reforma. Para construçajo de 400 metros de íreanecesediria, calcularamum valor

de, aproximadamente; RS $306.000,00$. Eles pretendem instalar um ambulatório e un hospital dia, que servirá para atender pacientes empenhada num trabalho recuperaçẫo do nosocom empreendendo essa campanha arrecadaclo de fundos para le em frente as obras que se far prementes para o hospital, tend coordenacio dos Rotary Club Passo Fundo, Rotary Club Passo Fundo-Norte e Rotary C Integridade, integrantes do Dist 4700 . Assim, loda a comunid regional estí sendo convocadai engajar aesta campanha, que I emprol de todos os que necessit dos servicos que salo presta pelo Hospital Psiquiatrico Bezz de Menezes.

Reportagem do Jornal Diário da Manhã, de 06 de agosto de 1998, sobre o Hospital Bezerra de Menezes. Arquivo DM de Passo Fundo, 1998. p. 9. 


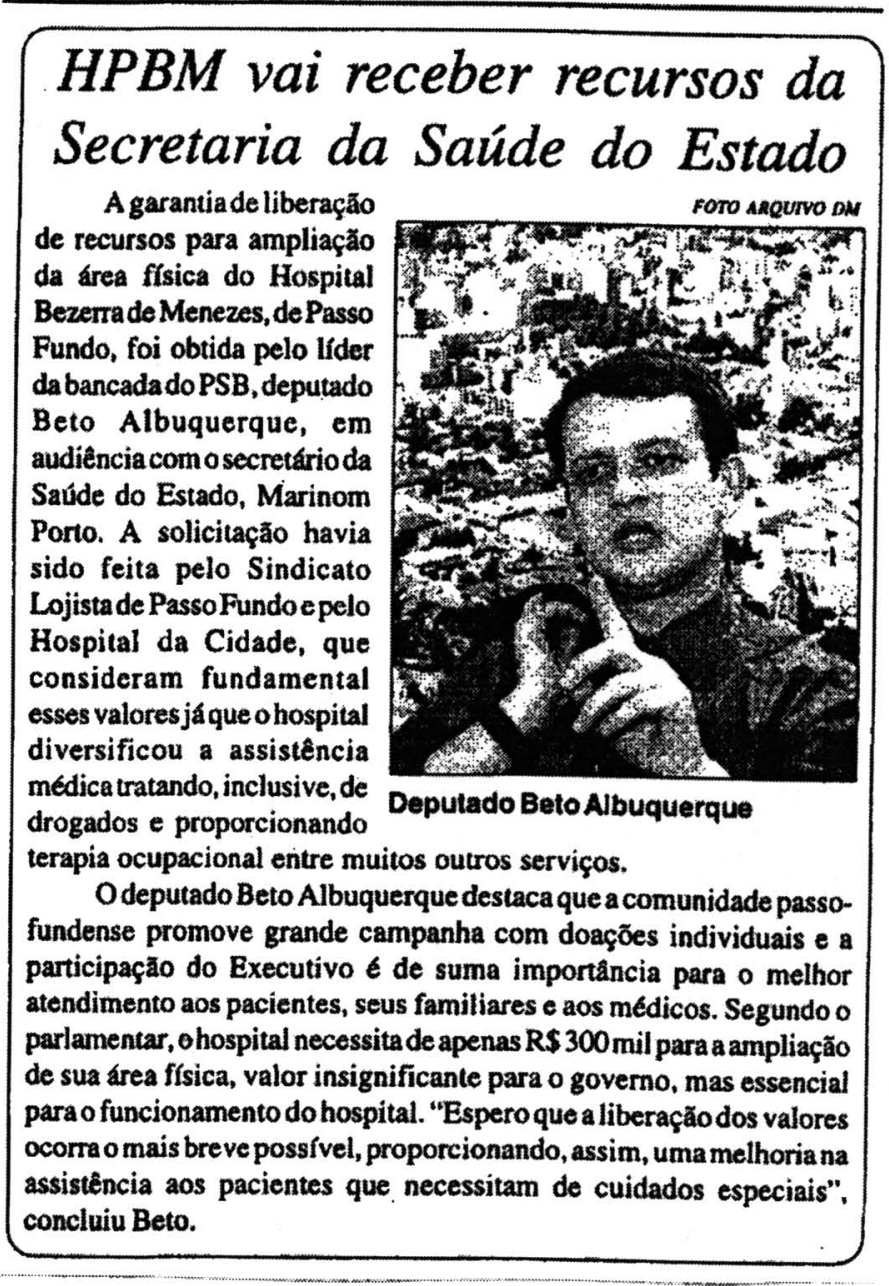

Reportagem do Jornal Diário da Manhã, Arquivo DM, Passo Fundo, 23 set. 1998, sobre o repasse de recursos da Secretaria da Saúde do Estado para ampliação do Hospital Psiquiátrico, 1998, p. 5.
GERAL

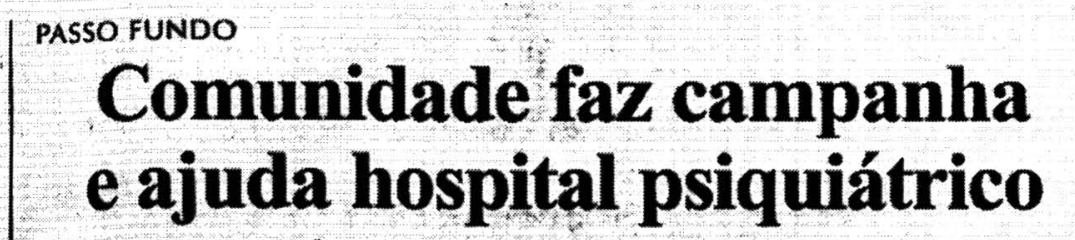

Instituicão tem 69 leitos e a maioria dos atendimentos é feita pelo SUS ADREANE BECKRR -

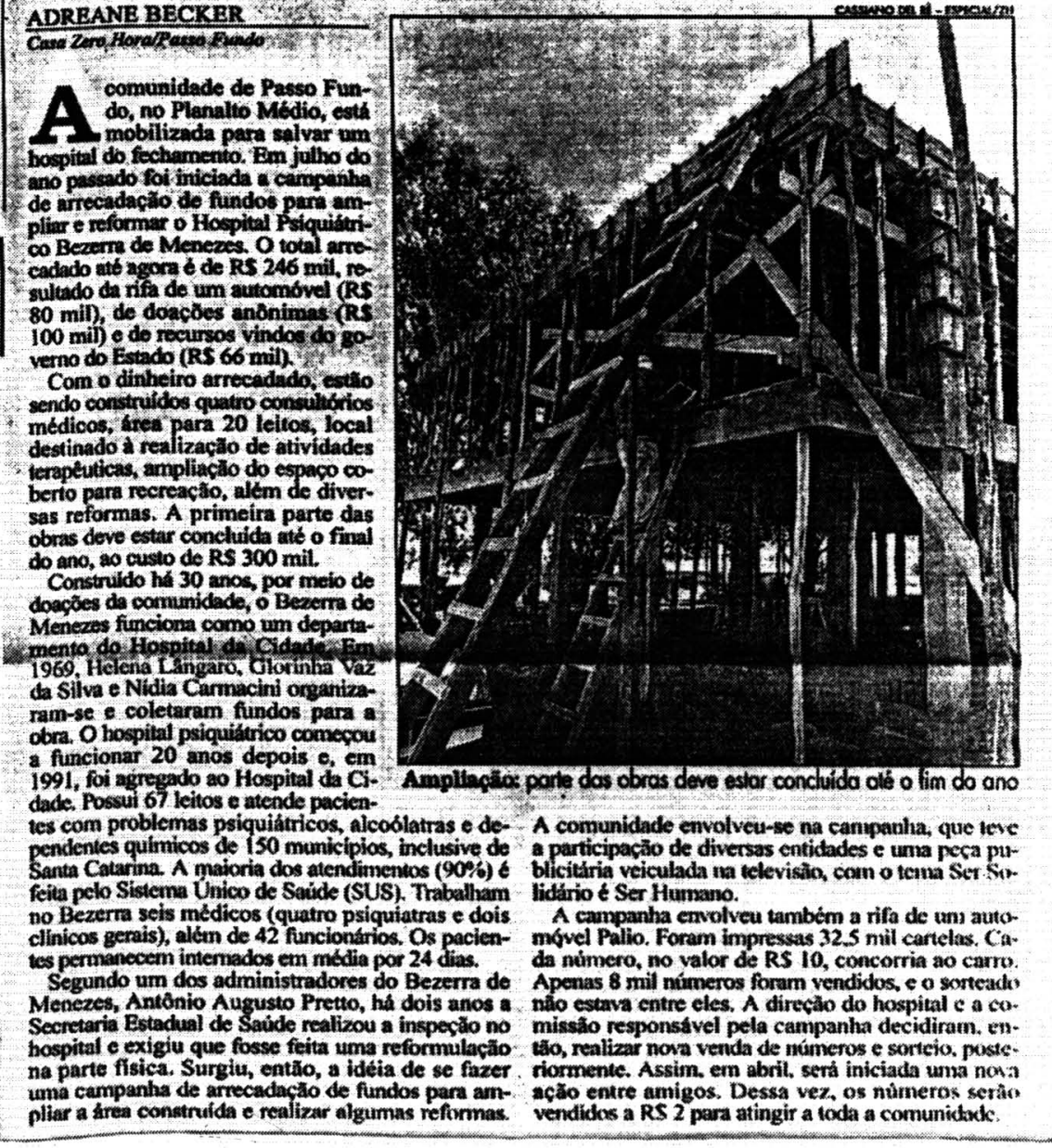

Reportagem do Jornal Diário da Manhã, Arquivo DM, Passo Fundo, 06 ago. 1998 cnhre camnanha da comınidade nara n Hesnital Psinı ıátricn 1998 n 0 


\title{
Doações mudam a situação do Hospital Bezerra de Menezes
}

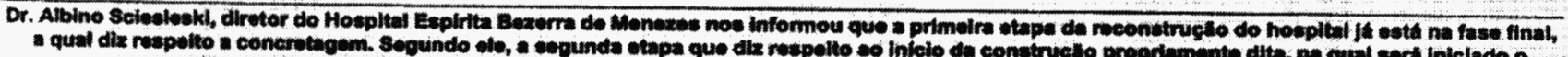

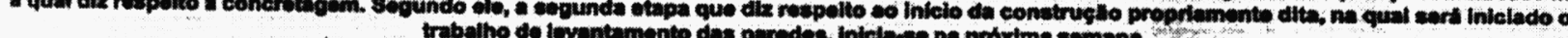

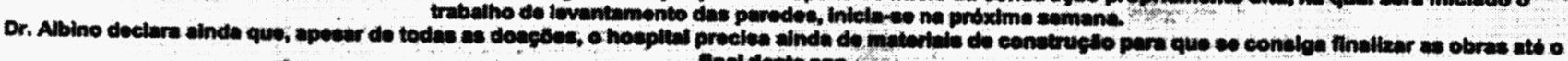
final deate ano.

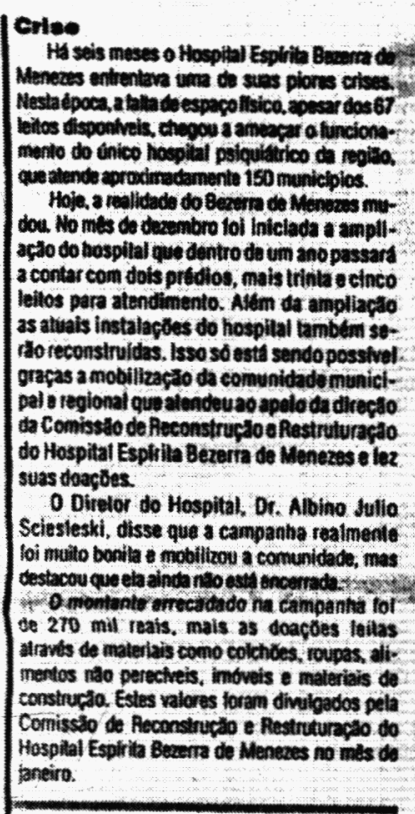

rive

Meneres meses o Hospial Espiria Becernat de

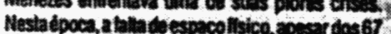
leitos dispontiveis, thepou a amecyr af uncione. mento do énico hespital psiquiatrico de regite. ve atente aproximadamente 150 municlpios.

Hoje, a realidado do Bezerra de Manozas muaclo do hospilal quo dentro da um ano passar contar com dois predios, mais trinta ecinco S at para atendimento. Aiem da ampliapto

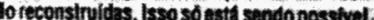
gracas a mobilizacto da comunidade municlal e regionat ousatendeuso apalo da directo a Comissto de Reconstruclo e Rastruturapto suas doacties.

O Direlor do Hespital, Or. Albino Julio Ciste que a campanba reaiment ci musto bonila e mobilizou a comunidade, mas destacou que ela ainda niso est tncomada. de 270 mil reais, mais as doacoes feilas aravis de materiais como colchoes, roupas, alie mentes najo pereckiteis, imbueis e moteriais to Construcia Estes valeres foram diviloados pela Hospital Espirit Berern de Meneres no mits de

\section{Campanh}

Avaliando a participacto to co. criou expectativa, diz ello. E nos munidade na Campanhe de ajuda ao Hospital Espirita Bezerra de Menezes. O Dr. Afbino destaca o apoio dos velculos de comunica. flo de Passo fundo e disse que "no intecio o retomo de comunidade toi muilo pequeno. mas com o decorre do tempo, ela comecou a demonstrar sea alto espirito de solidariedade. Nos tivemos algumas ooscoes importantes. particutares. pessoas nsicas, que ajudaram : estimular a campanta Tambem to. vernos muilas deacues de pessons urfticas e de associacies como Lions, Rotary, colégios, escolas. CTGs o algumas entidades religiosas que colaboraram mui10. realizando promociles como: jantares, galetos e churrascos. Nos tivemos ate alguns munictpios proximos, de regilo que ajudaram bastante. realizando pedagios. Com isso tomos juntando o dinheire entusiasmo" De pois, salients or. Albino, surgiu campanthe to Pallio. Talves esea tentra sido a campanha que mais 30

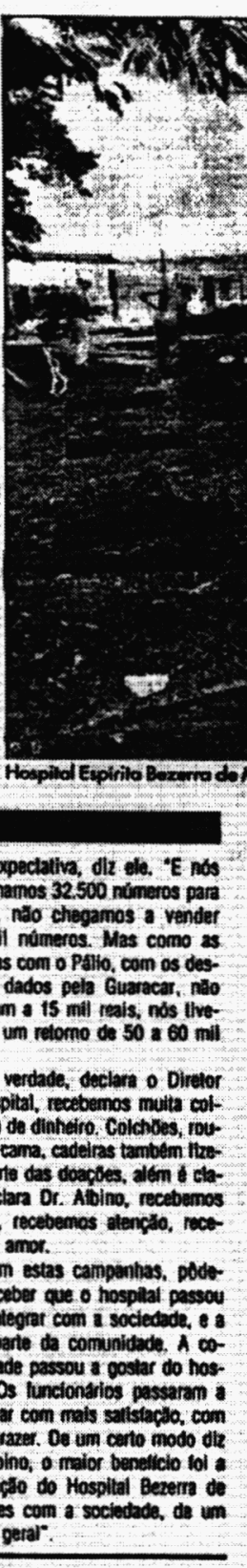

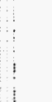




\section{Faltam leitos no Hospital Psiquiátrico}

O Hospital Psiquiátrico Bezerra de Menezes, se en contra com os 81 leitos oferecidos totalmente preenchidos. Com a falta de vagas, o número de pacientes, que aguardam o atendimento pelo Sistema Único de Saúde(SUS), aumentaa cada dia. Mesmo depois de passar por uma ampliaçăo. Hospital ainda possui uma quantidade insuficiente de leitos para atender a dernanda dos pacientes de toda a regiăo.

O Hospital foi ampliado e renovado em 2000 , graças ao auxflio de toda a comunidade passo-fundense $e$ da regiáo. A partir da reforma, 0 Hospital passou a oferecer ao seus pacientes uma methor qualidade no atendimento e uma alta infra-estrutura nos tratamentos psiquiátricos. Deacordocomo Diretor Clínico Hospital Psi quiátrico Bezerra de Menezes, Dr. Albino Júlio Scies. leski, a demanda de pacientes dobra a cada dia. Desta forma, o Hospital náopossui estrutura para atender todos os pacientes que procu. ram atendimenlo psiquiá. trico. Hoje, mais de 30 pessoas permanecem na fila aguardandourna vaga parao atendimento psiquiátrico especializado.

“Em primeiro lugar são atendidas as pessoas que se encontram em estado mais grave, mas jamais édeixado de atender ou de encaminhar as pessoas que entram em contato ou procuram o atendimento do Hospital As pessoas que se encontram em quadros extremamente agudos, săo intemadas no Hospital da Cidade, e depois sáo transferidas para o Hos. pital Bezerra. Outras pessoas, săo encaminhadas ao Posto de Saúde ou aos órgáos responsavel por doencas", relata Sciesleski.

Afim de diminuir o problema da falta de vagas, o Hospital fez um convênio com a Secretária de Saúde. Através deste convênio, to-

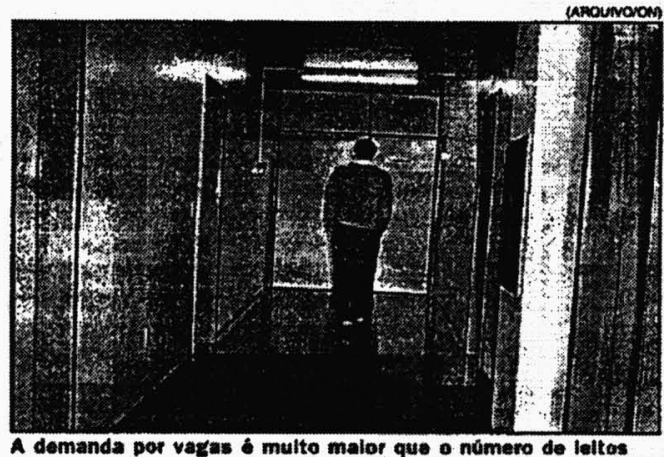

A demanda por vagas o multo malor que o numero de laltos

dos os pacientes vindos das cìdades da regiáo, possuem um relatório que é enviado para os médicos locais, onde os pacientes podem continuar o tratamento na pró pria cidade.

"A repercussăo dos nos. sos pacientes, se deve náo apenas a ajuda médica, mas também as atividades mul. tidisciplinar da propria sociedade. E muito importante que nos possamos transfor. mar as cidades mais próxi- mas em atendimentoextensivo do Hospital Psiquiátrico", declara o diretor do Hospital.

O Hospital proporciona 0 atendimento para pesso. as da cidade e da regiăo, atraves de trabalhos e atividades terapeuricas modernas, com um quadro cínico muito disciplinado e quali. flcado, alem de oferecer todos os medicamentos modernos que existem no mundo.

\section{Cerca de 100 pessoas por mês aguardam internação no Hospital Bezerra de Menezes}

Mais de 70 pacientes estão sendo atendidos no momento

A proximadamenteuma centena A de pessoas aguardam inter. nação todo o mês no Hospital Be. zerra de Menezes de Passo Fundo. Săo advindas de todas as cidades da regiăo, inclusive da parte oeste do estado de Santa Catarina.

Segundo a enfermeira do hospital, Celita Arezi, esse fato acontece devido aos poucos hospitais especializados que atendem esses casos, além do que os hospitais gerais ainda nato recebem esses pacientes, que necessitam uma estrutura e os cuidados de uma equipe especializada. "Aqui esta um dos motivos da grande lista de espera: ou os pacientes sảo encaminhados para o Bezerra ou para Ana Rech", argumenta ela,

O hospital Bezerra de Menezes atende peloSUS 16 leitos femininos, 35 masculinos e mais 30 leitos estaxo preenchidos por pacientes que têm convênios ou particulares. "São 71 leitos totalmente ocupados. Muitos ainda ficam aguardando na lista de espera, mas näo temos condiçōes de atender bem se a demanda for maior do que assim", destaca Celita.

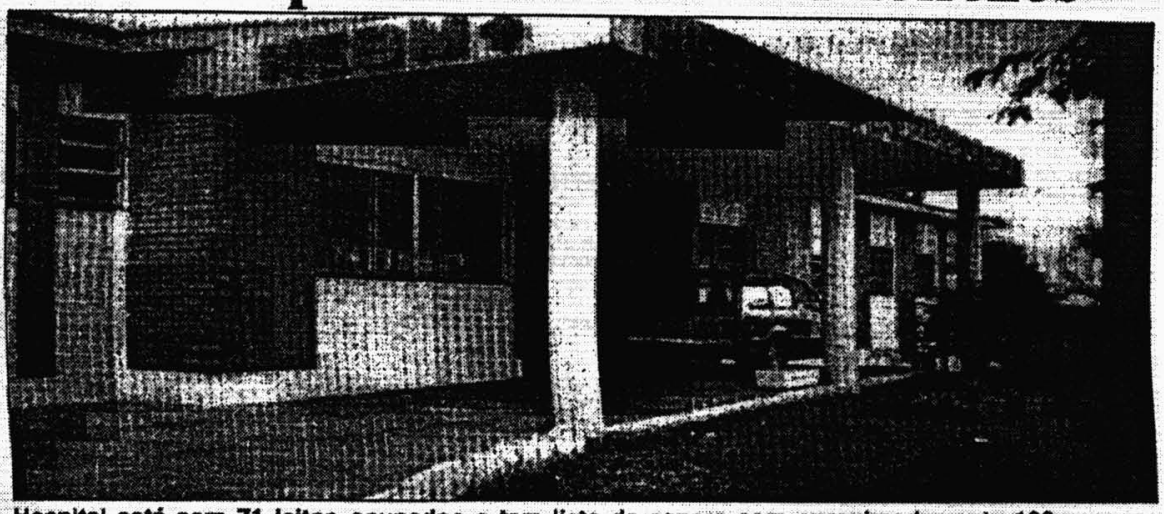

Hospital está com 71 leitos ocupados tem lista de espera com aproximadamente 100 pessoas cadastradas por mes

seja, a maioria delesinterna eficaem tras fixos e mais alguns que atentorno de 30 dias. Entăo $t$ um mes dem esporadicamente. Todos os para abrir nova vaga. Muitas vezes pacientes, no momento da entrada também, o paciente dáalta, mas nåo sâo consultados ainda por clínicos recebe os cuidados e a assistência gerais, que no hospital são em núque deveria ter. Desta forma, acaba mero de dois.

voltando para nova internação e a fila de espera continua grande.

Segundo administrador hospital recebe desde Dohrer, internaçöes psiquiátricas im pouco mais calmos, sempre vāoocorrer. "O importante até os extremainente agitados (em que se tenham recursos humanos surto). Para fomecer os cuidados e materiais necessários ao atendinecessários a recuperaça, conta mento e principalmente a recuperacom uma equipe composta do uma câo", ressalta ele.

psicóloga, três enfermeiras, uma nutricionista, uma farmaceutica, um tente social, seis médicos psiquia- lia na recuperação do paciente. "Se receber um bom atendimento no hospital e quando voltar para sua cidade năo tiver o acompanhamento necessário, voltará a serinterna. do", ressalta.

Celita afirma aindaqueeventos como o Fórum sobre Saúde Mental, realizadonaultimaquartafeira 24, sãomuitoimportantes, pois proporcionamuma troca deidstiase os hospitais a $6^{\circ}$ Coordenadoria Regional de Sauder "E uma cooperacãa na busca de solucoóes práticas para aperfeiçoar a qualidade do atendimento para aqueles que ne. cessitam", finaliza. experiências entre os municípios, 


\section{ENTRELAÇANDO NOVAMENTE A TRAMA}

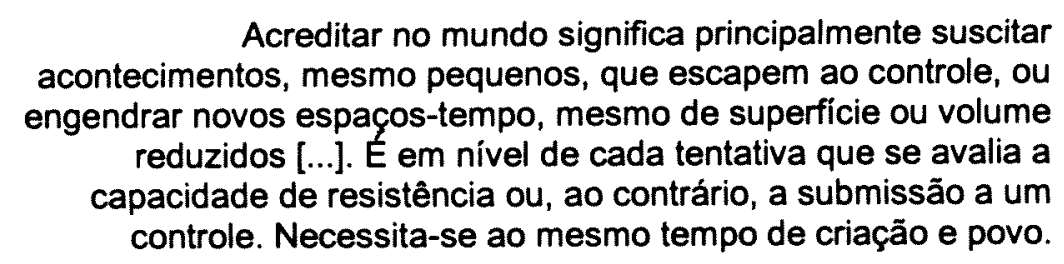

(Gilles Deleuze, 1992, 218)

Foi acreditando que era possivel descobrir algo novo nas histórias das pessoas que adoecem mentalmente de forma grave que cheguei até aqui. Ao ingressar no doutorado minha intenção era a de desenvolver uma pesquisa que pudesse dialogar mais com as instituições de saúde mental, particularmente, com as "novas instituições" que surgiram com a Reforma Psiquiátrica. Queria também apresentar uma história dos serviços públicos que falasse de liberdade, de autonomia, de sujeitos incluidos nos diferentes espaços da cidade, onde houvesse possibilidades terapêuticas compativeis com as suas necessidades, enfim, onde as pessoas fossem apresentadas como cidadãs na sua diferença. Mas, como os caminhos não são lineares e Passo Fundo, como a maioria das cidades brasileiras, não fez nenhuma "revolução" nas políticas institucionais de saúde mental, fomos vendo o problema de outros ângulos e descobrindo outras nuances que, de alguma forma, poderiam ajudar a refletir essa problemática no local.

De inicio não tinha idéia de quem seriam os interlocutores, nem de que situações de vida eu encontraria, que fossem favoráveis, à defesa da tese de que o mundo cotidiano teria algo fundamental a nos ensinar sobre o sujeito que também vive, na sua existência, o sofrimento psíquico.

Caminhei inicialmente, pelas ruas de um bairro, pouco à vontade e desconfiada de que meu investimento não traria grandes contribuições. Afinal, já existe uma considerável produção de trabalhos sobre essa condição humana. Sem pressa fui me deixando envolver pelas histórias que aconteciam nos espaços da cidade e fui percebendo que aí a vida tinha 
outros encantamentos e sentidos. É verdade que foi preciso "treinar" o olhar para fugir do "vício" que faz saltar aos olhos de uma enfermeira com formação em saúde mental, as "síndromes", para poder ver a vida mais como ela é, no seu cotidiano. Outras histórias, ainda pouco visiveis para mim foram ganhando evidência. De um lado, o contexto da cidade sai de um pano de fundo homogêneo para um poderoso recurso articulado ao mundo subjetivo e expresso em ricos itinerários urbanos; do outro, as instituições de saúde se constituem em "tortuosas" tramas ao serem apreendidas nas micro-relações cotidianas de quem vive, sofre e precisa lançar mão desse recurso em diferentes momentos da vida.

O encontro e a escolha de uma proposta metodológica que me levou a seguir um percurso a partir do local de moradia foi de fundamental importância para essa investigação pois, através dessa via, pude compreender a história e a dinâmica locais e estabelecer uma interação com os moradores, para assim reconhecer os sujeitos sofredores mentais do bairro. A partir dai foi possível explicitar aspectos de suas trajetórias, compreendendo alguns fluxos que emergiam nos encontros intersubjetivos, trazendo elementos essenciais para a construção dessas considerações provisórias.

O bairro Vera Cruz, local que recebe gente todos os dias, ainda preserva características peculiares da vida rural, onde os laços familiares e de vizinhança são importantes na conformação das redes sociais e afetivas que servem de sustentação e referência à continuidade de suas vidas nesse lugar. Os moradores considerados "doentes mentais" que comigo construiram esse trabalho vivem no bairro desde há muitos anos e, por isso, reconhecem e são reconhecidos naquele meio social. Mesmo quando estão fora-de-si, as familias e a vizinhança, os relacionam com seus processos históricos, sociais e culturais, favorecendo, em alguma medida, a manutenção de vínculos e de papéis anteriormente exercidos.

Ao me aproximar das relações sociais e interpessoais vividas por esses sujeitos constatei que suas interações e seus comportamentos sociais 
estavam diretamente relacionados aos espaços freqüentados por eles, tornando suas dinâmicas muito distintas, fazendo-me perceber duas grandes cartografias: a cartografia das instituições de saúde e a do bairro.

No âmbito institucional, sobretudo hospitalar, as limitações tomavam uma dimensão grandiosa, a gravidade parecia se acentuar. Era o lugar do "fantasma da doença", da pouca personalização, das incapacidades. No bairro, compreendido pelo espaço doméstico e pela rua - embora nessa, os ganhos se tornavam mais visíveis em relação à casa -, apesar das dificuldades e limitações, os sujeitos da pesquisa mantinham contatos importantes, encontravam saídas mais flexiveis. Aí, salientava-se um sujeito que mesmo reconhecido pelas suas diferenças, preservava desejos e criava possibilidades, envolvendo-se em diferentes situações na busca da concretização de sua história. A instituição dotada de rotinas e protocolos para intervir sobre esse sofrimento humano ,vai tornando o sujeito "paciente", passivo e, muitas vezes, despojado dos seus direitos e investimentos simbólicos. A rua, embora tenha regras, permite o exercício da liberdade, da negociação, da convivência, pautando-se mais pela vida do cidadão.

São duas paisagens que oferecem recursos distintos, embora se entrecruzem e se aproximem em muitos momentos da vida dos protagonistas, sobretudo porque há uma prevalência na compreensão da "doença mental" oriunda da psiquiatria - discurso competente - que é dominante no circuito da atenção à saúde mental e que se dissemina pelas familias e pela população do bairro.

As delimitações do bairro compõem uma modulação do espaço público em que são desfrutadas as relações mais intensas desses sujeitos, análoga ao que Magnani denominou pedaço. Há uma lógica de uso que torna alguns locais diferentes de outros, ou seja, não se trata de qualquer espaço público. Trata-se de um espaço nas proximidades de suas residências e, por vezes, nas proximidades de serviços de saúde, onde essas pessoas encontram diferentes formas de apropriação construindo 
pontos de apoio, quer seja para o desenvolvimento da sociabilidade, do trabalho, de negociações, do exercício dos direitos, quer seja para dar vazão àquilo que ficou fragilizado ou cristalizado com a vinda do sofrimento mental e que não encontra saida tão satisfatória em outros espaços. Situação semelhante foi desvendada por Magnani (2003) em uma etnografia sobre os surdos na cidade de São Paulo. O autor observou que numa visão universalizante, eles eram tratados como deficientes; enquanto que em espaços próprios e mais intensos de contato entre seus pares, eles aprimoravam seu principal elemento distintivo, a língua de sinais, e, com isso, a própria possibilidade de se desenvolver, tornando-se apenas diferentes. Esse olhar contribuiu, em nosso universo, para relativizar noções generalizadoras a respeito desse grupo, tais como a periculosidade, a incapacidade e a exclusão.

Se a história da psiquiatria foi mostrando que os loucos precisavam ser retirados da sociedade por não conseguirem seguir as regras minimas de convivência, ou ainda, porque obstaculizavam o desenvolvimento econômico, podemos fazer um contraponto com a história vivida pelos nossos protagonistas no bairro. Do ponto de vista do trato com a cidade, podemos dizer que eles não se mostram sem rumo, nem perturbam a convivência. Ao contrário, vivem fraternalmente e se apropriam da cidade de tal maneira que podem não só viver nela, como ainda estabelecer estratégias de vida, de reforço de suas referências, de escolhas, o que torna esse pedaço, um exercício vital para enfrentar outros momentos da existência. Paradoxalmente à história da psiquiatria, que construia serviços para "proteção" dessas pessoas, o que observamos é que, salvo uma ou outra situação mais delicada, os espaços públicos fornecem elementos mais consistentes de proteção, uma vez que permitem equacionar a subjetividade e o desejo no contexto das relações sociais.

Limpar um jardim, comprar mercadorias, descobrir as maneiras de interagir com as pessoas e instituições, desenvolver um trabalho, fazer amizades, descobrir os direitos, obter o remédio, sentir-se um defensor do bairro, amigo do policial, encontrar um namoro, ir à missa, dar uma bronca 
em um desafeto, brincar com uma criança, acompanhar o movimento da cidade, e tantas outras situações instauradas no espaço público, são estratégias dotadas de fundamental capital afetivo e simbólico, que alimentam esperanças, fazendo com que o desejo, ou o desamparo, possam encontrar meios de se exprimir. É, principalmente no pedaço do bairro que os protagonistas podem exercitar e construir com cada um dos fragmentos encontrados, os vínculos identitários que fazem a sua própria sustentação. São espaços, onde eles se tornam mais potentes e protegidos para estabelecer relações de troca diante da sensação de perda do senso de continuidade de suas identidades, constantemente ameaçadas.

Como exemplo emblemático da relevância desses espaços registramos a diferença dos universos de dois protagonistas: Beija-Flor e Pomba-Rola. Enquanto ele absorve-se na rua permanecendo durante todo o tempo possivel, ela vive quase exclusivamente dentro do ambiente doméstico, tornando o seu universo de trocas e possibilidades muito mais limitado, aumentando sua dependência em quase todos os aspectos da vida. Embora, possamos dizer que no caso de Pomba-Rola a "rua vai para dentro da casa" através de uma familia extensa que a visita acaba de tempos em tempos, essas relações, mediadas por "aqueles que trazem", não têm a mesma riqueza da experiência dos que dela se apropriam. Por conseguinte, as informações contidas nessas trajetórias, também expressam as interações nos diferentes universos dos sujeitos, o que justifica nessa tese a maior produção de uns sobre à de outros.

No entanto, quando esses espaços se distanciam ou se conectam com pessoas de fora, as diferenças ficam mais sensiveis e as relações podem ser vistas como ameaçadoras, excludentes e desestruturantes, silenciando suas vozes e requerendo outros comportamentos e outras estratégias. Isto pôde ser percebido, por exemplo, na relação com a escola que não aceitou o candidato a aluno, quando o identificou como "doente mental", ou no motorista do coletivo urbano que deixava no ponto de ônibus nosso sujeito de pesquisa por se tratar de uma pessoa "cambaleante". 
Outras nuances são evidenciadas quando as relações passam a ser mediadas pelas instituições de saúde mental (e por todo o aparato que se constitui em torno delas). Essas relações se "artificializam", ou melhor, se institucionalizam de modo a deixar pouco do que é propriamente do sujeito, de alguém que necessita de suportes terapêuticos "continentes" e consistentes para que a saúde se faça possivel. Ao contrário, o que percebemos é que nesses espaços, a produção subjetiva sofre uma captura, salientando-se no estabelecimento das terapêuticas aquilo pode ser regido pela norma e pelos padrões definidos a priori.

Cartografando suas trajetórias nas instituições que compõem o circuito da saúde, percebemos que, desde a primeira crise, há um endereçamento para o sistema psiquiátrico tradicional (Hospital Psiquiátrico) - o batismo à institucionalização - realizado por profissionais de saúde de diferentes serviços da cidade e, com o passar do tempo, da própria família. Cada serviço de saúde contribui à sua maneira, para que o sujeito chegue ao atendimento nas situações de extrema gravidade e tenha como destino o hospital psiquiátrico; ou seja, na medida em que restringem o acesso, em que não trabalham sua base territorial, em que desconhecem as pessoas e os problemas de saúde de sua região e não pensam projetos articulados, estão reiterando o sofrimento e a exclusão. A família, por desconhecer outras possibilidades e sem um suporte terapêutico que possa aliviar sua sobrecarga, tem dificuldade em escapar da lógica instituída, naturalizando a institucionalização como o principal caminho para situações psíquicas tão diversas. Ainda que o hospital psiquiátrico seja o único lugar a receber pessoas em situação de crise psíquica, predomina nesse campo um conjunto de forças e mecanismos impositivos altamente entrópicos para a complexidade que emerge do sujeito, dificultando muito a reestruturação de seu mundo subjetivo, pois, além de reduzir as chances de expressão com o "repertório terapêutico" disponibilizado, ainda reforça a necessidade de exclusão da pessoa que vive o sofrimento.

Para nos aproximarmos ainda mais do sentimento vivido nessas circunstâncias, retomemos o questionamento perspicaz de Beija-Flor a 
respeito de suas constantes passagens, não consentidas, pelo hospital psiquiátrico: o que achariamos se nos levassem para um lugar, nos enrolassem e não nos deixassem sair por trinta, sessenta dias? $E$ se isso se repetisse três a quatro vezes no ano? E ainda, se na instituição tivéssemos que nos resignar a sua dinâmica e fazer silenciar o nosso eu, os nossos desejos, os nossos direitos como nos mostrou também a mãe de João-deBarro, relatando o desespero do filho quando, ao chegar no hospital, foi impedido de entrar com seus pertences - uma sacola cheia das coisinhas boas que ele próprio preparou -, ou, como o que Sabiá contou sobre sua relação com alguém que cuidava dele: jogou-lhe uma toalha, deu-lhe umas roupas velhas e amassadas, e depois, colocou-o no colete e na CTI?

Esses "detalhes" do vivido são rotinas institucionais que chamam atenção para o nosso mundo de "lucidez", um mundo em que o outro da relação - aquele que vive uma condição por si esfaceladora e angustiante -, não participa (da relação) na condição de sujeito, o que intensifica seu malestar, reforçando a cada dia o lugar de (des)valor, de sujeitado, de menos humano, como se não fizéssemos parte da mesma condição humana.

Como seria se os projetos institucionais considerassem que a despersonalização e 0 distanciamento não contribuem para uma recomposição subjetiva e que uma sacola ou a permissão do uso de suas próprias roupas em espaço distante e desconhecido têm efeito simbólico e afetivo inigualável, por carregar em si um "pedacinho" da sua história? Essas e tantas outras inquietações, como a da espera por uma visita dos terapeutas de longa data no momento da internação, reforçam o quanto é nocivo ficar exposto a um afastamento dos seus vínculos e referenciais num período de tanta fragilidade.

A circularidade e a recorrência pelo mesmo circuito resultam mais, da falta de oportunidades de outros itinerários terapêuticos, do que dos parcos benefícios provenientes dos recursos disponibilizados. A constatação dominante é a de que a riqueza das trajetórias cotidianas não consegue abrir "brechas" no conjunto de prescrições metodicamente organizadas para 
"combater a doença", a exemplo do que nos mostrou João-de-Barro. O retorno à internação psiquiátrica por falta de respostas positivas para as novas exigências que essa situação de vida impõe, denuncia, traz à tona a precariedade de ofertas, o script da relação terapêutica, onde os papéis são dados, determinados e esperados sem que se considere a singularidade da vida como constitutiva dos projetos terapêticos.

Foi nesse campo de tensões que se constituíram tais trajetórias, fazendo com que cada universo singular tivesse marcas e ritmos peculiares criados pelas possibilidades de experimentar os diferentes espaços. Nessa construção histórica, ainda que existam as "não-escolhas", os sujeitos investem tempo em determinados planos de grande valor social, cultural e afetivo, mostrando que mesmo em presença do sofrimento, há sempre a produção de novos mapas existenciais.

Foi assim que vi em Beija-Flor mais do que em qualquer outro, como a rua permite diversidade para (re)compor os cenários velozes e por vezes imaginários do campo psíquico, dando novos sentidos à existência e concretizando projetos com tamanho valor social e subjetivo. Nesse cenário dinâmico pude apreender o seu investimento diário em torno de um modo de existência masculino, articulando gênero e trabalho, atributos que fazem parte da sua identificação com os códigos do lugar. No seu contexto de vida, apreendi o trabalho não como uma atividade econômica produtiva, mas com um caráter de legitimidade social.

Com Sabiá vivi mais de perto o desmoronamento de um território psicossocial. Observei como o processo inicial de uma crise, e as longas e sucessivas internações privaram-no das relações sociais e familiares, aprofundado as fissuras no processo de produção do eu e do mundo. Marcas que foram aparecendo ao olhar para trás e ver as lacunas deixadas pelos amigos, pelos irmãos, pelas festas que apareciam apenas como registro na sua memória. Após o retorno a uma casa quase "vazia", teve de tolerar um longo ciclo até a chegada do inverno quando a família (os irmãos) 
retorna "ao ninho", trazendo-lhe novamente o aconchego, a proteção e com isso, a reconstituição do seu território psicossocial e da sua autonomia.

João-de-Barro ensinou-me que a luta e a resistência contra as limitações oriundas da existência-sofrimento precisam ser constantes e dizem respeito a amplitude da vida. É ele que mais sente o esfacelamento de sua identidade. Sua experiência inquieta-o, desestabilizando-o emocionalmente de forma recorrente, o que tem tornado alguns momentos bastante difíceis, de grande confusão, e de poucos avanços em termos de uma ação terapêutica mais efetiva. Mas, ele fisga no contexto problemático que se delineia todas as possibilidades que acredita serem benéficas para sua recomposição, sendo o grande "cavador" do sistema de saúde e provando que a reivindicação e a persistência ainda que por vezes pouco toleradas, possibilitam uma rede mais densa e um lugar mais cidadão. No seu percurso merecem destaque a promotoria e a defensoria públicas que, como ele, perceberam, que as ofertas de saúde mental devem ser acompanhados de outras passagens articulando o mundo subjetivo e 0 espaço urbano.

Pomba-Rola fez-me sentir os limites de quem perdeu a possibilidade de encadear seu mundo ao mundo social pela presença do sofrimento. A convivência com longos anos de um funcionamento estranho/insólito e a difícil lida com essa condição humana parece ter trazido junto o fracasso dos papéis esperados para uma mulher da sua idade: o namoro, o casamento, a família. Apesar disso, esse é o campo que permite maior interlocução e sentido à sua existência. Pomba-Rola deixa explícita a necessidade de se analisar as questões de gênero construídas na vida familiar e social dessas pessoas.

Bem-te-Vi vive uma situação peculiar em relação aos demais. Mora em uma "pensão" distante da sua família biológica e faz um grande exercício para alargar suas redes de sociabilidade. Com a vizinhança, apesar das restrições impostas para sair de casa, consegue estabelecer relações acolhedoras e de trabalho, mas é com o serviço de saúde que se instaura a 
grande novidade nesse contexto, quando o mesmo capta e, em alguma medida, investe no trabalho de office boy, permitindo-lhe a abertura para o exterior, onde reencontra a possibilidade de produzir obras, valor social, afetividade e liberdade.

Assim se entrecruzam temas que expressam o desejo de viver e de pertencer a um lugar social, que falam da luta para evitar perdas (de referências) surgidas por ocasiāo do adoecimento (buscando a preservação e reconstrução da identidade), da associação aos códigos do lugar (trabalho, gênero, família, religião), da manutenção e do fortalecimento dos vínculos sociais (trocas, alianças, interações na rede social) e da busca de autonomia e liberdade para circular e reconstruir suas experiências, tanto subjetiva, como objetivamente.

$\mathrm{Na}$ riqueza desse percurso, evidenciamos que as inter-relações vividas nos espaços da cidade tornavam-se os focos mais ativos de subjetivação desses sujeitos, pois é nessas circunstâncias que eles aprendem regras, constroem estratégias, exercem trocas, forjam alianças, driblam as repressões, criam saídas ou, no limite, mantém-se conectados ao território imaginário, como a via possível para sobreviver ao turbilhão do adoecimento. A incorporação do espaço público não se coloca em oposição aos demais, mas como parte fundamental das estratégias mais amplas de suas vidas. Dessa forma, trazer a cidade como espaço de prática,- que pode se desdobrar em ação terapêutica mais estruturada e/ou não - faria a vida ganhar outras dimensões não só para as pessoas em sofrimento e suas famílias, como para todos os envolvidos no universo dos serviços de saúde mental, provocando, acredito, grandes rupturas no modelo vigente.

Do ponto de vista da prática terapêutica, essa ganharia mais consistência por possibilitar um encontro entre os territórios geográfico e existencial onde nasce uma força de produção de modos de ser e de sentir, uma arena de subjetividades tecidas nessa relação intersubjetiva no espaço da cidade, que permite agregar pessoas, signos, fatos, acontecimentos, 
emoções, sentimentos, normas, solidariedade, constituindo-se em potentes roteiros de passagem.

Essa análise ajuda ainda, a pensar o território, conceito "engessado" na prática dos serviços, por girar mais em torno da necessidade da instituição de saúde e menos do sentido produzido na vida das pessoas do local, perdendo de vista toda a sensibilidade dessa lógica impressa no cotidiano. Essa situação complexa e conflituosa pode apresentar-se como uma grande oportunidade para os profissionais dos diferentes serviços de saúde problematizarem suas concepções e práticas, e posicionarem-se de outro lugar onde a instabilidade, as incertezas, a desorganização e a reorganização fazem parte da história a ser apreendida a cada momento, a cada nova situação. Assim, seria possível criar novos papéis, novos sentidos, buscando superações do que, há muito, não responde ao universo dos "usuários" de saúde mental do municipio, que se sentem inseguros e desrespeitados pela falta de responsabilização das instituições para com eles e pelas suas problemáticas.

O desafio consiste em desenvolver "tecnologias de saúde" que possibilitem tecer, junto com o sujeito, novas redes, novos itinerários para os quais "seus investimentos façam sentido, de tal modo que a subjetividade petrificada possa vir a vitalizar-se, e o que era desejo despotencializado seja reativado, buscando fisgar nas próprias trajetórias, "elementos que possam eventualmente funcionar como componentes dessas redes; identificar focos susceptiveis de fazer a existência do (sofredor psíquico) bifurcar em novas direções, de modo que territórios de vida possam vir a ganhar consistência" (Rolnik, 2000, 91)". É desses enlaces do sujeito com o campo sócio-cultural que, acredito, seja possivel a criação de novos itinerários de mais ruas que clausuras, mais fluxos que fixos, mais escuta que contenções, mais acolhimento que retórica, mais sensibilidade que protocolos, mais colorido que escuridão, mais resistência que subordinação, mais tensão que passividade, mais diversidade que normalização, mais metamorfose que estagnação, mais autonomização que passatempo e, para além da doença e 
do sofrimento, mais saúde, mais alteridade, mais subjetividades autônomas e livres... para o mundo "psi".

A partir dessa perspectiva acredito, seja necessário que os serviços de saúde mental aprofundem discussões acerca da real missão de cada um para com a população que sente e sofre mentalmente, sobretudo quando se trata de equipamentos "substitutivos". Devemos reconhecer a necessidade da presença e intervenção das instituições de saúde mental, nos diferentes momentos e situações da vida desse sujeito e de suas famílias, preservando, no entanto, os vínculos e comprometendo-se desde o resguardo e proteção, quando a crise se intensifica, até o apoio às possibilidades de autonomização de suas ações, afirmando-o como um sujeito de direitos.

Cabe também ressaltar a importância e o desafio de recompor as estruturas da formação universitária, sobretudo onde estou inserida, pensando em outros lugares (sociais, geográficos, afetivos, terapêuticos) para os sujeitos e sua atenção à saúde. As necessidades dos nossos protagonistas parecem não comportar mais a forma tradicional de cuidado, uma vez que essa reduz a complexidade da vida a um quadro nosológico, enquanto que, essa experiência abarca todo o seu contexto de relações e, por isso, requer recursos múltiplos, criativos e transdisciplinares.

Não poderiamos deixar de destacar a importância das interações familiares, tanto para o cuidado cotidiano de aspectos bem específicos do tratamento, quanto para suas persistências em enfrentar os desafios que a vida lhes impõem. Nessa direção, identificamos a premência em que se dê suporte terapêutico para que os familiares possam cuidar, proteger e aliviarse da sobrecarga vivida, possibilitando-Ihes a construção de outros recursos para lidarem com seus parentes adoecidos de forma mais livre e autônoma.

É nesse palco de contradições e sobre esse fio chamado "vida" que os nossos personagens-tipo vão equilibrando, passo a passo, suas trajetórias, fonte de alimentação para fazer frente aos inúmeros desafios de um mundo ainda pouco protagonizado por eles. É nessa "corda bamba", 
nesse desassossego, por vezes tão doloroso, que eles nos mostram o encanto pela vida e pela liberdade, e também, nos fazem vislumbrar a esperança equilibrista de encontrarmos outros lugares cada vez mais dignos e condizentes com a complexa trama da vida.

Aqui chegando, percebo o quanto meu mundo também ganhou novas dimensões. Esse, sem dúvida, é o início de um trabalho que mudou o meu lugar de pessoa e de profissional da saúde mental... 


\section{REFERÊNCIAS}

ADORNO, R. C. F.; CASTRO, A. L de. O exercicio da sensibilidade: pesquisa qualitativa e a saúde como qualidade. Rev. Saúde e Sociedade. São Paulo, v. 3, n, 2, p. 172-185,1994.

AGUIAR, M. G. G. A reinvenção do ser enfermeira no cotidiano da casa de saúde Anchieta e núcleos de atenção psicossocial. São Paulo, 1995. 155 f. Dissertação (Mestrado em Enfermagem) - Escola de Enfermagem, Universidade de São Paulo.

ALVES, P. C. B.; SOUZA, I. M. A. Escolha e avaliação de tratamento para problemas de saúde: considerações sobre o itinerário terapêutico. In: RABELO, M, C. M.; ALVES, C. B. A.; SOUZA, I. M. A. Experiência de doença e narrativa. Rio de Janeiro: Fiocruz, 1999. p. 125-138.

AMARANTE, P. (org.) Loucos pela vida: a trajetória da reforma psiquiátrica no Brasil. Rio de Janeiro: Panorama ENSP, 1995.

AMARANTE, P. A psiquiatria enquanto Ideologia: conceitos sobre a dimensão negativa. Disponivel em: <http://www.dietanet.hpg.ig.com.br/npsiquiatria.htm>. Acesso em: 10 nov. 2003.

AMARANTE, P. A. A (clínica) e a reforma psiquiátrica. In: AMARANTE, P. (coord.) Archivos de Saúde Mental e Atenção Psicossocial. Coleção Archivos, Rio de Janeiro, v.1, p. 45-65, jul. 2003b.

AMARANTE, P. O homem e a serpente: outras histórias sobre a loucura e a psiquiatria. Rio de Janeiro: Fiocruz, 1996.

AMARANTE, P. Projeto Memória da Psiquiatria no Brasil: catálogo de periódicos não-correntes em psiquiatria da Biblioteca de Manguinhos. Rio de Janeiro: Fiocruz, 2001. CD ROM.

AUGE, M. Não-lugares: introdução a uma antropologia da supermodernidade. 2 ed. São Paulo: Papirus/Travessia do Século, 2001.

ÁREA da saúde lidera demandas da Defensoria. Jornal Diário da Manhã, Arquivo DM, Passo Fundo, 11 fev. 2003, p. 3.

BARROS, Denise. Jardins de Abel: desconstrução do manicômio de Trieste. São Paulo: EDUSP, Lemos, 1994.

BARROS, S. O louco, a loucura e a alienação institucional: o ensino de enfermagem sob judice. São Paulo, 1996. 202 f. Tese (Doutorado em Enfermagem) - Escola de Enfermagem, Universidade de São Paulo.

BASÁGLIA, F. et al. Considerações sobre a experiência comunitária. (Tradução de Luiz Cavelhieri Filho). In: AMARANTE, P (org). Psiquiatria social e reforma psiquiátrica. Rio de Janeiro: Fiocruz, 1994. p. 11-40. 
BASÁGLIA, F. A Instituição negada. 2 ed. Rio de Janeiro: Graal, 1991.

BASÁGLIA, F. A psiquiatria alternativa: contra o pessimismo da razão e o otimismo da prática. São Paulo: Brasil Debates,1980.

BENICÁ, E. (org.) Religiosidade \& saúde popular. Passo Fundo: Editora UPF, 1991.

BIRMAN, J. A psiquiatria como discurso da moralidade. Rio de Janeiro: Graal, 1978.

BIRMAN, J. e COSTA, J. F. Organização de Instituições para uma psiquiatria comunitária. In: AMARANTE, $\mathrm{P}$ (org). Psiquiatria social e reforma psiquiátrica. Rio de Janeiro: Fiocruz, 1994. p. 41-72.

BIRMAN, J. Malestar na atualidade: a psicanálise e as novas formas de subjetivação, 3 ed. Rio de Janeiro: Civilização Brasileira, 2001.

BRANDÃO, C. R. Partilha da vida. São Paulo: Cabral, 1995.

BRASIL. Constituição da República Federativa do Brasil. Brasília, DF: Senado, 1988.

BRASIL. Secretaria Nacional de Assistência à Saúde, 1991. Portaria $n^{\circ} 189$, de 19 de novembro de 1991. In: SUS-RS: Descentralizando e democratizando o conhecimento. Porto Alegre: Editora Nova Prata, 1996.

BRASIL. Secretaria Nacional de Assistência à Saúde, 1992. Portaria $n^{\circ} 224$, de 29 de janeiro de 1992. In: SUS-RS: Descentralizando e democratizando o conhecimento. Porto Alegre: Editora Nova Prata, 1996.

BRASIL. Lei de $n^{\circ} 10.216$, de 06 abr. 2001. Dispõe sobre a proteção e os direitos das pessoas portadoras de transtornos mentais e redireciona o modelo assistencial em saúde mental. Diário Oficial da União, Brasilia, DF, 09 abr. $2001 . \quad$ Disponivel em: <http://portalweb01.saude.gov.br/saude/visao.cfm>. Acesso em: 15 jan. 2004.

BRASIL. Ministério da Saúde. Informações em Saúde. Sistema de Internações Hospitalares SIH-SUS. Disponível em: <http://www.datasus.gov.br>. Acesso em 10 nov. 2001.

BRASIL. Portaria de $n^{\circ} 336 / \mathrm{GM}$, de $19 \mathrm{fev}$. 2002. Define as normas e diretrizes para a organização dos serviços que prestam assistência em saúde mental. Diário Oficial da União, Brasília, DF, 20 fev. 2001. Disponivel em: <http://portalweb01.saude.gov.br/saude/visao.cfm>. Acesso em 15 jan. 2004.

BRASIL. Portaria n. ${ }^{\circ}$ 2391/GM de 26 dez. 2002. Regulamenta o controle das internações psiquiátricas. Diário Oficial da União, Brasilia, DF, 27 dez. $2001 . \quad$ Disponivel em: <http://dtr2001.saude.gov.br/sas/PORTARIAS/Port2002/Gm/GM-2391.htm>. Acesso em 14 dez. 2003.

CAMARGO, E. M. C de. O acompanhante terapêutico e a clínica. In: EQUIPE DE ACOMPANHANTES TERAPÊUTICOS DO HOSPITAL-DIA A 
CASA. A rua como espaço clínico: acompanhamento terapêutico. São Paulo: Escuta, 1991. p. 51-60.

CAMPOS, F. C. B.; HENRIQUES, C. M. P. (orgs.) Contra a maré à beiramar: a experiência do SUS em Santos. São Paulo: editora página aberta Itda., 1996.

CAROSO, C.; RODRIGUES, N.; ALMEIDA FILHO, N. Manejo comunitário em saúde mental e experiência da pessoa. Horizontes Antropológicos, Porto Alegre, ano 4, n. 9, p. 63-83, out. 1998.

CARROZZO, N. Introdução. In: EQUIPE DE ACOMPANHANTES TERAPEUTICOS DO HOSPITAL-DIA A CASA (orgs,). Crise e cidade: acompanhamento terapêutico. São Paulo: Educ, 2000. p. 11-15.

CASTEL, R. A ordem psiquiátrica: a idade de ouro do alienismo. Rio de Janeiro: Graal, 1978.

CENTRO DE ESTUDOS E AÇÃO DA MULHER URBANA E RURAL. Nova Friburgo/RJ. Disponivel em: <http://www.sermulher.org.br>. Acesso em: 12 out. de 2003.

CERCA de 100 pessoas por mês aguardam internação no Hospital Psiquiátrico Bezerra de Menezes. Jornal Diário da Manhã, Arquivo DM, Passo Fundo, 27 e 28 jan. 2001. p. 3.

CERTEAU, M. A cultura no plural. São Paulo: Papirus/Travessia do século, 1995.

CERTEAU, M. A invenção do cotidiano: artes de fazer. 8. ed. Petrópolis: Vozes, 2002.

CERTEAU, M.; GIARD, L. e MAYOL. A invenção do cotidiano: morar, cozinhar. 3 ed. Petrópolis: Vozes, 2000.

CHAUI, M. Cultura e Democracia. 5 ed. São Paulo: Cortez, 1990.

CINTRA, A, R. de L. De médico e louco todo o mundo tem um pouco: convivendo com a esquizofrenia na vida cotidiana. São Paulo, 2001. $103 \mathrm{f}$. Dissertação (Mestrado em Psicologia Social) - Programa de Pós-graduação em Psicologia Social, Pontifícia Universidade Católica de São Paulo.

CLASSIFICAÇÃO dos Transtornos Mentais e Comportamentais, décima versão, CID 10 - Organização Mundial da Saúde - OMS, Porto Alegre: Artes Médicas, 1993.

COMUNIDADE faz campanha e ajuda o hospital. Jornal Zero Hora, Porto Alegre, 29 mar. 1999. p. 48.

CONFERENCIA MUNICIPAL DE SAÚDE DE PASSO FUNDO, 4., Passo Fundo, 2003. Relatório Final. Passo Fundo: Conselho Municipal de Saúde, 2003.

CONFERENCIA NACIONAL. DE SAÚDE MENTAL, 1., Brasília, 1987. Relatório Final. Brasília: Ministério da Saúde, 1988. 
CONFERENCIA NACIONAL DE SAÚDE MENTAL, 2., Brasília, 1992. Relatório Final. Brasilia: Ministério da Saúde, 1994.

COSTA-ROSA, A.; LUZIO, C. A. e YASUI, S. As Conferências Nacionais de saúde mental e as premissas do modo psicossocial. Revista Saúde em debate. v. 25, n. 58, p. 12-25, maio/ago. 2001.

COSTA-ROSA, A. LUIZIO, C. A, e YASUI, S. Atenção Psicossocial: rumo a um novo paradigma na saúde coletiva. Achivos de saúde mental e atenção psicossocial.Coleção Archivos, Rio de Janeiro, v. 1, p. 13-44, jul. 2003.

DALMOLIN, B. M.; AGOSTINI, A. P.;BINSFILD e WEGHER, M. Atenção à saúde mental na região e a reforma psiquiátrica. Revista Médica, Passo Fundo, ano XVI, n. 31, jul./dez., p. 64-68, 2002.

DALMOLIN, B. M. "Beira-trilho" - Grande Vera Cruz, Passo Fundo, RS. 2004. 1 fotografia

DALMOLIN, B. M. Construções típicas do bairro Vera Cruz, Passo Fundo/RS. 2004. 1 fotografia

DALMOLIN, B. M. Crianças jogando bola no final da tarde. Rua Uruguaiana - Bairro Vera Cruz, Passo Fundo/RS. 2004. 1 fotografia

DALMOLIN, B. M. Vista da rua São Sebastião. Bairro Vera Cruz, Passo Fundo/RS. 2004. 1 fotografia

DALMOLIN, B. M. Vista parcial da rua Santana - Bairro Vera Cruz, Passo Fundo/RS. 2004. 1 fotografia

DELEUZE, G. GUATTARI, F. O Anti-Édipo. Rio de Janeiro: Imago, 1976.

DOAÇÕES mudam a situação do Hospital Psiquiátrico Bezerra de Menezes. Jornal O Nacional, Arquivo ON, Passo Fundo, 02 fev. 1999. p. 7.

DUARTE, L, F. Da vida nervosa nas classes populares brasileiras. Rio de Janeiro: Jorge Zahar, 1986.

DUARTE, L. F. D. Investigação Antropológica sobre doença, sofrimento e perturbação: uma introdução. In: DUARTE, L. F. D. e LEAL, O. F. (orgs.) Doença, sofrimento, perturbações: perspectivas etnográficas. Rio de Janeiro: Fiocruz, 1998. p. 9-27.

EQUIPE DE ACOMPANHANTES TERAPÊUTICOS DO HOSPITAL-DIA A CASA (orgs.). A rua como espaço clínico: acompanhamento terapêutico. São Paulo: Escuta, 1991.

EQUIPE DE ACOMPANHANTES TERAPEUTICOS DO HOSPITAL-DIA A CASA (orgs,). Crise e cidade: acompanhamento terapêutico. São Paulo: Educ, 2000.

FALTAM leitos no Hospital Psiquiátrico. Jornal 0 Nacional, Arquivo ON, Passo Fundo, 16 e 17 mar. 2002. p. 4.

FERRAZ, F. Andarilhos da imaginação. São Paulo: Casa do psicólogo, 2000. 
FÓRUNS DE ENTIDADES NACIONAIS DE DIREITOS HUMANOS. Texto base as IX Conferencia Nacional de Direitos Humanos. 2004. Disponivel em <http://www.conferencia.direitos.org.br>. Acesso em: 21 maio 2004.

FOUCAULT, M. História da loucura na idade clássica. 4 ed. São Paulo: Perspectiva, 1995.

FREIRE, P. Educação e mudança. Rio de Janeiro: Paz e terra, 1998.

FUNDAÇÃO IBGE. Anuário estatístico do Brasil. 2000. Disponível em: $<$ http://www.ibge.gov.brl>. Acesso em 20 jan. 2003.

GALLI, A. V. Planejamento, diagnóstico e programação em saúde: um enfoque estratégico. Mimeo, 1986.

GEERTZ,C. A interpretação das culturas. Rio de Janeiro: Guanabara Koogan, 1989.

GOFFMAN, E. Manicômio, prisões e conventos. 7 ed. Rio de Janeiro: Perspectiva, 2001.

GOFFMAN, E. Estigma. 4 ed. Rio de Janeiro: Guanabara, 1988.

GOLDBERG, J. Clínica da psicose: um projeto na rede pública. 2 ed. Rio de Janeiro: Te corá, 1996.

GONZÁLEZ REY, F. L. Pesquisa qualitativa em psicologia. São Paulo: Thomson pioneira, 2002.

GONZÁLEZ REY, F. L. Sujeito e subjetividade. São Paulo: Pioneira Thomson, 2003.

GUATARRI, F. Caosmose: um novo paradigma ético-estético. São Paulo: Editora 35, 1992.

GUATARRI, F. Revolução molecular: pulsões politicas do desejo. São Paulo: Brasiliense, 1986.

GUATTARI, F. Desejo e história. In: GUATTARI, F. ; ROLNIK, S. Micropolítica: cartografias do desejo. 6 ed. Petrópolis: Vozes, 2000. p. 197273.

GUATTARI, F. ROLNIK, S. Micropolítica: cartografias do desejo. 6 ed. Petrópolis: Vozes, 2000.

HIRDES, A. Reabilitação Psicossocial: dimensões teórico-práticas do processo. Erechim: EDIFAPES, 2001.

HOSPITAL Bezerra de Menezes com fila de espera. Jornal Diário da Manhã, Arquivo DM, Passo Fundo, 26 abr. 2002. p. 7.

HOSPITAL Bezerra de Menezes realiza campanha para enfrentar dificuldades. Jornal Diário da Manhã, Arquivo DM, Passo Fundo, 06 ago. 1998. p. 9.

HOSPITAL Bezerra de Menezes vai receber recursos da Secretaria da Saúde do Estado. Jornal Diário da Manhã, Arquivo DM, Passo Fundo, 23 set. 1998. 
HOSPITAL DA CIDADE/HOSPITAL PSIQUIÁTRICO BEZERRA DE MENEZES. Passo Fundo. Ata de $n^{\circ} 122$ de 20/12/1999.

HOSPITAL DA CIDADE/HOSPITAL PSIQUIÁTRICO BEZERRA DE MENEZES. Projeto Terapêutico do Hospital Psiquiátrico Bezerra de Menezes. Passo Fundo, 2003.

HOSPITAL ESPÍRITA BEZERRA DE MENEZES. Passo Fundo. Ata da assembléia geral extraordinária, realizada em 14/07/89.

HOSPITAL ESPIRITA BEZERRA DE MENEZES. Passo Fundo. Ata de inauguração do hospital de $n^{\circ} 10$ de 24/03/1990.

HOSPITAL ESPÍRITA BEZERRA DE MENEZES. Passo Fundo. Ata de $n^{\circ} 13$ de 10/12/1993.

HOSPITAL ESPÍRITA BEZERRA DE MENEZES. Passo Fundo. Ata de $n^{\circ} 14$ de 30/12/1993.

JUDICIÁRIO diz que gerencia a saúde e MP entra com ação contra o governo. Jornal Diário da Manhã, Arquivo DM, Passo Fundo, 08 e 09 nov. 2003. p. 13.

KANTORSKI, L. P. O ensino de enfermagem psiquiátrica e saúde mental e a reforma psiquiátrica no Rio Grande do Sul. Ribeirão Preto, 1998. 214 f. Tese (Doutorado em Enfermagem) - Escola de Enfermagem de Ribeirão Preto, Universidade de São Paulo.

LOBOSQUE, A. M. Experiências da loucura. Rio de Janeiro: Garamond, 2001.

LOBOSQUE, A. M. Clínica em movimento: por uma sociedade sem manicômios. Rio de Janeiro: Garamond, 2003.

LOBOSQUE, A. M. Princípios para uma clínica antimanicomial. Rio de Janeiro: Hucitec, 1997.

LUZ, M. A produção cientifica em ciências sociais: notas preliminares. Saúde em debate, v. 24, n. 55, p. 54-68, maio/ago. 2000.

MACHADO, A. C. L. Universo em desencanto: conceitos, imagens e fantasias de pacientes psiquiátricos sobre loucura e/ou doença mental. São Paulo, 1995. 439 f. Tese (Doutorado em Psicologia Clínica) - Instituto de Psicologia, Universidade de São Paulo.

MACIEL, E. N. Gênero, trabalho e família: a construção de espaços femininos na periferia urbana. Passo Fundo: EDIUPF, 2001.

MAGNANI, J. G. C. A antropologia urbana e os desafios da metrópole. Tempo Social: Revista de Sociologia da USP, v. 15, n. 1, p. 81-95, maio. 2003.

MAGNANI, J. G. C. De perto e de dentro: nota para uma etnografia urbana. Revista brasileira de ciências sociais, v. 17, n. 49, p. 11-29, jun. 2002.

MAGNANI, J. G. C. Mystica urbe: um estudo antropológico sobre o circuito neo-esotérico na metrópole. São Paulo: Studio Nobel, 1999. 
MAGNANI, J. G. C. Quando o campo é a cidade: fazendo antropologia na metrópole. In: MAGNANI, J. G.; TORRES L. de L. (org.) Na metrópole: textos de antropologia urbana. 2 ed. São Paulo: Edusp/Fapesp, 2000. p. 1253.

MALINOWSKI, B. Objetivo, método e alcance da pesquisa. In: GUIMARÃES, A. Z. Desvendando mascaras sociais. Rio de Janeiro: Francisco Alves, 1980. p. $39-61$.

MAPA do Estado do Rio Grande do Sul. Disponível em: http://www.guianet.com.br/rs/mapars.htm>. Acesso em:03 jun. 2004.

MARCOLAN, A. V. Da emergência psiquiátrica à emergência do sujeito: alguns atravessamentos. Cadernos de Texto da III Conferencia Nacional de Saúde Mental. dez. 2001, p. 153-159. Disponivel em: <http://www.cdsm.ufes.br/files/Cadernos.pdf>. Acesso em: 12 dez. 2003.

MARTINS, J. B. Identidade profissional e a produção do conhecimento antropológico: a questão da implicação. Disponivel em: <http://www.naya.org.ar/congreso2000/ponencias>. Acesso em: 20 mar. 2003.

MELMMAN J. Família e doença mental: repensando a relação entre profissionais de saúde e familiares. São Paulo: Escrituras, 2001.

MORIN, E. Ciência com consciência. 2 ed. Rio de Janeiro: Berhand Brasil, 1998.

MORIN, E.; LE MOIGNE, J. L. A inteligência da complexidade. 2 ed. São Paulo: Peirópolis, 2000.

MORIN, E. Introdução ao pensamento complexo. Lisboa: Instituto Piaget, 1990.

MORIN, E. Os sete saberes necessários à educação do futuro. São Paulo/Brasilia: Cortez/UNESCO, 2000.

OLIVEIRA, C. Centro Comunitário de Saúde Mental: um mutirão por uma psicologia solidária. Jornal Mutirão, Passo Fundo, Ano I, n. 1, 1983.

ORGANIZAÇÃO DAS NAÇÕES UNIDAS. Declaração Universal dos Direitos Humanos. (Adotada e proclamada pela resolução 217 A (III) da Assembléia Geral das Nações Unidas em 10 de dezembro de 1948.). Disponivel em: http://www.mj.gov.br/sedh/dpdh/gpdh/ddh bib inter universal.htm>. Acesso em: 21 dez. 2003.

ORGANIZAÇÃO MUNDIAL DA SAÚDE. Relatório sobre a saúde no mundo - Saúde mental: nova concepção, nova esperança. Genebra, 2001.

ORGANIZAÇÃO PAN-AMERICANA DE SAÚDE/ORGANIZAÇÃO MUNDIAL DA SAÚDE. Declaração de Caracas. In: CONFERENCIA SOBRE A REESTRUTURAÇÃO DA ATENÇÃO PSIQUIÁTRICA NA AMÉRICA LATINA. Caracas, 14 nov. 1990. 
PANDJIARJIAN, C. Acompanhamento terapêutico: imagens em movimento. In:EQUIPE DE ACOMPANHANTES TERAPEUTICOS DO HOSPITAL-DIA A CASA (orgs,). Crise e cidade: acompanhamento terapêutico. São Paulo: Educ, 2000. p. 61-70.

PASSO FUNDO. Secretaria do Planejamento. Mapa de Passo Fundo (Traçado). 2004. 1 mapa.

PASSO FUNDO. Secretaria Municipal de Saúde. Projeto Centro de Atenção Psicossocial. 2000.

PEIRANO, M. A favor da Etnografia. Rio de Janeiro, Relume-Dumará, 1992.

PESSOTTI. I. A Loucura e as épocas. Rio de Janeiro: Ed. 34, 1994.

PICCOLO, F. D. Particularidades e generalizações: reflexões a partir da pesquisa urbana entre usuários de drogas em Porto Alegre. In: VELHO, G. KUSCHNIR, K. (orgs.). Pesquisas Urbanas: desafios do trabalho antropológico. Rio de Janeiro: Jorge Zahar, 2003. p. 55-68.

PICHON-RIVIĖRE, E. O processo grupal. 3 ed. São Paulo: Martins Fontes, 1988.

PITTA, A.M.F. (org.) Reabilitação Psicossocial no Brasil. São Paulo: Hucitec, 1996.

PITTA, A.M.F. Apresentação. In: MELMMAN J. Família e doença mental: repensando a relação entre profissionais de saúde e familiares. São Paulo: Escrituras, 2001. p.11-13.

PITTA, A.M.F. Reorientação do Modelo de Atenção em Saúde Mental: equidade e justiça social na organização dos serviços de saúde mental. Cadernos de Texto da III Conferencia Nacional de Saúde Mental. Dez. 2001, p. 20-30. Disponível em: <http://www.cdsm.ufes.br/files/Cadernos.pdf>. Acesso em: 12 dez. 2003.

RABELO, M, C. M.; ALVES, C. B. A.; SOUZA, I. M. A. Experiência de doença e narrativa. Rio de Janeiro: Fiocruz, 1999.

REINALDO, A. M dos S. Conhecendo o itinerário Terapêutico em saúde mental pela história oral de vida do paciente psiquiátrico. Ribeirão Preto, 2003. 112 f. Dissertação (Mestrado em Enfermagem) - Escola de Enfermagem de Ribeirão Preto, Universidade de São Paulo.

RESTREPO, L. C. $O$ direito à ternura. 3 ed. São Paulo: Vozes, 2001.

RIO GRANDE DO SUL. Lei de $n^{0}$ 9.716, de 07 ago. 1992. Dispõe sobre a reforma psiquiátrica no Rio Grande do Sul e dá outras providencias. Diário Oficial do Estado, Porto Alegre, RS, 07 ago.1992.

RIO GRANDE DO SUL. Poder Judiciário. 4. vara civil. Passo Fundo. Processo judicial número: 02101249945 de $11 \mathrm{dez} .2003$.

RIO GRANDE DO SUL. Secretaria de Saúde e Meio Ambiente- Inamps. Manual de Treinamento em cuidados primários de Saúde Mental. 1981 (Documentos SSMA-RS). 
RIO GRANDE DO SUL. Secretaria de Saúde e Meio Ambiente. Delineamentos para a Elaboração da Política de Saúde Mental para o Rio Grande do Sul, 1989. (Documentos SSMA-RS).

ROCHA, R. M. Enfermagem Psiquiátrica: que papel é este? Rio de Janeiro, Instituto Franco Baságlia/Te Corá, 1994.

ROCHA, R.M. Trajetórias terapêuticas de usuários de serviços psiquiátricos e adeptos da umbanda: um estudo sobre o pluralismo terapêutico. Revista. de Enfermagem UFRJ, v. 8, n. 2, p. 73-7, 2000.

ROLNIK, S. Apresentação. In: GUATTARI, F. ROLNIK, S. Micropolítica: cartografias do desejo. 6 ed. Petrópolis: Vozes, 2000. p. 11-14.

ROLNIK, S. Cartografias sentimental: transformações contemporâneas do desejo. São Paulo: Estação liberdade, 1989.

ROLNIK, S. Clínica Nômade. In:EQUIPE DE ACOMPANHANTES TERAPEUUTICOS DO HOSPITAL-DIA A CASA (orgs,). Crise e cidade: acompanhamento terapêutico. São Paulo: Educ, 2000. p. 83-97.

ROLNIK, S. Psicologia, subjetividade, ética e cultura. In: SILVA, A. do E. et al. (orgs.) Saúde e loucura 6. São Paulo: Hucitec,1997. p. 13-21.

ROTELLI, F. LEONARDIS, O .MAURI, D. Desinstitucionalizacão, uma outra via. In: NICÁCIO, F. (Org. ). Desinstitucionalizacão. São Paulo: Hucitec, 1990. p.17-59.

SAHLINS, M. O 'pessimismo sentimental' e a experiência etnográfica: porque a cultura não é um 'objeto' em extinção (Parte I). Mana, v. 3, n. 1, p. 41-73, abr. 1997.

SANTOS, M. (Organização RIBEIRO, W. C.). O país distorcido: o Brasil, a globalização e a cidadania. São Paulo : Publifolha, 2002.

SAMPAIO, J. J. Epidemiologia da imprecisão. Rio de Janeiro: Fiocruz, 1998.

SARACENO, B. Libertando Identidades: da reabilitação psicossocial à cidadania possível. Belo Horizonte/Rio de Janeiro: Instituto Franco Baságlia, 1999.

SARACENO, B. Reabilitação psicossocial: uma estratégia para a passagem do milênio. In: PITTA, A. (org.) Reabilitação psicossocial no Brasil. São Paulo: Hucitec, 1996. p 13-18.

SCALI JÚNIOR, D. A. Retratos de subjetivação: nuanças da migração campo-cidade pequena/metrópole. São Paulo: Casa do Psicólogo, 2002.

SILVA, A. L. O projeto copiadora do Caps: do trabalho de reproduzir cópias ao trabalho de produção de vida. São Paulo, 1997. 131 f. Dissertação (Mestrado em Enfermagem) - Escola de Enfermagem, Universidade de São Paulo.

SILVEIRA, M. L. O nervo cala, o nervo fala: a linguagem da doença. Rio de Janeiro: Fiocruz, 2000. 
SIMMEL, G. Metrópole e vida mental. In: VELHO, G. (org.) O fenômeno Urbano. Rio de Janeiro: Zahar, 1979.

SOUZA, I. M. A. O asilo revisitado:perfis do hospital psiquiátrico em narrativas sobre doença mental. In: RABELO, M. R.; ALVES, P. C.B.; SOUZA, I. M. S. Experiência de doença e narrativa. Rio de Janeiro: Fiocruz, 1999, p. 139-168.

SPINK, P. K. Pesquisa de campo em psicologia social: uma perspectiva pósconstrucionista. Rev Psicologia e Sociedade, Porto Alegre, v. 15, n. 2, p. 18-42, jul./dez. $2003 \quad$ Disponivel em: $<$ http://www.scielo.br/scielo.php?script=sci_arttext\&pid=S0102$71822003000200003 \&$ Ing=pt\&nrm=iso\&tlng=pt>. Acesso em: 30 abr. 2004.

SPINK, M. J. e MEDRADO, B. Produção de sentido no cotidiano: uma abordagem teórico-metodológica para análise das práticas discursivas. In: SPINK, M. J. (org.). Práticas discursivas e produção de sentidos no cotidiano: aproximação teóricas e metodológicas. 2 ed. São Paulo: Cortez, 2000.

SZASZ, T. A fabricação da loucura. Rio de Janeiro: Zahar, 1976.

TELLEGEN, T. A. Gestalt e grupos: uma perspectiva sistêmica. 4 ed. São Paulo: Summus, 1984.

UNIVERSIDADE DE PASSO FUNDO. Curso de Enfermagem. Relatório da disciplina de Saúde Pública do curso de enfermagem. Passo Fundo, 2001.

VASCONCELLOS, M. P. C. Os (des)caminhos da formação sanitária e os direitos sociais. São Paulo; 2000. 183 f. Tese (Doutorado em Saúde Pública) - Faculdade de Saúde Pública, Universidade de São Paulo.

VELHO, G. Metamorfose e projeto: antropologia das sociedades complexas. Rio de Janeiro: Jorge Zahar, 1994.

VENTURINI, E. A qualidade do gesto louco na era da apropriação e da globalização. In: AMARANTE, P. (coord.) Archivos de Saúde Mental e Atenção Psicossocial. Coleção Archivos. Rio de Janeiro. v.1, p. 157-184, jul. 2003.

VICTORA, C. G. KNAUTH, D. R. HASSEN, M, de N. Pesquisa qualitativa em saúde: uma introdução ao tema. Porto Alegre: Tomo, 2000.

ZAGO, A. P.; RAMOS, C. C. P. e OKI, N. Unidade de atenção à crise: repensando a prática de internação em saúde mental. In: HARARI, A. VALENTINI, W. (orgs.) A reforma psiquiátrica no cotidiano. São Paulo: Hucitec, 2001. p. 71-103. 


\section{ANEXOS}


Passo Fundo, 10 de maio de 2003

\section{A (Instituição)}

\section{TERMO DE AUTORIZAÇÃO}

Pelo presente termo, solicitamos sua autorização para acesso da pesquisadora Bernadete Maria Dalmolin, a documentos que historiem a construção e viabilização do Hospital Psiquiátrico Bezerra de Menezes/Passo Fundo, como também a seu projeto terapêutico atual, para o desenvolvimento da pesquisa "CARTOGRAFIAS DE SUJEITOS QUE VIVENCIAM O SOFRIMENTO PSIQUICO EM UMA COMUNIDADE URBANA".

Trata-se de um projeto de pesquisa de doutorado realizado junto à Faculdade de Saúde Pública da Universidade de São Paulo/SP, sob a orientação da Professora Dra. Maria da Penha Costa Vasconcellos, tendo como objetivo central compreender como o sujeito que vivencia a situação de sofrimento psiquico constrói suas experiências nas dimensões da cidade, partindo do interior de uma comunidade urbana, de onde são oriundos muitos usuários de serviços de saúde mental do município.

A pesquisa nos documentos solicitados tem o objetivo de complementar informações sobre o contexto dos serviços de saúde mental no município de Passo Fundo/RS.

Certos de sua colaboração nos colocamos a disposição para quaisquer esclarecimentos que se façam necessários.

\section{Atenciosamente,}

Prof. Dra. Maria da Penha Costa

Vasconcellos

Orientadora

Tel.(011) 3066-7702 3066-7773

Faculdade de Saúde Pública

Universidade de São Paulo

Av. Dr. Arnaldo, $7152^{\circ}$.

CEP 01246-904 - São Paulo
Bernadete Maria Dalmolin

Doutoranda em Saúde Pública da FSP/USP

Tel. (054) 314-2979

E-mail: berna@usp.br

DE ACORDO:

Responsável pela Instituição. 